UNIVERSIDADE DE SÃO PAULO

FACULDADE DE FILOSOFIA, LETRAS E CIÊNCIAS HUMANAS

DEPARTAMENTO DE LETRAS MODERNAS

PROGRAMA DE PÓS - GRADUAÇÃO EM LITERATURA BRASILEIRA

\title{
SAGARANA: O BRASIL DE GUIMARÃES ROSA
}

Nildo Maximo Benedetti

Tese apresentada ao Programa de PósGraduação no Departamento de Letras Modernas da Faculdade de Filosofia, Letras e Ciências Humanas da Universidade de São Paulo, para obtenção do título de doutor em Literatura Brasileira

Orientador: Prof. Dr. Luiz Dagobert de Aguirra Roncari

São Paulo 2008 
A

Iran, Clara e Lívia 


\section{MINHA GRATIDÃO}

Ao paciente e competente Prof. Luiz Roncari, pela confiança que em mim depositou.

Aos que me ajudaram a vencer mais esta etapa de vida. 


\section{RESUMO}

O objetivo deste trabalho é o de demonstrar que o conjunto dos nove contos de Sagarana apresenta uma unidade de conteúdo. Desenvolvendo as idéias gerais de Luiz Dagobert de Aguirra Roncari expostas em um curso de pós-graduação ministrado na Universidade de São Paulo (USP) no segundo semestre de 2005, foi possível concluir que uma representação do Brasil da Primeira República constitui o significado central da obra. Esta visão possibilita posicionar Guimarães Rosa entre os intelectuais que se ocuparam de um tema candente na primeira metade do século XX, o de analisar o Brasil com a finalidade de corrigi-lo. Adicionalmente, o trabalho pretende mostrar que a determinação desse significado central é indispensável para a compreensão de Sagarana na sua totalidade.

Palavras-chave: Sagarana, Primeira República, representação do Brasil, poder público e privado, instituições brasileiras.

\section{ABSTRACT}

The objective of this work is to demonstrate that the collection of the nine Sagarana tales has a unified content. The book's central theme is a representation of Brazil during the First Republic. I reached this conclusion after analyzing Luiz Dagobert de Aguirra Roncari's general ideas presented at a graduate course at the Universidade de São Paulo (USP) in the second semester of 2005.

This conclusion places Guimarães Rosa amongst the intellectuals who dealt with the heated issues of the first half of the twentieth century that were focused on studying Brazil with the objective to improving the country. Additionally, this work intends to show that the awareness of that central theme is indispensable for the total comprehension of Sagarana.

Key words: Sagarana, First Republic, representation of Brazil, personal and public power, Brazilian Institutions. 


\section{ÍNDICE}

1. INTRODUÇÃO

\section{DESENVOLVIMENTO}

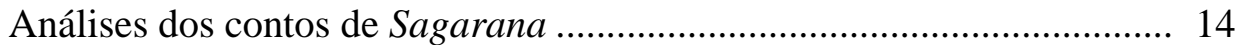

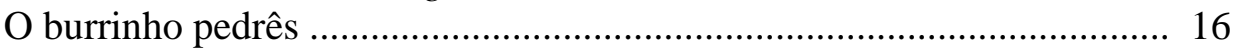

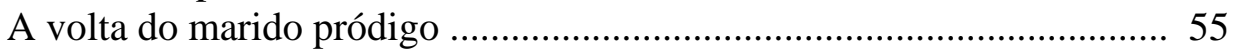

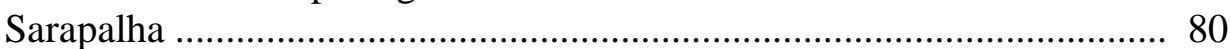

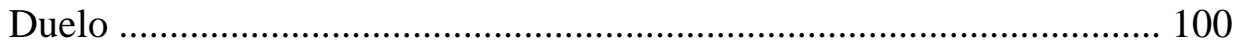

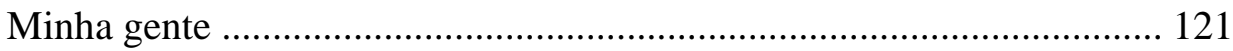

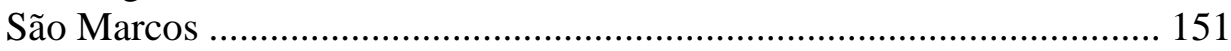

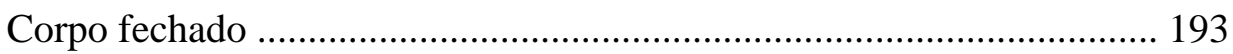

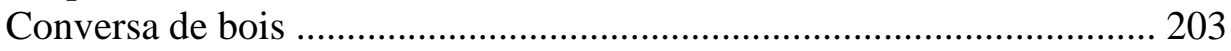

A hora e vez de Augusto Matraga .......................................................... 228

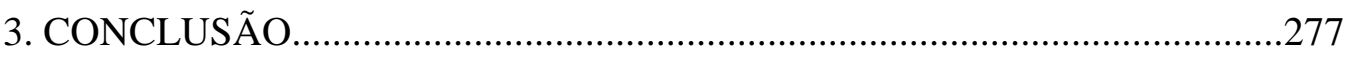

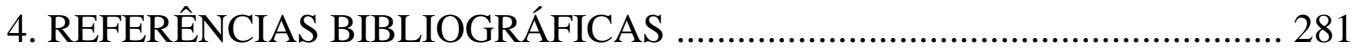




\section{INTRODUÇÃO}

No segundo semestre de 2005, Luiz Dagobert de Aguirra Roncari ministrou na Universidade de São Paulo um curso de pós-graduação que tinha por título $O$ estado da violência e a violência do Estado em dois livros-marcos de Guimarães Rosa: Sagarana e Primeiras estórias. Os dois livros eram tidos por Roncari como pertencentes a duas fases distintas da forma de Guimarães Rosa entender e representar a violência social no Brasil. Sagarana seria a obra inaugural de uma primeira fase que se completaria com Grande sertão: veredas e Corpo de Baile. O curso, embora focalizasse a violência contida nas obras analisadas, tanto no plano da vida privada quanto no da vida políticoinstitucional brasileira, evidenciou que Guimarães Rosa abordou vários aspectos inerentes ao debate que se vinha travando principalmente a partir da década de 20 no meio intelectual brasileiro, no núcleo do qual estava um projeto que tinha por meta analisar o país com a finalidade de corrigi-lo.

O trabalho que estamos propondo é o desenvolvimento das idéias gerais expostas no curso por Roncari. Contudo, como Sagarana e Primeiras Estórias pertencem, conforme se disse, a situações sociais distintas, optamos por restringir nosso estudo à primeira obra.

Os contos de Sagarana possuem algumas características comuns, como linguagem, localização geográfica, temas que se repetem, como o da viagem, e personagens que rebatem em outras - como Manuel Timborna, de Duelo e Conversa de bois. Contudo, os argumentos das nove histórias são diferentes e, à primeira vista, não guardam nenhuma relação de interdependência; igualmente mutável de um conto para outro é a forma da narrativa: o humor do narrador de Duelo pouco tem ver com a seriedade do de A hora e vez de Augusto Matraga, e mesmo as narrativas em primeira pessoa não seguem um padrão regular - casos de Minha gente, São Marcos e Corpo fechado.

O objetivo deste trabalho é propor uma interpretação literária de Sagarana segundo a qual a obra teria um sentido geral, e todas as partes que a compõem estariam intimamente interligadas entre si e a esse sentido nuclear. Para maior rigor metodológico, essa demonstração será desmembrada em duas proposições. A primeira é que as novelas de Sagarana, tomadas em seu conjunto, podem ser coerentemente interpretadas como uma representação do Brasil da Primeira República. A segunda é 
que a determinação da unidade de conteúdo de Sagarana é imprescindível para a compreensão da obra na sua totalidade, e a análise de qualquer um dos contos separadamente, sem uma visada da obra no seu conjunto, corre o risco de cobrir apenas parcialmente os aspectos significativos do livro e do conto focalizado.

Este trabalho procura somar-se à tendência da crítica de analisar a unidade de sentido de cada um dos livros do autor. ${ }^{1}$ A contribuição desse conjunto de trabalhos está em tornar mais articulada a passagem - mediada em maior ou menor grau na obra de Guimarães Rosa - entre a realidade geográfica e humana do sertão e os grandes temas da literatura universal. No meio estaria a representação do Brasil, e é por esse caminho que este trabalho envereda, procedendo à leitura formal dos contos segundo duas orientações: uma analítica, que utiliza referências à cultura literária e filosófica do Ocidente, à mitologia e à psicanálise, e outra que se vale do chamado "pensamento social brasileiro”, que tem em Oliveira Vianna, Paulo Prado, Gilberto Freyre e Sérgio Buarque de Holanda seus representantes mais significativos em Sagarana.

Essas duas totalidades aparecem formalmente distintas no texto rosiano e suscitam questões de ordem geral também diferentes. As referências à cultura literária e filosófica do ocidente aparecem como atualizações, no texto, de um repertório intelectual vasto do autor; de fato, veremos que em Sagarana existem referências a Homero, à Bíblia, a Virgílio, a Dante, a Poe, transfigurados com muita felicidade pela arte particular de Guimarães Rosa. Por outro lado, o que norteia este trabalho é a proposição de que o livro trata do Brasil - que foi colônia no processo de constituição do capitalismo moderno e faz parte do Ocidente e de suas instituições.

De acordo com aquilo que veio a ser conhecido como marxismo "uspiano", o “atraso” do Brasil, grosso modo, é na verdade uma espécie de reprodução perversa do “progresso” dos países centrais, ou seja, nossa “formação incompleta”, notada no texto de Sagarana por meio da forte presença da violência, da ausência de instituições, da baixa coesão social, é, na verdade um produto da reprodução não-linear de uma falsa totalidade, o capitalismo que foi transplantado para o Brasil a partir das idéias liberais inglesas, francesas e americanas do Norte, oriundas do Iluminismo, que transformou as antigas formas de produção e nos fez "desterrados em nossa terra”, como mencionado por Sérgio Buarque de Holanda no período que abre Raízes do Brasil. Como o processo

\footnotetext{
${ }^{1}$ Este e os próximos cinco períodos foram elaborados a partir das considerações de Milton Ohata na ocasião da argüição deste trabalho de doutoramento.
} 
civilizador não se estende linearmente do mesmo modo por todo o planeta, nosso “atraso”, sendo "atraso”, é a conseqüência dos impasses do progresso e, em última análise, do desenvolvimento desigual do capitalismo, cujos efeitos se mostram ainda hoje - “a combinação de latifúndio e trabalho compulsório atravessou impávida a Colônia, Reinados e Regências, Abolição, a Primeira República, e hoje mesmo é matéria de controvérsia e tiros.” (SCHWARZ, 2000, p. 25) -, enquanto a falta de coesão social poderia ser vista como o corolário da contradição entre as idéias racionalistas liberais ocidentais e a instituição verdadeiramente nacional, a escravidão - esta acompanhada da prática do favor que envolvia o latifundiário e seu dependente não escravo -, contradição apontada por Roberto Schwarz:

Em suma, se insistimos no viés que escravismo e favor introduziram nas idéias do tempo, não foi para as descartar, mas para descrevê-las enquanto enviesadas - fora de centro em relação à exigência que elas mesmas propunham, e reconhecivelmente nossas, nessa mesma qualidade. Assim, posto de parte o raciocínio sobre as causas, resta na experiência aquele "desconcerto" que foi o nosso ponto de partida: a sensação que o Brasil dá de dualismo e factício - contrastes rebarbativos, desproporções, disparates, anacronismos, contradições, conciliações e o que for - combinações que o Modernismo, o Tropicalismo e a Economia Política nos ensinaram a considerar. (SCHWARZ, 2000, p. 21).

Pelo que pudemos alcançar, o texto de Sagarana não contém elementos que possibilitem estabelecer o nexo seguro entre a bem-sucedida assimilação das obras de grandes pensadores da humanidade com a problemática assimilação das idéias liberais ocidentais no Brasil. O que nos pareceu mais apropriado - e isto veremos quando analisarmos São Marcos - foi estabelecer as conexões entre o pensamento universal com a cultura popular brasileira e expor a posição de Guimarães Rosa e dos modernistas sobre tais conexões; e que estas carreiam a noção de que no sertão brasileiro as ações intuitivas das personagens e suas formas de integração com o meio reproduzem os arquétipos oriundos das manifestações do pensamento universal.

Na análise de A hora e vez de Augusto Matraga veremos que, como a obra se fecha cronologicamente com a revolução de 1930, não é possível deduzir se o texto sustentaria a asserção de que o governo getulista autoritário seria uma saída para o Brasil ou a de que estamos fadados a permanecer aquém de qualquer processo civilizador nos moldes ocidentais. Para a maior parte dos analistas do Brasil, algo em nossa formação pareceu nos colocar aquém da civilização, ou seja, falta alguma coisa ao país. Essa “falta” ora foi encarada como positiva - pelos modernistas e por Gilberto Freyre, por exemplo -, ora como negativa, casos de Euclides da Cunha e outros; 
Oliveira Vianna, referência importante deste nosso trabalho, como se verá, também pode ser entendido como autor pertencente a esta segunda categoria, porque justifica a necessidade do Estado autoritário com o argumento de que a lógica do poder privado característica da formação brasileira não é capaz de criar uma nação verdadeiramente civilizada. Esse raciocínio esteve presente até recentemente em nosso pensamento social e político, e Oliveira Vianna era “autor de cabeceira” do General Golbery.

Embora os aspectos acima considerados sejam significativos para o enriquecimento da interpretação da obra e da sociedade brasileira, este trabalho não terá por escopo aprofundar-se num estudo sociológico, de acordo com o qual Sagarana seria tomado como fonte para o estabelecimento de leis gerais, isto é, em que a obra seria considerada como a manifestação de leis que lhe são exteriores e que dizem respeito à sociedade (TODOROV, 1976, p. 14). Tal estudo - cujo objetivo seria, primordialmente, a lei sociológica que Sagarana ilustraria - seria de indiscutível interesse, porque poderia dar resposta mais completa do que a apresentada na nossa análise de São Marcos sobre aquilo que a apropriação da cultura universal pode nos dizer sobre o Brasil, além de indicar o que a singularidade sócio-histórica do Brasil, apontada em Sagarana, pode nos dizer sobre a totalidade do capitalismo. Nossa tarefa, no entanto, será menos ampla: dar um passo anterior, contudo essencial, para a compreensão da obra e interpretá-la a partir de indagações sobre o que o texto significa, o que ele nos diz, executando, portanto, uma tarefa que incita à análise hermenêutica; mas, na linha de Culler, ao fazermos uma interpretação nos moldes da hermenêutica, também lançamos questões sobre o funcionamento da literatura, procurando descobrir como é obtido, do ponto de vista da linguagem, o sentido que estamos atribuindo ao texto ou como são obtidos certos efeitos nele presentes (CULLER, 1999, p. 64-6).

Em nossa interpretação, a representação do Brasil levada a efeito em Sagarana é uma elaboração ficcional da realidade, e não um retrato estático e perfeitamente definido do Brasil. Retrato se nos afigura um termo inapropriado para o discurso que podemos visualizar no livro, porque incompatível com suas características: emprego de complicados enigmas, para cuja solução o autor põe ao alcance do leitor apenas vestígios escassos, camuflados e carregados de figuras retóricas; fornecimento de falsas pistas para a solução desses enigmas; insistência eventual em aspectos pouco relevantes e passagem sorrateira pelo que é realmente significativo; emprego simultâneo de recursos populares - linguagem e crenças, por exemplo e eruditos, com aspectos de 
literatura, filosofia, religiões, política, história, etc.; fragmentação da narrativa; liberdade ou flexibilidade do foco narrativo; subversão da linguagem, a ponto tornar a leitura hermética; “A gramática e a chamada filologia ciência lingüística, foram inventadas pelos inimigos da poesia”, diria Rosa (COUTINHO, 1991, p. 71).

Além dos aspectos enumerados acima, caberia acrescentar características discursivas e narrativas sobre as quais discorreremos brevemente. No nível discursivo, a linguagem de Rosa tem forte cunho poético, dotada que é de ritmo e sonoridade peculiar, quando não se serve de recursos métricos tradicionais, que tanto podem mostrar-se nas formas gráficas que usualmente lhes são destinadas quanto entremostrar-se disfarçados no corpo de um texto aparentemente prosaico. Ademais, o texto rosiano lança mão freqüentemente da oposição de planos isotópicos, criando jogos de contradição entre planos de significados opostos, o que faz surgir uma série de figuras de linguagem e pensamento que ora norteiam, ora desnorteiam o leitor. Quando, por exemplo, lemos em A hora e vez de Augusto Matraga que "E assim se passaram pelo menos seis ou seis anos e meio, direitinho deste jeito, sem tirar e nem pôr, sem mentira nenhuma, porque esta aqui é uma estória inventada, e não é um caso acontecido, não senhor” (p. 343) ${ }^{2}$, estamos diante de um jogo de contradição entre planos de significados opostos que equipara o plano de significado "verdade” ao plano de significado "invenção" (= ficção, irrealidade, inverdade). Logo, verdade = inverdade, o que leva o leitor a procurar “corrigir” a contradição através de uma interpretação, introduzindo um recurso típico da poesia e da prosa poética. Em Sezão, versão original de Sagarana, de 1937, a passagem acima era redigida de outra forma: “porque esta não é uma história, mas sim um caso-acontecido, sim senhor.” (ROSA, J. G., 1937, p. 415). ${ }^{3}$ A modificação do texto em Sagarana pode ter sido feita com a intenção de criar uma contradição capaz de aguçar a curiosidade do leitor e levá-lo a pensar nas ambigüidades contidas no texto, nas personagens e na própria natureza da ficção literária.

Por outro lado, no nível narrativo, Rosa lança mão de uma atitude retórica que se aproxima muito da usada na parábola, porque leva o leitor a estabelecer correlações entre um texto "plano”, “chão”, e algum outro tipo de realidade supratextual, por meio

\footnotetext{
${ }^{2}$ Sempre que aludirmos a Sagarana, tomaremos por referência sua $15^{a}$ edição, da Livraria José Olympio Editora, de 1972; somente no caso desta edição adotaremos o procedimento simplificador de manter entre parêntesis apenas o número de página, excluindo, portanto, a citação de autor e data. Com exceção dos nomes próprios, a acentuação ortográfica será sempre atualizada.

${ }^{3}$ Nas citações de Sezão atualizamos a ortografia.
} 
de indícios que vão sendo deixados ao longo do texto. Desse modo, a escrita é, aparentemente, uma seqüência linear, mas que deve ser lida em paralelo com um supratexto; entre ambos, de vez em quando ele traça uma reta que intercomunica os dois planos, mas o desvendamento do nível supratextual fica a cargo da perspicácia do leitor. Assim, como a construção poética, as relações entre o homem e o mundo, o anthropos e o cosmos nem sempre são muito discerníveis, havendo momentos em que um parece reflexo do outro, em que ambos formam uma integridade. ${ }^{4}$ Esta característica narrativa é mostrada de forma menos ou mais acentuada nos contos.

As características formais aqui apontadas levam-nos a pensar que em Sagarana se pode falar em crise do conceito tradicional de representação - que envolveria pressupostos como mimese tradicional e unidade formal. ${ }^{5}$ A representação elaborada por Guimarães Rosa em Sagarana mais sugere do que afirma e, portanto, está muito longe de uma técnica que ofereça a realidade em moldes figurativos muito bem definidos e contornados. Pelas mesmas razões formais, o texto também não tem a conotação científica de um diagnóstico.

Que Sagarana tem uma unidade podemos captar na carta de Guimarães Rosa a João Condé, transcrita nas edições do Sagarana da Editora Nova Fronteira, na qual ele se referia a A hora e vez de Augusto Matraga como uma "História mais séria, de certo modo síntese e chave de todas as outras” (ROSA, J. G., 1984, p. 11). Tal unidade é reforçada em outro trecho da mesma carta, no qual Guimarães Rosa explica por que, na edição de Sagarana, eliminou Bicho mau, uma das doze histórias que compunham Sezão: "Deixou de figurar no "Sagarana”, porque não tem parentesco profundo com as nove histórias deste, com as quais se amadrinhara, apenas por pertencer à mesma época e à mesma zona. Seu sentido é outro.” (ROSA, J. G., 1984, p. 10). Franklin de Oliveira, em A dança das letras, constatou a unidade de Sagarana, afirmando que "cada novela

\footnotetext{
${ }^{4}$ Pensamos que essas considerações são concordantes com as noções de Garbuglio sobre a narrativa de Grande sertão: veredas:

Num ensaio pioneiro e de excelente qualidade como tudo o que realizou, Manuel de Cavalcanti Proença, falando a respeito dos planos narrativos de Grande Sertão: Veredas refere-se à existência dum plano objetivo ao lado dum plano subjetivo, que se discernem e se implicam mutuamente. No plano objetivo transcorrem os acontecimentos e fatos de que participa o narrador. É a história, na terminologia de Emílio Benveniste, a sucessão de fatos em que se envolve a personagem-narrador, como jagunço. No plano subjetivo estão as indagações formuladas pelo personagem-narrador, à busca duma ordenação do mundo para atingir um grau possível de percepção e reconstrução da realidade vivida pelo narrador com incomum intensidade.(GARBUGLIO, 2005, p. 9-10)

${ }^{5}$ Essa observação foi feita pelo Professor Jaime Ginzburg na reunião de 2 de julho de 2007 de análise do Projeto de Qualificação deste trabalho.
} 
deve ser lida como capítulo de um romance, e não apenas tomada isoladamente como história autônoma inserida num livro de contos.” (OLIVEIRA, 1991, p. 57 ) ${ }^{6}$; e Álvaro Lins assim escreveu sobre os contos na ocasião do lançamento do livro:

Cada um deles constitui sem dúvida uma novela independente, com um enredo particular, mas se articulam em bloco como se simbolizassem o panorama de uma região. E Sagarana vem a ser precisamente isto: o retrato físico, psicológico e sociológico de uma região do interior de Minas Gerais, através de histórias, personagens costumes e paisagens, vistos ou recriados sob a forma da arte de ficção. (COUTINHO, 1991, p. 238)

As razões que levaram Guimarães Rosa a retirar de Sezão o conto Bicho mau permitem inferir que todos os contos pertencem a uma época definida, e que, se conseguirmos situar alguns no tempo, todos os demais poderão ser situados no mesmo momento. Como veremos a seguir, esse momento é o da Primeira República.

Minha gente claramente se passa na República Velha, quando o que hoje chamamos de governador era designado por Presidente do Estado: "Política sutilíssima, pois ele faz oposição à Presidência da Câmara no seu Município (n.o 1), ao mesmo tempo que apóia, devotamente, o Presidente do Estado” (p. 188). O mesmo ocorre com A volta do marido pródigo:

Major Anacleto relia - pela vigésima-terceira vez - um telegrama do Compadre Vieira, Prefeito do Município, com transcrições de um outro telegrama, do Secretário do Interior, por sua vez inspirado nas anotações que o Presidente do Estado fizera num anteprimeiro telegrama, de um Ministro conterrâneo. (p. 108).

O burrinho pedrês também pode ser situado na Primeira República porque Badú canta uma dança do tempo da escravatura, que já havia sido abolida quando a passagem ocorre, mas não há muito tempo, pois a personagem é jovem e ainda tem a música na memória: “Ao fim de um tempo, o cavaleiro acordou. Bradou nomes feios, e começou a cantar um ferra-fogo - dança velha, que os negros tinham de entoar em coro, fazendo de orquestra para o baile dos senhores, no tempo da escravidão.” (p. 68).

A hora e vez de Augusto Matraga transcorre pouco antes da revolução de 1930; em Sezão, Joãozinho Bem-Bem afirma: “E agora estou indo para me juntar ao resto do pessoal, porque estão dizendo que vai ter revolução, e compadre Horácio de Mattos é

\footnotetext{
${ }^{6}$ É possível pensar que Guimarães Rosa considerava pertinente essa e outras opiniões de Franklin de Oliveira sobre Sagarana, porque enviou a Harriet de Onís, tradutora americana do livro, um artigo daquele crítico, “As epígrafes”, que, segundo Verlangieri, foi publicado no jornal Correio da Manhã, do Rio de Janeiro, aos 25/10/1958. (VERLANGIERI, 1993, p. 168). Em carta de 09/08/63, a tradutora sugeriu a Rosa que o artigo fosse incorporado como introdução na tradução inglesa e a idéia foi aceita por Rosa em carta de 02/11/63: "Também acho ótima a idéia de tomar para introdução da edição em inglês, o artigo de Franklin de Oliveira - que, realmente, revela o tom de sentido, as tendências do livro.” (IEBUSP).
} 
capaz de precisar de mim...” (ROSA, J. G., 1937, p. 441); em Sagarana, esse período foi substituído por “porque tive recado de que a política se apostemou, do lado de lá das divisas, e estou indo de rota batida para o Pilão Arcado, que o meu amigo Franquilim de Albuquerque é capaz de precisar de mim...” (p. 363). A revolução a que Joãozinho Bem-Bem se refere em Sezão é a 1930, pois Horácio de Matos e Franklin Albuquerque, dois afamados coronéis do sertão da Bahia foram presos após a revolução, e o primeiro foi assassinado em 1931.

Corpo fechado se situa alguns anos depois do episódio de Canudos: "Meu pai viu isso... João Brandão vinha vindo p'ra o norte, com os seus homens, diz-se que ia levando armas p’ra o povo de Antônio Conselheiro.” (p. 259); em Sezão, o Presidente do Estado é também mencionado: “Assinou o telegrama coletivo do Diretório político ao Presidente do Estado, encabeçado pelo coronel Mingote.” (ROSA, J. G., 1937, p. 237).

Os acontecimentos narrados em São Marcos podem ser datados com relativa segurança pela menção da guerra do Paraguai, de 1864-1870, da qual participou Mangolô, que é velho e negro liberto: “João Mangolô velho-de-guerra, voluntário do mato nos tempos do Paraguai, remanescente do "ano da fumaça” (p. 225).

Cassiano, de Duelo era "ex-anspeçada do $1 .^{\circ}$ pelotão da 2.a companhia do $5 .^{\circ}$ Batalhão de Infantaria da Força Pública” (p. 159). A Força Pública do Estado de Minas Gerais foi criada após a proclamação da República, o que nos dá o limite inferior da data em que o conto se desenvolve. Por outro lado, anspeçada era uma patente que no Império se situava entre soldado e cabo e foi extinta ainda no início da Primeira República, mas o termo continuou a ser empregado depois de 1889; em Os sertões, cuja primeira edição é de 1902, lemos: “Afrontou-se com o adversário mais próximo, um anspeçada” (CUNHA, 1940, p. 386). Não podemos, portanto, situar o desenrolar de Duelo exatamente na Primeira República, mas também não existem elementos no conto para supor que ele se desenvolva depois de 1930. Conversa de bois se desenvolve na mesma época, pois nos dois contos está presente a personagem de Manuel Timborna, na página 158 de Duelo e na 287 de Conversa de bois. A maleita no rio Pará torna contemporâneos os acontecimentos narrados em Sarapalha e Duelo: o primeiro se passa “na beira do rio Pará” (p. 119), onde a maleita se abateu sobre as dois protagonistas, e o rio e a maleita são referidos também em Duelo: “- É o Pará... Pois então?!...Mas, vam’ passar p’ra o outro lado, que aqui tá braba a maleita!” (p.175). 
Em vários contos de Sagarana existem outros elementos que poderiam ajudar a reforçar a afirmação de que o livro transcorre naquele período da história do Brasil, como a datação de construção das ferrovias e rodovias, por exemplo, que dariam, em alguns casos, a data mínima em que a narrativa transcorre, mas pensamos que as informações expostas acima sejam suficientes para nosso propósito.

Além do fato de os contos se desenvolverem em um período definido da história do Brasil e da presença dos aspectos formais e temáticos apontados, a unidade de Sagarana se evidencia principalmente em torno de alguns tópicos inerentes à sociedade brasileira que, direta ou indiretamente, eram tratados nas obras dos pensadores que se empenharam em traçar um diagnóstico do Brasil nas quatro décadas iniciais do século XX: a relação entre o exercício do poder privado e do estatal, o nível de coesão social, o predomínio da família patriarcal, a diversidade de práticas religiosas, os traços de caráter como tendência à melancolia, à tristeza e ao romantismo, a prática da violência e as formas de escapar-lhe na ausência de um aparato legal que deveria funcionar acima dos interesses particulares, a formação racial híbrida, o exercício da política partidária, a cordialidade no âmbito das relações na esfera pública, como definida por Holanda etc. Esses tópicos estão distribuídos entre os contos de tal modo que cada um se aprofunda em maior ou menor grau em alguns deles, e nenhum aborda todos ao mesmo tempo em profundidade.

De modo resumido e mencionando apenas os aspectos prioritários, podemos dizer que $O$ burrinho pedrês discorre sobre dois temas principais. Primeiro, as características do que podemos chamar do bom governante, representado pelo Major Saulo, aquele que se empenha em instalar o progresso econômico e a ordem social sem emprego da violência arbitrária. Segundo, as forças que reagem ao progresso: ausência de ânimo empreendedor; saudosismo e propensão ao retrocesso, provocados pela melancolia que anima o brasileiro, apontada por Paulo Prado em Retrato do Brasil; e tendência à violência e à desordem, que, ao que tudo indica, Sagarana sustenta ser imanente no ser humano, que deve ser contida por meio do contrato social. Por tratar das forças que impedem o desenvolvimento e tendem à desordem que se origina da violência, o conto dá descrição pormenorizada do estado de natureza; uma primeira visão sobre o tema das raças na obra também está presente na nossa análise.

Já em $A$ volta do marido pródigo são discutidas a prática da cordialidade brasileira e as formas pelas quais os interesses privados se relacionam dialeticamente com o exercício da política partidária. O conto estabelece uma relação coesa da prática 
política com o amor, casos exemplares das práticas humanas na esfera pública e na esfera privada, respectivamente; a questão racial e as relações familiares de Sagarana são também abordadas na nossa análise do conto.

Sarapalha mostra a desolação de um lugar que teve certo progresso, mas está em ruínas. Ali se vive do passado, de nostalgia, de lembranças; é onde habita e reina soberano o espírito que sintetiza a melancolia brasileira - aspecto desenvolvido por Paulo Prado - e emperra o progresso social e econômico; com ele coexiste a doença, fruto da ausência do poder público protetor. O estado psicológico das personagens, a doença, a tristeza, a saudade e o retrocesso estão de tal forma entrelaçados no conto, que cada um desses fatores é causa e efeito dos demais, e todo o seu conjunto vai gradualmente conduzindo as personagens ao aniquilamento.

Duelo trata da necessidade de o indivíduo arbitrar e fazer valer pela força seu conceito próprio de justiça diante da fraqueza do poder do Estado que deveria ter a função inalienável de arbitrar os conflitos de interesses entre os indivíduos. A escolha de um ex-militar, Cassiano Gomes, como a personagem que imporá sua justiça particular pela violência é sintomática da ausência das instituições oficiais com autoridade para criar leis que imponham limites ao indivíduo e às ações do próprio Estado.

Minha gente desenvolve as idéias que haviam sido expostas em $A$ volta do marido pródigo, porém de maneira mais conceitual. É também abordado neste conto o desdobramento da união marital entre primos, união que assume caráter incestuoso quando tratada como forma do isolamento social ao qual se referiu Freud; como acontece em A volta do marido pródigo, o jogo amoroso se desenvolve paralelamente ao jogo político, e o social determina o conteúdo do conto. Por estar relacionado à discussão de questões teóricas sobre o exercício do poder e sobre isolamento social, que por sua vez se relacionam à formação do Estado, o conto retoma e completa a descrição do estado de natureza de $O$ burrinho pedrês.

Em São Marcos são conceitualmente desenvolvidos alguns tópicos relativos à noção de identidade nacional, por meio da abordagem de temas como religião, amor, literatura e filosofia, a relação do local com o universal e o poder da linguagem.

De certa forma Corpo fechado retoma a discussão iniciada em Duelo sobre a necessidade em que se vê o indivíduo de empregar a violência para defender a própria vida no caso em que as instituições oficiais fracassam nas funções que lhe são pertinentes; e quando até mesmo a alternativa de aplicar a violência em defesa própria 
se torna inviável por qualquer motivo, resta o recurso ao misticismo, condição que configura a forma extrema de abandono do ser humano à própria sorte.

Conversa de bois trata de um tema teórico sobre o estado de direito, o da determinação do limite da vingança justa. O conto mostra ate que ponto a cordialidade pode interferir no juízo que fazemos da violência, induzindo-nos a julgar mais com o sentimento do que com base nas leis que deveriam compor um contrato social.

Finalmente, A hora e vez de Augusto Matraga encerra o livro com a apresentação da saga de uma entidade mitológica tipicamente brasileira, Matraga; essa saga se fecha com a luta apocalíptica do protagonista contra Joãozinho Bem-Bem, mas o apocalipse da saga brasileira não é revestido pela fúria que se verifica entre as entidades mitológicas da saga nórdica, por exemplo, mas ocorre com os dois contendores trocando demonstrações de cordialidade, amizade profunda, prazer no extermínio do outro e na própria morte: é a alegoria da violência no seu estado mais puro e encerra de forma apropriada um livro em que a violência se manifesta do começo ao fim.

A constatação da existência desses motivos espalhados por todos os contos nos levou a concluir que Sagarana é uma obra com um sentido global que só se tornará perceptível se sua análise for levada a efeito com a preocupação de abarcá-lo como um todo. Por essa razão, ao invés de optar pelo emprego do método interpretativo seletivo, que consistiria em concentrar esforços nos contos que julgássemos mais significativos ou em fragmentos de vários contos que pudessem ser tomados como representativos da unidade da obra, optamos pela adoção de um método extensivo, o de partir da interpretação de todos os contos e chegar a um sentido nuclear da obra por aproximações sucessivas.

O critério extensivo apresenta o problema de como enfrentar as passagens subsidiárias não imediatamente conciliáveis com o sentido geral da obra; como afirma Todorov, nem todos os círculos hermenêuticos se equivalem, porque "obrigam a omitir um número maior ou menor de seus elementos.” (TODOROV, 1976, p. 13); Wayne C. Booth, em A Retórica da ficção, afirma que a busca do significado de um romance exprime "a necessidade do leitor de saber onde se encontra na esfera de valores, ou seja, de saber onde o autor quer que ele se encontre.”; e completa:

Mas muitas das obras que valem a pena ler têm tantos "temas possíveis", tantas analogias mitológicas, metafóricas ou simbolicamente possíveis, que encontrar só uma e anunciá-la como objectivo da obra é, na melhor das hipóteses, uma fracção mínima da 
tarefa crítica. O sentido que temos do autor implícito inclui não só os significados que podem ser extraídos como também o conteúdo emocional ou moral de cada parcela de acção e sofrimento de todos os personagens. Inclui, em poucas palavras, a percepção intuitiva de um todo artístico completo; o principal valor para com o qual este autor implícito se comprometeu, independentemente do partido a que pertence na vida real - isto é, o que a forma total exprime. (BOOTH, 1980, p. 91).

As noções de Todorov e Booth, bem como as ambigüidades e contradições inerentes ao texto de Sagarana e a qualquer texto da melhor literatura, acarretam e justificam a sua multiplicidade de leituras. E a idéia de Booth de que emoções do autor implícito, manifestada por meio da individualidade do autor, devem ser consideradas na interpretação da obra para melhor compreendê-la está contida no credo do próprio Guimarães Rosa: “Legítima literatura deve ser vida. Não há nada mais terrível que uma literatura de papel, pois acredito que a literatura só pode nascer da vida, que ela tem de ser a voz daquilo que eu chamo “compromisso do coração”. A literatura tem de ser vida! O escritor deve ser o que ele escreve.” (COUTINHO, 1991, p. 84).

Embora a maior parte do texto de Sagarana nos pareça ter sido coberta por nossa interpretação, de maneira razoavelmente pertinente, algumas passagens, como seria esperado a partir do que dissemos acima, guardam relações imediatas menos evidentes com o sentido nuclear que estamos propondo. Para esses casos adotamos procedimentos que dependem do contexto em que a passagem ocorre: o da figura retórica - somente nas situações que ela se mostrar adequada de maneira convincente -, ou o da formulação de hipóteses de relações sem a força que seria desejável e situadas mais apropriadamente no campo das possibilidades.

O emprego do critério seletivo originaria leituras de interesse sobre vários aspectos importantes - coronelismo, violência, religião, etc. -, mas teria de enfrentar problemas ainda maiores do que os do método extensivo. Em um livro com nove histórias tão diferentes umas das outras, seria necessário orientar as escolhas dos contos ou dos fragmentos que trariam as conclusões que irradiariam para toda obra. Um desses critérios poderia ser o da representatividade do conto na obra, mas teríamos então de especificar com clareza o que nos levou a escolher alguns contos e a abandonar outros. Com o mesmo raciocínio, poderíamos escolher fragmentos do livro para demonstrar nossa interpretação. Mas passagens não analisadas podem conter informações significativas que completem a leitura da obra ou, pior, que a contrarie. A aplicação desse método mais indutivo, tal como empregado por Auerbach de modo tão brilhante em Mimesis, possibilitaria que eliminássemos, se fosse de nosso interesse, as passagens 
que não se conformassem a uma representação do Brasil - o que é, na verdade, o defeito do método e não sua virtude, porque, com uma escolha oportuna, pode-se demonstrar qualquer coisa, sem ter de enfrentar o incômodo de interpretar os motivos subsidiários, as ambigüidades e as contradições de que falamos acima.

O método extensivo, que optamos por empregar neste trabalho, foi o adotado por Luís Bueno para estudar o romance brasileiro da década de 30. A análise da maior parte dos romances daquele período possibilitou ao autor alcançar resultados de qualidade e chegar a conclusões diferentes daqueles que estudaram o período por meio de uma seleção de obras segundo um critério específico (BUENO, 2006).

Alguns autores, dentre eles Walnice Nogueira Galvão (1986), Heloísa Starling (1999), Roncari (2004), e Willi Bolle (2004), associam a obra de Guimarães Rosa a aspectos relativos à sociedade brasileira. Como demonstrou Luís Bueno, Guimarães Rosa não é um demiurgo de si mesmo, “meteoro” caído “sobre nós para extinguir velhos dinossauros e iniciar uma era povoada de outros animais.” (BUENO, 2006, p. 18); pelo contrário, sua obra está posicionada em uma linha de autores dedicados à elaboração de um panorama da sociedade brasileira que se inicia "oficialmente" com A bagaceira e continua nas obras de Graciliano, Jorge Amado e outros da década de 30. Portanto, a afirmativa contida na nossa primeira proposição acima enunciada não constitui exatamente uma novidade, mas necessita de ser demonstrada para a totalidade de Sagarana. 


\section{DESENVOLVIMENTO}

\section{ANÁLISES DOS CONTOS DE SAGARANA}

Nesta segunda parte de nosso trabalho analisaremos os nove contos de Sagarana. Não tivemos a pretensão de fazer uma análise completa de cada conto, visto que, ao longo de seus mais de sessenta anos de vida, a obra já foi objeto de estudo de críticos competentes e perspicazes. Nosso esforço será dirigido para uma missão menos arrojada, a de ressaltar a unidade do livro e a de levantar alguns aspectos que poderão ser úteis a quem, futuramente, se propuser interpretá-lo sob a mesma ótica.

Para Franklin de Oliveira, as duas epígrafes que abrem Sagarana e as que estão presentes nos nove contos são fórmulas algébricas das histórias; sinalizam ao leitor, de forma cifrada e sintética, o que virá no texto, condensando sua dimensão metafísica: “As epígrafes descobrem ou indicam o ideário do autor astuciosamente oculto na trama da narrativa.” (OLIVEIRA, 1991, p. 56).

Ao lado das epígrafes que encimam os contos, há outras, internas ao texto cantigas e toadas, geralmente com função elucidativa e restrita ao âmbito do momento narrado. Encontramos também nos contos de Sagarana muitas histórias e casos que entram na narrativa como historietas autônomas ou noveletas intercaladas no texto, fato que corresponde, como afirma Franklin de Oliveira, à autêntica e velha maneira de narrar. $^{7}$ Algumas vezes elas servem para interligar os contos. Oliveira refere-se ao pretinho de $O$ burrinho pedrês que, de certo modo, se relaciona com o moleque Nicanor, de Minha gente. Essas historietas têm relação com o conteúdo temático da obra e direcionam o leitor na interpretação do texto e, por essa razão, serão sempre analisadas com muita atenção - tarefa em alguns casos complexa e perigosa, porque o caráter freqüentemente figurativo dessas passagens já contém o germe da multiplicidade de leituras e traz o risco da interpretação pouco consistente.

As duas epígrafes que abrem o livro pertencem à categoria das que sintetizam, de modo cifrado, o que acontecerá na obra. A primeira é uma quadra de desafio brasileira,

Lá em cima daquela serra,

passa boi, passa boiada,

\footnotetext{
${ }^{7}$ Guimarães Rosa anotou no seu caderno sobre Homero: “(p. 217 - As longas intercalações/ = maneira autêntica e primitiva de contar)” (IEB-USP, documento E17).
} 
passa gente ruim e boa,

passa a minha namorada.

(quadra de desafio) (p. 2),

e a segunda é a história para meninos da raposa cinzenta:

“For a walk and back again”, said

the fox. "Will you come with me?

I'll take you on my back. For a

Walk and back again.”

(grey Fox, estória para meninos) (p. 2)

A primeira epígrafe refere-se à variedade de personagens que o leitor encontrará no livro, "gente ruim e boa", e assinala o fato de que o foco do livro se encontra no ser humano, com suas paixões, sua larga amplitude de virtudes e defeitos, forças e fraquezas, nobrezas e mesquinharias de caráter e de atitudes. Mas o livro também falará de "minha namorada", do amor, que na obra vai de um extremo - poesia e ternura - ao outro - violência e morte. A epígrafe nos diz que o livro também falará de montanhas; estas, como veremos na análise dos contos, têm função definida na interpretação da obra como ponto de observação mais alto por um olho onipresente e onisciente; como corolário, os atos de subir descer montanhas se tornarão metáforas de amplidão e particularização de ponto de vista, da observação do local e do geral; ao falar de boi e boiada, a epígrafe reforça essa referência ao individual e ao coletivo e, ao mesmo tempo, introduz animais mansos e violentos simultaneamente - mansidão e violência que ilustrarão nas novelas as ações dos humanos em seu grupo social e em sua relação com as próprias forças da natureza. Na segunda epígrafe, uma raposa convida o interlocutor para ser seu companheiro de passeio e retornar ao local de partida. Esta epígrafe tem duplo sentido: por um lado, o narrador, como uma raposa astuta e maliciosa, com um propósito em mente, convida o leitor - e o leva metaforicamente às costas - a realizar uma viagem pelo texto e a decifrar as histórias que, de forma enigmática, lhe serão apresentadas no livro; por outro lado, ela já aponta para o tema da viagem, presente em todos os contos e sobre a qual falaremos na análise de Duelo. O emprego de duas línguas nas epígrafes parece sugerir que o livro não se esgotará na abordagem de temas locais. 


\section{O BURRINHO PEDRÊS}

Após uma epígrafe que analisaremos adiante, o narrador de $O$ burrinho pedrês apresenta a descrição física de Sete-de-Ouros e o relato de sua longa história de vida. A seguir, a narrativa escorrega do olhar do burrinho para a manada. É aí que a violência do mundo animal é descrita pela primeira vez no livro:

De vez em quando, rebenta um tumulto maior.

O pantaneiro mascarado, de embornal branco e quatrólhos, nasceu, há três anos, na campina sem cercas. Não tem marca de ferro, não perdeu a virilidade, e faz menos de seis meses que enxergou gente pela primeira vez. Por isso, pensa que tem direito a mais espaço. Anda à roda e ataca, espetando o touro sertanejo, que encurva o arcabouço de bisonte, franjando um leque de dobras no cachaço, e resolve mudar de vizinhança. Devagar, teimoso, força o caminho, como sabem fazer boamente os bois: põe todo o peso do corpo na frente e nas pontas das hastes, e abre bem o compasso das patas dianteiras, enterradas até aos garrões no chão mole, sustentando a conquista de cada centímetro. O boieco china se espanta, e trepa na garupa do franqueiro, que foge, tentando mergulhar na massa. Um de cernelha corcovada, boi sanga sapininga, se irrita com os grampos que lhe arpoam a barriga, e golpeia com a anca, aos recuões. A vaca bruxa contra - esbarra e passa avante o choque, calcando o focinho no toutiço do mocho. Empinam-se os cangotes, retesam-se os fios dos lombos em sela, espremem-se os quartos musculosos, mocotós derrapam na lama, dansam no ar os perigalhos, o barro espirra, engavetam-se os magotes, se escoram, escouceiam. Acolá, nas cercas - dando de encontro às réguas de landi, às vigas de guarantã e aos esteios de aroeira - carnes quadradas estrondam. E pululam, entre-chocados, emaranhados; os cornos - longos, curtos, rombos, achatados, pontudos como estiletes, arqueados, pendentes, pandos, com uma duas três curvaturas, formando ângulos de todos os graus com os eixos das frontes, mesmo retorcidos para trás que nem chavelhos, mesmo espetados para diante como prêsas de elefante, mas, no mais, erguidos: em meia-lua, em esgalhos de cacto, em barras de cruz, em braços de âncora, em crossas de candelabro, em forquilhas de pau morto, em puãs de caranguejo, em ornatos de satanaz, em liras sem cordas - tudo estralejando que nem um fim de queimada, quando há moitas de taboca fina fazendo ilhas no capinzal.

Agora, se alertam, porque pressentem o corisco. Esperam que a trovoada bata pilão, na grota longe, e então se sobre-chegam e se agitam, recomeçando os espiralados deslocamentos. (p. 6-7)

Na frase "Devagar, teimoso, força o caminho, como sabem fazer boamente os bois”, podemos vislumbrar os dois lados que subsistem conjuntamente, a violência manifesta e a mansidão que pode ser afetiva ou traiçoeira, como será mostrada de 
maneira exemplar na história do boi Calundú contada por Raymundão, da qual nos ocuparemos mais à frente.

A movimentação do gado, em "espiralados deslocamentos” como um rodamoinho, faz de imediato vir à mente que no centro do rodamoinho mora o diabo, como nos diz o subtítulo de Grande sertão: veredas. O rodamoinho será referido também em Minha gente e em outras passagens deste $O$ burrinho pedrês, todas relacionadas ao risco imediato de manifestação da violência: "as vacas, desinquietas, estavam se ajuntando, se amontoando num bolo, empurrando os bezerros para o meio, apertando, todas encalcando, de modo que aquilo tudo, espremido, parecia uma rodeira grande, rodando e ficando cada vez mais pequena, sem parar de rodar..” (p. 27); referindo-se à movimentação do gado inquieto no curral, "Como correntes de oceano, movem-se cordões constantes, rodando remoinhos” (p. 5); quando se trata de um boi perigoso, “- Só ruindade e mais ruindade, de em-desde o redemunho da testa até na volta da pá!” (p. 23); ou quando o gado - tomado pela tristeza ao ouvir o negrinho entoar sua saudosa melodia, no caso contado por Manico - anuncia a violência de que será acometido na sua debandada: “...E, aquilo, logo que ele principiou na toada, eu vi que o gado ia ficando desinquieto, desistindo de querer pastar, todos se mexendo e fazendo redemoinho e berrando feio, quase que do jeito de que boi berra quando vê o sangue morto de outro boi...” (p. 56); o redemoinho acontecerá no córrego da Fome cujo centro é a barriga da cobra, sendo esta um símbolo cristão geralmente associado ao demo -, no momento do afogamento dos vaqueiros: "E ali era a barriga faminta da cobra, comedora de gente; ali onde findavam o fôlego e a força dos cavalos aflitos. Com um rabejo, a corrente entornou a si o pessoal vivo, enrolou-o em suas roscas, espalhou, afundou, afogou e levou.” (p. 66).

Até certo momento da narrativa o gado se movimenta de modo desordenado e essa desordem é indicada na linguagem do narrador: "bicho bronco" “chifre torto”, “desinquieto”, “atropelo estrugente”, “desordena em turbulências”, “aguilhoadas e gritos”. Uma cantiga de amor é então entoada pelos vaqueiros para acalmar o gado:

"O Curvelo vale um conto,

Cordisburgo um conto e cem.

Mas as Lages não têm preço,

Porque lá mora o meu bem...”(p. 23)

Gradualmente ocorre a ordenação do gado, graças principalmente ao conhecimento do Major Saulo e de Zé Grande sobre a forma de lidar com ele e de 
conduzi-lo. A narrativa exprime essa ordenação por várias passagens poéticas. Inicialmente:

Galhudos, gaiolos, estrelos, espácios, combucos, cubetos, lobunos, lompardos, caldeiros, cambraias, chamurros, churriados, corombos, cornetos, bocalvos, borralhos, chumbados, chitados, vareiros, silveiros... E os tocos da testa do mocho macheado, e as armas antigas do boi cornalão...(p. 23).

Mas, ainda que ordenado, o gado se mostra potencialmente agressivo, com "giros estranhos", como em rodamoinho de que falamos acima:

Mas os vaqueiros não esmorecem nos eias e cantigas, porque a boiada ainda tem passagens inquietantes: alarga-se e recomprime-se, sem motivo, e mesmo dentro da multidão movediça há giros estranhos, que não os deslocamentos normais do gado em marcha - quando sempre alguns disputam a colocação na vanguarda, outros procuram o centro, e muitos se deixam levar, empurrados, sobrenadando quase, com os mais fracos rolando para os lados e os mais pesados tardando para trás, no coice da procissão.(p. 23)

A mudança de comportamento do gado, agora ordenado e sob controle, mas ainda assim virtualmente perigoso, continua a ser vivamente expressa nos ritmos poéticos das passagens que se seguem: dezesseis versos falando da tristeza e da saudade do boi, na métrica em redondilho menor - ou oito hendecassílabos. Segue-se uma cantiga de quatro versos em redondilho maior:

As ancas balançam, e as vagas de dorsos, das vacas e touros, batendo com as caudas, mugindo no meio, na massa embolada, com atritos de couros, estralos de guampas, estrondos e baques, e o berro queixoso do gado junqueira, de chifres imensos, com muita tristeza, saudade dos campos, querência dos pastos de lá do sertão...

"Um boi preto, um boi pintado,

cada um tem sua cor.

Cada coração um jeito

de mostrar o seu amor."(p. 23)

Vem a seguir um poema composto por três estrofes de quatro trissílabos cada uma, com tônica na primeira sílaba. O poema lembra, ainda uma vez, que o gado, embora já controlado, permanece uma força agressiva latente; em seguida, outra cantiga de quatro heptassílabos.

Boi bem bravo, bate baixo, bota baba, boi berrando... Dansa doido, dá de duro, dá de dentro, dá direito... Vai, vem, volta, vem na vara, vai não volta, vai varando...

“Todo passarinh' do mato

tem seu pio diferente.

Cantiga de amor doído

não carece ter rompante..” (p. 24) 
Finalmente, a boiada vai caminhando como um navio, ordenada, dominada e disciplinada; O breve trecho, “devagar, mal percebido, vão sugados todos pelo rebanho trovejante (...)" indica o destino dos vaqueiros que serão traiçoeiramente tragados pelo córrego e associa a chuva ao gado, como fará Raymundão mais adiante, quando contará a historio do Calundú; a frase termina com oito trissílabos paroxítonos em ritmo de marcha - um tempo forte um fraco -, paradigma da ordem e da disciplina, seguidos de um tetrassílabo oxítono (se consideramos "no ar" um hiato) que quebra o ritmo da escrita e que fala em chifre, o instrumento de agressão do boi:

E, agora, pronta de todo está ela ficando, cá que cada vaqueiro pega o balanço de busto, sem-querer e imitativo, e que os cavalos gingam bovinamente. Devagar, mal percebido, vão sugados todos pelo rebanho trovejante - pata a pata, casco a casco, soca soca, fasta vento, rola e trota, cabisbaixos, mexe lama, pela estrada, chifres no ar...

A boiada vai, como um navio. (p. 24)

Façamos um comentário sobre o trecho acima transcrito que se inicia com "Galhudos, gaiolos”. Naquela passagem temos uma seqüência de "qualificativos rebuscados”, "referentes a formas ou cores dos bovinos”, conforme afirma o próprio Guimarães Rosa em carta a Harriet de Onís de 11/12/1963:

\begin{abstract}
NOTA - Esses adjetivos, referentes a formas ou cores dos bovinos, são, no texto original, qualificativos rebuscados, que o leitor não conhece, não sabe o que significam. Servem, no texto, só como “substância plástica”, para, enfileirados, darem idéia, obrigatoriamente, do ritmo sonoro de uma boiada em marcha. Por isso, mesmo, escolheram-se, de preferência, termos desconhecidos do leitor; mas referentes aos bois. Tanto seria, com o mesmo efeito, escrever, só la:lalala - la... lá, rá, lá, rá... lá - lá - lá... etc., como quando se solfeja, sem palavras, um trecho de música. Note também como eles se infileiram, dois a dois, ou aliterados, aos pares de consoantes, idênticas, iniciais, ou rimando. (IEB-USP)
\end{abstract}

O "la:lalala - la... lá, rá, lá, rá... lá - lá - lá" só teria plasticidade, só despertaria no leitor a impressão da marcha, caso se concretizasse com qualidades acústicas, ou seja, caso fosse possível perceber tempos fortes e fracos, tal como na execução de um trecho musical, de uma "marcha”, no caso. É por isso que a música ausentada se faz presente por meio da forma poética articulada em palavras, sons, sílabas, como, aliás, desde a Idade Média. ${ }^{8}$ Temos, pois, a música de palavras a plasmar um ritmo. Nesse trecho, a música de palavras prescindiria das qualidades semânticas de seus “dizeres”. Mas as próprias formas poéticas, por si sós, dizem coisas, não são anódinas. A forma escolhida

\footnotetext{
8 “E também os dizeres das canções podem amiúde ser entoados em vários lugares onde são ouvidos de bom grado, onde o canto da música artificial nem sempre teria cabimento, como entre senhores e senhoras em trato particular e secreto" (grifo nosso) (Art de dictier (tomo VII, p. 272), apud POIRION, $\mathrm{D}$, Le poète et le prince).
} 
foi a do redondilho menor, com acento na segunda e na quinta. Um par de redondilhos menores forma um hendecassílabo. Teríamos então:

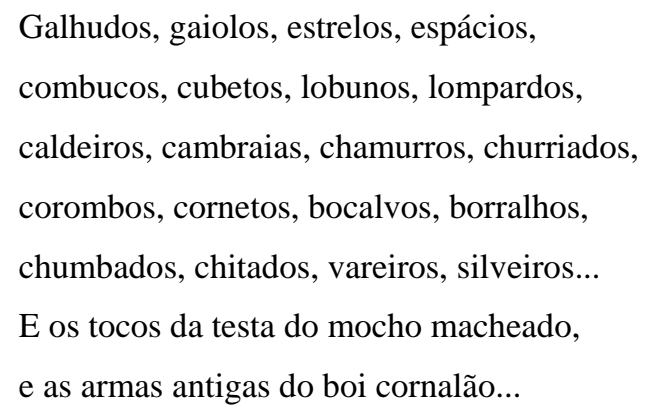

E, se a seqüência dos primeiros cinco versos ainda pode deixar em dúvida quanto à opção pelo redondilho menor ou pelo hendecassílabo, na coerência sintática dos dois últimos versos, "E os tocos da testa do mocho macheado, e as armas antigas do boi cornalão...”, já não nos permite hesitar em optar pelo hendecassílabo. E assim também não restam dúvidas sobre o caráter épico da marcha, pois à batida hendecassilábica obstinada vem se somar um fator semântico surpreendente: “armas antigas”. E aqui não há como deixar de lembrar toda a tradição épica e, em particular, de I- Juca-Pirama, em que Gonçalves Dias circula teimosamente entre essas duas formas, com os efeitos que todos conhecemos.

Em vários contos de Sagarana, principiando por este $O$ burrinho pedrês, se apresentam passagens que ressaltam as manifestações agressivas dos animais, a possibilidade de controle dessa agressividade e o sempre presente risco de retrocesso rumo à selvageria. Essas passagens comportam duas formas de interpretação que se completam: uma literal, quando descrevem a luta selvagem e permanente pela sobrevivência na qual se envolvem homens, animais e plantas e onde imperam a astúcia, a traição e a morte; e uma metafórica, em que aquelas passagens funcionam como figuras da condição do homem em sua "guerra de todos contra todos" e nas quais a identificação figurada entre homens e animais, mais do que meramente fabular, traz implícito o conceito de Hobbes e Freud sobre a maneira violenta que os homens, como os animais, tendem a empregar para resolver seus conflitos de interesses: "É isto que se passa em todo o reino animal, do qual o homem não tem motivo por que se excluir" (FREUD, vol. 22, 1976, p. 246). ${ }^{9}$ Se interpretarmos o comportamento de animais e plantas em Sagarana como figuras do comportamento humano, será possível relacionar

\footnotetext{
${ }^{9}$ Guimarães Rosa refere-se às comparações entre animais e homens feitas na Ilíada: “As comparações com animais já são as preferidas de Homero” (IEB-USP, documento E17).
} 
mansidão e agressividade simultâneas desses seres (como no exemplo do gado e da vaca Açucena, cuja violência se faz sentir na brutalidade das conseqüências para animais ou humanos que se aproximam da cria (p. 8)) com a teoria freudiana dos instintos de vida e morte no homem. Como veremos na análise deste e de outros contos de Sagarana, a noção presente nessas figuras é a de que a natureza só poderá ser benigna para o homem se for conduzida com prudência, conhecimento, cautela e desconfiança, seja pelo afastamento cauteloso, seja pela fuga estratégica ou pela imposição da ordem com sabedoria. Os exemplos de grau variável de adequação de indivíduos às forças da natureza - e, repetindo, o homem faz parte dela - são abundantes em $O$ burrinho pedrês. Tote, por exemplo, sabe como lidar com uma vaca com cria recém-parida e conhece o cuidado que essa operação requer, mas comete o erro de não combinar precisamente com o companheiro Josias a função que caberia a cada um na tarefa de amansar o animal. Esse pequeno erro leva o segundo à morte (p. 19).

A mudança do comportamento do gado, como vimos acima, é obtida pelos vaqueiros com auxílio de três cantigas que têm por tema o amor sob várias formas; interpretada como figura da condição humana, a passagem traduz a noção de que o amor é o sentimento que pode neutralizar a violência intrínseca à natureza. Ou talvez não somente o amor, mas a roupagem poética e musical do amor, já que estas passagens do conto são construídas sobre formas poéticas. Por trás disso tudo talvez esteja a arte poética como protagonista a que se faz alusão, uma arte poética na terceira pessoa, que se esconde mas se entrevê, sobre a qual se fala, mas que não fala.

A narrativa dos eventos subseqüentes ao da ordenação do gado também se refere às manifestações do comportamento de homens e animais. Essa narrativa segue duas linhas paralelas, independentes na aparência, porém intimamente relacionadas: o caso do boi Calundú contado por Raymundão e a caminhada dos vaqueiros e da boiada; o narrador ora se atém a uma, ora a outra dessas linhas narrativas, como num trabalho mental de associação de idéias; a relação entre os dois acontecimentos é, de saída, bem expressa na própria cor de Calundú “- Cor de céu que vem chuva. Berrava rouco, de fazer respeito...” (p. 24). Tal associação ocorrerá varias vezes e é sinalizada ao leitor na forma pela qual Raymundão lembra do Calundú:

\footnotetext{
- Põe p’ra lá, marroeiro!

- Investiu?

- Quase...

- Coisa que ele é acabanado e de cupim, que nem zebu...
} 
- Fosse meu, não ia para o corte. Bonito mesmo, desempenado. Até me lembro do

Calundú. (p. 24).

Associações de idéias ocorrem em várias outras passagens: “De longe, ele já sabia que vinha algum, porque encostava um ouvido no chão, para escutar. Olha, que vamos entrar no cerradão. Tento aí, p’ra eles não se espalharem para os lados!” (p. 25); ou em “- A chuva está aí está caindo, Raymundão. Mas, vigia aquele garrotão preto, que vai ali, babando em cima da casa dos outros. O Calundú era importante assim?” (p. 26). A ambivalência que ocorre na natureza, que ora encanta e ora atraiçoa, é expressa no paralelo criado entre a chuva - que trará a morte aos vaqueiros que a recebem com alegria - e o Calundú, que também trará a morte à criança a ele afeiçoada:

- Espera, olha a chuva descendo o morro. Eh, água do céu para cheirar gostoso,

cheiro de novidade!...É da fina... Mas, então, o Calundú, que era o garrote delas, ainda parecia ser mais graúdo do que era mesmo, rodeando as vacas, meio dando as costas para a manada, assim de cabeça em pé! (p. 27)

Raymundão fala do enfrentamento de uma onça por Calundú e o recuo cauteloso daquela. O que motiva a onça ao ataque é o apetite alimentar, necessário à conservação do indivíduo, e o que motiva o Calundú à defesa é o apetite sexual necessário à conservação da espécie; essa atitude de proteção das vacas por Calundú tem conotação algo similar ao que ocorre no triângulo amoroso composto por Badú, Silvino e a antiga noiva deste, refletindo a luta de machos por fêmeas, motivo persistente em Sagarana. Raymundão, ao contrário de seu interlocutor que supomos ser o vaqueiro Sebastião, conhece a ferocidade da onça, seus costumes e artimanhas, bem como as formas de se defender da fera (p. 28); sabe tratar com os animais e por isso age com acerto no domínio de um boi perigoso, como conta ao Major (p. 40).

A associação de idéias é novamente estabelecida, desta vez entre o medo sentido pela onça frente ao Calundú - medo esperto, pois lhe salva a vida - e a chegada ao córrego da Fome onde, na viagem de volta, Raymundão morrerá, porque não teve nem o medo nem sabedoria da onça diante do perigo do córrego traiçoeiro:

Os homens chegam então no Córrego da Fome:

Depois, correu para longe, sem um miado, e foi-s’ embora. Onça esperta!...

- Oi, que é?

- Estamos chegando no córrego. Vamos lá...(p. 29)

Nesta altura, a narrativa do caso do Calundú é temporariamente interrompido para dar lugar ao episódio da travessia do córrego, que já está cheio nesse momento, e à continuação da marcha. Sebastião e Francolim não demonstram total conhecimento do 
risco que correm na enchente, ao contrário do Major Saulo, cauteloso: “- Bem, mas vamos com paciência! Aqui já tem morrido muita gente...” (p. 30).

Se antes da travessia, a narrativa de Raymundão estabelecia a relação entre violência animal e violência do clima, nesta segunda parte o paralelo se dá entre as forças da natureza animal e humana: à traição do Calundú a Vadico corresponde a traição de Silvino, que estimula um boi a usar sua força para tentar matar Badú. Desta forma, cria-se a aproximação da agressividade do homem à agressividade animal, neste caso motivada por disputa de mulheres. Silvino é chamado de onça-tigre.

Vadico, em sua inocência, acredita entender os animais e em sua bondade perdoa o boi que o feriu. Por sua inexperiência, não entende a fidelidade e a traição ou a brandura e a violência de que, ao mesmo tempo, os bois são capazes: “- Pois eu juro, seô Major, que aquilo foi de supetão... Eu vi o Calundú abaixar a cabeça... Parecia que ele ia querer mais sal... E, aí, de testada e de queixo, ele deu com o menino no chão, do jeito mesmo de que um cachorro derruba uma lata.” (p. 43).

O caso contado por Raymundão é uma explanação minuciosa e repetitiva sobre as relações dos seres no estado de natureza e com as forças da natureza. ${ }^{10} \mathrm{O}$ Calundú, a onça e o homem - os dois últimos sintetizados na figura de Silvino - são ferozes, traiçoeiros e enganadores, como o são o clima e o córrego da Fome; o Major Saulo e o burrinho são as únicas personagens com conhecimento apropriado para enfrentar a natureza com sabedoria. Raymundão, por exemplo, conhece, e muito bem, a natureza de animais, nas engana-se sobre as intenções de Silvino a respeito de Badú, sendo, nesse aspecto o oposto de Francolim, que entende bem os homens e tenta evitar o assassínio de Badú por Silvino.

O caso de Leôncio Madurera é o segundo contado por Raymundão, imediatamente após o do Calundú; a relação entre ambos é imediata e ocasionada pela associação de idéias de Raymundão à frase do Major Saulo sobre o mistério da morte, “- Às vezes vêm coisas dessas, que a gente não sabe, Raymundão.” (p. 44). No entanto, é possível ver uma relação mais estreita entre os dois casos, o da animalização de

\footnotetext{
10 Neste trabalho, quando empregamos a expressão "estado de natureza” estaremos nos referindo ao conceito hobbesiano como exposto por Renato Janine Ribeiro, isto é, a condição do homem civilizado que vive em um meio social onde inexiste o poder do Estado capaz de controlar e disciplinar sua tendência natural ao conflito: "a guerra de todos contra todos (...) não é uma guerra entre seres ainda não socializados. É a degradação completa das relações sociais. (...) O homem natural hobbesiano é integralmente socializado, só que mal socializado.” (NOVAES, 2004, p. 209).
} 
Madurera, um homem sem limites que elimina pessoas para furtar gado, e a humanização do gado furtado - que endereça Madurêra para o inferno como castigo:

Madurêra era um homem herodes, que vendia o gado e depois mandava cercar os boiadeiros na estrada, para matar e tornar a tomar os bois. Pois meu pai contava que, quando ele morreu, e os parentes estavam fazendo quarto ao corpo, as vacas de leite começaram a berrar feio, de repente, no curral. Coisa que o garrote preto urrava:

- Madurêra.... Madurêra!...

E as vacas respondiam, caminhando:

- Foi p’ros infernos!... Foi p’ros infernos!... (p. 44-5).

As idéias até aqui expostas, que, em última instância, implicam discussões em torno do estado de natureza e de fórmulas para escapar da violência a ela inerente, constituem um estrato filosófico moral de $O$ burrinho pedrês. Mas o conto possui também um estrato político evidenciado na personagem do Major Saulo. Ele compreende os homens, os animais, o clima; em suma, compreende, mais do que qualquer um de seus vaqueiros, a natureza em seu sentido mais vasto e sabe como tirar partido dela sem confrontá-la, porque é prudente e paciente. Nessa personagem de próspero proprietário rural e comandante exemplar de um grupo de vaqueiros, consubstancia-se uma visão de bom dirigente do destino dos homens. Nesse aspecto, $O$ burrinho pedrês trata de um tema - muitas vezes e em todos os tempos abordado em livros, artes plásticas e na própria Bíblia - relacionado à determinação dos atributos próprios do governante e às conseqüências (boas ou más) de suas ações sobre aqueles que estão sob o seu comando.

O Major Saulo, apesar de ser a imagem da alegria, "que ria, sempre ria - riso grosso, quando irado; riso fino, quando alegre; e riso mudo, de normal.” (p. 4) -, é temido e respeitado pelo grupo de homens experientes que comanda. O temor e o respeito que o Major provoca em seus auxiliares não decorre de sua violência ou de seu poder de coação econômica - e esta é a visão comunicada pela narrativa -, mas de outros vários fatores, como bravura e coragem, miticamente exageradas pelos seus homens, atributos essenciais no meio; ele "só com o olhar mandava um boi bravo se ir de castigo” (p. 4). Mas, embora corajoso, não é violento (a distinção entre o corajoso e o valentão violento é claramente estipulada em Sagarana: Targino, de Corpo fechado, é violento, mais do que corajoso). Como conseqüência, em seu trato com os homens, não sofre as conseqüências da volatilidade da força de trabalho no Brasil, que se tornou um problema após a abolição da escravatura, à qual, por exemplo, se referiu Caio Prado 
Júnior, em História econômica do Brasil (PRADO JÚNIOR, 1961, p. 220). Sua competência de mando é inquestionável, como se pode deduzir deste diálogo com Manico:

- De nenhum jeito, e eu posso ir junto!... Todo o mundo, aqui, trabalha sem arrocho... Só no falar de obedecer é que todos têm medo do senhor...

- Capaz que seja, Manicão? Será?

- Isso. Uns acham que é porque o seô Major espera boi bravo, a-pé, sem ter vara, só de chicote na mão e soprando no focinho do que vem...

- Mas eu gosto dos bois, Manico, ponho amor neles...

- A pois. Eu sei, de mim, que será por causa de nunca se ter certeza do que é que o meu compadre está pensando ou vai falar, que sai sempre o diverso do que a gente esperou... Só vejo que esse povo vaqueiro todo tem mais medo de um pito do senhor do que da chifrada de um garrote, comparando sem quebrar seu respeito, meu compadre seô Major. (p. 35)

Saulo escuta atentamente o que seus homens falam, pondera e toma decisões acertadas; é este o caso da querela entre Silvino e Badú: levanta as opiniões de Francolim e Raymundão separadamente - conflitantes sobre o tema, estando a razão com Francolim -, habilmente tira de Raymundão as informações de que precisa para concluir que existe o risco de confronto entre os dois homens (p. 45-6). Ao tomar as atitudes necessárias para evitar o confronto (p. 46), atua como instaurador da ordem, impedindo que a violência se instale no grupo. Sabe detectar e trabalhar as virtudes e os defeitos de cada homem, como quando aceita as ponderações do vaqueiro Sebastião e muda sua opinião inicial sobre o local mais apropriado para a travessia do córrego da Fome. De Francolim, aproveita a perspicácia no conhecimento dos homens e a permanente vigilância que exerce sobre eles; por isso, delega-lhe a tarefa de representálo na viagem de retorno, outorgando-lhe a autoridade necessária; e, como Francolim está armado, poderá empregar a violência legítima, em nome do Major, para coibir qualquer ação violenta de Silvino, agindo, portanto, como o Estado ordeiro que utiliza a força legalmente instituída para conter a violência:

- Não adianta bufar que nem tigre, Silvino, que eu estou falando de paz, só na lei, no nome de seu Major!

- Não é caso de briga, Silvino, porque alguma razão Francolim tem.

- Alguma, não! Razão inteira, porque estou representando seu Major, por ordem dele, e meu revólver pode parir cinco filhotes, para mamarem no couro de quem trucar defalso! (p. 62) 
O Major tem a autoridade civil que instaura a ordem para manter a paz e a justiça, Seu ato de conter a agressividade do gado e ordená-lo, juntamente com o grupo de vaqueiros, na saída da Fazenda da Tampa (apresentado de forma tão poética na passagem anteriormente citada), é uma metáfora da sua competência de disciplinar e instituir a ordem, de controlar a natureza agressiva e violenta de seus homens. Ele encarna o chefe de Estado que garante liberdade individual, ao mesmo tempo em que impede que se instaure a lei do mais forte, a lei do valentão - na qual o homem se pauta pela força, pela agressividade. A cantiga da página 49 sintetiza o que sucede no meio social sob a condição de liberdade sem limites:
"Rio Prêto era um negro
que não tinha sujeição.
No gritar da liberdade
o negro deu para valentão...” (p. 49)

Sua liderança é ressaltada quando, no retorno do arraial, já sob o comando de Francolim, começam a surgir a desobediência e a desordem no seio do grupo de vaqueiros:

- É o direito, homem. Eu hoje aqui não sou eu mesmo: estou representando Seu Major...

- Nos cornos! Estou cuspindo nessa bobagem! Não quero prosa com gente pirrônica. Vou com paz, mas vou ligeiro, sem conversa! (p. 49)

- Dou meu voto. Dou meu voto, e estou falando pensado, em visto o dever da continência que eu hoje tenho!

- Tira tua colher do tacho, Francolim! Isto aqui não é hora para palhaçada!

- Respeita o nosso patrão, Sinoca, que seu Major me entregou a responsabilidade dele, para tomar conta e determinar, nos casos...

- Bestagem... O - ô, Badú! Anda, homem!...(p. 61)

- Ei, Silvino, por que é que você está chegando para perto do Badú, aí no escuro, coisa que você não deve de fazer?! Não consinto, não está direito, por causa que vocês estão brigados, e ainda mais agora, que o outro está tão bêbado assim!

- Tu arrepende essa boca, Francolim, filho de outra... Desarreganha, sai por embaixo!... Eu vou aonde eu quero!...(p. 62).

O Major é analfabeto; sua instrução vem da sabedoria dos provérbios - fruto, portanto, da experiência e do senso comum; Padre Vieira, no Sermão XIII, VII, dá aos provérbios o nome de Evangelhos Humanos (VIEIRA, Antônio, 1959, vol IV, tomo XI, p. 278), enquanto no livro da Bíblia que lhes é especialmente dedicado, eles são investidos da autoridade da autoria de Salomão, paradigma do rei sábio. Por empregar provérbios com freqüência, é bem compreendido no meio em que atua; quando, por 
exemplo, percebe que o intuito de Francolim em sua escapadela à cozinha é o de se despedir de Maria Camélia, orienta-o com um provérbio sábio para quem busca parceiro ou parceira: “joá com flor formosa não garante terra boa!” (p. 12). Seu bom senso é intuitivo, não é fruto da razão ou do estudo em escolas. Sabe ver o mundo e, para ele, tudo é muito simples; o acerto nas suas decisões é conseqüência natural de sua prudência:

- Escuta, Manico: é bom a gente ver tudo de longe. Assim como nós dois aqui vamos indo... Pelo rastro, no chão, a gente sabe de muita coisa que com a boiada vai acontecendo. Você também é bom rastreador, eu sei. Olha, o que eu entendo das pessoas, foi com o traquejo dos bois que eu aprendi...(p. 35).

Aqui a sabedoria se manifesta "hermeneuticamente" de duas formas: na primeira, fala-se da visão do geral, de se "ver tudo de longe”, e também dos pormenores, "pelo rastro do chão”, num vaivém do todo ao particular e deste para o todo (o que, segundo Starobinki, tende “a se confundir com o método progressivoregressivo que Sartre, em Questão de método, usou como instrumento da totalidade do saber nas ciências humanas.” (JOUVE, 2002, p. 105)). A segunda manifestação da sabedoria do Major relaciona-se ao seu conhecimento dos homens e dos bois e baseiase nestes para entender os primeiros. Ele sabe que um homem pode transformar-se em bicho a qualquer momento, assim como a mansidão do boi pode ser precursora de ato de extrema violência. Seu conhecimento de homens e animais fá-lo dar o merecido valor a um burrinho que havia sido desprezado pelos homens e até mesmo pelas mulheres da cozinha (p. 37).

Se, por um lado, o Major comanda apropriadamente seus homens e instala a ordem no grupo, por outro ele é um fator de progresso social - como este é entendido na lógica capitalista: traz gado bravo de longe, para engordar e vender, promovendo a integração entre litoral e interior, cuja conseqüência é a construção da ferrovia que entra no arraial; é empreendedor, construiu um patrimônio e acumula riquezas sem parar. Enfim, é um ator de nossa “ordem e progresso”, lema positivista que ele atualiza sem saber; avança quase tão instintivamente quanto os animais, qual paradigma de um país que se constrói sem roteiro e plano, guiado pelos indícios que a natureza lhe dá a ler:

- Pois eu não. Nunca estive em escola, sentado não aprendi nada desta vida. Você sabe que eu não sei. Mas, cada ano que passa, eu vou ganhando mais dinheiro, comprando mais terras, pondo mais bois nas invernadas. Não sei fazer conta de tabuada, tenho até enjôo disso... Nunca assentei o que eu ganho ou o que eu gasto. O dinheiro passa como água no córrego, mas deixa poços cheios, nas beiras. (p. 34) 
É, para seus homens, paradigma de honestidade nos negócios: “- Isto, seu Major. E só gordura honesta de bois. A gente aqui não faz roubo.” (p. 13). Fez-se por si, porque quando moço não tinha título de Major - era "seu Saulinho" - e na Tampa não tinha casa de fazenda: seu patrimônio se resumia em um pasto no brejo e terras no local chamado Retiro, nome que já indica a problemática e desfavorável posição geográfica de suas terras. Acumula corpo, pois havia sido magro quando moço, sendo sua compleição física, presente e passada, metáfora de suas posses.

Manico tem a visão prática do Major Saulo - ele não atravessa o córrego da Fome no retorno na viagem de volta ao arraial -, mas é acomodado, fatalista, quer ficar no lugar:

"Pegamos uma boiada das carepas: só bicho mazelento e feioso: bom quase que nenhum, muito pouco marruaz taludo, tudo com focinho seco, gabarro, com carrapatos de todo tamanho, cheios de bernes e bicheiras, e com cada carne esponjosa de frieira entre as unhas, que era isto:...!....

- Paz para mim! Feito bois sem dono...

- Pois era uma gentinha magra mesmo héctica, tudo meio doente, que eram só se lambendo e coçando jeito de se coçar em cada pé de árvore que encontravam... Mas, para ser bravos, isso eles não estavam doentes, não, que eram só fazendo arrelia e tocaiando para querer matar gente!...

- Boi do mato, sem paciência...

- E ir buscar coisa ruim assim, tão longe!

- Pois foi... Eu cá, por mim, nem que não era capaz de desperdiçar dinheiro meu com aquele refugo de gado. Mas seu Saulinho - seô Major Saulo, pelo direito - sempre foi estúrdio, pensando tudo por regra sua, só dele... (p. 53)

Saulo pode ser assimilado à figura histórica do desbravador, cujo representante mais significativo é o bandeirante, exaltado no início do século XX por vários autores, como Afonso de Taunay, Alfredo Elis Jr, Oliveira Vianna e Cassiano Ricardo. Seu comportamento não guarda nenhuma relação com aquele que Capistrano e outros atribuíram aos bandeirantes, com base em documentos dos jesuítas, o da prática de violência indiscriminada.

As forças do retrocesso que se opõem às do progresso - estas representadas pelo Major Saulo - é mostrada no caso do negrinho. Um fazendeiro que vendeu gado ao Major pediu a este que conduzisse o menino ao Curvelo. Manico relata que o pretinho, saudoso de casa, tentava voltar: "Me deixa eu ir-s’embora para trás! Me deixa eu irs’embora para trás!” (p. 55) e narra a tristeza que se apossa do gado, de sua "querência”, a saudade da terra natal (MARTINS, 2001). Manico fala da tristeza que os vaqueiros 
também passam a sentir, e apenas seu Saulinho havia percebido o risco de o gado retornar e alertava os vaqueiros:

E, aquilo, ele chorava, sem parar, e de um sentir que fazia pena... Não adiantava a gente querer engambelar nem entreter... Eu pelejei, pelejei, todo - o - mundo inventava coisa para poder agradar o desgraçadinho, mas nada d'ele parar de chorar...

- Que inferno!

- E o gado também vinha vindo trotando triste, não querendo vir. Nunca vi gado para ter querência daquele jeito... Cada um caminhava um trecho, virava para trás, e berrava comprido, de vez em quando... Era uma campanha! A qualquer horinha a gente estava vendo que a boiada ia dar a despedida e arribar. E era só seu Saulinho recomendando: “Abre o olho, meu povo, que eles estão com vontade de voltar!” (p. 54-5)

O negrinho entoa uma cantiga que faz que todos os homens, incluindo seu Saulinho, sejam gradualmente tomados de tristeza, saudade, vontade de retorno. A canção exerce um encantamento, é um verdadeiro canto das sereias, episódio no qual até seu Saulinho parece correr perigo, antes que, qual Circe, alerte seus “Ulisses” sobre os riscos e o modo de resistir à sedução:

... E foi aí, bem na hora em que o sol estava sumindo lá pelos campos e matos, que o pretinho começou a cantar...

...Ah, se vocês ouvissem! Que cantiga mais triste, e que voz mais triste de bonita!... Não sei de onde aquele menino foi tirar tanta tristeza, para repartir com a gente... Inda era pior do que o choro de em-antes...

...E, aquilo, logo que ele principiou na toada, eu vi que o gado ia ficando desinquieto, desistindo de querer pastar, todos se mexendo e fazendo redemoinho e berrando feio, quase que do jeito de que boi berra quando vê o sangue morto de outro boi...

...Mas, depois; pararam de berrar, eu acho que para não atrapalhar a cantoria do pretinho. E o pretinho cantava, quase chorando, soluçando mesmo... Era assim uma cantiga sorumbática, desfeliz que nem saudade em coração de gente ruim...

Mas, linda, linda como uma alegria chorando, uma alegria judiada, que ficou triste de repente:

...”Ninguém de mim

ninguém de mim

tem compaixão...”

Aquilo saía gemido e tremido, e vinha bulir com o coração da gente, mas era forte demais. Octaviano pediu a seu Saulinho para mandar o pretinho calar a boca. Mas seu Saulinho tinha tirado da algibeira o retrato da patroa, e ficou espiando, mais as cartas... (...)

... Aí, então, eu comecei a me alembrar de uma porção de coisas, do lugar onde eu nasci, de tudo... (...)

...E o pretinho ia cantando, e, quando ele parava ponto para tomar fôlego, sempre alguma rês urrava ou gemia, parecendo que estavam procurando, todos de cabeça em 
pé...Então, o Binga me disse: - "Repara só, João Manico, como boi aquerenciado não se cansa de sofrer”... (p. 56-7)

O banzo, cantado por vários poetas e ao qual Raimundo Correia dedicou um soneto do mesmo nome, parece estar contido na melancolia do negrinho saudoso de sua terra de origem. Contudo, a história contada por Manico é enriquecida se a interpretarmos como figura do poder das forças de retrocesso: uma frágil criança de sete anos consegue transmitir um sentimento de tristeza e de saudade a um grupo de vaqueiros e a toda uma manada, provocando um efeito devastador ostensivamente exagerado pela descrição dos restos dos dois vaqueiros pisoteados e das precárias condições físicas da porção do gado que conseguiu ser recuperada:

Tinham espandongado por ali a fora, e a gente foi achar uns atolados no brejão, outros de pescoço quebrado, caídos no fundo das pirambeiras, e muitos perdidos no meio do mato, sem nem saber por onde dar volta para acharem o caminho de casa... Outros tinham rolado rio abaixo, para piranha comer. E, os que a gente pode arrebanhar de novo, deram, mal e mal, uma boiadinha chocha, assim de brinquedo, e numa petição - de miséria, que a gente até tinha pena, e dava vontade de se botar a bênção neles e soltar todos no sem-dono! São, são, não tinha quase nenhum... Eram só bois náfegos, vacas descadeiradas, bezerros com torcedura de munheca ou canela partida, garrotes com quebra de palheta ou de anca, o diabo! E muitos desmochados ou de chifre escardado, descascado fundo, dando sangue no sabugo, de tanto bater testada em árvore... Por de longe que a gente olhasse, mesmo o que estava melhorzinho não passava sem ter muito esfolado e muita peladura no corpo... Um prejuizão!...(p. 58-60).

O poder destrutivo da poesia e da música do canto do negrinho é a outra face do poder construtivo da poesia e da música das três cantigas de amor entoadas pelos vaqueiros na saída da Tampa. Tanto em um como no outro caso, poesia e música ocasinam transformação radical, da ordem para a desordem, da desordem para a ordem.

O espírito do Romantismo, traduzido na cantiga nostálgica do negrinho é também tratado na história de boi Calundú:

Eu pernoitei lá, e vi a coisa, seô Major. Ninguém não pôde pegar no sono, enquanto não clareou o dia. O Calundú, aquilo ele berrava um gemido rouco, de fazer piedade e assustar... Uivava até feito cachorro, ou não sei se eram os cachorros também uivando, por causa dele. Leofredo, que era de lá naquele tempo, disse: - “ele está arrependido, por ter matado o menino”... Mas o velho Valô Venâncio, vaqueiro cego que não trabalhava mais, explicou para a gente que era um espírito mau que tinha se entrado no corpo do boi... Parecia que ele queria mesmo era chamar alguma pessoa. Fomos lá todos juntos. Quando ele nos viu, parou de urrar e veio, manso, na beira da cerca...Eu vi o jeito de que ele queria contar alguma coisa, e eu rezava para ele não poder falar... De manhã cedo, no outro dia, ele estava murcho, morto, no meio do curral... (p. 44) 
O Léxico de Guimarães Rosa traz a definição de Valdomiro Silveira do termo "Calundú”: “ente sobrenatural que dirige os destinos humanos e, entrando no corpo de uma pessoa, a torna triste, nostálgica, mal-humorada”. (MARTINS, 2001, p. 94). Não sabemos se Guimarães Rosa conhecia essa definição de Valdomiro Silveira, mas sem dúvida o nome que deu ao boi caracteriza impulsividade e agressividade, conotações que estão em perfeito acordo com os atributos do animal. Roncari definiu a expressão “espírito do Calundú” como a tristeza, a melancolia e a nostalgia que tomam conta do ser humano - a mesma que tomou conta do Calundú - e passa a guiar suas atitudes e pensamentos.

A melancolia e a saudade como características marcantes da personalidade do brasileiro foram apontadas por Paulo Prado em Retrato do Brasil, de 1927, que provocou furiosas críticas dos ufanistas, pelo fato de expor as mazelas do país como resultado de um colonialismo de exploração desregrada. Os primeiros quatro capítulos do livro foram sugestivamente enfeixados em um subtítulo: Ensaio sobre a tristeza brasileira. Segundo Prado, o nosso colonizador português era dominado por dois sentimentos tirânicos, o sensualismo e a paixão do ouro. “A história do Brasil é o desenvolvimento desordenado dessas obsessões subjugando o espírito e o corpo de suas vítimas.” (PRADO, 1999, p. 139). Como fruto das duas obsessões do colonizador luxúria e cobiça - foi criada, ao longo do tempo, uma raça triste: “A melancolia dos abusos venéreos e a melancolia dos que vivem na idéia fixa do enriquecimento - no absorto sem finalidade dessas paixões insaciáveis - são vincos fundos na nossa psique racial.” (PRADO, 1999, p. 140-1).

Não nos interessa aqui trazer as opiniões daqueles que concordam ou dos que discordam de Paulo Prado sobre a origem da tristeza e da melancolia do povo brasileiro, mas o fato é que essas características nacionais têm sido apontadas por vários autores. Para Caio Prado Júnior, por exemplo, “A apatia, Paulo Prado esqueceu-se de a incluir entre os fatores da tristeza brasileira, que não vem somente da luxúria e da cobiça, mas sobretudo de uma inatividade sistemática, que acaba se apoderando do indivíduo todo, tirando lhe até a energia de rir e folgar.” (PRADO JÚNIOR, 1999, p. 349-50); a causa da indolência do brasileiro seria, além do influxo do sangue indígena, o sistema econômico da colônia, com poucas oportunidades e perspectivas. (PRADO JÚNIOR, 1999, p. 349).

Paulo Prado também abordou o "mal romântico", tristeza doentia que se manifestou no início do século XIX, “nesse organismo precocemente depauperado, 
exposto às mais variadas influências mesológicas e étnicas” que é o Brasil. (PRADO, 1999, p. 164). O autor define o Romantismo e discorre sobre ele, referindo-se à sua origem européia e à sua influência na literatura e na política do Brasil. De sua argumentação, interessa-nos o fato de que no Brasil se criou um círculo vicioso no qual a tristeza própria do brasileiro alimentou o romantismo local e este, por seu turno, retroalimentou a nossa tendência à melancolia:

Entre nós o círculo vicioso se fechou numa mútua correspondência de influências: versos tristes, homens tristes; melancolia do povo, melancolia dos poetas. (...).

Morte e amor. Os dois refrãos da poesia brasileira. O desejo de morrer vinha-lhes da desorganização da vontade e da melancolia desiludida dos que sonham com o romanesco na vida de cada dia. E fisicamente fracos pelo gasto da máquina nervosa, numa reação instintiva de vitalidade, procuravam a sobrevivência num erotismo alucinante, quase feminino. Representavam assim a astenia da raça, o vício das nossas origens mestiças.

Viveram tristes, numa terra radiosa. (PRADO, 1999, p. 182-3).

Outros autores se referiram à tristeza como característica do brasileiro. Em Casa grande \& senzala, Gilberto Freyre endossa essa opinião, excluindo, porém, o negro dos portadores desse sentimento de melancolia. (FREYRE, 1989, p. 462).

Sérgio Buarque de Holanda, em Raízes do Brasil, fala do alheamento dos românticos em relação aos fatos sociais, o que, de maneira indireta, significa dizer que o espírito romântico tende ao retrocesso; essa tendência, herdada do colonizador português, ocorre naturalmente: em primeiro lugar, por cultuar a saudade, a nostalgia e, em segundo lugar, por se desligar da vida cotidiana (HOLANDA, 1999, p. 162).

Antonio Cândido, em Formação da literatura brasileira, definiu a sensibilidade romântica: "Na poesia - que é o termômetro mais sensível das tendências literárias - o escritor procura, de um lado, estabelecer para si próprio o estado de solidão; de outro, atrair para ele o leitor.” (CÂNDIDO, 2000, vol II, p. 23).

Mário de Andrade fala da dor como valor dos compositores musicais do Romantismo, vendo-a sob uma perspectiva negativa, dizendo que uma “deformação específica do romantismo foi transformar num repugnante cultivo da dor, a sinceridade com que o povo exprime às claras o sofrimento. Um dos traços essenciais do romantismo é o cultivo da dor”. Ao comparar o Barroco com o Romantismo, ressalta que neste, “toda a gente quer construir uma vida ideal. Ninguém se adapta mais a esta terra, que para os românticos virou um inferno.”. (ANDRADE, M., 1958, p. 128-9). Melancolia, solidão, sofrimento manifestam-se como valores por cultuar, e não como dissabores contra os quais o homem do Romantismo deve lutar. Arnold Hauser, em sua 
História social da arte e da literatura, apresenta uma versão sobre a origem do Romantismo europeu muito útil para nosso contexto. Para Hauser, o sentimento de solidão, desamparo, nostalgia, refúgio no passado e infelicidade que caracterizava o homem do Romantismo era a reação daqueles que, antes da Revolução Francesa, eram prestigiosamente considerados guias das classes progressistas e, depois dela, perderam o prestígio de que haviam antes desfrutado, sendo responsabilizados pelo que a Revolução fizera de mal ou pelo bem que ela deixara de fazer,. Por essa razão, diz Hauser, a maioria deles

\begin{abstract}
viu-se condenada à impotência absoluta e sentiu-se invadida por uma profunda sensação de superficialidade. (...) O sentimento de desamparo e solidão tornou-se a experiência fundamental da nova geração e que influenciou toda sua visão de mundo. Assumiu ela inúmeras formas e encontrou expressão em toda uma série de tentativas de evasão, das quais o retorno ao passado era apenas a mais pronunciada. (Hauser, 2000, p. 672).
\end{abstract}

A associação, que se pode observar no caso contado por Manico, do romantismo com a tendência de retornar ao passado e com sentimentos de tristeza, nostalgia, melancolia, afina-se com tendência referida por Hauser no texto acima. Se levarmos em consideração a ligação estabelecida por Hauser, poderemos estender o conceito de “espírito do Calundú”: ele não só se refere à tendência brasileira à tristeza e à nostalgia, como antes foi dito, mas também sintetiza os mesmos sentimentos do espírito do Romantismo brasileiro, incluindo sua propensão de retorno ao passado - da qual a saudade é o sintoma mais imediato. Logo, esse espírito romântico é assimilado ao regresso, ao retrocesso, próprio naquele que reage às forças do progresso. Ao estabelecer a associação do retrocesso com o espírito do Romantismo - e suas companheiras, a melancolia, a tristeza, a saudade -, o conto mostraria uma relação de causa e efeito duplamente negativa: no campo social, a saudade, a melancolia, a tristeza tornam - se fatores de retrocesso, apatia, inanição e, como vimos no caso do negrinho, de desordem; no campo da arte, esses fatores tendem a promover e perpetuar o espírito do Romantismo, que encontrou solo próprio para criar raízes na tristeza e no saudosismo brasileiros. Contra esse espírito reagiram os movimentos literários pósromânticos, nos quais se inserem os modernistas e Guimarães Rosa e em Sagarana é possível depreender pontos de vista sobre a negatividade do espírito romântico que se afinam com o pensamento de Paulo Prado e de Buarque de Holanda

A respeito dos zebus, diz o sábio Major Saulo: “-É mau, por causa que eles são tristes... Repara, só, no berro que eles têm...” (p. 42). Face a essa afirmação, podemos 
ainda adicionar outro elemento ao "espírito do Calundú”: a prática da violência. O Calundú é nostálgico, melancólico, mas ao mesmo tempo traiçoeiro e agressivo.

E então, em Sagarana, estaria presente um Romantismo malvisto. Por quê? Por cultivar a dor e a melancolia, inerentes a um período definido da história do pensamento da humanidade, como faz Mário de Andrade com respeito à música, por exemplo? Ou por ser o romantismo (agora com minúscula) um aspecto negativo do caráter do brasileiro, como apontado por Paulo Prado e outros? Ou por estar o espírito romântico fora do tempo num Brasil já modernista, em pleno século $\mathrm{XX}$, constituindo, pois, um retrocesso ? $^{11}$ Ou pela soma de tudo isso? Arriscaríamos dizer que vale a combinação das duas últimas condições, pois não nos parece plausível que, para o autor, o Romantismo possa provocar as ruínas que aparecem neste e em outros contos de Sagarana .

A associação direta entre um negrinho, o retrocesso e a canção dos vaqueiros acima transcrita - "Rio Prêto era um negro" etc - não deixa de suscitar algumas reflexões sobre questões raciais; $O$ burrinho pedrês ostentaria um ponto de vista racista que seria reforçado se pensássemos no finório Lalino, o mulato de $A$ volta do marido pródigo e em Mangolô, o negro catimbozeiro de São Marcos. Mas seria imprudente estender a todo o livro o caráter aparentemente racista desses poucos exemplos.

Em Sagarana se encontram vários tipos raciais, como o branco, o negro, o mulato e o caboclo. Portanto, não seria de estranhar que no livro se encontrassem ecos das acaloradas discussões em torno da questão, na época em que Sezão foi escrito. Muitos autores que se ocuparam de formular diagnósticos do Brasil, notadamente nas primeiras quatro décadas do século $\mathrm{XX}$, trataram do tema racial sob vários ângulos e atribuíram a cada uma das raças que configuram a população brasileira pesos e qualidades variáveis na nossa formação social. Nesses estudos, a contribuição do branco tem características sociais geralmente positivas, com algumas variantes sobre os efeitos melhores ou piores da colonização portuguesa. Dessa forma, a discussão em torno das raças se reduz primordialmente aos efeitos, em nossa formação racial, da presença do índio, do negro e de todas as combinações possíveis de mestiçagem entre brancos, índios e negros. Vários intelectuais brasileiros foram influenciados pelo caráter

\footnotetext{
${ }^{11}$ Para nos atermos ainda à música, é fato que compositores importantes “pós - românticos” existiram em boa parte do século XX, tanto aqui como no exterior.
} 
supostamente científico dos estudos étnicos estrangeiros ${ }^{12}$. Euclides da Cunha empregou discursos racistas em Os sertões (CUNHA, 1940, p.108-9); Caio Prado Júnior, sempre sensato em seus juízos, não poupou críticas ao índio e a seus descendentes pela inanição (PRADO JÚNIOR, 1999, p. 349), e o discurso de Oliveira Vianna era abertamente racista, mas, como defensor inflexível do estado de direito, ele não preconizava nenhuma forma de solução da “questão social”; como diz José Murilo de Carvalho sobre Oliveira Vianna, "Racista era quase toda a elite de sua época, embora nem sempre o confessasse.” (BASTOS e MORAES, 1993, p. 14).

Para tentar detectar em Sagarana ecos das polêmicas opiniões acerca das raças, podemos partir de $O$ burrinho pedrês. Nele, encontramos representantes da configuração racial do Brasil: o negro, representado pelo negrinho, pela empregada Maria Camélia e pelo albino Rymundão, “branco de cabelo de negro” (p. 11); o branco, representado pelo Major Saulo: “de botas e esporas, corpulento, quase um obeso, de olhos verdes” (p. 4); e o mulato Francolim. Se tomarmos para análise as figuras do negrinho, do Major e de Francolim, constataremos que têm características pessoais muito diferentes umas das outras: a primeira representa a força do retrocesso e tem, portanto, conotação fortemente negativa sob o ponto de vista social, pois leva à desordem, metaforizada pela morte de dois vaqueiros e da maior parte dos bois. Parodiando o dístico da bandeira nacional, ele personifica “Desordem e Retrocesso”. No outro pólo, o branco Major Saulo, o desbravador que traz “Ordem e Progresso”. Finalmente, temos o mulato Francolim, ajudante fiel do Major, vigilante permanente de tudo o que se passa no grupo, mas que, quando incumbido de dirigir os vaqueiros na viagem de volta à fazenda, se mostra incapaz de conter a desordem que leva ao afogamento coletivo no córrego da Fome. Se nos restringíssemos a esses exemplos, poderíamos concluir que o negro é o retrocesso e a desordem; o branco, o progresso e a ordem; e o mulato serve somente para ser mandado e não para comandar. No entanto, essa conclusão não é confirmada no conjunto do livro, porque nem todos os brancos, negros e mulatos de Sagarana se ajustam ao esquema aqui enunciado. Na verdade, o que se tem nos mulatos Lalino, de A volta do marido pródigo, Gervásio, de Minha gente, Epifânio, de A hora e vez de Augusto Matraga e Francolim, de O burrinho pedrês, é justamente uma grande variação de caracteres. Variação semelhante pode ser observada também em relação aos negros de Sagarana. O albino Raymundão, pacato e

\footnotetext{
${ }^{12}$ A Constituição do Brasil de 1934 estipulava entre as incumbências dos Estados e dos Municípios a de “estimular a educação eugênica”
} 
simpático contador de casos, pouco tem a ver com o negrinho; este, por outro lado, se contrapõe ao astuto e vivaz Moleque Nicanor, de Minha gente; ao feiticeiro Mangolô, de São Marcos, se contrapõem os fervorosos cristãos Quitéria e Serapião, de A hora e vez de Augusto Matraga. São negras as empregadas das casas, como Maria Preta - a “Ceição” - de Sarapalha, Maria Camélia, de O burrinho pedrês, Carmelinda, de Minha gente, nhá Rita Preta, cozinheira do narrador-protagonista de São Marcos. Negros também são alguns trabalhadores braçais, como o preto que "desaferrolha o taipal da traseira, e a terra vai caindo para o barranco”, de A volta do marido pródigo.

No meio social em que Sagarana se desenvolve, o comando pertence aos brancos. Todos os negros e mulatos estão sempre em posição subalterna em relação ao branco. Afora o caso do major Saulo, nada sabemos sobre a cor da pele dos homens de comando que aparecem em Sagarana - Anacleto, Matraga, Consilva, Vilhena, Emílio, e outros -, mas somos intuitivamente levados a considerá-los brancos, salvo citação em contrário.

Embora sejam muitas as passagens de Sagarana em que as personagens emitem juízos depreciativos acerca de negros e mulatos - os comentários do narrador e os de Aurísio Manquitola sobre o negro Mangolô, em São Marcos, ou os juízos do major Anacleto sobre o mulato Lalino, em A volta do marido pródigo, ou os de Manuel Fulô sobre o valentão Miligido e ciganos e judeus, em Corpo Fechado - a grande riqueza das personagens mostra que o livro não sustenta a visão linear segundo a qual as raças teriam relação direta com os problemas nacionais. Tudo parece indicar, ao contrário, que as interações raciais e a (modesta) presença do racismo no livro simbolizam o próprio racismo brasileiro: diluído, disfarçado, verbal, sem a ferocidade e o rancor que se faziam presentes entre as duas guerras mundiais nas democracias e ditaduras de vários países , racismo abertamente declarado por figuras como T. S. Eliot (BAUMAN, 1999, p. 43), H. G. Wells (BAUMAN, 1999, p. 49) e o próprio Winston Churchill (CHOMSKY, 2005, p. 156). No caso do negrinho de $O$ burrinho pedrês, o que nos interessa realmente em sua figura é o efeito negativo do "espírito do Calundú” que ele encarna, espírito ligado à melancolia, que, segundo os pensadores antes referidos, teria, paradoxalmente, origem no branco colonizador português. Entender o negro como sinônimo de atraso pelo fato de uma personagem negra do conto ser metáfora do retrocesso é induzir o que não está texto, pois em outros momentos narrados de Sagarana, negros e negras colaboram com o progresso; o caso do negrinho é mais apropriadamente interpretado se ele representar o legado de retrocesso que a escravidão, 
como fato social e não racial, trouxe ao Brasil. A violência de Sagarana é praticada por todas as categorias raciais, porém com amplo predomínio de parte do branco.

Embora o burro seja um animal geralmente conceituado como símbolo da ignorância, a descrição física de Sete-de-Ouros corresponde à imagem comum de um velho sábio: "E, como os dois cavos sobre as órbitas eram bem um par de óculos puxado para a testa, Sete-de-Ouros parecia ainda mais velho. Velho e sábio.” (p. 4). Segundo Abbagnano, o caráter primordial e fundamental que os epicuristas, os céticos e, sobretudo, os estóicos atribuem ao sábio é o de serenidade ou indiferença em relação às vicissitudes ou aos movimentos humanos, ao que dão o nome de ataraxia, aponia ou apatia. Além dessa, o sábio tem outras características: o isolamento, ou seja, afastamento dos outros mortais, com os quais ele nada tem em comum, e a autarquia, que, segundo Aristóteles, é a capacidade do sábio de ser auto-suficiente em sua contemplação. (ARISTÓTELES, 1973, X, 7, 1177a-1177b, p. 428-9). A renúncia é apontada por Abbagnano como a mais importante característica dos sábios estóicos latinos: o sábio deve renunciar às coisas externas e colocar o bem e o mal unicamente nas que estão em seu poder. Para Plotino, “O sábio extrai de si mesmo aquilo que manifesta aos outros: olha apenas para si: não só tende a unificar-se e a isolar-se das coisas exteriores, mas também está voltado para si e encontra em si todas as coisas.” (ABBAGNANO, 2000, p. 866). Podemos observar em Sete-de-Ouros as características do sábio conforme descritas por Abbagnano: o burrinho “detesta conflitos” (p. 7), procura manter-se à distância dos fatos, dos outros animais e dos homens: "E fechou os olhos. Nada tinha com brigas, ciúmes e amores, e não queria saber coisa a respeito de tamanhas complicações.” (p. 49). "Enfarado de assistir a tais violências, Sete-de-Ouros fecha os olhos.” (p. 7). É imune aos prazeres e às vicissitudes da carne, porque sua atitude é de "estreme alheamento de animal emancipado, de híbrido infecundo, sem sexo e sem amor.” (p. 7), é “Todo calma, renúncia e força não usada.” (p. 7) e a tudo é “mudo e mouco” (p. 33). Mantém total serenidade diante de todos os acontecimentos à sua volta - as manifestações extremas das paixões humanas, bem como as ambíguas atitudes de agressividade e brandura dos animais - ou daqueles nos quais participa diretamente, como a travessia do córrego da Fome: "Só o sério. Sem desperdício, sem desnorteio, cumpridor de obrigação, aproveitava para encher, mais um trecho, a infinda lingüiça da vida” (p. 47). No final do conto, o burrinho se reencontra com sua solidão e com sua serenidade: "Depois procurou um lugar qualquer, e se acomodou para dormir, 
entre a vaca mocha e a vaca malhada, que ruminavam, quase sem bulha, na escuridão.” (p. 68). É observador atento e capta os sinais do mundo predominantemente pelas orelhas, e não pelo olfato, como é regra nos animais, nem pelos olhos, como fazem os homens, pois tem "pálpebras rosadas, quase sempre oclusas, em constante semi-sono" (p. 3). Mostra sua sabedoria na travessia do córrego, e sua atitude paciente difere da adotada pelos homens: enquanto estes, na procura do caminho mais curto e rápido, se locomovem contra a corrente das águas, em um gesto de enfrentamento das forças da natureza, Sete-de-Ouros faz dela sua amiga e nada acompanhando a corrente, utilizando o caminho mais longo e seguro:

E agora os homens e os cavalos nela entravam, outra vez, como cabeças se metendo, uma por uma, na volta de um laço. Eles estavam vindo. O rio ia.

De curto, Sete-de-Ouros perdeu o fundo e rompeu nado; mas já tivera tempo de escolher rumo e fazer parentesco com a torrente. (p. 63)

E Sete-de-Ouros, sem susto a mais, sem hora marcada, soube que ali era o ponto de se entregar, confiado, ao querer da correnteza. Pouco fazia que esta o levasse de viagem, muito para baixo do lugar da travessia. Deixou-se, tomando tragos de ar. Não resistia. (p. 67-8).

Em sua excelente análise de $O$ burrinho pedrês, Franklin de Oliveira fala sobre a mansuetude do burrinho e diz que ele incorpora o tema dos Upanishades,

que é o de uma ciência que assegura a quem a possui uma paz e uma felicidade incomovíveis. Essa ciência consiste no conhecimento da identidade do eu com o ser universal. “Na Índia”, escreve Oldenberg, “o sentimento da personalidade não adquire plena energia; por outra parte não se reconhece aos objetos uma existência sólida e assegurada em limites precisos. A vida não está dominada pela ação que se relaciona com a natureza individual e fixa dos objetos resistentes. Os olhos se cerram às aparências - tratase de ver em suas escuras profundidades a corrente da vida, única em todas as coisas.”(OLIVEIRA, 1991, p. 62)

Franklin de Oliveira põe em destaque a observação de Oldenberg sobre "olhos cerrados” e a expressão "ver em suas escuras profundidades”, assinalando que caminhar no escuro, ser amigo do escuro, são expressões básicas do texto (o Major Saulo diz: “Gosto de caminhar no escuro, João Manico, meu irmão!” (p. 34)). Diz o crítico que, sobretudo em Hawthorne, Poe e Melville, o emprego do escuro na literatura americana vem como símbolo recebido da Bíblia: emblema da queda, das forças demoníacas etc., para então afirmar que "Não é, porém, como tal que o escuro aparece em Sagarana. Ele em Guimarães Rosa simboliza as forças do inconsciente, do instinto, os poderes supralógicos por via dos quais o homem pode mais facilmente chegar ao cerne da vida, 
tocar o centro do universo.” (OLIVEIRA, 1991, p. 63). Lançaremos mão dessas noções nas análises de outros contos do livro.

A paciência e a calma do burrinho são características repisadas no texto. Em Grande sertão: veredas, Riobaldo fala da paciência como atributo de Deus e da pressa como atributo do Diabo: “Deus é paciência. O contrário, é o diabo” (ROSA, J. G., 1956, p. 19). Sete-de-Ouros se humaniza em sua sabedoria e se aproxima do divino por sua paciência. Ele, portanto, alcança a felicidade própria do filósofo contemplativo de quem falava Aristóteles:

Se a felicidade é atividade conforme à virtude, será razoável que ela esteja também em concordância com a mais alta virtude; e essa será a do que existe de melhor em nós. Quer seja a razão, quer alguma outra coisa esse elemento que julgamos ser o nosso dirigente e guia natural, tomando a seu cargo as coisas nobres e divinas, e quer seja ele mesmo divino, quer apenas o elemento mais divino que existe em nós, sua atividade conforme à virtude que lhe é própria será a perfeita felicidade. Que essa atividade é contemplativa, já o dissemos anteriormente. (ARISTÓTELES, 1973, X, 7, 1177a, p. 428)

O burrinho traz, meio apagada, a marca de ferro de "um coração no quarto esquerdo dianteiro" (p. 4):

A marca-de-ferro - um coração no quarto esquerdo dianteiro - estava meio apagada: lembrança dos ciganos, que o tinham raptado e disfarçado, ovantes, para a primeira baldroca de estrada. Mas o roubo só rendera cadeia e pancadas aos pândegos dos ciganos, enquanto Sete-de-Ouros voltara para a Fazenda da Tampa, onde tudo era enorme e despropositado: três mil alqueires de terra, toda em pastos; e o dono, o Major Saulo, de botas e esporas, corpulento, quase um obeso, de olhos verdes, misterioso, que só com o olhar mandava um boi bravo se ir de castigo, e que ria, sempre ria - riso grosso, quando irado; riso fino, quando. alegre; e riso mudo, de normal... (p. 4)

A descrição acima, em um único parágrafo, da marca de ferro no burrinho e de algumas características pessoais do Major, sugere uma quase simbiose entre as duas figuras. Se, como no Ocidente, o coração for considerado a sede dos sentimentos, o fato de a marca estar apagada simbolizaria a ausência atual de afetos no burrinho "sem amor” (p. 7), em oposição à afetividade por seres humanos e animais do major. No entanto, essa comparação fica enriquecida quando se analisa a camada fabular da obra, da qual o burrinho é protagonista. Parece-nos que o narrador estabelece, na travessia do riacho da Fome e no afogamento dos homens, o confronto entre duas formas de sabedoria de dois seres com vasta experiência de vida: de um lado, a do estoicismo do burrinho, na qual não se deve confiar sem cautela, e de outro a do major Saulo, prático e prudente, na qual se pode confiar. Dessa forma, o riacho da Fome pode ser 
compreendido como uma metáfora da vida, segundo a qual, em sua travessia, o homem pode se salvar ou se perder, dependendo de como ele enfrenta a natureza - entendida em seu sentido literal ou metafórico. O sábio Sete-de-Ouros foi um bom guia para si e para os que nele se agarraram. Os homens acreditaram compreender o burrinho e, confiantes, se guiaram por ele, porém foram levados à morte por compreenderem incorretamente sua sabedoria:

- Engraçado?! É mas é muito engano. O burrinho é quem vai resolver: se ele entrar n’água, os cavalos acompanham, e nós podemos seguir sem susto. Burro não se mete em lugar de onde ele não sabe sair!

- É isso! O que o burrinho fizer a gente também faz. (p. 61)

Os vaqueiros sucumbem ao orgulho de não confessarem o medo que a cheia lhes provoca e se lançam em uma operação arriscada de enfrentamento da natureza que lhes tolherá a vida. Salvam-se: Badú, que inconsciente na bebedeira, se faz levar pelo burrinho; Francolim, que consciente e experiente, a certa altura abandona a sua montaria e, sabiamente se agarra ao rabo de Sete-de-Ouros; Juca, que percebendo o risco da empreitada, tem medo e não atravessa o córrego, mas justifica sua recusa alegando um resfriado possivelmente inexistente; e Manico, que não confia no burrinho e também por medo - consciente ou não - vê no pio de corta-pau um aviso ou um indício de mau agouro:

Mas, aí soou o pio, que vinha da moita em cada minuto, justo:

- João, corta pau! João, corta pau!

E João Manico conteve a cavalgadura, e disse:

- Eu não entro! A modo e coisa que esse passarinho ou veio ficar aqui para dar aviso para mim, que também sou João, ou então ele está mas é agourando... Para mim, de noite, tudo quanto há, agoura.

- Perde o medo, Manico! (...)

- Não... Não vou e não vou, de jeito nenhum! Para este poldro me tanger dentro d'água no meio do córrego?... O burrinho é beócio... E não vou mesmo! Não sei nadar...

- Pois, então, eu fico com você, Manico, para lhe fazer companhia...

- Eh, Juca! você não vem? Está com medo também?!

- Medo não, companheiro, dobra a língua! Estou meio ruim, resfriado, e não posso molhar mais o corpo!... (p. 62-3)

Guimarães Rosa definiu, em carta a João Condé, O burrinho pedrês como "Peça não-profana” (ROSA, J. G., 1984, p. 9). Podemos, portanto, supor que o conto contenha um estrato religioso, embora não forçosamente judaico-cristão. 
Em duas passagens, o narrador faz referência ao dilúvio, “- Oh, diabo, custou que melhorou. A gente nem estava podendo tomar fôlego, embaixo desse dilúvio...(p. 28)” e “...- O dilúvio não dava fim. Sete-de-Ouros metia o peito. De enxurro a jorro, o caudal mais raivava, subindo o sobre-rumor” (p. 64), o que poderia levar à formulação de uma interpretação bíblica do conto, uma referência ao episódio de Noé e a arca do livro do Gênesis. Se esta interpretação for viável, o afogamento dos vaqueiros deveria ser um ato de justiça no qual os maus seriam eliminados, e os bons, juntamente com alguns animais escolhidos por Deus, seriam poupados; neste caso, poderia ser considerado que Silvino foi sacrificado por ser mau, e Badú foi salvo por ser bom. Essa interpretação religiosa judaico-cristã do conto não é, entretanto, totalmente satisfatória; em primeiro lugar porque um dilúvio não é exclusivo dessa religião, mas pode também ser encontrado na mitologia grega. (OVÍDIO, 2003, p. 17-20); em segundo lugar, o conto não apresenta elementos interpretativos suficientemente consistentes para se concluir se houve ou não justiça no afogamento. Alguns homens aparentemente bons morrem no acidente e não temos forma de saber se o Major, Manico, Juca, Francolim e Badú são merecedores de melhor sorte do que os que perecem. Uma descrição geral dos oito que se afogarão e das suas respectivas montarias é feita em um parágrafo que parece especialmente destinado a ajudar o leitor na caracterização desses homens:

Voz pomposa, Raymundão, o branco de cabelo de negro: - “Sinoca, larga o que tem dono, que esse coxonilho é o meu!” Com Sinoca, das Taquaras, que já teve pai rico: “Desinvoca, Leofredo, fasta o seu macho para lá!” Daí Leofredo, magrelo, de cara bexiguenta, que se prepara, cantando: - "Eu vou dar a despedida, como deu o bem-te-vi.. .” E Tote, homem sisudo, irmão de Silvino por parte de mãe, puxando o alazão, que não é mau: - “Ara, só, Bastião, com esse arreio de caçambas é que eu não vou, tocando sino de igreja...” Já Silvino, cara má, cuspindo nas mãos para dar um nó no rabo do seu café-comleite de crinas alvas, grande esparramador de lama. E mais Sebastião, o capataz, pulando em cima do Rio-Grande - cavalo de casa, com uma andadura macia de automóvel, tão ligeira que ultrapassa o picado dos outros animais e chega a ser quase um meio-galope. E o bom Zé Grande, mexendo com a boca sem falar, para acabar de enrolar o laço no arção deitado do bastos paulista, e coçando um afago na tábua-do-pescoço do compacto CataBrasa, cavalão herdado, bastardo, pesado de diante como um muar e de cabeça volumosa, mas doutor para conhecer no campo as negaças da rês brava e para se esbarrar para a derrubada, de seda ou de vara. E Benevides já montado - no Cabiúna manteúdo, animal fino, de frente alçada e pescoço leve, que dispensa rabicho mas reclama o peitoral, e é um de estimação, nutrido a lavagens de cozinha e rapadura, o qual não pára um instante a cabeça, porque é o mais bonito de todos, com direito de ser serrador, e está sôfrego por correr; - Benevides, baiano importante, que tem os dentes limados em ponta, e é o único a 
usar roupa de couro de três peças, além do chapelão, que todos têm. Mas Sinoca, novamente, se assentando meio de-banda, por deboche de si mesmo, em cima do AmorPerfeito, palafrém tordilho de Dona Maricota, que estranha o serigote, de tanto afeito ao silhão: - “Cavalo manso de moça só se encosta em tamborete....” - “Ô, gente, Ô gente!” “Desassa a tua mandioca!” E Juca Bananeira, que dá uma palmada na anca do Belmonte cavalo do menino da casa, desbocado, viciado e inventador de modas - e sobe, com excelência, perguntando:

- Eh, e o Badú? Qu’é do Badú?!...(p. 11-2)

Como vemos, a descrição das personagens não segue nenhum critério regular e, portanto, pouco nos auxilia para caracterizar os homens sob o ponto de vista moral; as exceções ficam por conta do “bom Zé Grande” e de Silvino, de “cara má”. Contudo, se a moral foi base de julgamento divino para impor o castigo do afogamento, resulta que acabamos por não ter forma de estimar se a justiça se fez ou não. Porém - e aqui talvez resida o cerne da visão religiosa contida na obra -, é possível que a tese seja justamente a de que aos homens não é dado entender os desígnios de Deus. Esses desígnios podem às vezes parecer injustos aos olhos dos humanos e, desse modo, a compreensão da justiça divina lhes escapa. Cumpre ainda adicionar que o burro, pelo fato de ter servido de montaria a Jesus, tem uma simbologia positiva, porém a simbologia associada ao burro não é essencialmente cristã e nem sempre positiva, como veremos quando analisarmos A hora e vez de Augusto Matraga.

Franklin de Oliveira (OLIVEIRA, 1991, p. 59-60) detecta componentes religiosos no conto, já a partir da sua epígrafe:

"E, ao meu macho rosado,

carregado de algodão,

preguntei: p'ra donde ia?

P'ra rodar no mutirão:”

(VELHA CANTIGA, SOLENE, DA ROÇA.) (p. 3)

Para Franklin de Oliveira, o "macho rosado" desta velha cantiga é o próprio burrinho que dá nome ao conto; a carga de algodão seria o fardo da vida, a carga existencial; o terceiro verso, ao utilizar a forma arcaica do verbo “perguntar” remeteria à constante interrogação dos homens sobre a existência: para quê? por quê? de onde? para onde? E a resposta à pergunta, que vem no quarto verso, significaria, em um nível mais elevado, a submissão ao império do destino. Ele se refere ao burrinho como animal bíblico (OLIVEIRA, 1991, p. 62) para então afirmar - face às referências aos Upanishades que constatou no conto (v. acima) - que: "Eis porque ao burrinho, depois de tê-lo chamado bíblico, chamo-o, agora, de búdico, sem cuidar em sincretismos.” 
(OLIVEIRA, 1991, p. 63), pois tanto o burrinho como o major Saulo "vêem o mundo fluído, diáfano, com aquela indeterminação que caracteriza o pensamento hinduísta.” (OLIVEIRA, 1991, p. 63).

A seguir, Franklin de Oliveira faz referência às citações de Plotino nas epígrafes de Corpo de baile, para afirmar que as idéias daquele filósofo eram estranhas ao helenismo e relacionadas com o pensamento do hinduísmo, para concluir:

Não importa aqui saber se o hinduísmo de que está impregnado o burrinho pedrês - os budistas incluem os animais no mesmo mundo espiritual a que pertence o homem veio através do egípcio helenizado que foi Plotino, como acaso possam indiretamente indicar as epígrafes de Corpo de baile, ou se procedem de fontes diretas. Importa constatar sua presença; e só. (OLIVEIRA, 1991, p. 63).

Com essas considerações, podemos afirmar que o estrato religioso do conto existe, como afirmou o próprio autor na carta a João Condé acima referida, porém ele está mais próximo do hinduísmo do que da tradição judaico-cristã. Talvez esse fato possa ser a explicação plausível da menção de Coromândel e Travancor (p. 6), que funcionaria como um lembrete ao leitor de que procure encontrar alguma referência à Índia no conto.

O tratamento simultâneo, em $O$ burrinho pedrês, da violência na natureza incluindo nesta os próprios seres humanos - e dos atributos dos homens de comando que, de uma forma ou de outra, são patrocinadores de um contrato social tácito -, levantam a possibilidade interpretativa de que um dos temas centrais do conto seja o da necessidade de neutralizar a agressividade nas relações sociais por meio do contrato social

A violência é recorrente em Sagarana. De fato, nos nove contos existe sua ameaça ou sua prática efetiva por uma ou mais personagens. Ela é cometida por uma criança, o Tiãozinho de Conversa de bois, ou por adultos, geralmente do sexo masculino. Silivana, dependendo da interpretação que dermos ao desfecho de Duelo, pode ser a única a fugir dessa regra, porque as mulheres em Sagarana são primordialmente envolvidas em questões amorosas de diversas naturezas. Ao atribuir a violência aos homens, Sagarana conserva a noção de Pierre Clastres exposta em Arqueologia da violência, de que a divisão sexual das tarefas na comunidade primitiva faz da atividade guerreira uma função masculina e a reprodução biológica da 
comunidade uma propriedade essencial das mulheres e, portanto, o homem é ser para a morte e a mulher é ser para a vida. (CLASTRES, 2004, p. 309-10).

Ao ambientar Sagarana na época da Primeira República, Guimarães Rosa não criou tempos e lugares ideais para a construção de sua ficção; usando tempos e lugares reais, carreou para a sua ficção usos, costumes, marcas características desses tempos e lugares, usando tais elementos como matéria-prima e modificando-os o suficiente para a elaboração ficcional, mas não a ponto de torná-los indistinguíveis. Um dos aspectos que mais marcam o período é a violência, que foi recrudescida na cidade e, de forma mais cruenta, no campo; este foi palco de lutas de todas as espécies, entre os quais as de famílias, num cenário que se deveu em grande parte à atuação de coronéis detentores do poder econômico e político, lutas que, com freqüência, chegaram a se estender a centros populosos, como Lençóis e Salvador.

Essa realidade se mostra ou entremostra em Sagarana. O Estado está ausente como mantenedor da ordem. A figura do presidente da República não é nomeada uma única vez, e a do presidente de Estado o é por três vezes: em duas passagens de Minha gente (p. 188 e p. 221) e em uma de A volta do marido pródigo (p. 108); nesta, a figura do Presidente do Estado é relacionada a uma burocracia que emperra o funcionamento fluente das relações sociais e nada mais é do que uma peça da máquina que movimenta o complexo jogo da política que se retroalimenta como um fim em si mesma. Como os dois contos se desenrolam em período prévio às eleições locais, podemos inferir que a presidência do Estado só se apresenta em período eleitoral, estando totalmente ausente em outras situações. As figuras dos mantenedores da ordem - policiais, delegados - são tão omissos em suas funções quanto as autoridades administrativas. Quando, em Corpo fechado, Manuel Fulô procura a polícia para protegê-lo de Targino, fica sabendo que o sub-delegado escapulira com medo do valentão. Em Duelo, a personagem de Cassiano Gomes, um ex-policial, é possivelmente a figura mais violenta de Sagarana, como mostraremos quando analisarmos aquele conto. E em Minha gente lemos que "Tio Emílio pediu-me que redigisse um telegrama ao Secretário do Interior, solicitando a substituição do comandante do destacamento policial da vila, que, por sinal, já foi cambiado duas vezes, nestes seis meses derradeiros.” (p. 190), passagem que permite deduzir, entre outras coisas, que é nula a capacidade de repressão de uma autoridade policial sobre os detentores do poder local, uma vez que estes têm influência direta no destino daquela. 
Se partirmos das idéias dos pensadores que - como Thomas Hobbes, Sigmund Freud, Pierre Clastres, René Girard, Anthony Storr e outros - sustentam a noção de que a violência deve ser contida por meio do contrato social, por ser imanente no ser humano - conceito que se opõe a outro, segundo o qual a violência seria fruto exclusivo das condições sociais nas quais ela se manifesta -, numa primeira aproximação, seria possível dizer que a ausência, no texto de Sagarana, de qualquer referência à fome e à miséria, por exemplo, exclui a possibilidade de ver em motivos econômicos a causa direta da violência: os pobres não passam por necessidades de bens materiais, e os proprietários rurais, por seu turno, são comedidos na exibição do seu poder financeiro (com a exceção de Nhô Augusto que, para esconder sua atual condição econômica precária, arremata a prostituta Sariema em um leilão por dez vezes o maior lanço).

Parece-nos acertado afirmar que em Sagarana o fator propiciador imediato da violência é a fraqueza do Estado de direito; sua ausência funcionaria então como catalisador para a manifestação de um instinto agressivo que, na fragilidade do contrato social, tenderia a provocar a instintiva "guerra de todos contra todos". Porém, a fraqueza do Estado está intimamente relacionada com o exagerado poder privado durante a Primeira República, cuja origem estava na descentralização a serviço de objetivos políticos e, na sua essência, econômicos. Mas pode dar-se também que o atendimento a objetivos políticos e a ausência do Estado tenham origem em causas ainda mais remotas, como fragilidade da coesão social, fragilidade de instituições e falta de hierarquia organizada, que Sérgio Buarque de Holanda, no capítulo Fronteiras da Europa de seu Raízes do Brasil, afirma serem originadas de um traço historicamente mais decisivo da gente da Península Ibérica, o de cultura da personalidade, e que, portanto, no Brasil, “A sociedade foi mal formada nesta terra desde as suas raízes.” (HOLANDA, 1999, p. 181); a mesma baixa coesão social brasileira foi apontada por Caio Prado Júnior, em Formação do Brasil contemporâneo (PRADO JÚNIOR, 1999, p. 345). Pensando desse modo, a baixa coesão social inerente à nossa formação constitui solo fértil para a disseminação do exacerbado poder privado daquele período histórico, ou seja, o poder privado é endossado e validado pelo contexto social; de fato, Sagarana espelha a fraqueza da coesão social apontada por Holanda: as relações familiares são frágeis, as práticas religiosas congregacionais são reduzidas, a prática da violência se torna comum; falta de coesão social e fragilidade das instituições são conseqüências da exaltação dos valores cordiais, da cordialidade como ele a definiu. Daí resultaria a relutância do brasileiro em aceitar um princípio supra-individual de organização e o 
fato de sua conduta evidenciar, com freqüência, apego aos valores da personalidade configurada pelo recinto doméstico. Este traço de personalidade explica - ou, pelo menos, denuncia - a impossibilidade de instauração do império da lei, uma vez que a personalidade individual sempre será avessa a suportar o comando de um sistema exigente e disciplinador: “A idéia de uma espécie de entidade imaterial e impessoal, pairando sobre os indivíduos e presidindo os seus destinos, é dificilmente inteligível para os povos da América Latina.” (HOLANDA, 1999, p. 183). Ao escrever sobre as possibilidades de modificações - ou correções - da nossa sociedade, no capítulo Nossa Revolução, Holanda fala da resistência que uma transformação profunda encontraria na mentalidade personalista que caracteriza o americano do sul:

As constituições feitas para não serem cumpridas, as leis existentes para serem violadas, tudo em proveito de indivíduos e oligarquias, são fenômeno corrente em toda a história da América do Sul. É em vão que os políticos imaginam interessar-se mais pelos princípios do que pelos homens: seus próprios atos representam o desmentido flagrante dessa pretensão. (HOLANDA, 1999, p. 155).

Essa visão desanimadora sobre a política é endossada por Oliveira Vianna, para quem os partidos no Brasil são fórmulas de solidariedade encontradas pelos políticos para defesa de seus interesses privados (VIANNA, 1991, p. 275). Em Sagarana a cordialidade praticada pelos políticos brasileiros, em suas várias formas e diversos objetivos (nos moldes apontados por Holanda e Oliveira Vianna), será evidenciada nos dois contos que narram períodos eleitorais: Minha gente e $A$ volta do marido pródigo. Os indivíduos envolvidos na política - Anacleto, Laudônio, Lalino, Oscar, Emílio - não emitem um só discurso, uma única frase, que demonstre o mínimo de interesse público ao longo de toda a obra.

Acreditamos que em Sagarana a baixa coesão, a cordialidade e a política egoísta possam ser apontadas como causas e, ao mesmo tempo, conseqüências naturais de um contrato social rescindido unilateralmente e, portanto, impróprio para organizar a vida coletiva, porque permite a cada pessoa atuar em sociedade como um ser individualizado que tem o arbítrio de cumprir ou não suas obrigações com a comunidade de convívio, não se estabelecendo, assim, a distinção nítida entre a liberdade na esfera pública e a liberdade na esfera privada. A violência em Sagarana parece decorrer, portanto, da precariedade de um contrato cuja fragilidade estaria ligada à baixa coesão social que, por sua vez, estaria relacionada ao exorbitante poder privado das oligarquias. Para Holanda, no entanto, a baixa coesão social é a conseqüência do processo de colonização 
brasileiro, e não uma característica exclusiva da Primeira República; salvo lapso de nossa parte, a assertiva de Holanda não contraria os elementos presentes em Sagarana, porque não exclui a possibilidade de que a coesão social possa declinar nas situações em que inexistam instituições capazes de conter seus sintomas, principalmente a violência.

Na forma sistêmica como Sagarana trata do fenômeno da violência, abarcando aspectos sociais e psicológicos simultaneamente, parece-nos detectável o propósito de enfrentar um tema de enorme complexidade, mostrando o entrelaçamento de um conjunto de causas imediatas e remotas somente evidenciado quando fatores como família, religião, cordialidade, política são considerados de forma sistêmica na totalidade do livro. A ausência de instituições faz emergir simultaneamente a violência e o exorbitante poder arbitrário privado; mas este último, por seu turno, embora apoiado em bases econômicas - não explicitadas na obra -, é endossado pela baixa coesão social - esta, de fato, tão evidente no texto rosiano quanto a própria violência. A ausência, na trama, de mazelas como miséria, desemprego, fome e precárias condições de sobrevivência talvez tenham o propósito de evitar qualquer conjectura simplista que pudesse induzir a atribuir a origem da violência direta e exclusivamente a motivações político-econômicas. Nesse sentido, a terapêutica social implicitamente sugerida seria a do fortalecimento das instituições oficiais.

A hipótese de que, em Sagarana, a violência tem origem na ausência de um Estado com poder legítimo para contê-la é francamente perceptível. No texto não é difícil identificar idéias que Thomas Hobbes não renegaria. Nesse sentido, Guimarães Rosa foi generosamente redundante, porque muitas são as passagens em que o estado de natureza e o permanente risco de o homem se converter em fera e resolver suas divergências descambando para a violência estão presentes nos fatos narrados. Há vários outros aspectos em que as idéias de Hobbes se aplicariam a Sagarana. O Major Saulo exerce poder absoluto e inquestionável sobre os seus comandados e, com sua permanência no arraial, o grupo de vaqueiros na viagem de volta não reconhece totalmente a autoridade que o Major delegara a Francolim; com a perda do comandante, os homens se igualam, e ocorre a tragédia do afogamento, como que a lembrar o conceito hobbesiano de que a igualdade mantém os homens em estado de guerra, de que a paz somente pode ser alcançada com o poder e com a desigualdade, e que o advento do Estado, ao instalar a desigualdade, impede a perpétua insegurança das relações de poder (RIBEIRO, 2003, p. 30). 
As considerações acima sobre, de um lado, as manifestações do estado de natureza e de violência e, de outro, a presença de personagens que representam o progresso e outras que reproduzem a estagnação e o retrocesso, sugerem a possibilidade de se interpretar $O$ burrinho pedrês como uma alegoria sobre o processo civilizador e a formação do Estado. Um propósito desse tipo estaria harmonizado com os debates que se travavam no meio intelectual brasileiro nas primeiras décadas do século XX e implicaria a discussão em torno do tema “civilização”. Um exame dessa possibilidade interpretativa, contudo, exige que se defina o que em Sagarana se entende por civilização. Como o conceito é objeto de múltiplas definições, lançaremos mão das idéias de Francis Wolf expostas no ensaio “Quem é bárbaro?”, no livro Civilização e barbárie.

Wolf faz alusão a três sentidos do termo “civilização”. No primeiro, civilizados seriam os que se comportam com boas maneiras, vestem-se adequadamente - portanto, não vivem quase nus nas selvas, como os selvagens -, cumprem com refinamento e delicadeza suas funções físicas naturais, são polidos no trato com os outros, têm bons modos à mesa, etc. No segundo sentido, o nível de civilização seria mensurado pelo patrimônio nos campos da filosofia, da literatura, da poesia, da música erudita, das artes, etc; neste segundo sentido, seriam bárbaros os insensíveis ou os que não compreendem o valor do patrimônio da vida espiritual humana, porque só reconhecem valor no que é útil, no que satisfaz as necessidades vitais, no que traz prazeres grosseiros. O terceiro sentido de civilização "pressupõe respeito pelo outro, assistência, cooperação, compaixão, conciliação e pacificação das relações - em oposição ao que se supõe natural ou bestial, a uma violência vista como primitiva ou arcaica, a uma luta impiedosa pela vida" (NOVAES, 2004, p. 22). Neste terceiro sentido, "barbárie” significa desumanidade e engloba toda sorte de fenômenos destruidores, como campos de extermínio, genocídios, etnocídios, perda de qualquer sentimento humanitário como compaixão pelo mais fraco, benevolência, tolerância. Wolf pergunta se existe uma ligação entre os três sentidos, e responde que “Com efeito, é possível demonstrar que os comportamentos mais bárbaros, no terceiro sentido - ou seja, comportamentos selvagens e sanguinários - são muitas vezes atos de homens, sociedades e culturas que são - ou se consideram - os mais civilizados no primeiro e no segundo sentidos”. (NOVAES, 2004, p. 27); como exemplo, Wolf menciona os gregos, que praticavam a escravatura, a Alemanha nazista e os conquistadores, concluindo que o terceiro sentido é o único aceitável quando se fala em barbárie e civilização: 
Chamaremos de bárbara toda cultura que não disponha, em seu próprio cerne, de estruturas que lhe permitam admitir, assimilar ou reconhecer outra cultura - ou seja, a simples possibilidade de outra forma de humanidade. Também chamaremos de bárbaro, conseqüentemente, todo costume ou toda prática que, qualquer que seja a cultura específica a que pertença, tem como finalidade ou efeito negar uma forma específica de existência humana. É o que nos permite compreender, a partir de agora, a ligação entre esse sentido “formal” da barbárie e o conteúdo que lhe demos inicialmente, o terceiro sentido, o único que mantivemos (NOVAES, 2004, p. 41).

Essas idéias de Francis Wolf nos auxiliarão a formular uma hipótese sobre o que se entende por civilização em Sagarana. Os primeiros dois sentidos do termo não se apresentam no livro. Não existe no texto o contraste ostensivo entre bons e maus costumes que seria empregado pelo narrador para caracterizar o primeiro sentido. Por outro lado, a cultura erudita de algumas personagens, característica do segundo sentido, não é exaltada em comparação à ignorância de outras personagens; pelo contrário, o leitor é induzido a simpatizar mais com o humanismo do analfabeto Major Saulo de $O$ burrinho pedrês, do carreiro João Bala de Conversa de bois ou do fiel Quim Recadeiro de A hora e vez de Augusto Matraga, do que com a erudição dos intelectuais do livro como, por exemplo, os narradores de Minha gente e de Corpo fechado ou o protagonista de São Marcos.

O terceiro sentido de civilização definido por Wolf pode ser ajustado, com boa aproximação, aos conceitos de civilização e barbárie evidenciados em Sagarana. Por um lado, o texto rosiano é um desfile contínuo de personagens que instalam a desordem, que têm a intenção de praticar ou afetivamente consumam a violência e a brutalidade; desordem, violência, brutalidade, já o dissemos, são abundantemente expostas no texto, de modo literal ou simbolizadas de várias formas; por outro lado, homens - literal ou metaforicamente assimilados a animais e plantas - tentam de vários modos livrar-se da violência que os ameaça ou que efetivamente os atinge. Essas condições sociais, que se apresentam no livro como regra e não como exceção, são as que caracterizam o estado de barbárie. O fato de o momento histórico focalizado ser o do predomínio das oligarquias - no qual a violência generalizada envolveu governo, políticos, proprietários rurais, cangaceiros e jagunços em relações complexas, em quase todas as combinações teoricamente possíveis de confrontos e alianças, além de fanáticos religiosos e a própria Igreja Católica - possibilita ver Sagarana como um complexo arcabouço narrativo no qual o predomínio do poder arbitrário nas relações políticas favorece o estado de barbárie. De fato, no texto há momentos em que a presença de instituições sólidas leva 
à obtenção de segurança e paz social; por exemplo, a chegada de um destacamento policial a Laginha, onde se desenrola Corpo fechado, encerra uma história de consecutivos valentões locais (p. 286), e é por meio da alusão da possível intervenção do governo que o astuto Lalino, de $A$ volta do marido pródigo, soluciona uma antiga contenda entre Antenor e Martinho (p. 105). Contudo, essas soluções são civilizadoras somente na aparência, porque contêm o outro lado da violência, a do Estado truculento que reprimiu brutalmente os movimentos de Canudos, Contestado e o Caldeirão do Beato Lourenço, aliando-se ao cangaço quando necessário, como sucedeu na passagem da Coluna Prestes pelo Nordeste em 1926, para o combate da qual Lampião recebeu do Governo a patente de capitão honorário das forças legais, além de doação de armamento e munição. A brutalidade do Estado tem presença discreta em Sagarana, mas o exemplo marcante é a personagem de Cassiano Gomes, de Duelo.

Na definição de barbárie dada por Wolf, acima transcrita, está implícita a noção de que a "civilização vive a inversão em seu próprio interior, isto é, traz em si mesma a possibilidade de retorno da barbárie” (NOVAES, 2004, p. 10), noção que pode ter sido comprovada por Guimarães Rosa na prática, pela vivência do período histórico que antecedeu a segunda guerra mundial e por sua condição de diplomata na Alemanha nazista durante a guerra. E é possível encontrá-la em Sagarana, como dissemos quando analisamos o episódio da ordenação do gado na saída da Tampa.

O que podemos concluir, a partir dessas considerações, é que em Sagarana o conceito de civilização está diretamente associado à criação de um conjunto de atividades e instituições capazes de conter a violência - esta apresentada como algo imanente no ser humano, o que conflui para aquilo que Freud diz em $O$ mal estar da civilização: “A substituição do poder do indivíduo pelo poder de uma comunidade constitui o passo decisivo da civilização.” (FREUD, 1974, vol. 21, p. 115-6).

A personagem do Major Saulo no conto é positiva, portanto oposta à representação negativa do coronel na literatura da época em que foram escritos Sezão e Sagarana - como, por exemplo, Paulo Honório, de São Bernardo. O narrador de $O$ Burrinho pedrês mostra inquestionável simpatia pela figura do Major, o que não é suficiente para concluir que no conto se faça a apologia da figura do desbravador ou do coronel; de fato, as demais personagens de Sagarana que detêm o poder apresentam enorme variedade de características pessoais, e o caso do Major Saulo é, na verdade, particular e isolado: o Major Anacleto e seu irmão, Tio Laudônio, de A volta do marido 
pródigo, tio Emílio, de Minha gente, Coronel Melguério, de Corpo fechado, Nhô Augusto e Major Consilva, de A hora e vez de Augusto Matraga.

O que esses homens têm em comum é o comando, mas com características diversificadas: alguns são bons comandantes, outros não. Os homens e as mulheres que dependem do poder arbitrário desses homens podem ser mais ou menos felizes, dependendo de quem os governe, e seu destino é marcado pela casualidade mais do que pela previsibilidade. Se, como afirma Freud em O mal-estar da civilização, “A ordem é uma espécie de compulsão a ser repetida, compulsão que, ao se estabelecer um regulamento de uma vez por todas, decide quando, onde e como uma coisa será efetuada, e isso de tal maneira que, em todas as circunstâncias semelhantes, a hesitação e a indecisão nos são poupadas.” (FREUD, 1974, vol. 21, p. 113), concluímos que a situação casuística provocada pelo exercício do poder privado arbitrário é incompatível com o estabelecimento da ordem em um meio social. Portanto, em Sagarana não é na ordem coronelística em si que se origina a desordem e seu corolário, a violência, porque um bom governante como o Major Saulo pode ser um mantenedor da ordem e do progresso econômico, e um pusilânime como Melguério não consegue se livrar de um valentão ameaçador descarado de uma comunidade que, no final das contas, se mostra frágil. A fonte da desordem está na atitude casuística de um poder privado arbitrário e desmedido. O Major Saulo - poderoso representante da família patriarcal brasileira no sentido amplo do termo, que abrange não só o círculo familiar, mas também dependentes econômicos e de compadrio - instaura a ordem, localizando-a no meio da desordem brasileira; mas essa ordem é precária e efêmera, porque personalizada em um homem, e não emanada de um Estado organizado com poder para conter a violência. E, quando ele se afasta, instaura-se a desordem e ocorre a tragédia.

Pode - se afirmar que em Sagarana há a consistente escolha de um momento histórico, o da República Velha, cujo ambiente social se consubstanciava na predominância de um exorbitante poder privado nas relações sociais. Graças a isso, as diversas tramas são capazes de mostrar as conseqüências sociais da fragilidade das instituições oficiais e do poder do Estado. A obra não faz a apologia do estado totalitário, apologia que levaria embutida a legitimação da ditadura getulista - embora Rosa parecesse nutrir simpatia por Getúlio, como mostra seu discurso de posse na ABL -, pois não existem elementos textuais que comprovem essa tese. As noções presentes em Sagarana são mais amplas e teóricas, são de caráter conceitual mais do que histórico, possivelmente relacionadas com questões ligadas ao transplante, para o Brasil, 
da descentralização do poder, como efetivado por Rui Barbosa no projeto na primeira Constituição republicana de 1891, inspirada no modelo norte-americano: “Tínhamos então os olhos fitos nos Estados Unidos”, diria Rui (BARBOSA, 1972, p. 482). ${ }^{13}$ Sobre esse aspecto, o livro parece endossar as idéias ligadas à cordialidade brasileira sobre democracia expressas no capítulo O homem cordial de Raízes do Brasil:

Na verdade, a ideologia impessoal do liberalismo democrático jamais se naturalizou entre nós. Só assimilamos efetivamente esses princípios até onde coincidiram com a negação pura e simples de uma autoridade incômoda, confirmando nosso instintivo horror às hierarquias e permitindo tratar com familiaridade os governantes. A democracia no Brasil foi sempre um lamentável mal-entendido. Uma aristocracia rural e semifeudal importou-a e tratou de acomodá-la, onde fosse possível, aos seus direitos ou privilégios, os mesmos privilégios que tinham sido, no Velho Mundo, o alvo da luta da burguesia contra os aristocratas. E assim puderam incorporar à situação tradicional, ao menos como fachada ou decoração externa, alguns lemas que pareciam os mais acertados para a época e eram exaltados nos livros e discursos. (HOLANDA, 1999, p. 160)

Roncari demonstrou que, em alguns temas, as idéias de Guimarães Rosa alinham-se às de Oliveira Vianna e isso parece ocorrer no caso do debate entre centralização e descentralização do poder. A crítica de Oliveira Vianna à Constituição de 1891 é incisiva e clara; ele distingue a descentralização política da descentralização administrativa e mostra-se contrário à primeira e partidário da segunda, porque "No Brasil, o inimigo das liberdades sempre foi o poder local.” (VIANNA, 1987a, vol. 2, p. 42) e “a descentralização política terá que resultar, fatalmente, em mandonismo, em coronelismo, em regulismo, em satrapismo, em dissociacionismo, em separatismo” (VIANNA, 1987a, vol. 2, p. 135). Estas considerações de Oliveira Vianna e de Holanda aplicam-se com propriedade em quase todas as relações sociais presentes em Sagarana, e, como veremos, com ênfase maior, nos dois contos que tratam especificamente do jogo político,

O levantamento das características dos detentores do poder, como acima descritas, tem alguns desdobramentos de interesse para este nosso trabalho: em primeiro lugar, o fato de homens de condição social análoga apresentarem características de comando essencialmente diversas; em segundo lugar, as personagens de Sagarana, no

\footnotetext{
${ }^{13}$ Guimarães Rosa não tinha Rui Barbosa em grande apreço. Em carta à esposa de 7 de julho de 1934, ele fala que no concurso do Itamarati teve que escrever sobre "Ruy Barbosa: sua influencia nas lettras, na politica nacional, e na Conferencia de Haya". "Foi minha peor nota, (...) "porque fallei algumas verdades contra Ruy Barbosa” e o examinador era ruysta enthusiastico.” (ROSA, V. G., 1999, p. 322-33). Em Sezão, como veremos, Rei-Barbosa e é nome do "novo Imperador", dado pelo cego conduzido pelo bode que Matraga encontra em sua viagem de Tombador para Rala-Coco.
} 
conjunto da obra, nada têm de esquemáticas, como às vezes pode parecer quando analisamos um conto sem a visão de conjunto do livro. O exemplo dos homens do poder que demos aqui não é único, pois outras categorias sociais de homens e mulheres mostram o mesmo comportamento diversificado. A aparente esquematização de algumas personagens de Sagarana, tomada isoladamente, parece ter a utilidade didática de mostrar ao leitor, por intermédio de uma perfeita caracterização, o quanto elas, tomadas em conjunto, podem ser diversas umas das outras. Como dissemos, a análise isolada de $O$ burrinho pedrês leva-nos a concluir que em Sagarana é sustentada a tese conservadora de que o coronelismo foi elemento gerador de progresso e de ordem, tese que é contrariada em outros contos do livro. Por outro lado, teríamos personagens estereotipadas se todos os mandões do livro tivessem características parecidas, tal como, a propósito, ocorre em várias obras da época de Guimarães Rosa, nas quais o coronel é pintado como um bruto retrógrado.

Encerraremos esta nossa análise mencionando três vertentes em que estão divididas as forças que se opõem ao progresso em $O$ burrinho pedrês: uma, a ausência de espírito empreendedor, representada principalmente por Francolim e Manico; outra, a inanição, o saudosismo, a tendência ao retrocesso, ou, resumindo, "espírito do Calundú”, cujo modelo é o negrinho; e outra ainda, e mais importante, a tendência natural dos seres à violência e à desordem, tendo em Silvino seu melhor representante, porém presente em menor ou maior grau em outras personagens do conto. Como intermediário entre esses extremos de tendências ao progresso e ao retrocesso, está o burrinho: um sábio ausente dos problemas alheios, cujo conhecimento não se volta para o bem comum, mas que pode ser utilíssimo se aproveitado com cautela e sabedoria.

A propósito deste, uma questão intriga: que lugar ocuparia a figura de um sábio estóico, Sete-de-Ouros, ou que papel desempenharia o estoicismo num conto que, como o O burrinho pedrês, aborda de forma tão pujante um assunto como a violência e elementos correlatos (contrato social e civilização), ou essencialmente brasileiros (como a figura do desbravador, a melancolia, o arbítrio do poder) etc? Não temos elementos para responder satisfatoriamente a essa pergunta. No entanto em se falando de ordem e de progresso e do positivismo que os conceitos encerram, ocorre-nos a hipótese de que sua figura contenha uma crítica ao pensamento racionalista - criticado nos outros contos de Sagarana, em especial em São Marcos e A volta do marido pródigo - herdado do Iluminismo, que buca a subjugação da natureza - como empreendida pelos homens que 
se afogaram -, ao contrário do burrinho, que se entregou a ela e não tentou subjugá - la. Seria ele um bem-aventurado pobre de espírito? Ou seria também o indivíduo que exemplifica a tese postulada por Sérgio Buarque de Holanda sobre a auto-suficiência dos portugueses e espanhóis, responsável pela falta de coesão social no Brasil: "Sua manifestação mais completa já tinha sido expressa no estoicismo que, com pouca corrupção, tem sido a filosofia nacional dos espanhóis desde o tempo de Sêneca.” (HOLANDA, 1999, p. 32).

Sagarana passou a trazer ilustrações a partir da $5^{\text {a. }}$ edição e, segundo Poty, foram supervisionadas pelo próprio autor: "Ele exigia, por exemplo, que a imagem de um sapo fosse colocada dentro de um círculo, em cima de um poste de telégrafo. Eu nunca entendi isso, mas fiz." ${ }^{14}$ As ilustrações foram mudadas na $12^{\text {a }}$ edição, de 1970 , portanto três anos após o falecimento de Rosa (não conseguimos levantar informações que confirmassem que Poty tenha feito as ilustrações da $12^{\text {a }}$ até a $23^{\text {a }}$ edições antes de 1967 , com Rosa ainda vivo para supervisioná-lãs). As edições posteriores, até a $23^{a}$, conservaram as ilustrações da $12^{\mathrm{a}}$ e, na $24^{\mathrm{a}}$, comemorativa dos 35 anos de Sagarana, foram repetidas as das primeiras edições, com várias exclusões e algumas alterações de posição em relação ao texto. As edições seguintes repetiram as ilustrações da $24^{\text {a }}$ até que, na $28^{\mathrm{a}}$, elas lamentavelmente foram eliminadas quando a Nova Fronteira passou a editar Sagarana.

A dificuldade de compreensão do papel do burrinho no conto talvez seja a razão pela qual a ilustração da página $27 \mathrm{da}$ $5^{a}$. edição transforma o burrinho em três cavalos de jogo de xadrez, colocados em enigmáticas posições.

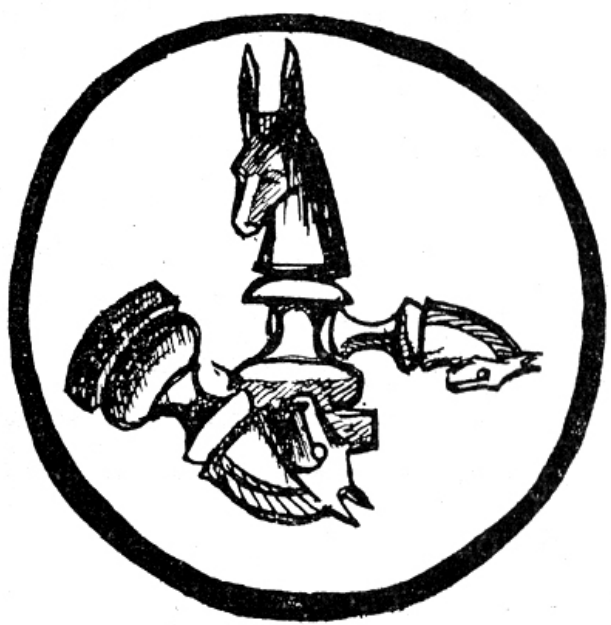

\footnotetext{
${ }^{14}$ Entrevista de Poty à revista Veja de 28/1/98
} 


\section{A VOLTA DO MARIDO PRÓDIGO}

Os contos A Volta do marido pródigo e São Marcos foram meticulosamente analisados por Luiz Roncari em seu O Brasil de Rosa (RONCARI, 2004) ${ }^{15}$ e, portanto, a nossa análise daquelas duas obras, seria, a rigor, dispensável, bastando que nos ocupássemos aqui de levantar, à luz do texto de Roncari, em quais aspectos os dois contos guardam alguma relação com os demais de Sagarana. No entanto, acreditamos que seja de interesse elaborarmos uma síntese daquelas interpretações e adicionarmos as observações pessoais que se mostrarem apropriadas, por algumas razões: a primeira, é que um trabalho que trata, primordialmente, de demonstrar a unidade de um livro, ficaria incompleto se dois de seus contos não tivessem nela um lugar reservado; a segunda, é que uma síntese sempre envolve escolhas e, ao sintetizarmos aquelas leituras, estaremos por critério próprio optando por aquilo que consideramos realmente essencial para demonstrar nossas idéias no texto de partida; e, terceiro, por sua própria abertura e complexidade, sempre serão possíveis leituras consistentes do texto, ainda que não totalmente concordantes, ou mesmo conflitantes em certos aspectos.

Em $A$ volta do marido pródigo são mostradas principalmente quatro noções que entendemos estar relacionadas com a representação do Brasil: a forma do exercício da política partidária na República Velha, as relações familiares, a prática da cordialidade brasileira e a questão racial.

A cordialidade é a noção central do conto e emerge da composição das atividades do protagonista nas esferas privada, concentrada na sua vida familiar e que justifica o título do conto, e na pública, que relata suas atividades na política partidária e no trabalho. A relação entre a atividade política e a vida familiar é tão estreita na obra, que as ações do protagonista, assim como de outras personagens, são conduzidas simultânea e indistintamente nas duas esferas.

A volta do marido pródigo não finaliza a discussão em torno desses tópicos. Eles serão tratados em outros contos do livro, para completar um quadro geral do exercício da prática da política, da família patriarcal, de aspectos raciais, da cordialidade. Mas, nenhum outro conto explora este último aspecto tão agudamente.

\footnotetext{
${ }^{15}$ Em O cão do sertão Roncari apresentou aspectos importantes de outros contos de Sagarana, como Sarapalha, Minha gente e outros. (RONCARI, 2007)
} 
O conto possui duas epígrafes:

“Negra danada, siô, é Maria:

ela dá no coice, ela dá na guia,

lavando roupa na ventania.

Negro danado, siô, é Heitô:

de calça branca, de paletó,

foi no inferno, mas não entrou!”

(CANTIGA DE BATUQUE, A GRANDE VELOCIDADE.) (p. 69)

“- Ó seu Bicho-Cabaça!? 'Viu

uma velhinha passar por aí?...

- Não vi velha, nem velhinha,

corre, corre, cabacinha...

Não vi velha nem velhinha!

Corre! corre! cabacinha...”

(DE UMA ESTÓRIA.)... (p. 69)

As duas epígrafes estão intimamente relacionadas à figura do protagonista. $\mathrm{Na}$ primeira, Maria consegue lavar roupa na ventania ao mesmo tempo em que bate na dupla de guia - a que vai à frente de um carro de bois de quatro duplas - e na de coice, a quarta dupla; Heitô, por seu turno, vai ao inferno, mas não entra - tarefa que faz lembrar a história do sapo que engana São Pedro, narrada no capítulo do V conto (p. 92-3). A cantiga de batuque fala, portanto da competência de alguém de enfrentar situações ou realizar tarefas de grande dificuldade. Por outro lado, o trecho da história da segunda epígrafe refere-se a uma habilidade que complementa a da primeira, a de realizar as tarefas com presteza. Lalino mostra-se hábil das duas formas, porque atua bem e rápido, quer como cabo eleitoral do Major Anacleto, quer na reconquista de sua mulher.

O capítulo I do conto tem lugar em uma obra de construção da estrada de rodagem que liga Belo Horizonte a São Paulo, substituta dos velhos ramais ferroviários de bitolas variadas. Ela representa, portanto, a via de chegada da modernização ao interior. A atividade é intensa e, para maior incentivo da força de trabalho, o pagamento se faz por meio de medição do material removido; uma equipe de operários, comandada por "seu Marra bate rijo de picareta, atacando no paredão pedrento a brutalidade cinzenta do gneiss" (p. 70), enquanto que a dos "espanhóis cavouca terra mole, xisto talcoso e micaxisto” (p. 70). Serviços particulares também estão em andamento: os homens de seu Remígio, dono de terras, lavram uma jazida de amianto, introduzindo uma atividade mineira no local de atividade agrícola, e os de Ludugéro fazem uma 
ponte. Mas, são os burros de carga, com suas naturezas dóceis, os que melhor simbolizam a moderna técnica do trabalho em série, monótono, metódico e rigorosamente cronometrado, executável sem qualquer necessidade ou possibilidade de emprego de criatividade; a ordenação do movimento dos animais é sinalizada pelas quatro frases rimadas duas a duas que iniciam a passagem:

NOVE horas e trinta. Um cincerro tilinta. É um burrinho, que vem sozinho, puxando o carroção. Patas em marcha matemática, andar consciencioso e macio, ele chega, de sobre-mão. Pára, no lugar justo onde tem de parar, e fecha imediatamente os olhos. Só depois é que o menino, que estava esperando, de cócoras, grita: - "Isia!...” - e pega-lhe na rédea e o faz volver esquerda, e recuar cinco passadas. Pronto. O preto desaferrolha o taipal da traseira, e a terra vai caindo para o barranco. Os outros ajudam, com as pás. Seis minutos: o burrinho abre os olhos. O preto torna a aprumar o tabuleiro no eixo, e ergue o tampo de trás. O menino torna a pegar na rédea: direita, volver! Agora nem é preciso comandar: - "Vamos !”... - porque o burrico já saiu no mesmo passo, em rumo reto; e as rodas cobrem sempre os mesmos sulcos no chão.

No meio do caminho, cruza-se com o burro pêlo-de-rato, que vem com o outro carroção. É o décimo terceiro encontro, hoje, e como ainda irão passar um pelo outro, sem falta, umas três vezes esse tanto - do aterro ao corte, do corte ao aterro - não se cumprimentam. (p. 69-70)

Ao entrar em cena, Lalino introduz uma ruptura no clima de trabalho; chega atrasado, tenta driblar as regras a que os demais trabalhadores se submetem, vem trajado de modo inadequado ao exercício de atividades braçais, finge não ouvir ou entender o sarcasmo dos colegas: “Os colegas põem muito escárnio nos sorrisos, mas Lalino dá o aspecto de quem estivesse recebendo uma ovação” (p. 71). Não tem escrúpulos em tapear o chefe e prejudicar os companheiros, mente de modo descarado. É descrito, física e moralmente, como um mulato preguiçoso, astuto, sem caráter e imaginativo. Conversa muito e faz pouco ou nada, quando não leva os outros a trabalhar por ele. Mas consegue que seu Marra lhe abone as horas de atraso, tirando vantagem da característica do chefe de fazer que seu gosto por teatro, um interesse particular e restrito à sua esfera privada, interfira no seu cargo de comando, função relativa à esfera pública. Na verdade, ele é um mestre em tirar proveito das situações e das forças e fraquezas alheias, dentre as quais estão a vulnerabilidade à lisonja e a cordialidade; mesmo a forma de Lalino dirigir-se ao chefe, "seu Marrinha”, empregando o diminutivo no tratamento pessoal, é um sintoma de cordialidade, como se lê em Raízes do Brasil (HOLANDA, 1999, p. 148); ao explorar os pontos fracos dos que com ele se relacionam, Lalino se torna simpático aos olhos de seus superiores, como pode ser 
observado no diálogo entre seu Marra e seu Waldemar, para cuja esposa o protagonista espertamente dá aulas de violão a domicílio:

- Mulatinho levado! Entendo um assim, por ser divertido. E não é de adulador, mais sei que não é covarde. Agrada a gente, porque é alegre e quer ver todo-o-mundo alegre, perto de si. Isso, que remoça. Isso é reger o viver.

- É o que eu acho... Só o que tem, que, às vezes, os outros podem aprovar mal o exemplo...

- Concordo. Já pensei, também...Vou arranjar para ele um serviço à parte, no armazém ou no escritório...E é o que convém, logo: veja só...(p. 80).

Ao mesmo tempo em que pratica a cordialidade, Lalino sabe manter os outros distantes de sua vida privada; observe-se, por exemplo, na passagem abaixo, a maneira hábil pela qual se livra de Generoso, que lhe traz a informação - já conhecida dele, como saberemos no desenrolar da história - sobre o assédio do espanhol Ramiro a sua mulher. Na verdade, além da preservação de sua privacidade, a atitude de Lalino tem o objetivo de esconder do público o fato de ele ter ciência das investidas do espanhol sobre Maria Rita; se demonstrasse o conhecimento do assédio, teria de explicar por que ainda não tivera nenhuma reação violenta, exigida pelo código do meio social, coisa que não está em seus planos de vida:

- Então, seu Laio, esse negócio mesmo do espanhol...

- Ara, Generoso! Vem você com espanhol, espanhol.. Eu já estou farto dessa espanholaria toda... Inda se fosse alguma espanhola, isto sim!

- Mas, escuta aqui, seu Laio: o que eu estou falando é outra coisa...

- É nada. Mas, as espanholas!...Aposto que vocês nunca viram uma espanhola... Já?... Também, - Lalino ri com caretas - também aqui ninguém não conhece o Rio de Janeiro, conhece?... Pois, se algum morrer sem conhecer, vê é o inferno!

O capítulo II narra a relação, revestida de forte carga de sensualidade, de Lalino com Maria Rita, os preparativos da partida e a viagem do protagonista ao Rio de Janeiro. Já em vias de se evadir, ele entabula com seu Miranda um diálogo que mostra uma outra faceta de seu caráter, a de homem normalmente pacato, mas pronto para utilizar a violência quando julgar necessário: “- Olha, seu Miranda: eu, com o senhor, de qualquer jeito: à mão, a tiro, ou a pau, o senhor não pode comigo - isto é - não é?...” (p. 86).

Como já sucedera no capítulo anterior, Lalino deixa-se levar pela imaginação e por isso prefere as imagens da revista de mulheres da capital à realidade da apaixonada mulher que se enfeita para agradá-lo (p. 82). O capítulo se encerra com o protagonista 
imaginando e saboreando de antemão as farras e orgias que o esperam no Rio de Janeiro, “onde odaliscas veteranas apregoavam aos transeuntes, com frinéica desenvoltura, o amor: bom, barato e bonito, como o queriam os deuses.” (p. 86). Esta passagem faz uma referência à luxúria que cerca a relação do protagonista com a mulher e que o move para a grande cidade, porque em Frinéia, intérprete e sacerdotisa de Afrodite, o sapo simboliza a luxúria e Lalino é diretamente associado aos sapos pelo narrador: "Lalino Salãthiel nem mesmo sabia que era da grei dos sapos” (p. 93).

O breve capítulo III narra a ligação de Maria Rita com o espanhol Ramiro. Os comentários do povo são claramente desfavoráveis a Lalino, como na passagem na qual, mais uma vez, sua condição racial é lembrada: “- Mulatinho indecente! Cachorro lambeu a vergonha da cara dele! Sujeito ordinário... Eu em algum dia me encontrar com ele, vou cuspindo na fuça!” (p. 87).

No Capítulo IV, são narradas a vida devassa do protagonista no Rio de Janeiro, a decepção com as mulheres de bordel, a saudade de casa, a decisão de retornar ao lar, as farras derradeiras de despedida da grande cidade e o retorno, triste. Este capítulo aproxima o conto à parábola do filho pródigo narrada no Evangelho de São Lucas, 15, 11-32. O arrependimento e o retorno de Lalino têm duas origens: a escassez de dinheiro e a decepção com a falsidade das profissionais do amor, lindas e sedutoras, que haviam sido a razão do seu abandono do lar. Aquelas que o levaram a sonhar com um falso paraíso terrestre são equiparadas no texto às huris, beldades celestes que hão de ser esposas dos fiéis muçulmanos. Desolado, ele lamenta a perda do amor sincero de Maria Rita:

As aventuras de Lalino Salãthiel na capital do país foram bonitas, mas só podem ser pensadas e não contadas, porque no meio houve demasia de imoralidade. Todavia, convenientemente expurgadas, talvez mais tarde apareçam, juntamente com a estória daquela rã catacega, que, trepando na laje e vendo o areal rebrilhante à soalheira, gritou “Eh, aguão!...”- e pulou com gosto, e, queimando as patinhas, deu outro pulo depressa para trás. Portanto: não, não fartava. As huris eram interesseiras, diversas em tudo, indiferentes, apressadas, um desastre; não prezavam discursos, não queriam saber de românticas histórias. A vida... Na Ritinha, nem não devia de pensar. Mas, aquelas mulheres, de gozo e bordel, as bonitas, as lindas, mesmo, mas que navegavam em desafino com a gente, assim em apartado, no real. Ah, era um outro sistema.

Aquilo cansava, os ares. Havia mal o sossego, demais. Ah, ali não valia a pena. (p. 87-8) 
A viagem de retorno descreve a mudança que vai se operando na personagem, que começa com sua entrada no trem - "Quando entrou no carro, aconteceu que ele teve vontade de procurar um canto discreto, para chorar.” (p. 88) - e termina quando desperta no dia seguinte "pomposamente, terrivelmente feliz.” (p.89). Os sentimentos de Lalino nesta viagem de volta estão em franca contraposição às ilusões que alimentava na viagem de ida. O amor verdadeiro de Maria Rita fora vendido como mercadoria e substituído pelo amor comprável e simulado de lindas mulheres; mas a experiência vivida traz a consciência da dimensão do bem perdido e leva o protagonista a empenhar-se com afinco para recuperá-lo. Talvez no tema da distinção do amor verdadeiro e do amor ilusório ou entre amor e luxúria esteja uma moral da parábola do marido pródigo, narrada nas aventuras de Lalino Salãthiel na Cidade Maravilhosa. Essa moral sobre o amor, embora seja interessante, não é suficientemente ampla para justificar o papel central que a política representa no conto.

Os atributos pessoais de Lalino, dos quais tão bem se aproveitava e aproveitará no sertão, tornam-se inoperantes na grande cidade e, por isso, ele tem dificuldade de conseguir trabalho - “O dinheiro se fora. Rareavam os biscates. Veio uma espécie de princípio de tristeza. E ele ficou entibiado e pegou a saudadear.” (p. 88). Em seu retorno ao lar, ele poderá novamente utilizar-se daqueles valiosos atributos para se projetar na política como excelente cabo eleitoral e, em troca por seus serviços, reaver a mulher. Lalino é, portanto, um vencedor em sua terra, mas é um perdedor na capital, onde os hábitos, os costumes, os valores e o progresso lhe são estanhos. É claro que o local onde vive está em processo de receber o progresso por meio da estrada de rodagem em construção, mas ele não se adapta ao trabalho disciplinado exigido a homens e burrinhos no exercício das tarefas. Somente em sua terra e em seu estado de atraso é que ele apropriadamente desempenha seu papel. Se, como dissemos, o aspecto político é significativo no conto, é razoável relacionar o fracasso de Lalino na capital do país com os outros aspectos políticos que detectamos na obra. Podemos então afirmar que a personagem é talhada para a política local, mas inadequada à política praticada na capital. Mas, durante a Primeira República a maior parte do eleitorado era constituída por trabalhadores rurais que obedeciam à orientação dos fazendeiros, os quais, por sua vez, seguiam os líderes políticos municipais. Como o poder municipal se fortalecia por meio da criação de compromissos de sustentação política com os governos estaduais, a atuação eficaz de Lalino ocorre justamente na base eleitoral do sistema político, e neste o protagonista se move com estupenda desenvoltura; por essa razão, sua atuação local 
poderá levá-lo a se projetar na esfera estadual em função da simpatia que inspira no Secretário do Interior. O caminho inverso não seria possível porque, para adquirir projeção política na capital, ele não possui o cacife inicial necessário - e aí se incluem apadrinhamento, compadrismo, nepotismo e toda sorte de conchavos - porque, como diz o narrador, "a política é ar fácil de se respirar - mas para os de casa, que os de fora nele abafam, e desistem.” (p. 108).

O capítulo V começa com Lalino inventando formas espirituosas para enfrentar as caçoadas e as interpelações dos habitantes locais em sua caminhada para a casa do espanhol Ramiro. Após o encontro com o amante de Maria Rita, elabora um projeto para resgatá-la e ao mesmo tempo alcançar, como importante subproduto, projeção social na comunidade. Seu patrimônio de partida é negativo: a mulher não o quer, e ele é rejeitado pelo seu grupo social.

A narrativa desse capítulo cobre uma série de eventos breves e descritivos do caráter do protagonista - que adicionam novos dados aos já fornecidos nos capítulos anteriores - e das técnicas que ele irá empregar para realizar seu plano. Sem um tostão no bolso, blefa com o espanhol, ao mostrar disposição de devolver o dinheiro que este lhe emprestara: “O dinheiro estava aqui na algibeira, mas, já que está tudo quites, acabou-se. Não sou homem soberbo!...” (p.103). Nesse mesmo diálogo com o espanhol, ele mostra sua disposição de aplicar a força, se necessário, como já fizera com seu Miranda "Espera, o senhor está tratando bem da Ritinha? Ahn, não é por nada não. Mas, se eu souber que ela está sendo judiada!...” (p. 90). A mesma disposição de emprego da violência pode ser observada na passagem em que Lalino diz ao espanhol que quer conversar com a esposa: "Lalino batera a mão no cinturão, na coronha do revólver, como por algum mal, e estava com os olhos nos do outro, fincados.” (p. 90). Um de seus atributos é a paciência, que lhe será utilíssima nos dois campos em que atuará, no afetivo e no político, pois, lenta e objetivamente, colocará em prática uma estratégia que o levará ao êxito: “Eu quisesse, à força, hoje mesmo a Ritinha vinha comigo... E se... Ah, mas tem os outros espanhóis, também... Diabo! É, então vamos ver como é que a abóbora alastra.... e deixa o tiziu mudar as penas, p’ra depois cantar...” (p. 91). Lalino sabe empreender a retirada estratégica quando prevê que as coisas podem ir mal, mas ainda assim, aproveita a oportunidade de ludibriar o rival: “- Qual, resolvi... Bobagem. Quero ver mais a minha mulher também não... O que eu preciso é do meu violão... Está aí, hem?” (p. 90). Quando está sendo verbalmente atacado ou em vias de sê-lo, sabe 
contra-atacar e reverter uma situação de inferioridade; por exemplo, ataca o Jijo antes de ser ofendido por ele (p. 91). Por meio da história do cágado e do sapo, na qual este engana até mesmo São Pedro (p. 92-3), o narrador fala-nos da astúcia da personagem; o sapo, como vimos, é a representação de Lalino. Como podemos observar, seu caráter está em perfeita sintonia com a prática da política brasileira, e todos os acontecimentos narrados que lhe dizem respeito estão centralizados nessa idéia.

Nesse mesmo capítulo é introduzida a personagem Oscar. Quando Lalino pensa em ir ao encontro de seu Marrinha, certamente para engabelá-lo com sedutoras propostas teatrais a fim de obter emprego, casualmente vem a seu encontro o filho do chefe político do distrito, Major Anacleto. No diálogo entre os dois homens, Lalino, como pessoa dotada de tino para a política, mantém o respeito devido a um filho de major, mas isto não o impede de mentir, se mentir for o que mais lhe convier no momento. Oscar, por seu turno, procura colocar Lalino em débito com a moralidade, para então prometer auxiliá-lo a se emendar. Mas, seu auxílio é uma forma astuta de comprometer o outro, pois o que Oscar realmente pretende é utilizar Lalino na batalha política que se desenrola no local e para a qual este parece talhado: “- Eu acho de encomenda, p’ra um como você, tomar uma empreitada com essa política, que está brava...” (p. 95)

Ainda nesse diálogo, Lalino dá outra mostra de sua imaginação ao idealizar um mundo hipotético, onde todos os desejos são alcançados sem nenhum esforço de trabalho físico ou mental:

Este mundo é que está mesmo tão errado, que nem paga a pena a gente querer concertar... Agora, fosse eu tivesse feito o mundo, por um exemplo, seu Oscar, ah! isso é que havia de ser rente!...Magina só: eu agora estava com vontade de cigarrar... Sem aluir daqui, sem nem abrir os olhos direito, eu esticava o braço, acendia o meu cigarrinho lá no sol... e depois ainda virava o sol de trás p'ra diante, p'ra fazer de-noite e a gente poder dormir... Só assim é que valia a pena... (p. 94-5).

Duas personagens mais são introduzidas no capítulo VI: o Major Anacleto, e seu irmão, Tio Laudônio. O narrador descreve-lhes o caráter com apuro, ao mesmo tempo em que adiciona informações sobre o caráter de Oscar.

Das quatro personagens principais do conto - Lalino, Oscar, Laudônio e Anacleto -, o Major, justamente aquele que ostenta o poder, é, de longe, o menos astuto e inteligente e, por esse motivo, facilmente manipulado, quando não tapeado pelos outros três. Por causa de sua estupidez, agregada ao seu temperamento estabanado, 
emite juízos sem melhor análise, autoritários, apressados e intempestivos, sob forte carga emocional - e, por isso mesmo, geralmente errados -, que devem freqüentemente ser reconsiderados. Indeciso e inseguro, teme tomar decisões. Por isso, suas atitudes ficarão, a partir de sua entrada em cena até o final do conto, em permanente vai-e-vem, como, por exemplo, no caso em que Oscar pede o engajamento de Lalino na campanha política, narrado neste capítulo:

- Não me fale mais nisso, seu Oscar. Definitivamente! Aquilo é um grandissíssimo cachorro, desbriado, sem moral, e sem temor de Deus... Vendeu a família, o desgraçado! Não quero saber de bisca dessa marca. E, depois, esses espanhóis são gente boa, já me compraram o carro grande, os bezerros... Não quero saber de embondo! (...)

Mas, aí, Tio Laudônio - sensato e careca, e irmão do Major - viu que era a hora de emitir o seu palpite, quase sempre o derradeiro. (p. 97)

- Bem, bem, já que todos estão pedindo, que seja.! Mandem recado p’ra ele vir amanhã. Mas é por conta de vocês...(p. 98)

Tio Laudônio é a voz sensata que vem da experiência de vida. É um mestre na arte de persuasão e, por essa razão, tem enorme ascendência sobre o indeciso Anacleto. É uma espécie de sábio rural, indolente e boa-vida, o melhor estrategista e o mais inteligente e arguto do trio familiar. Roncari mostra que o nome da personagem, Laudônio, é uma evolução do "laus/laudare” latino, com sentido de “louvor”, “glória”, “exaltação”, ao "laus” germânico, “piolho”, um hospedeiro que depende do sangue de outro para a sobrevivência; ressalta que Laudônio possui dotes naturais que foram cultivados, de um lado, por sua formação intelectual no seminário - onde tomou contato com a vida espiritual - e, de outro, pela boêmia, que lhe ensinou o lado mundano da vida. "Devoto por hábito e casto por preguiça, vive enfurnado, na beira do rio, pescando e jogando marimbo, quando encontra parceiros.” (p. 97). Roncari identifica-o com o intelectual da Primeira República (RONCARI, 2004, p. 48). Seus princípios religiosos não são suficientemente robustos para impedirem-no de sugerir ao irmão o aproveitamento maquiavélico de um inescrupuloso transgressor dos mandamentos, como Lalino. Vê, neste último, dotes inatos extraordinários, entre os quais sua condição de mulato:

- Um mulato desses pode valer ouros... A gente esquenta a cabeça dele, depois solta em cima dos tais, e sopra... Não sei se é de Deus mesmo, mas uns assim têm qualquer um apadrinhamento... É uma raça de criaturas diferentes, que os outros não podem entender... Gente que pendura o chapéu em asa de corvo e guarda dinheiro em boca de jia... Ajusta o mulatinho, mano Cleto, que esse-um é o Saci (p. 98). 
Oprimido por um pai arbitrário e autoritário, que nele vê apenas um rapazola incompetente, Oscar é forçado a agir com cautela e empregar artimanhas e ardis para conseguir desempenhar algum papel, ainda que discretíssimo, na campanha política na qual o pai está empenhado. Sua capacidade de decisão dentro do grupo familiar é quase nula e nos dois capítulos seguintes ele acompanhará fisicamente o pai em suas andanças para caçar votos, mas o narrador não lhe dará voz. Como resultado do permanente jogo de simulações que desenvolve na dominadora presença paterna, as várias facetas de seu caráter só vão sendo mostradas à medida que o conto se desenrola.

Os capítulos VII e VIII são destinados à descrição dos sujos jogos políticos, nos quais brilha o protagonista em seu trabalho de cabo eleitoral do Major.

Boa parte do capítulo VII é tomada pelo relato meticuloso, por Lalino, dos passos tomados e das intrigas urdidas por Benigno, rival político do Major, para atrair os eleitores deste último. Em pouco tempo Lalino consegue levantar e interpretar as táticas de guerra do inimigo político do Major, coisa que nem Oscar, por incompetência, nem Laudônio, por preguiça, nem o Major, por estupidez, haviam conseguido. Paralelamente, tendo sempre em mente o propósito de recuperar a mulher e adquirir prestígio social com o cargo de cabo eleitoral do Major, pede a este a proteção de "Estêvam - o Estêvão -, um dos mais respeitáveis capangas do Major Anacleto, sujeito tão compenetrado dos seus encargos, que jamais ria.” (p. 100). "E assim o povo do arraial ficou sabendo que ele era o cabo eleitoral de seu Major Anacleto, e que tinha de receber respeito.” (p. 101).

Uma passagem curiosa deste capítulo mostra a insegurança do Major em tomar decisões:

Está aí, seu Major. Por deus-do-céu, como isto tudo que eu lhe contei é a verdade! ...

- Espera, espera aí, seu Eulálio... Espere ordens!

E o Major, estarrecido com as novidades, e furioso, chamou Tio Laudônio ao quarto-da-sala, para uma conferência. Durou o prazo de se capar um gato. Quando voltaram, o Major ainda rosnava:

- E o Antenor! E o Martinho Boca-Mole!... E eu sem saber de coisa nenhuma!

- Não é nada, mano, isto é o começo da graça... Dá dinheiro ao mulatinho, que a corda nele eu dou... Cem mil-réis é muito, cinqüenta é o que chega, p’ra principiar...(p. 100). 
No capítulo VIII, Lalino empreende ações estratégicas com base no levantamento da situação narrado no capítulo anterior. Essas ações correm paralelamente nos dois campos de interesse do protagonista, o familiar e o político.

Sugerido pelo relato de Lalino do capítulo VII, o major visita o vigário e promete-lhe o cargo de inspetor escolar, mas fica sabendo que seu astuto cabo eleitoral já antes ali estivera, enganando jeitosamente o pároco para atingir seu duplo objetivo:

- Sabe, Major? Quem esteve aqui ontem foi esse rapaz que agora está trabalhando para o senhor. Também se confessou e comungou, e ainda trocou duas velas para o altar de Nossa Senhora da GIória... E rezou um terço inteiro, ajoelhado aos pés da Santa. O caso dele, com a mulher mais o espanhol, é muito atrapalhado, e por ora não se pode fazer coisa alguma... Mas, havendo um jeito...Como bom católico, o senhor não ignora: a gente não deve poupar esforços visando à reconciliação de esposos. Aliás, só lhe falo nisso porque é do meu dever. O moço não me pediu nada, e isso prova que ele tem delicadeza de sentimentos. Depois, assim com tanta devoção à Virgem Puríssima, ninguém pode ser pessoa de todo má...(p. 101-2)

Como sugere seu nome, o protagonista é um ladino, e isto é mostrado no episódio acima: quando fez o relato das andanças de Benigno ao Major, já estivera com o vigário; por isso, estimulou Anacleto a visitar o pároco, para ouvir deste o pedido de reatamento com Maria Rita e constatar pessoalmente o excelente trabalho que havia realizado junto ao religioso. Além disso, ao ocultar o episódio, mostrou ao Major ser um homem modesto, capaz de realizar atos tão estupendos, que a simples conversão de um pároco à sua causa política não merecia sequer ser mencionada.

O protagonista relata então todas as manobras que executou para ir convertendo em aliados os opositores do Major. Por meio de complicada argumentação, conseguiu dar bom termo a uma disputa entre Antenor e Martinho, lançando mão de leis, mentiras e ameaças que assustaram os dois contendores, falando da intervenção do governo para solucionar a pendência: "Falei que agora tinha uma nova lei, que, em caso de demandas dessas, tinha de vir um batalhão todo de gente do Governo, p’ra remediarem tudo.”(p. 105-5). Serve-se de expediente ilegal, para fortalecer a adesão do difícil Martinho: "Dei com pedras e cortei com facão, abri um rombo largo no arame... e toquei tudo o que era cavalo e vaca, p’ra dentro da roça.” (p. 105).

No nono e último capítulo do conto, toda a estratégia montada por Lalino é bem-sucedida. No campo familiar, ele reata com Maria Rita, e os espanhóis são 
expulsos; na política, angaria prestígio junto ao Secretário do Interior, que está de passagem na volta a Belo Horizonte, e a vitória do Major é dada como certa.

No caso de sua reconciliação com a mulher, ele é ajudado pela desastrada investida de Oscar para conquistá-la. O filho do Major, mal-sucedido nessa empreitada amorosa, procura minar a reputação de Lalino junto ao pai, por meio de lisonjas e certamente com auxílio de mentiras, sem se importar com o dano que esse ato ocasionaria na campanha política que se desenrolava. Essa faceta do caráter de Oscar completa a imagem de homem de personalidade apagada e, talvez por isso mesmo, invejoso e irresponsável que vai sendo construída ao longo do conto . Mas - e aí reside a tragédia do sistema - Oscar é o futuro Anacleto, de quem herdará as terras, os bens e a posição social de comando.

Lalino, por seu turno, atinge o ponto mais alto da falta de escrúpulos ao induzir o filho de Benigno a desonrar a filha mais nova de Cesário, fazendo que este, como conseqüência, passe de inimigo a correligionário do Major: “- Foi porque o filho do seu Benigno, o Nico (...) que desonrou a filha mais nova do seu Cesário...Os parentes estão todos reunidos, falando que tem de casar, senão vai ter morte... (...) Seu Cesário vai vir aqui, p’ra combinar paz com o senhor, seu Major meu padrinho!” (p. 109).

Lalino, como dissemos, é associado ao sapo, e neste capítulo o narrador insere um coro dos sapos espertos, como o protagonista, que não querem saber de arcar com o trabalho de criação dos filhos do sapo-rei moribundo, função da qual não se extrai nenhum proveito pessoal imediato, mas aceitam a sua mulher, pelo prazer de usufruí-la. A passagem é uma figura das atitudes dos políticos - generalizadas a partir da coletivização do sapo - que pervertem as suas atribuições de prestar serviço aos indivíduos da nação e se aproveitam dessa mesma nação para usufruí-la, em benefício próprio, como se fora uma mulher.

E, no brejo, os sapos coaxavam agora uma estória complicadíssima, de um sapo velho, sapo-rei de todos os sapos, morrendo e propondo o testamento à saparia maluca, enquanto que, como todo sapo nobre, ficava assentado, montando guarda ao próprio ventre.

- “Quando eu morrer, quem é que fica com os meus filhos?”...

- “Eu não... Eu não! Eu não!... Eu não!”...

(Pausa, para o sapo velho soltar as últimas bolhas, na água de emulsão.)

- “Quando eu morrer, quem é que fica com a minha mulher?”

- “É eu! E eu! É eu! É eu! É eu!”...(p.116-7) 
Na sua interpretação de A volta do marido pródigo, Roncari afirma que Lalino é a primeira tentativa de Guimarães Rosa de representar o tipo característico de brasileiro, representação que teria continuidade na figura de Riobaldo. Nesse sentido, o conto guarda com Macunaíma a mesma relação apontada por vários críticos entre Grande sertão: veredas e a obra de Mário de Andrade.

Sob essa perspectiva de Roncari, o próprio nome do protagonista - Eulálio, o que fala muito - já sugere uma característica do brasileiro,

porém num registro satírico, como o proseador, loquaz, aquele que mais fala do que faz, e de cujas palavras temos sempre que desconfiar. Ele não é, entretanto, o falante da incontinência verbal e maçante, dos Caracteres, de Teofrasto, mas um contador nato de casos e patranhas, um artista no sentido popular do termo, de verve natural e espontânea, capaz de encantar e enganar, pelo modo como dá corda à imaginação e ele próprio acaba acreditando na sua prosápia. (RONCARI, 2004, 28-29)

O sobrenome do herói, Salãthiel, remete foneticamente a Satã e lembra também a saudação muçulmana, salam, que significa "paz, salvação”; por outro lado, Salathiel, o filho de Jeconias, é um dos elos intermediários na cadeia genealógica que liga Abrão a Jesus (Mateus, 1, 1-17). Portanto, Salãthiel remete a Deus e ao diabo. (RONCARI, 2004, P. 29). Desse modo, Lalino, personagem caracteristicamente brasileira é, também, e por isso mesmo, uma figura ambígua - ambigüidade expressa por sua condição racial híbrida.

Oliveira Vianna é mencionado por Roncari como a fonte mais importante para entender os traços característicos do protagonista de A volta do marido pródigo associados à sua condição de mulato. Em um de seus Ensaios Inéditos, Oliveira Vianna afirma que "os cronistas coloniais são unânimes em reconhecer na maioria dos mulatos falhas de caráter muito graves.” ( VIANNA, 1991, p. 47) e, ao se referir à psicologia do negro e do índio e de seus cruzamentos com o branco, escreve:

Comparando os mulatos e os mamelucos, sentimos que estes possuem um equilíbrio moral mais perfeito, ao passo que aqueles, embora de caráter menos sólido, parecem mais bem dotados no ponto de vista da inteligência. São mais vivazes, mais curiosos de saber, mais susceptíveis de civilizarem-se, mais destros e ladinos na aprendizagem dos ofícios e mais prontos a imitarem os hábitos e os costumes do homem branco. (VIANNA, 1991, p. 48).

Há, entretanto, a observar: a servilidade, característica do negro, não se transmite ao mulato. Este, ao contrário, é extremamente susceptível e altivo; mas, a sua altivez reveste um caráter altaneiro, cheio de arrogância e insolência, sem esse traço de gravidade e nobreza, próprio à altivez do selvagem e do mameluco. (VIANNA, 1991, p. 49). 
A correspondência entre as idéias de Oliveira Vianna e o protagonista de $A$ volta do marido pródigo foi estabelecida da seguinte forma por Roncari:

Essa teoria explicativa de Oliveira Vianna, que descreve à maravilha o nosso tipo da novela, tem uma correspondência muito grande com os estereótipos criados sobre o mestiço pela visão do preconceito da sociedade escravista. Em nenhum momento Lalino destoa, surpreende, desmente ou coloca em questão essa visão estereotipada. (RONCARI, 2004, p. 32)

A admiração de Lalino por louras estrangeiras e seu repúdio às mulheres negras e mulatas - "Eu nem sei como é que vocês ficam por aqui, trabalhando tanto, p'ra gastarem o dinheirinho suado, com essas negras, com essas roxas descalças...” (p. 77), dirá ele -, além de encerrar fantasias sensuais e de ser fruto da fértil imaginação concebida por Graça Aranha como traço característico do brasileiro que se identifica com a ilusão, com a magia, com a deserção da realidade, como veremos na análise de São Marcos -, contém evidentes traços de racismo. O preconceito do mulato Lalino é, portanto, contra sua raça e contra o negro que entra na sua própria composição racial. $\mathrm{Na}$ análise de $\mathrm{O}$ burrinho pedrês vimos que no Brasil as teorias racistas estrangeiras encontraram em Oliveira Vianna um de seus maiores propagadores e interpretamos o racismo das personagens do livro como uma figura do racismo existente na sociedade brasileira. A volta do marido pródigo, portanto, reproduz sobre o mulato idéias claramente evidenciadas nos discursos das suas personagens - correntes na população e comungadas pelos pensadores que se alinhavam com as idéias raciais de Oliveira Vianna. Sob essa dupla perspectiva, a figura de Lalino se converte na de um mulato típico, tanto no ponto de vista de Oliveira Vianna como no da população brasileira.

O conto, como já dissemos, trata principalmente da prática da política partidária. Rosa demonstrava baixo apreço pelos políticos e pela política em sua entrevista a Gunther Lorenz, ao dizer que a política é desumana, e o político é um imediatista que “pensa apenas em minutos”. Afirma então: "Mas eu jamais poderia ser político com toda essa constante charlatanice da realidade.” (COUTINHO, 1991 p. 77-78).

Que a política é desumana e uma charlatanice da realidade o conto nos diz de modo claro. Ao contrário de Marrinha, Valdemar e Maria Rita, personagens sensíveis e humanas, Lalino, Laudônio e Oscar são incapazes de uma palavra de bondade ou solidariedade humana, de uma expansão de sentimentos positivos. Anacleto mostra alguma compaixão pela filha de Cesário, desonrada por Nico (p. 110), mas o Major é 
tão pouco dotado de discernimento, que a inquietação de sua consciência parece menos derivar de um código moral incorporado no caráter do que da inércia do costume. Afora esse duvidoso gesto de humanidade de Anacleto, os atos das quatro personagens estão voltados exclusivamente para o objetivo de ganhar votos nas próximas eleições, e esse objetivo define a ética que os guia e os papéis sociais que representam. Qualquer preceito moral só é razoável e aplicável se facilitar a consecução de tal objetivo ou, pelo menos, se não ocasionar a perda de votos. E, dos quatro, Lalino é quem demonstra maior competência para obter resultados políticos mensuráveis; é um astuto que não se envergonha de declarar abertamente sua amoralidade a Oscar:

- E os outros, seu Laio? A sociedade tem sua regra...

- Isso não é modinha que eu inventei. (p. 94)

A visão pouco favorável sobre a política brasileira contida na obra pode ser vista em uma passagem do capítulo IX: "No alto, com broto de brilhos e asterismos tremidos, o jogo das estrelinhas esteve completo. Então, o Major voltou a aparecer na varanda, seguro e satisfeito, como quem cresce e acontece, colaborando, sem o saber, com a direção escondida-de-todas-as-coisas-que-devem-depressa-acontecer.” (p. 117-8). Como um tema do conto é a política, o texto pode indicar o determinismo de uma estrutura política retrógrada e sem esperanças de mudança, na qual o indivíduo toma decisões que os apresentam como agentes transformadores da situação social, quando, de fato, eles são seus meros perpetuadores e, desse modo, colaboram "sem o saber, com a direção escondida-de-todas-as-coisas.”

Outra passagem mostra essa mesma visão negativa, agora sobre o ineficiente Estado burocrático brasileiro.:

Major Anacleto relia - pela vigésima-terceira vez - um telegrama do Compadre Vieira, Prefeito do Município, com transcrições de um outro telegrama, do Secretário do Interior, por sua vez inspirado nas anotações que o Presidente do Estado fizera num anteprimeiro telegrama, de um Ministro conterrâneo. E a coisa viera vindo, do estilo dragocrático-mandológico-coactivo ao cabalístico-estatístico, daí para o messiânicopalimpséstico-parafrástico, depois para o cozinhativo-compadresco-recordante, e assim, de caçarola a tigela, de funil a gargalo, o fino fluido inicial se fizera caldo gordo, mui substancial e eficaz; tudo isto entre parênteses, para mostrar uma das razões por que a política é ar fácil de se respirar - mas para os de casa, que os de fora nele abafam, e desistem. (p. 108)

As quatro palavras compostas do período acima, de criação do autor, dão uma visão sobre o Estado burocrático brasileiro de topo à base: “dragocrático-mandológicocoactivo” é uma referência ao exercício do poder pelo Estado e seu monopólio da 
violência legítima, conforme Max Weber: “dragocrático”, o governo do dragão, é possível alusão ao Leviatã, de Thomas Hobbes. "Mandológico” é, etmologicamente, tratado ou estudo do comando e "coactivo" é neologismo derivado de "coactar" e indica o poder de coação do Estado. Em Sezão esse exercício autoritário do poder era mais explícito, “mussolinesco-ideológico-coativo”. Cabalístico-estatístico é uma referência à infinidade de números e dados estatísticos utilizados pelos tecnocratas no funcionamento da máquina do Estado. Messiânico-palimpséstico-parafrástico refere-se aos trabalhos de emissão de papeladas, expedição de documentos, criação de leis, portarias, normas, enfim, a todo o gigantesco aparato administrativo destinado ao uso e à execução de trabalhos burocráticos legais; de fato, "messiânico" é relativo à pessoa por quem se espera com ansiedade, referindo-se às intermináveis esperas a que são submetidos aqueles que necessitam dos serviços de um burocrata; “palimpséstico” dá a noção do arcaísmo da prática do burocrata que atua como um copista da Idade Média a apagar documentos para sobre eles traçar nova escrita; e "parafrástico" diz respeito às explicações sem fim desenvolvidas em textos de documentos pelo mesmo burocrata - e à sua falta de imaginação, que só parafraseia ao produzir texto prolixo e supérfluo e que faz diluir o conteúdo do texto sobre que versa (HOUAISS, 2001). Cozinhativocompadresco-recordante refere-se ao jogo de influências de caráter privado parentesco, amizade, compadrio, apadrinhamento e outras do gênero - exercido nos processos burocráticos para obter privilégios, postergações ou antecipações, etc. Como se vê, a passagem mostra um gigantesco sistema fortemente hierarquizado e pouco produtivo. Roncari assim interpretou a passagem:

Esse telegrama deixava transparecer em si, como num palimpsesto, uma série de outros anteriores, dos quais ele era o resultado rarefeito. O que ele descreve é um sistema essencialmente verticalizado de mando e pressão que vem de cima para baixo, da instância federal, a do Ministro, até a local, a dos pequenos coronéis, passando pela do Presidente do Estado, através do Secretário do Interior, e pela do Prefeito. Nesse sistema, cada etapa compreendia uma esfera própria, que só se relacionava com as imediatamente superior e inferior, tendo cada uma também o seu discurso próprio, que refletia o poder de pressão que tinha sobre as de baixo e o grau de subordinação ou de resistência que vivia com relação às de cima. Na passagem de uma esfera a outra, os novos telegramas procuravam deixar os anteriores apenas subentendidos, de modo que só poderiam ser percebidos muito palidamente, mas que o Major se esforçava para adivinhá-los e decifrá-los, daí as suas inumeráveis leituras. (RONCARI, 2004, p. 19).

Como o conceito negativo sobre a política expresso em Sagarana se aproxima razoavelmente da visão que o autor nos transmite nas suas próprias declarações, parece 
razoável afirmar que a visão da política que se evidencia no conto é a do autor sobre o tema, talvez formada a partir de seu desempenho profissional em funções que lhe propiciaram o convívio com representantes da classe política.

Roncari discorre sobre o contraste entre a atividade política de Lalino, regida pela cordialidade, e a visão dessa atividade no pensamento clássico. Transcrevemos abaixo um trecho da Ética a Nicômano, de Aristóteles, que trata da política; ele serve para ratificar essa assertiva de Roncari:

Ora, como a política utiliza as demais ciências e, por outro lado, legisla sobre o que devemos e o que não devemos fazer, a finalidade dessa ciência deve abranger as das outras, de modo que essa finalidade será o bem humano. Com efeito, ainda que tal fim seja o mesmo tanto para o indivíduo como para o Estado, o deste último parece ser algo maior e mais completo, quer a atingir, quer a preservar. Embora valha bem a pena atingir esse fim para um indivíduo só, é mais belo e mais divino alcançá-lo para uma nação ou para as cidades-Estados. Tais são, por conseguinte, os fins visados pela nossa investigação, pois que isso pertence à ciência política numa das acepções do termo. (ARISTÓTELES, 1973, p. 249-50).

Roncari refere-se também ao pensamento de Platão, sempre com o objetivo de estabelecer o contraste entre os preceitos do filósofo sobre a política e a forma como Lalino a pratica:

Não pensava de outro modo Platão, para quem, a aquisição do que viria a ser chamado posteriormente de "espírito público” era um elemento essencial do processo de educação e de formação do sujeito: “A primeira verdade difícil de ser reconhecida consiste em admitir que a verdadeira arte política necessariamente zela pelo interesse público e não pelo privado, isto porque o interesse público aglutina os Estados enquanto o privado os rompe, e perceber também que beneficia tanto o interesse público quanto o privado igualmente quando o interesse público, mais do que o privado, é bem promulgado”. (RONCARI, 2004, p.52).

Para Lalino, o sentido da política é o inverso do sentido dado pelos pensadores mencionados, ou seja, tem o sentido da realização dos interesses pessoais. Na segunda edição de Sobrados e mucambos, de 1951, depois da publicação de Sagarana, Gilberto Freyre associou o mulato estreitamente à cordialidade: “A simpatia à brasileira (...) o "homem cordial” a que se referem os Srs. Ribeiro Couto e Sérgio Buarque de Holanda essa simpatia e essa cordialidade transbordam principalmente do mulato.” (FREYRE, 1951, p. 1059, apud RONCARI, 2004, p. 34). Lalino é um especialista nas regras que regem a cordialidade. Por exemplo, alardeia ardorosa fé religiosa junto ao vigário - e 
nada no conto indica que ela seja sincera - para obter apoio à sua causa pessoal e à campanha do Major. O Major, por sua vez, atendendo à sugestão de Lalino, que vê risco na aproximação entre o oposicionista Benigno e o pároco situacionista, não só faz exibição de fé, como se confessa e ainda presenteia ao vigário com leitoa, cargo político, dinheiro e madeiras para a obra da capelinha do Rosário. Tio Emílio, em Minha gente, também se aproveitará da religião para tirar vantagens em sua campanha política.

O êxito da aproximação de Lalino com os três membros do governo é peça primorosa das práticas da cordialidade:

- Ah, que honra, mas que minha honra, senhor Doutor Secretário do Interior!... Entrar nesta cafua, que menos merece e mais recebe... Esteja à vontade! Se execute! Aqui o senhor é vós... Já jantaram? Ô, diacho... Um instantinho, senhor Doutor, se abanquem... Aqui dentro, mando eu - com suas licenças - : mando o Governo se sentar... P'ra um repouso, o café, um licor... O mano Laudônio vai relatar! Ah, mas Suas Excelências fizeram boa viagem?...

Mas, não: Suas Excelências tinham pressa de prosseguir. O cafezinho, sim, aceitavam. Viagem magnífica, excursão proveitosa. Um prazer, estarem ali. E o titular sorria, sendo-se o amistoso de todos, apoiando a mão, familiar, no ombro do Major. Ah, e explicava: tinha recebido o convite, para passar pela fazenda, e não pudera recusar. O senhor Eulálio - e aqui o Doutor se entusiasmava - abordara o automóvel, na passagem do rio. O que fora muito gentil da parte do Major, haver mandado o seu emissário esperá-los tão adiante. E, falando nisso, que magnífico, o Senhor Eulálio! Divertira-os! O Major sabia escolher os seus homens... Sim, em tudo o Maior estava de parabéns... E, quando fosse a Belorizonte, levasse o Eulálio, que deveria acabar de contar umas histórias, muito pândegas, da sua estada no Rio de Janeiro, e cantar uns lundús...

Tomado o café, alegria feita, cortesia floreada, política arrulhada, e o muito mais o estilo, o sistema, - o tempo valera. Daí, se despediam: abraço cordial, abraço cordial...(p. 116)

\section{Roncari analisou essa passagem como descritiva dos}

costumes que impregnavam uma ética social: as formas de tratamento das visitas, a hospitalidade, a atitude submissa diante dos superiores, as mostras de intimidades, como os tapinhas nas costas para quebrar as distâncias e estabelecer maior familiaridade. Tudo isso é condensado no termo mais que significativo "sistema", que aparece ali como uma palavra gratuita, colocada meio por acaso e sem grande importância, mas que pode referir-se também à cordialidade como formando um "sistema”. Essa alusão, entretanto, é ambígua e pode ser interpretada tanto como algo organizador e viciante de uma realidade histórica específica, quanto como simples sinônimo de estilo ou traços comuns de comportamento sem maiores conseqüências. (RONCARI, 2004, p. 38). 
Se a personagem Lalino tem as características pessoais que a sociedade brasileira considera típicas do brasileiro médio - a começar pela hibridez racial -, sua cordialidade assume a feição de caráter genérico da nacionalidade brasileira. Lalino é personagem cordial e, por isso, é um protótipo do político brasileiro, também cordial, para o qual os limites das esferas pública e privada são mutáveis e flexíveis, portanto indefinidos. Se assim é, podemos concluir que a visão sobre a política brasileira expressa nesse conto é desalentadora e parece confirmada nas declarações do autor a Gunther Lorenz. Sérgio Buarque de Holanda e Oliveira Vianna tinham visão igualmente negativa sobre o assunto, como vimos na análise de $O$ burrinho pedrês. As ações de Lalino na política são tão amorais quanto no amor, mas é justamente a amoralidade que garante seu êxito político e, como conseqüência direta desse êxito, lhe garante reaver sem dispêndio a mulher vendida. A relação familiar vivida pela personagem funciona como uma representação figurada da sua prática política, e o conto torna-se uma análise profunda dessa prática, ao mesmo tempo em que não deixa de trazer alguns interessantes aspectos sobre a família.

Quando interpretamos $O$ burrinho pedrês vimos que as manifestações violentas de animais e plantas em Sagarana comportam duas formas de interpretação complementares, uma literal e uma metafórica. Em A volta do marido pródigo, a passagem abaixo é a única na qual a natureza é mencionada:

Toma a trilha da beira do córrego. Mas, que lindeza que é isto aqui! Não é que eu não me lembrava mais deste lugar?!

Somente a raros espaços se distingue a frontaria vermelha do barranco. O mais é uma mistura de trepadeiras floridas: folhas largas, refilhos, sarmentos, gavinhas, e, em glorioso e confuso trançado, as taças amarelas da erva-cabrita, os fones róseos do carajuru, as campânulas brancas do cipó-de-batatas, a cuspideira com campainhas roxas de cinco badalos, e os funis azulados da flor-de-são-joão. (p. 92)

As trepadeiras, que tanto encantam o herói, têm relação com a atuação da personagem na vida pública; aplica-se aí a conotação de derivado do verbo "trepar”, sinônimo de "subir”, “alçar-se”, “elevar-se”, relacionado à ambição da personagem (Laudelino Freire menciona o sentido de “elevar-se em categoria ou posição”). “Trepar” também significa “difamar”, falar mal”, conotação que bem se adapta aos recursos utilizados por Lalino como cabo eleitoral. Lalino sensibiliza-se diante da beleza da natureza que só pode ser apreciada por um observador sensível; mas, como prática política e sensibilidade são, de modo geral, incompatíveis - a menos que demonstrações de sensibilidade, sinceras ou não, carreiem votos -, concluímos que a 
expansão de sentimentos do narrador em relação à natureza tem também duplo sentido: por um lado, a paisagem que ele aprecia é uma metáfora de seu próprio caráter de homem ambicioso e envolvente, mas que simula ser atraente como uma planta florida aos olhos de quem a observa; por outro lado, tais expansões provêm de um homem que, por ser praticante da política, tem de obrigatoriamente manter seus sentimentos secretos fora do alcance alheio. De fato, as atividades de Lalino na vida pública nada têm de espontâneas, e ele tem o cuidado de não expor publicamente os seus sentimentos, porque tal exposição poderá ser interpretada como fraqueza e explorada politicamente, pondo em risco suas metas nas esferas pública e privada. E é por isso que sua tristeza somente é manifestada no seu canto solitário, quando retorna do Rio de Janeiro:

"Eu estou triste como sapo na lagoa...".

Não, a cantiga é outra, com toada rida:

“Eu estou triste, como o sapo na água suja...” (p. 92).

Ao esconder seus sentimentos pessoais, Lalino representa publicamente um papel, como em um teatro, no qual realidade e ficção ou verdade e mentira mal podem ser discernidas; podemos então compreender sua relação com seu Marrinha como uma forma de mostrar alguma relação com o teatro; essa pode ser a razão pela qual $A$ volta do marido pródigo é o único conto de Sagarana dividido em capítulos; e ao final do capítulo I o narrador diz: "E, aí, com a partida de seu Waldemar, a cena se encerra completa, ao modo de um final de primeiro ato.” (p. 80).

Se as atividades políticas de Lalino constituem o modelo da atividade política brasileira de Sagarana, a representação teatral de Lalino pode ser estendida para toda a prática política brasileira - que também não deixa de ser uma peça de teatro em que reina a "charlatanice da verdade" de que falava o autor - e, para tanto, serve-se da sua fecunda imaginação e capacidade de representação, como vimos. Sob esse enfoque, o exercício da democracia no Brasil, apresentado em Sagarana, adquire feição de “fachada ou decoração externa” e é resultado de uma acomodação aos direitos ou privilégios de uma aristocracia rural e semifeudal. Esta é uma noção ligada à cordialidade brasileira sobre democracia expressa na página 160, no capítulo O homem cordial de Raízes do Brasil que transcrevemos quando analisamos O burrinho pedrês. A política dos governadores de Campos Sales, ao estabelecer um acordo básico de sustentação mútua entre a União e os grupos mais fortes de cada Estado e domesticar a escolha dos deputados, reduzia a democracia praticada durante a Primeira República a uma encenação oficialmente amparada. Essa situação fica clara no texto de $A$ volta do 
marido pródigo e de outros contos de Sagarana. A conversão do sufrágio popular em farsa poderá ser constatada se formos além dos fatos narrados no livro e lembrarmos o ajuste que foi necessário para efetivar a política dos governadores e o modo pelo qual era abertamente infringida a representação popular; a forma de diplomação do deputado eleito pela Câmara era uma das formas mais eficazes de falseamento do resultado das urnas (FAUSTO, 1994, p. 259); uma passagem de Cangaceiros e fanáticos, de Rui Facó, mostra como nas eleições realizadas nos estados era empregado todo tipo de ilegalidade; a passagem relata as condições impostas ao emissário do Governo Federal pelo coronel Horácio de Matos para a pacificação da zona baiana das Lavras Diamantinas, na disputa de 1919/1920: “Serão reservadas duas vagas de deputado estadual e uma de deputado federal para o coronel Horácio de Matos eleger seus candidatos” (FACÓ, 1978, p. 55-6).

Na obra, o êxito na prática da política brasileira, como o de Lalino, pode ser alcançado somente por aqueles que sejam moralmente flexíveis e se orientem para a finalidade prática da manipulação de eleitores. Essa é a razão provável do constante uso do humor e da ironia no conto. Por exemplo, o Major é apresentado como "homem de princípios austeros, intolerante e difícil de se deixar engambelar.”(p. 97). Essa descrição nada tem de real, porque ele é indeciso e fácil de ludibriar, e seus princípios são extremamente flexíveis e mutáveis, conforme as conveniências pessoais e políticas do momento. Na verdade, a descrição corresponde à imagem política do Major que o público recebe e aceita.

A maioria dos contos de Sagarana - como este, A volta do marido pródigo elabora aspectos relevantes das relações familiares na sociedade brasileira. Algumas famílias estão razoavelmente estruturadas, como as de tio Emílio, de Minha gente, e o que se pode deduzir da do major Saulo, de $O$ burrinho pedrês. Durante a narrativa de $A$ hora e vez de Augusto Matraga, a família original de Nhô Augusto, Dionóra e Mimita se desagrega, dando lugar a uma nova família, composta por Dionóra, Ovídio e Mimita, e a uma “família substituta”, a de Nhô Augusto, mãe Quitéria e Serapião. A família de Alexandre e de-Lurdes, em Minha gente, possivelmente também venha a se desagregar após o término do conto. A de Turíbio Todo e Silivana, em Duelo, se desagrega no início do conto. Outras famílias estão desestruturadas quando se inicia a narrativa, e sua destruição ocorre no transcorrer da história, como a de primo Ribeiro, Luísa e primo Argemiro, em Sarapalha. Em vários casos ocorrem traições femininas - como em 
Sarapalha, Duelo, Minha gente, Conversa de bois e A hora e vez de Augusto Matragae masculinas. A família de Lalino, assim como o noivado de Manuel Fulô, de Corpo fechado, são razoavelmente estabilizadas, mas correm o risco de se dissolverem durante a narrativa.

Como regra geral, todas essas relações familiares são pouco coesas e, para parte das personagens, têm importância secundária, uma vez que é frágil o vínculo afetivo com os demais membros do grupo familiar; o objeto de maior afeição de Manuel Fulô, de Corpo fechado, oscila entre sua noiva com quem está prestes a se casar - situação na qual a paixão entre o casal passa, via de regra, pela máxima intensidade - e a mula Beija-Fulô. As traições femininas terminam ou correm o risco de terminar em sangue, mas nesses casos o móbil do crime em geral mais parece o intuito de lavar da honra da ofensa da traição - para seguir e consagrar o costume - do que propriamente o desespero pela perda da mulher amada e pelo conseqüente desmoronamento da estrutura familiar.

Como dissemos ao analisarmos $O$ burrinho pedrês, a maioria das figuras femininas de Sagarana está, de uma forma ou de outra, envolvida em questões amorosas de vários tipos. Esse envolvimento, porém, se mostra muito diversificado. Se Maria Rita é incondicionalmente apaixonada por Lalino, Luísa, de Sarapalha, abandona o marido para seguir um boiadeiro. Silivana, de Duelo, faz um perigoso jogo duplo, arrancando informações das rotas de fuga do marido para repassá-las ao amante, que anda à procura do foragido para assassiná-lo. Maria Irma, de Minha gente, astuciosamente abre caminho para a conquista de Ramiro, ao levar o Primo e a noiva de Ramiro a se enamorarem. Dionóra, de A hora e vez de Augusto Matraga, abandona a família para seguir Nhô Augusto e, casada com este, abandona o marido para seguir o amante, acompanhada pela filha; esta, por sua vez, abandona o novo lar e se prostitui. A mãe de Tiãozinho, de Conversa de bois, trai abertamente, na própria casa, o marido agonizante - pelo menos essa é a visão que o menino tem da relação da mãe com Agenor Soronho. Outras mulheres vivem situações afetivas na obra, mas as aqui mencionadas são suficientes para constatarmos o fato de que essas mulheres poucas coisas têm em comum, a não ser a obediência a uma regra geral, a de não terem participação efetiva nas atividades políticas ou no jogo de poder, o que é esperado em uma sociedade patriarcal. A única exceção, que confirma essa regra, é a de Don’Ana do Janjão, de Minha gente, da qual trataremos quando estudarmos o conto. Por meio desses exemplos podemos, mais uma vez, provar que a esquematização das personagens do 
autor é apenas aparente, não se encaixando no rígido esquema postulado em Retrato do Brasil: "Desde os tempos primeiros - observa Capistrano -, a família brasileira teve como sustentáculo uma tripeça imutável: pai soturno, mulher submissa, filhos aterrados”. (PRADO, 1999, p. 145). Estas palavras se aplicam para a relação entre Anacleto, Vitalina - que parece ser sua mulher - e Oscar, mas as mulheres submissas de Sagarana são a exceção e não a regra.

Oliveira Vianna em Populações meridionais do Brasil, Caio Prado Junior, em Formação do Brasil contemporâneo, e Maria Sylvia de Carvalho Franco em Homens livres na ordem escravocrata, estabeleceram a distinção entre a família dos donos do poder e a dos homens livres e pobres. Em Sagarana, famílias dos dependentes pobres dos proprietários rurais, como as de Lalino e Maria Rita, a de Turíbio Todo e Silivana, a de primo Ribeiro com Luísa e primo Argemiro, a de Alexandre com de-Lurdes, poucas características têm em comum; no entanto, casos de flexibilidade moral como de Lalino, que vende a mulher que lhe é apaixonada, ou de Turíbio, em cuja relação com Silivana imperam a traição e a mentira, não são encontrados nas famílias de fazendeiros. Estas, por outro lado, tomadas em sua totalidade, apresentam maior faixa de variação de coesão do que as famílias pobres; a qualidade da família de tio Emílio, evidenciada pela tranqüila e afetuosa relação com Maria Irma, de Minha gente, é maior do que a das famílias de Lalino, Argemiro, Turíbio, e outros, mas é contrabalançada pela problemática relação de Anacleto com Oscar ou pela horrível relação familiar de Nhô Augusto com Dionóra e Mimita em A hora e vez de Augusto Matraga. Desse modo, poderíamos inferir que a probabilidade de encontrar no meio das famílias abastadas, como a de Tio Emílio - e talvez a do major Saulo - um ambiente moralmente mais estruturado e favorável ao exercício da liberdade é maior do que nas famílias de seus dependentes econômicos, mas o exemplo de Nhô Augusto mostra que o ambiente no meio familiar de um proprietário rural pode ser pior do que em qualquer família pobre; logo, os limites de moralidade e de imoralidade de um detentor de poder em Sagarana, no que diz respeito às suas relações familiares, são mais amplos do que os limites dos homens pobres. Esse fato não deve surpreender: graças aos bens materiais de que dispõe e ao poder arbitrário que exerce, o patriarca da família abastada tem maiores possibilidades de levar uma vida dissoluta, caso assim o deseje, do que um pobre, porque, além de possuir o dinheiro necessário para realizar seus prazeres, as restrições morais que poderiam contê-lo são estipuladas, ou, pelo menos, endossadas e legitimadas, por ele mesmo, como árbitro da vida social que o poder lhe confere. Os 
limites aceitáveis da moral sexual estabelecida pela tradição e pelo costume são rigorosamente preservados por essa classe social, como pode ser comprovado pela reação de Nhô Augusto que, ao saber da traição da mulher, planeja imediatamente matá-la, junto com o amante.

Essas diferenças de qualidade das relações entre famílias de fazendeiros e famílias pobres não são significativas o suficiente para estabelecer a dependência direta entre coesão familiar e estrato social. Como dissemos, a necessidade econômica não é mencionada no livro e, portanto, não seria de esperar uma relação linear entre necessidades materiais e falta de coesão familiar; essa relação é, de fato, dialética e complexa e estudá-la implicaria estudar os valores que prevalecem nos diferentes estratos e o modo como eles são retratados em Sagarana; o valor pode ser pessoal, interiorizado, ou meramente social e exterior, imposto pelo meio: o fazendeiro devasso com certeza defenderá os valores da fidelidade e da honestidade que lhe interessa que sejam preservados por seus mandados, embora não os vivencie. Nos meios abastados, a defesa dos valores é mais acirrada porque atrelada à defesa da imagem e do prestígio; nos meios menos abastados, em que a imagem perante a sociedade já está aviltada, a defesa desses valores não exige tanto investimento e pode ser mais débil ou nula. Mas isso também não é regra, porque entre os imigrantes europeus, que passaram por tantas penúrias e viveram em estratos sociais pouco prestigiosos, os valores da honra eram defendidos com unhas e dentes. O assunto é complexo e, pelo que pudemos alcançar, o livro não fornece elementos para um estudo muito mais aprofundado do que fizemos aqui.

Em função de tudo o que dele já escrevemos, concluímos que a figura de Lalino é construída a partir de estereótipos do caráter geral do brasileiro, descritos pelos autores que se ocuparam do estudo da nossa sociedade, principalmente Sérgio Buarque de Holanda: hibridez racial, cordialidade, imaginação, esperteza, sensualidade, flexibilidade moral, baixa coesão familiar, disposição para o emprego da violência. Por outro lado, pelo fato de ser mulato, Lalino se converte, na visão popular e de Oliveira Vianna, também no modelo de seu tipo racial. Mas o narrador de Sagarana introduz quatro mulatos em todo o livro, como observamos na análise de $O$ burrinho pedrês, para justamente mostrar a diversidade de seus caracteres; Francolim, cujos atributos morais são exaltados pelo próprio Major Saulo, sábio no tratamento com os homens, nada tem em comum com o inescrupuloso protagonista de $A$ volta do marido pródigo. Do mesmo 
modo, o exercício da política, da forma como é apresentado neste conto, não pode ser tomado como padrão geral para todas as situações brasileiras. O que o conto nos mostra é que figuras como Lalino ou o estúpido e autoritário Major Anacleto têm grande possibilidade de brilharem na política, mas este fato não invalida que outras formas mais limpas - ou menos sujas - de atuação política sejam ainda assim viáveis. Isso poderá ser comprovado em Minha gente, parente próximo e complemento de A volta do marido pródigo, conto no qual a relação da política com o amor será retomada sob outro prisma e sob conotação um pouco menos negativa. O que o conto parece traduzir é que Lalino é o padrão do político brasileiro bem-sucedido que emprega toda sorte de expedientes - legais, quando possível, ou ilegais, quando necessário - para manter-se no poder e dele arrancar vantagens pessoais. 


\section{SARAPALHA}

Na análise de O burrinho pedrês, definimos o “espírito do Calundú” como sendo a tendência do caráter do brasileiro à melancolia, à nostalgia, ao regresso e, como conseqüência, de reagir ao progresso. Em Sarapalha, o “espírito do Calundú” venceu e reina soberano. O local onde vivem os dois primos, Argemiro e Ribeiro, já foi arraial populoso, “já esteve nos mapas” e teve ferrovia, sinais certos de progresso; mas, agora, o cenário é de desolação e ruínas, a população do local se resume a uma empregada negra e aos dois primos, cuja vida transcorre rotineira e extremamente monótona. Essa monotonia, no entanto, será bruscamente interrompida com a declaração da paixão secreta de Argemiro por Luísa, mulher de Ribeiro. Em torno dessa revelação, que introduz temporariamente algo de novo na metódica vida local, gira a narrativa.

O andamento e o clima da narrativa são resumidos na epígrafe do conto. Nela são expressas as dores do amor e suas companheiras: saudade e tristeza. A interjeição “ai”, mencionada por nove vezes nessa epígrafe, será repetida quatro vezes por Ribeiro e três por Argemiro ao longo da história. O fato de alguém cantar para afogar a tristeza e a saudade - o próprio verbo “cantar” é mencionado de modo explícito - sugere que aqui será desenvolvido o motivo do negrinho de O burrinho pedrês: ${ }^{16}$

"Canta, canta, canarinho, ai, ai, ai...

Não cantes fora de hora. ai, ai, ai.,.

A barra do dia aí vem. ai, ai, ai...

Coitado de quem namora!...”

(O TRECHO MAIS ALEGRE, DA CANTIGA MAIS ALEGRE, DE UM CAPIAU BElBA-RIO) (p. 119)

Ao lado do desenvolvimento das idéias que podemos extrair do caso do negrinho, Sarapalha traz ainda outros aspectos presentes em O burrinho pedrês: os dois contos transcorrem em um único dia - embora não sejam os únicos a guardarem essa característica em Sagarana, porque o mesmo sucede com Conversa de bois; o

\footnotetext{
${ }^{16}$ Na música sertaneja brasileira, tristeza e saudade são temas freqüentes. Vejam - se abaixo, por exemplo, alguns dos versos do Tristezas do Jeca, de Angelino de Oliveira, gravada pela Odeon em 1926 em que o sabiá é mencionado por seu canto triste:

Nestes versos tão singelos / minha bela, meu amor, / p'ra você quero contar / o meu sofrer e a minha dor. / Eu sou como o sabiá, / quando canta é só tristeza, / desde o galho onde está. / Nesta viola eu canto e gemo de verdade. / Cada toada representa uma saudade.

Vou guardar minha viola, / já não posso mais cantar. / Pois o Jeca quando canta, / dá vontade de chorar. / E o choro vai caindo, / devagar vai se sumindo / como as águas vão p’ro mar. / Nesta viola eu canto e gemo de verdade. / Cada toada representa uma saudade.
} 
entrelaçamento entre fábula e realidade que ocorre em $O$ burrinho pedrês também ocorre na história narrada por Primo Argemiro sobre a moça levada no rio pelo capeta história que se relaciona diretamente com a de Luísa, levada pelo boiadeiro de Iporanga, na qual o rio serve como fonte de desventura para os dois primos, da mesma forma que o córrego da Fome o é para os que nele se afogam. A mulher, como origem do embate entre dois homens, também é comum aos dois contos, embora essa situação conflituosa seja a regra e não a exceção em Sagarana, como já dissemos; o vau da Sarapalha se parece com aquele atrasado fim de mundo de Goiás no qual Saulinho ia buscar seus bois doentes em $O$ burrinho pedrês e para onde o negrinho queria reconduzi-lo de volta. Ao contar aquele caso, Manico, na passagem já transcrita - “- Pois era uma gentinha magra mesmo héctica” etc. - fala de boi doente, raquítico, feio, porém bravo, que o leitor de imediato relaciona com Primo Ribeiro.

Em Sarapalha, lemos já nas suas primeiras linhas, tudo está em ruínas. “As terras não valiam mais nada.” (p. 120), tudo é decadente. "Morcegos das lapas se domesticaram na noite sem fim dos quartos, como artistas de trapézio, pendentes dos caibros.” (p. 120). O local é uma ilha de sofrimento, circundado por bons homens e bons locais para o cultivo e criação. De seus três habitantes, uma negra é a única que trabalha:

Tapera de arraial. Ali, na beira do rio Pará, deixaram largado um povoado inteiro: casas, sobradinho, capela; três vendinhas, o chalé e o cemitério; e a rua, sozinha e comprida, que agora nem mais é uma estrada, de tanto que o mato a entupiu.

Ao redor, bons pastos, boa gente, terra boa para o arroz. E o lugar já esteve nos mapas, muito antes da malária chegar. (p. 119)

É aqui, perto do vau da Sarapalha: tem uma fazenda, denegrida e desmantelada; uma cerca de pedra-seca, do tempo de escravos; um rego murcho, um moinho parado; um cedro alto, na frente da casa; e, lá dentro, uma negra, já velha, que capina e cozinha o feijão. Tudo é mato, crescendo sem regra; mas, em volta da enorme morada, pés de milho levantam espigas, no chiqueiro, no curral e no eirado, como se a roça se tivesse encolhido, para ficar mais ao alcance da mão. (p. 120-1).

Primo Ribeiro, proprietário da fazenda que já foi próspera, e Primo Argemiro, “os dois velhos - que não são velhos” (p. 122), estão também física e economicamente arruinados: O primeiro "parece um defunto-sarro de amarelo na cara chupada, olhos sujos, desbrilhados, e as mãos pendulando, compondo o equilíbrio, sempre a escorar dos lados a bambeza do corpo. (...) Baba, baba, cospe, cospe, vai fincando o queixo no peito.” (p. 123). Primo Argemiro “É magro, magríssimo. Chega trôpego, bambo, meio 
curvante.” (p. 135). Primo Ribeiro prefere ser enterrado no cemitério do local que, como ele, deve estar em ruínas: “não deixe me levarem p’ra o arraial... Quero ir, mas é p’ra o cemitério do povoado... Está desleixado, mas ainda é chão de Deus”(p. 126). E em ruínas também está Jiló, o “perdigueiro morrinhento” de Primo Ribeiro, que “despertou e veio fazer festas, dando de rabo, esfregando-lhes nas pernas os calombos das costas, cheias de bernes, que ninguém tem ânimo para catar.” (p. 127).

O vau da Sarapalha é o local de retrocesso ao estado de natureza, no qual impera a luta pela sobrevivência de todos contra todos, com seus corolários, a traição e o perigo. Nesse ambiente, a amizade entre os dois primos soa como uma anomalia que será extinta durante a narrativa. Plantar o milho é uma forma de enfrentar a natureza para evitar que ela tome conta de tudo. O estado de natureza se apresenta, em várias passagens, nas plantas que vão lutando entre si para disputar ruas e prédios contra os quais avançam, como em “A gameleira, fazedora de ruínas, brotou com o raizame nas paredes desbarrancadas.” (p. 120) ou no trecho abaixo:

Aí a beldroega, em carreirinha indiscreta - ora-pro-nobis! ora-pro-nobis! apontou caules ruivos no baixo das cercas das hortas, e, talo a talo, avançou. Mas o cabeçade-boi e o capim-mulambo, já donos da rua, tangeram-na de volta; e nem pode recuar, a coitadinha rasteira, porque no quintal os joás estavam brigando com o espinho-agulha e com o gervão em flor. E, atrás da maria-preta e da vassourinha, vinham urgentes, do campo - ói-ái! - o amor-de-negro, com os tridentes das folhas, e fileiras completas, colunas espertas, do rijo assa-peixe.

Também na paisagem é mostrada a possibilidade da traição pela natureza "Mas é bom não pisar forte naquelas esponjas verdes, que costuma haver uma cisterna profunda, por baixo das folhas dos aguapés.” (p. 120) e entre os animais que brincam e ao mesmo tempo matam-se: “O mosquito fêmea não ferroa de-dia; está dormindo, com a tromba repleta de maldades; somente as larvas, à flor do charco, comem-se umas às outras, brincando com as dáfnias e com as baratas-d’água.” (p. 120). Como dissemos, essas passagens podem ser entendidas também como metáforas da condição humana e, nesta segunda acepção, elas figuram o isolamento consciente - ou mesmo o repúdio dos dois homens de qualquer condição civilizada de vida e servem para evidenciar a perfeita integração física e mental dos dois protagonistas ao estado de retrocesso e de selvageria que reina na natureza local. A morte, o luto, a melancolia envolvem homens e animais e inundam o conto do começo ao fim, enquanto os passopretos se divertem com a essa condição, portadores que são de "luto alegre" (p. 124); adiante veremos que o passopreto é a versão brasileira do corvo, a ave de mau agouro do poema de Poe. 
Em um primeiro momento, os habitantes do vau recorrem a Deus para enfrentar a maleita: “- Talvez que até aqui ela não chegue... Deus há-de...” (p. 119). Depois, nas mãos do acaso: “- Talvez que para o ano ela não volte, vá s’ embora...”(p.120). O recurso às forças do sobrenatural, à magia, tem um sentido religioso prático, e esta é uma das características da religiosidade brasileira apontada por Maria Sylvia de Carvalho Franco em A vontade santa. Esse recurso à força divina representa, por um lado, a ruína da mentalidade dos habitantes e, por outro, uma denúncia da inoperância de um governo que não se empenha em impedir a propagação da doença; de fato, a ação do governo, representada pela chegada do médico ao local, é inadequada, pois este fornece um remédio de efeito temporário, mas não elimina o mosquito portador do mal. O médico é idealista, lutador e desprendido; sua mentalidade é moderna e científica. Sua forma de pensar contrasta com a dos habitantes locais: estes são derrotados, alimentados por esperanças infundadas e crenças em forças sobrenaturais salvadoras, com convicções próprias e erradas sobre a forma de propagação da doença que os fustiga; cria-se no texto a oposição entre a mentalidade de progresso, representada pelo médico, e do retrocesso, representada pelo povo local. O retrocesso vence, porque, sem os recursos que seriam necessários para eliminar o mosquito transmissor da doença, a solução final sugerida pelo médico a todos os habitantes é a da fuga do povoado:

"Ele ajuntou a gente...Estava muito triste...Falou: “- Não adianta tomar remédio, porque, o mosquito torna a picar... Todos têm de se mudar daqui... Mas andem depressa, pelo amor de Deus!”... - Foi no tempo da eleição de seu Major Vilhena... Tiroteio com três mortes..."(p. 127).

Esta breve passagem mostra que, no momento crítico para a população, em que o vau da Sarapalha visivelmente caminha para o aniquilamento, ainda existe, entre os políticos, disposição para a disputa violenta pela posse dos despojos deixados pela doença avassaladora. A passagem também reforça a precariedade da democracia brasileira em Sagarana, a que nos referimos na análise de A volta do marido pródigo: por meio de uma eleição, dá-se roupagem civilizadora e democrática ao Estado, mas lança-se mão da violência como forma de alcançar a vitória nas urnas, ou seja, emprega-se como instrumento de afirmação da civilização a violência privada que deveria ser combatida pelo Estado. E aí reside um dos paradoxos da condição social brasileira: o Estado se converte em uma instituição de fachada legalmente validada por eleições cheias de ilegalidades; e esse mesmo Estado, que deveria ser o detentor legal do monopólio da força para conter o comportamento divergente, assiste passivamente à 
prática da violência privada dos chefes locais nas disputas eleitorais que darão aparência de democracia a esse mesmo Estado omisso.

Getúlio Vargas combateu tenazmente a maleita, investindo em médicos e técnicos experientes e eliminando diretamente os mosquitos portadores do vírus. Desse modo, o conto, ao apontar o descaso de governo da Primeira República, está também, indiretamente, mostrando a disposição e a eficácia do governo getulista no combate à doença. Prova a importância da doença em Sagarana e na vida brasileira o fato de ser Sezão, febre da maleita, o título dado originalmente por Guimarães Rosa ao livro que viria a ser depois Sagarana; aquela primeira versão era aberta pelo conto Sezão, que correspondia ao Sarapalha de Sagarana. A maleita e outras doenças tropicais são temas da literatura da época: Inocência de Taunay e Maleita de Lúcio Cardoso estão entre as muitas obras que, de uma forma ou de outra, abordam a maleita como condição catastrófica de vida das personagens. Este último, em especial, também faz referência a uma epidemia de varíola em Pirapora, às margens do São Francisco, ao mesmo tempo em que retrata a luta entre as forças do progresso a as do retrocesso (CARDOSO, 2005), tema presente em alguns dos contos de Sagarana, entre os quais Sarapalha.

A figura do doutor, ao mesmo tempo em que possibilita uma visão social da obra, também estabelece, em um parágrafo, importante conexão entre a mulher e a maleita; ele dá à doença uma dimensão estética, a estética do grotesco, pois em seus delírios provocados pela febre vê a maleita travestida de linda mulher; Primo Ribeiro, no mesmo parágrafo, associa a maleita e Luísa.

- A moça que eu estou vendo agora é uma só, Primo. Olha!... É bonita, muito

bonita. É a sezão. Mas não quero... Bem que o doutor quando pegou a febre e estava variando disse... você lembra?... disse que a maleita era uma mulher de muita lindeza, que morava de noite nesses brejos, e na hora da gente tremer era quem vinha e ninguém não via que era ela quem estava mesmo beijando a gente...(p. 134).

Cleusa Rios P. Passos identificou, com propriedade, Luísa à maleita. Após falar da ambivalência que percorre toda a narrativa no que diz respeito à doença e à personagem, diz Passos: "Paralelamente, doença e mulher se tocam naquilo que engendram, isto é, abandono, desamor e morte, responsáveis pela destruição dos que insistem em ficar. A esterilidade dominante se faz conseqüência do feminino, de sua ausência literal ou presença metafórica.” (PASSOS, 2000, p. 192). A mesma autora fala, mais adiante, sobre o caso da moça que foge de canoa com o capeta vestido de moço bonito com viola enfeitada de fitas: "Luísa se insere em uma tradição que, através dos 
séculos, identifica a mulher como agente de Satã, tendo larga história e transformação cultural” (PASSOS, 2000, p. 196)

Os desvarios de Primo Ribeiro - nos quais sezão, moça bonita, Luísa e maleita se confundem e se equiparam -, o prazer que ele sente na dor, a identificação da mulher com o mal, o sentimento permanente de culpa de Primo Argemiro, além de outros elementos do conto, sugerem a existência de um estrato psicológico em Sarapalha, cuja abordagem apresenta interesse para esta análise. O caso desse conto não é único, pois Guimarães Rosa em algumas ocasiões utilizou-se de idéias extraídas da psicanálise, como, por exemplo, na novela Buriti, de Corpo de Baile. Os conceitos psicanalíticos e sociais de Freud já foram e serão mostrados também em outros contos de Sagarana, como veremos.

O aspecto psicológico de Sarapalha pode ter outras abordagens além da psicanalítica, mas esta nos parece apropriada, porque o emprego dos conhecimentos da psicanálise foi de certa forma usual entre os escritores modernistas, conforme comentado por Antonio Cândido e José Aderaldo Castello: "Na análise psicológica, no lirismo, aprofundaram-se com um senso do que há no homem de infantil, mas também de complicado, utilizando as sugestões da psicanálise, do surrealismo e da antropologia.” (CÂNDIDO e CASTELLO, 1983, p. 11). Eduardo Jardim fala do emprego da linguagem de Totem e tabu de Freud, tanto no "Manifesto antropofágico" como em muitos dos textos jornalísticos de Oswald de Andrade. (MORAES, E. J., 1978, p. 41). O próprio Guimarães Rosa admite influência de Freud em sua obra, na entrevista a Gunther Lorenz: “Amo Goëthe, admiro e venero Thomas Mann, Robert Musil, Franz Kafka, a musicalidade de pensamento de Rilke, a importância monstruosa, espantosa de Freud. Todos estes autores me impressionaram e me influenciaram muito intensamente, sem dúvida” (COUTINHO, 1991, p. 87-8).

O erotismo presente em Sarapalha é um dos aspectos que sugerem uma interpretação psicanalítica. Esse erotismo foi observado por Passos, para quem “Devoração, sedução e uma espécie de êxtase interagem, o inseto ganha traços de mulher, sua música remete à pulsão invocante e a certo 'gozo"”. E, mais à frente: “Conquistando o corpo, a enfermidade parece substituir o prazer perdido com a partida de Luísa”. (PASSOS, 2000, p. 192). Os sintomas da própria maleita chegam como uma mulher: “Ei, Primo, aí vem ela... - Danada!... - Olh’ele aí... o friozinho nas costas...” (p. 122). 
O prazer experimentado por Primo Ribeiro pela presença imaginada do pernilongo pampa, que serve como substituto daquilo que deveria ser o sofrimento da zoeira, tem também uma conotação poeticamente erótica, como observado no parágrafo abaixo:

Mas, se ele vem na hora do silêncio, quando o quinino zumbe na cabeça do febrento, é para consolar. Sopra, aqui e acolá, um gemido ondulado e - sem pouso... Parece que se ausenta, mas está ali mesmo: a gente chega a sentir-lhe os feixes de coxas e pernas, em linhas quebradas, fazendo cócegas, longas, longas... Arrasta um fio, fino e longínquo, de gonzo, fanho e ferrenho, que vem do longe e vai dar no longe... Estica ainda mais o fiapo amarelo de surdina. Depois o enrola e desenrola, zonzo, ninando, ninando... E, quando a febre toma conta do corpo todo, ele parece, dentro da gente, uma música santa, de outro mundo. (p. 121-2).

É evidente a carga sensual da passagem "a gente chega a sentir-lhe os feixes de coxas e pernas, em linhas quebradas, fazendo cócegas, longas, longas”. Freud em seu Três ensaios sobre a teoria da sexualidade faz duas referências à conotação sexual do prurido. No capítulo $O$ alvo sexual infantil, ele associa o prurido à excitação erótica experimentada pela criança na lactância (FREUD, 1989, vol VII, p. 172) e no capítulo $O$ retorno da masturbação da lactância, menciona o prurido como uma forma de satisfação masturbatória infantil. (FREUD, 1989, vol VII, p. 177).

A zoeira no ouvido de Primo Ribeiro, sensação normalmente desconfortável, é assimilada a um canto harmonioso e prazeroso que será executado pelo pernilongo pampa. Ambos, zoeira e canto dos pernilongos, são poeticamente descritos pelo narrador graças à musicalidade de um período que culmina com o emprego de dois heptassílabos: "Enquanto as fêmeas sugam, todos os machos montam guarda, psalmodiando tremido, numa nota única, em tom de dó. E, uma a uma, aquelas já fartas de sangue abrem recitativo, esvoaçantes, uma oitava mais baixo, em meiga voz de descante, na orgia crepuscular.” (p. 121). O tom de dó da cantilena dos pernilongos é, ao mesmo tempo, uma referência ao estado penoso das personagens. A relação entre dor e prazer e a possibilidade da existência do sofrimento no indivíduo como fonte de prazer - como se observa em Primo Ribeiro nessa e em outras passagens do conto que serão mostradas adiante - foi apontada por Freud, em seu O problema econômico do masoquismo, de 1924. (FREUD, 1976, Vol XIX). A epígrafe de Sarapalha, uma lamuriante cantiga de amor, mas, que ainda assim, é "o trecho mais alegre, da cantiga mais alegre, de um capiau beira-rio”, já traz embutida a mesma noção de prazer no sofrimento. Em outra passagem, o narrador afirma que "Primo Ribeiro dormiu mal e o 
outro não dorme quase nunca. Mas ambos escutaram o mosquito a noite inteira. E o ano-felino é o passarinho que canta mais bonito, na terra bonita onde mora a maleita.” (p. 121), que evoca simultaneamente, na mente das personagens, a beleza das ruínas do local e o canto bonito do inseto cuja fêmea transmite a maleita. "Foi bom a sezão ter vindo, Primo Argemiro, p’ra isto aqui virar um ermo e a gente poder ficar mais sozinhos... “ (p. 129). Da mesma forma, em várias passagens, vemos Primo Ribeiro aguardando a morte com ansiedade, como solução almejada de seu sofrimento pela ausência de Luísa: “- A maleita não é nada. Até ajudou a gente a não pensar...” (p. 128); “- Primo Ribeiro, o senhor gosta d' aqui?... - Que pergunta! Tanto faz... É bom, p’ra se acabar mais ligeiro... O doutor deu prazo de um ano... Você lembra?” (p. 126); “Mas, agora, já estou vendo o meu descanso, que está chega-não-chega, na horinha de chegar...” (p. 127); “Quer o remédio, Primo? - Não vou tomar mais... Não adianta. Está custando muito a chegar a morte... E eu quero é morrer.” (p. 129). A ação das mutucas, das muriçocas, do carapanã rajado, do mossorongo e do pernilongo pampa (p. 121-22) é revestida de beleza pela descrição poética que lhe é dada, o que faz do texto uma forma representativa do efeito prazeroso da ação dos insetos sobre as personagens. ${ }^{17}$ Contudo, é no caso contado por primo Argemiro, do "moço-bonito que apareceu, vestido com roupa de dia-de-domingo e com a viola enfeitada de fita... E chamou a moça p'ra ir se fugir com ele” (p. 133) que o impulso masoquista de Primo Ribeiro é mais bem demonstrado. O moço bonito é o capeta, que exerce sobre a moça seu poder de sedução, levando-a em uma canoa pelo rio. A semelhança desse caso com a fuga de Luísa é imediata; no entanto, o próprio Primo Ribeiro se encarrega de fazê-las totalmente coincidentes, ao afirmar que Luísa e o boiadeiro de Iporanga foram para o inferno, a morada do diabo, e que haviam fugido de canoa, quando, na verdade, fugiram de trem: “Foi, rio abaixo, com o outro... Foram p’r'os infernos... - Não foi, Primo Ribeiro. Não foram pelo rio...Foi trem-de-ferro que levou...” (p. 133).

O fato de Primo Ribeiro freqüentemente pedir a Primo Argemiro que conte um caso que ele conhece de memória apresenta dois aspectos, complementares entre si: o primeiro, a de que ele sente enorme prazer no sofrimento trazido pelo relato de um caso que ele associa a um acontecimento que lhe é extremamente doloroso, a fuga de sua mulher com o amante, prazer que tem origem no seu masoquismo. O segundo aspecto

\footnotetext{
${ }^{17}$ Em Sezão, ao compararem o inchaço dos baços, Ribeiro afirma: "Hoje está mais alto... Estou ficando mais importante...”, como se os dois primos estivessem empenhados na vitória em uma competição pelo avanço da doença.
} 
está relacionado com a busca, por Primo Ribeiro, de uma causa inelutável, externa ao casal, para a fuga de Luísa - pois pode justificar-se dizendo que o que fez a mulher fugir não foi vontade desta, mas o capeta, de cujo poder de persuasão até mesmo a primeira mulher foi vítima. Neste caso, ele tem uma explicação inquestionável na esfera social, ao mesmo tempo em que, no âmbito pessoal, alivia a culpa inconsciente de saber-se responsável pela fuga da mulher. Esse estado de culpa inconsciente Freud chamou de "necessidade de punição" (FREUD, 1976, Vol XIX, p. 208) e também o associou à forma de masoquismo que chamou de masoquismo moral.

Em Os instintos e suas vicissitudes, de 1915, Freud fala da reversão do instinto em seu oposto e cita, como exemplo isolado de conteúdo de reversão, a transformação do amor em ódio. (FREUD, 1974, vol XIV, p. 148). Analisa então o par sadismomasoquismo como forma da reversão do instinto em seu oposto, no qual a finalidade ativa de torturar é substituída pela finalidade passiva de ser torturado (FREUD, 1974, vol XIV, p. 148). Em O problema econômico do masoquismo, antes referido, Freud expôs ainda o conceito de que sadismo e masoquismo têm a mesma origem instintual e guardam estreita relação: "pode-se dizer que o instinto de morte operante no organismo - sadismo primário - é idêntico ao masoquismo.” (FREUD, 1976, Vol XIX, p. 205).

Ao mostrarmos a existência de impulsos masoquistas em Primo Ribeiro, a pergunta que nos ocorre, face ao que dissemos sobre a teoria freudiana do sadismo e do masoquismo, é de qual será a contrapartida de sadismo que pode ser nele visualizada. Podemos levantar a hipótese, que a seguir tentaremos fundamentar, de que essa componente de sadismo se manifesta contra Primo Argemiro, no ato de sua expulsão.

Quando o conto se inicia, a afinidade entre os dois primos é de tal ordem, que ambos constroem um código gestual e lexical particular:

E quando Primo Ribeiro bate com as mãos nos bolsos, é porque vai tomar uma pitada de pó. E quando Primo Argemiro estende a mão, é pedindo o cornimboque. E quando qualquer dos dois apóia a mão no cocho, é porque está sentindo falta-de-ar.

E a maleita é a “danada”; “coitadinho” é o perdigueiro; “eles”, a gente do povoado, que não mais existe no povoado; e "os outros” são os raros viajantes que passam lá em-baixo, porque não quiseram ou não puderam dar volta para pegar a ponte nova, e atalham pelo vau. (p. 122).

No entanto, essa relação de amizade tão profunda será bruscamente rompida, porque Argemiro, não suportando o peso do remorso de nutrir pela mulher do primo uma paixão proibida, termina por confessar seus sentimentos a Primo Ribeiro. Ao expulsar Argemiro, Primo Ribeiro encontra a plena felicidade, pois destrói a única fonte 
onde poderia obter algum sentimento de solidariedade que se opunha à realização de seus impulsos masoquistas: “- O senhor ainda pode precisar de mim, Primo, que sou o único amigo que o senhor tem...”, diz Argemiro; “- Então, vai, Primo!...”, responde Ribeiro (p. 136). Graças ao sentido duplo de "sua”, pronome possessivo e presente do indicativo de "suar", vemos Primo Ribeiro exultar com a partida de Argemiro, porque agora Luísa será só sua: “sua, sua, assim corpo e roupa.” (p. 138), ou seja, ele se alegra com o isolamento ainda maior; agora sim, sua solidão é completa, e ele somente viverá em função de recordações e da morte inevitável e tão aguardada. Mas essa atitude masoquista de Primo Ribeiro tem uma contrapartida de sadismo: se, como vimos, para Primo Ribeiro a permanência definitiva na Sarapalha é uma necessidade de realização de impulsos masoquistas, podemos deduzir que, do seu ponto de vista resultante da experiência pessoal, ele conclui que Argemiro também vive a mesma necessidade. Nesse caso, o dano maior que Primo Ribeiro pode infringir a Primo Argemiro é rechaçá-lo do local onde, ainda do seu ponto de vista, Argemiro vive em função da saudade de Luísa. Desse modo, a atitude de Primo Ribeiro visa a infligir ao primo o mesmo dano que ele sofreria se ele, Ribeiro, fosse forçado a abandonar a Sarapalha; assim, a expulsão de Argemiro caracteriza um comportamento sádico de Primo Ribeiro. Por outro lado, seu masoquismo é satisfeito quando ele se mostra inflexível perante as explicações de Primo Argemiro e opta por ficar sem a sua companhia, isolado.

Argemiro é homem de elevadas virtudes morais e, por essa razão, não realiza seu amor ilícito por Luísa; mas vive forte conflito interno entre moral socialmente sedimentada e impulso sexual:

Nesse dia, quase que perdera a força de ser correto. Viu-a de vestido azul-domar... Os braços cor de jenipapo... As mãos deviam de ser macias... Mas Deus ajudou, tirando-lhe a coragem... Também, se tivesse faltado com o respeito à mulher do Primo Ribeiro, teria sumido no mundo, na mesma da hora, com remorso...(p. 131)

... Não adiantou ter sido tão direito... Se ele, Primo Argemiro, tivesse tido coragem... Se tivesse sido mais esperto... Talvez ela gostasse... Podia ter querido fugir com ele; o boiadeiro ainda não tinha aparecido... (...) Não! Fez bem. Era a mesma coisa que crime!... Nem é bom pensar nisso... (p. 132).

O drama de consciência vivido por Primo Argemiro, fruto de seus impulsos sexuais reprimidos, é fonte de fortes sentimentos de culpa e, ao mesmo tempo, de busca de atitudes compensatórias. Essas atitudes acabam por torná-lo subserviente ao primo: “Amanhã ele vai ao capoeirão, tirar mel de irussu para o Primo Ribeiro... Deus que livre a gente desses maus pensamentos!... Primo Ribeiro vai ficar satisfeito: ele gosta de mel 
do mato, com farinha... Primo Ribeiro vai ter sua alegriazinha...” (p. 132). A própria permanência de Primo Argemiro ao lado de Primo Ribeiro é, por um lado, obra desse sentimento de culpa - talvez não conscientemente captado -, embora, por outro lado, pareça ser a forma consciente encontrada por ele para manter viva a lembrança de Luísa. O fato é que o peso dessa culpa é tão grande, que ele chega a desejar a extinção do desejo, no qual seu amor e, por conseqüência, sua culpa têm origem: “- P’ra que é que há-de haver mulher no mundo, meu Deus?!...” (p. 132). Seu amor por Luísa não é essencialmente carnal e instintivo; como afirma Roncari, ele não a demoniza, como faz o primo Ribeiro quando diz que ela e boiadeiro da Iporanga “Foram p'r'os infernos!” (RONCARI, 2007, p. 58); pelo contrário, seu amor é elevado, sublime, romântico ocidental, trovadoresco: é o amor cortês. Em São Marcos Guimarães Rosa exporá três formas de amor. O amor elevado - um desses três tipos definidos pelo autor - é o vivido por Argemiro.

A despeito da afinidade entre os dois primos, Argemiro possui traços de caráter diferentes dos de Primo Ribeiro. Se este é preso ao passado, à inação e encontra prazer no sofrimento e na morte que se aproxima, Argemiro procura afastar pensamentos de morte: “- Mas, então, não fala em morte, Primo Ribeiro!...” (p. 127); ele lamenta a partida do doutor: “Olha aqui: não foi pena ele ter ido s'embora? Eu tinha fé em que acabava com a doença...” (p 127), e tece planos para o futuro, imediatamente rechaçados por Primo Ribeiro: “- Olha, Primo, se a gente um dia puder sarar, eu ainda hei de plantar uma roça, no lançante que trepa para o espigão. (p. 124)

Se, para Primo Ribeiro, a expulsão representa a satisfação de impulsos sadomasoquistas, para Argemiro ela será o início de uma possível caminhada de vida na direção da libertação das amarras da culpa e das lembranças que o prendiam à Sarapalha: "E Primo Argemiro reúne as suas forças. E anda. Transpõe o curral, por entre os pés de milho.” (p. 138). Estabelece-se, nos últimos parágrafos do conto, um conflito interno em Argemiro, com a imagem de Luísa chamando-o em suas recordações e ele tentando ir "para a frente"

Ir, para onde?

...A primeira vez que Argemiro dos Anjos viu Luisinha, foi numa manhã de diade-festa-de-santo, quando o arraial se adornava com arcos de bambu e bandeirolas, e o povo se espalhava contente, calçado e no trinque, vestido cada um com a sua roupa melhor...

Ir para onde!... Não importa, para a frente é que a gente vai... (p. 139) 
Argemiro não quer manter nenhum vínculo com aquilo que está abandonando: “- Ajunta suas coisas e vai... - Não tenho nada... Não careço mais de nada... O que é meu vai aqui comigo... Adeus!”; “Mas Primo Argemiro anda sem se voltar.” (p. 138). Jiló, o perdigueiro, não sabe a qual dos dois primos acompanhar, mas Argemiro, mais uma vez, rompe os vínculos que o prendem e se mostra indiferente à indecisão do cão: “Fica. Ninguém não mandou que ele fosse embora... Ele pode ficar...” (p. 138). Os passopretos, integrados na paisagem melancólica e funérea, agora o vêem como um estranho ao meio e se afastam à sua passagem: “ao verem um espantalho caminhando, debandam, bulhentos”. (p. 138).

A despeito de castigado pela doença, Argemiro vê a beleza do mundo e, fundindo-se nesta, a beleza de Luísa. E ele que, presa da paixão que cega, antes a via de grande beleza - “Morena, os olhos muito pretos... Tão bonita!...” (p. 130); “Esquisita, sim que ela era... De riso alegrinho mas de olhar duro... Que bonita!...” (p. 130) -, agora tem a lucidez de enxergá-la em sua dimensão real e pode perceber que "Talvez que ela não fosse a moça mais bonita do arraial... E não era mesmo. Mas o amor é assim...” (p. 139) ${ }^{18}$. Já Ribeiro vive uma situação ilusória, que o leva a criar uma imagem idealizada de Luísa, associando-a, em seu delírio provocado pela febre, a mulheres que não são tentadas a cometer adultério, pois não têm olhos para os homens e não exercem sedução, porque estão vestidas de cor de água: “- É... passa... passa... passa... Passam umas mulheres vestidas de cor de água, sem olhos na cara, para não terem de olhar a gente... Só ela é que não passa, Primo Argemiro!... E eu já estou cansado de procurar, no meio das outras.” (p. 133).

Na partida de Argemiro, o céu é mencionado pela primeira vez no conto como sua morada futura, onde experimentará a felicidade de reencontrar Luísa. Seus princípios morais orientam suas fantasias e nelas ele preserva o amor de Luísa pelo boiadeiro e o direito do marido sobre a mulher: “Quando a verá ainda?!... No Céu, talvez... Mas, mesmo no Céu, ela terá que gostar do boiadeiro da Iporanga... E ele, Argemiro, terá de respeitar Primo Ribeiro, que é o marido em nome de Deus...” (p. 139). Mas, em seguida, inverte mais uma vez sua vontade, quer afastar-se

\footnotetext{
${ }^{18}$ Em Sezão, há uma referência interessante aos olhos da prima, como de um animal traiçoeiro, o que nos faz vir à memória os olhos de Capitu:

Aquilo tinha sido três meses antes de ela fugir. Mas, antes, bem em- antes disso, teve uma vez que ela desconfiou. Foi logo que ele chegara à fazenda, uns dias depois. Estava olhando, assim esquecido, para os olhos... olhos grandes, escuros e meio de-quina, como os de uma suassuapara... para a boquinha vermelha, como flor de suinã...(ROSA, J. G., 1937, p. 13)
} 
definitivamente de Luísa e, para consegui-lo, prefere que o céu não exista de verdade: "Nunca mais? Nunca mais... Ai, meu Deus! por mim era muito melhor não ter céu nenhum...” (p. 139) A partir desse momento ele recupera sua identidade perdida e agora não é só Argemiro, mas Argemiro dos Anjos (sobre a revelação da identidade dos personagens do livro discorreremos em Duelo). Essas referências a anjos - que estão no nome da personagem - e ao céu como morada definitiva dos humanos sugere a possibilidade de associar a culpa de Primo Argemiro à do cristão que peca e se tortura em pensamentos, pois não pecou nem por ações e nem por palavras: “- Não foi culpa minha... Foi um castigo de Deus, por causa de meus pecados. O senhor me perdoa, não perdoa?!...” (p. 136); “- Mas, sossega, Primo Ribeiro... Já lhe jurei que não faltei nunca ao respeito a ela... Nem eu não era capaz de cair num pecado desses...” (p. 137).

Nos últimos parágrafos do conto, a palavra "tremer" determina a fonética do texto, de modo a confirmar o domínio devastador da sezão sobre personagem e natureza. Argemiro sofre então o acesso da sezão, o qual the traz duplo gozo, o da apreciação da beleza da natureza e o dos sintomas da doença, mas o texto não deixa claro se ele morre ou vive:

Ir para onde!... Não importa, para a frente é que a gente vai... Mas, depois. Agora é sentar nas folhas secas, e agüentar. O começo do acesso é bom, é gostoso: é a única coisa boa que a vida ainda tem. Pára, para tremer. E para pensar. Também.

Estremecem, amarelas, as flores da aroeira. Há um frêmito nos caules rosados da erva-de-sapo. A erva-de-anum crispa as folhas, longas, como folhas de mangueira. Trepidam, sacudindo as suas estrelinhas alaranjadas, os ramos da vassourinha. Tirita a mamona, de folhas peludas, como se o corselete de um cassununga, brilhando em verdeazul. A pitangueira se abala do jarrete à grimpa. E o açoita-cavalos derruba frutinhas fendilhadas, entrando em convulsões.

- Mas, meu Deus, como isto é bonito! Que lugar bonito pra gente deitar no chão e se acabar!...

É o mato, todo enfeitado, tremendo também com a sezão. (p. 139-40).

Observemos, agora, que a forma de tratamento dado por Primo Ribeiro a Primo Argemiro - ora de irmão, mas também de filho - retrata uma situação psicanalítica de incesto, não sob a ótica de Primo Ribeiro, mas também para o leitor e para Primo Argemiro, na qualidade de filho que disputa o amor da mulher do pai. Essa relação de parentesco é esquematizada no fato de primo Ribeiro tratar primo Argemiro por “você”, enquanto este trata aquele por “senhor”. No caso, a culpa permanentemente vivida por primo Argemiro seria fruto de seu conflito edipiano, que se resolve quando Ribeiro 
perde a "paternidade" que sobre ele exercia. Existe a possibilidade de as três personagens desse triângulo amoroso serem primos entre si, pois Argemiro se refere à mulher como Prima Luísa (p. 134), mas ele pode ter-se valido dessa forma de tratamento simplesmente por ela ser mulher de seu primo ou para, consciente ou inconscientemente, criar um falso grau de parentesco com o propósito de afastar do primo qualquer suspeita de seu amor por ela. Mas, seja qual for o motivo do emprego dessa forma de tratamento, ele agrava ainda mais a situação incestuosa, porque estabelece um laço de família entre os três. Essa situação perigosa somente será resolvida com a entrada em cena do amante da mulher, que evita o assassínio de um primo pelo outro, altamente provável no futuro. O boiadeiro de Iporanga é, portanto, o mal que veio para o bem, mas, aos olhos de Ribeiro, é o próprio mal, sendo associado ao demônio no caso contado por Primo Argemiro, da moça levada pelo capeta. A relação marital entre primos é perigosa e tem estabilidade precária em Sagarana. Em Minha gente, como veremos, o autor explorará em profundidade o mesmo tema.

Nesta visão psicológica do conto, repetimos, os tormentos das lembranças e culpas de Argemiro são vencidos graças à sua expulsão por Primo Ribeiro. Este, por sua vez, sentindo prazer no sofrimento físico e moral, liberta-se da presença do primo que a ele se dedica com tanto empenho e passa a aguardar a morte solitariamente, em conformidade com seu impulso masoquista.

Retornemos à frase "Nunca mais? Nunca mais... Ai, meu Deus! por mim era muito melhor não ter céu nenhum...” (p. 139). O “nunca mais” não deixa de sugerir uma associação com a passagem ao poema $O$ corvo, de Edgard Allan Poe, na qual “nevermore” é a única palavra pronunciada pela ave que dá nome à obra como resposta a todas as perguntas formuladas pelo estudante que perdeu a amada Lenora; é possível fazer um paralelo entre os passopretos de Sarapalha e o corvo do poeta norteamericano. São vários os pontos de contato de Sarapalha com o texto de Poe; aqui nos deteremos em alguns deles. Para tanto, lançaremos mão do ensaio A filosofia da composição, no qual Poe expõe em minúcias o seu processo de criação de $O$ corvo.

Poe afirma ser o corvo ave de mau agouro (POE, 1999, p. 107), que a morte é o mais melancólico de todos os temas melancólicos, e que, quando esse tema mais melancólico se alia à Beleza, ele se torna o mais poético de todos: “a morte, pois, de uma bela mulher é, inquestionavelmente, o tema mais poético do mundo e, igualmente, a boca mais capaz de desenvolver tal tema é a de um amante despojado de seu amor”. 
(POE, 1999, p. 107). Afirma que o sentimento dominante no poema é o da tristeza e da melancolia, e que "A melancolia é, assim, o mais legítimo de todos os tons poéticos." (POE, 1999, p. 105). A seguir, fala do prazer no sofrimento experimentado pelo amante:

Vi que poderia fazer da primeira pergunta, apresentada pelo amante - a primeira pergunta a que o Corvo deveria responder "Nunca mais" -, que poderia fazer dessa primeira pergunta um lugar-comum, da segunda uma expressão menos comum, da terceira ainda menos, e assim por diante, até que o amante, arrancado de sua displicência primitiva, pelo caráter melancólico da própria palavra, pela sua freqüente repetição e pela consideração da sinistra reputação da ave que a pronunciava, fosse afinal excitado à superstição e loucamente fizesse perguntas de espécie muito diversa. Perguntas cujas respostas lhe interessavam apaixonadamente ao coração, fazendo-as num misto de superstição e daquela espécie de desespero que se deleita na própria tortura, fazendo-as não porque propriamente acreditasse no caráter profético, ou demoníaco da ave (que a razão lhe diz estar apenas repetindo uma lição aprendida rotineiramente), mas porque experimentaria um frenético prazer em organizar suas perguntas para receber, do esperado "Nunca mais”, a mais deliciosa, porque a mais intolerável, das tristezas. (POE, 1999, p. 108).

Finalmente, Poe nos mostra o sentido moral do poema (POE, 1999, p. 113) e diz que "não é senão nos versos finais da última estância que se permite distintamente ser vista a intenção de torná-lo um emblema da recordação dolorosa e infindável” (POE, 1999, p. 113)

And the raven, never flitting, still is sitting, still is sitting

On the pallid bust of Pallas just above my chamber door;

And his eyes have all the seeming of a demon's that is dreaming.

And the lamplight o'er him streaming throws his shadow on the floor;

And my soul from out that shadow that lies floating on the floor

Shall be lifted... nevermore! ${ }^{19}$

Para Vítor Manuel Aguiar e Silva, A filosofia da composição é um texto fundamental da corrente intelectualista do Romantismo literário, (AGUIAR E SILVA, 1968, p. 193). Se em Sarapalha há uma referência a $O$ corvo e ao Romantismo, a pergunta cabível diz respeito à razão dessa referência e à possibilidade de alguma relação significativa com o texto rosiano. Uma razão plausível para a menção poderia ser a qualidade literária de $O$ corvo e, neste caso, estaríamos diante de mais uma das costumeiras alusões a grandes obras da literatura universal no texto de Rosa. Mas, se

\footnotetext{
19 E o corvo, na noite infinda, está ainda, está ainda

No alvo busto de Atena que há por sobre os meus umbrais.

Seu olhar tem a medonha dor de um demônio que sonha,

E a luz lança-lhe a tristonha sombra no chão mais e mais.

E a minh'alma dessa sombra, que no chão há mais e mais,

Libertar-se-á... nunca mais! (Tradução de Fernando Pessoa in PESSOA, 1986, p. 633)
} 
assim é, uma questão deve ser respondida: se em Sarapalha o espírito romântico é criticado - pois que vem associado ao atraso e ao retrocesso -, por que Guimarães Rosa utiliza como referência um poema romântico, no qual imperam a tristeza e a melancolia e em que esses sentimentos são propositadamente exaltados pelo autor?

Como escrevemos quando analisamos O burrinho pedrês, acreditamos que Rosa critique o espírito romântico e o anacronismo do Romantismo do século XX, e não o Romantismo como um período definido da história da humanidade que cultivou a dor e a melancolia. Portanto, podemos arriscar que a menção do poema de Poe pretendia ser da mesma origem das suas alusões a Dante, a Virgílio e a outros autores. Neste caso, a alusão a $O$ corvo funcionaria como uma reiteração de que Sarapalha está tratando das características do espírito romântico e que o conto deve ser lido como uma descrição das ruínas por ele provocadas. A associação do espírito romântico com o atraso social foi estabelecida em O burrinho pedrês e é reforçada em Sarapalha. Por conseguinte, ao estabelecer sua ligação com o retrocesso, a menção do poema de Poe adquire a função de reforçar as idéias sociais de Sarapalha. Mas a alusão tem também outra função, a de clarear o sutil contraste existente entre os caracteres dos dois protagonistas do conto. Com efeito, no poema de Poe o corvo é símbolo da recordação fúnebre; no entanto, os passopretos, correspondentes ao corvo de Poe em Sarapalha, permanecem como companheiros eternos de Primo Ribeiro - como o corvo de Poe se torna eterno companheiro do estudante apaixonado -, mas foge assombrado pela evasão de Primo Argemiro. Esta diferença é fundamental para compreender o sentido da libertação de Argemiro, independente do fato de ele sucumbir ou não no desfecho do conto: ela se realiza pela evasão que o livra do contágio de primo Ribeiro e, metaforicamente, do espírito do retrocesso. Por isso é que ele afirma que “para a frente é que a gente vai” (p. 140)

Em Sarapalha, notamos a repetição do número três e de seus derivados: o conto tem três personagens, os dois primos e a criada, e se situa em um local que possuía "três vendinhas” (p. 119); “Mas, é só andar três quilômetros para cima” (p. 120); “O rio, lá adiante, vê-se agora a três dimensões" (p. 121); "Ficou mudo, espiando as três galinhas” (p. 123); “Tiroteio com três mortes...” (p. 127); “- Só três anos de casados!...” (p. 129); “O boiadeiro tinha ficado três dias na Fazenda” (p. 130-31); “Aquilo tinha sido três meses antes de ela fugir” (p. 131). Esta recorrência de trios, comum nos contos de Sagarana, pode ser entendida como metáfora do triângulo amoroso presente na obra, 
mas pode eventualmente sugerir uma interpretação religiosa do conto. Em sua dissertação de mestrado Passagens bíblicas em Sagarana, de João Guimarães Rosa, Aguinaldo Aparecido Campos afirma que a expulsão de Primo Argemiro por Primo Ribeiro pode ser associada à expulsão de Adão e Eva do Paraíso. Segundo ele, o vau da Sarapalha é, para as personagens, uma espécie de paraíso celeste, cujos habitantes estão em perfeita simbiose com o espaço físico restrito e limitado em que se movimentam. Como Adão, Primo Argemiro é expulso da terra em que vivem por causa de sua paixão proibida pela mulher de seu primo. Primo Ribeiro considerava-o filho: “Também, eu só estou falando é com você, que é p’ra mim que nem um irmão. Se duvidar, nem um filho não era capaz de ser tão companheiro, tão meu amigo, nesses anos todos...” (p. 128); afirma que "Nem um irmão, nem um filho não podia ser tão bom...” (p. 135) e se sente traído como se houvesse sido picado por uma cobra, o animal bíblico símbolo da queda do homem: “- Fui picado de cobra...” (p. 137). Como Adão, Primo Argemiro é fustigado pela culpa e, quando expulso, não sabe para onde ir: "Ir para onde!... Não importa, para a frente é que a gente vai...” (p. 139). No entanto, Argemiro sabe que na morte reencontrará tudo o que perdeu: o primo querido, o local em que habita e que lhe rememora a mulher amada. O caso da moça que fugiu com o diabo disfarçado em "moço-bonito que apareceu, vestido com roupa de dia-de-domingo e com a viola enfeitada de fitas...” (p. 133)... mostra a tentação do diabo à mulher, como no Gênesis.

Se nos inspirarmos na hipótese religiosa formulada por Campos, deveremos responder a que Paraíso corresponde o local onde o conto se desenrola. Na verdade, o vau da Sarapalha, pelo sofrimento físico a que estão submetidos os seres vivos, pela luta incessante dos componentes da natureza e pelo enorme sofrimento mental dos dois primos, mais se assemelha ao inferno na terra; e o espaço ao redor, onde existem "bons pastos, boa gente, terra boa para o arroz” (p.119), parece, este sim, mais próximo do Paraíso bíblico. Ao relacionar o espírito romântico com as forças do atraso, da estagnação, do retrocesso a que foi submetido o local no qual o conto se desenrola, o Paraíso vislumbrado no vau da Sarapalha terá sinal trocado em relação ao Paraíso retratado no Gênesis. Dessa forma, concluiremos que o "espírito do Calundú”, que sintetiza a tendência brasileira à tristeza e à melancolia, segundo Paulo Prado, é a fonte que nos leva a um paraíso em que os brasileiros de espírito romântico - figurados no conto principalmente por Primo Ribeiro - se deleitam com o sofrimento, a saudade e a resistência ao progresso, mas nada tem do Paraíso bíblico nem daquele que foi idealizado pelos conquistadores das Américas, a começar por Colombo, descrito por 
numerosos cronistas da conquista, com menções às próprias palavras de Ovídio sobre a Idade de Ouro. (HOLANDA, 1998, p. 185).

Por tudo o que dissemos, vemos que Sarapalha trata da relação dialética entre a psicologia do caboclo e o meio social no qual atua e ao qual está, ao mesmo tempo, submetido. Essa atenção a uma parcela quantitativamente significativa da população brasileira é fundamental numa obra em que se encontra tão vivaz representação do Brasil; e é devido ao seu peso na população brasileira que a definição dos seus traços psicológicos já havia sido formulada anteriormente por outros autores. Monteiro Lobato criou o Jeca Tatu, caboclo preguiçoso e doente, e as figuras dos dois primos reproduzem com razoável fidelidade a virulenta descrição feita por ele em 1918 no conto Velha praga de seu Urupês, que causou enorme polêmica nas páginas do jornal O Estado de São Paulo. Em Velha praga lê-se:

Este funesto parasita da terra é o CABOCLO, espécie de homem baldio, seminômade, inadaptável á civilização, mas que vive á beira dela na penumbra das zonas fronteiriças. A medida que o progresso vem chegando com a via férrea, o italiano, o arado, a valorização da propriedade, vai ele refugindo em silêncio, com o seu cachorro, o seu pilão, a picapau e o isqueiro, de modo a sempre conservar-se fronteiriço, mudo e sorna. Encoscorado numa rotina de pedra, recua para não adaptar-se. (LOBATO, 1986, p. 141)

Ainda em 1918, graças à convivência com Artur Neiva e Belisário Pena - este, autor de $O$ saneamento do Brasil -, Monteiro Lobato mudaria de opinião sobre o homem da roça; "Está provado que tens no sangue e nas tripas um jardim zoológico da pior espécie", admite agora. "É essa bicharia cruel que te faz papudo, feio, molenga, inerte. Tens culpa disso? Claro que não.” (AZEVEDO, CAMARGOS e SACCHETTA, 1997, p. 112). No mesmo ano, Lobato publica uma série de artigos no jornal O Estado de São Paulo, à qual deu título geral de Problema vital, com artigos intitulados Vinte milhões de opilados, Três milhões de papudos e idiotas, Doze milhões de impaludados, etc. Essa situação levou o acadêmico Miguel Pereira a dizer que o "Brasil é um vasto hospital” (AZEVEDO, CAMARGOS e SACCHETTA, 1997, p. 114-15).

As idéias de Cassiano Ricardo sobre o assunto são opostas às de Monteiro Lobato; no poema Caboclo à hora do descanso, de seu Martin Cererê, de 1928, é como herói que o caboclo é retratado. (RICARDO, 2003, p. 180-1), e a tristeza, como traço de caráter do caboclo, é especificamente mencionada no poema, porém com sentido positivo: "Você o está vendo assim, meio triste, / mas é ele quem pega da viola e quem 
canta / mais bonito que um pássaro na tarde louca / que é um carnaval silencioso de estrelas / brotando de todos os poros da noite.” (RICARDO, 2003, p. 180).

Sarapalha aborda as questões da proverbial preguiça e das doenças físicas e psicológicas do caboclo de um modo diverso tanto de Lobato como de Ricardo. Ao introduzir uma série de sintomas passíveis de interpretação psicanalítica e, ao mesmo tempo, mostrar aspectos sociais que envolvem Primo Ribeiro - no conto tomado como amostra do caboclo médio -, a narrativa nos oferece a possibilidade de visualizar um funesto círculo vicioso ao qual a personagem está submetida: a doença é agravada por um mecanismo psicossomático e, ao mesmo tempo, retroalimenta o masoquismo; por outro lado, a tristeza e a saudade inerentes à sua personalidade de caboclo retroalimentam e agravam a doença e os sintomas que lhe são correlatos: indolência, desânimo, inanição; e tais sintomas, por seu turno, sustentam as forças da estagnação e do retrocesso social que atuam no sentido de retorno ao estado de natureza. Portanto, ocorre um complexo entrelaçamento de vários fatores sociais e psicológicos - doença, tristeza, saudade, estado psicológico, retrocesso, etc. - que constituem um sistema em que cada um se torna, simultaneamente, causa e efeito dos demais. Por outro lado, Argemiro, embora submetido às mesmas condicionantes sociais e psicológicas e maltratado pela mesma doença de Primo Ribeiro, tenta escapar desse círculo vicioso; com esse comportamento, torna-se clara em Sagarana, mais uma vez, a variação de caracteres entre indivíduos de mesma condição social. Visto desse modo, Sarapalha retrata com profundidade a psicologia do caboclo, porque apresenta uma visão sistêmica da complexidade dos múltiplos fatores que a determinam, negando, portanto, que ela possa ser definida por uma relação linear simplista como caracteres congênitos, descaso de governo ou outro fator isolado qualquer; é essa complexidade de múltiplas causas e efeitos que ocasiona a ruína total do vau da Sarapalha e que faz o local retroceder ao estado de natureza.

Uma síntese dos mais significativos aspectos de Sarapalha pode ser vista na ilustração que encerra o conto, na página 147 da $5^{\text {a }}$. edição de Sagarana. Nela, uma mulher, que entendemos seja Luísa, ocupa o centro de

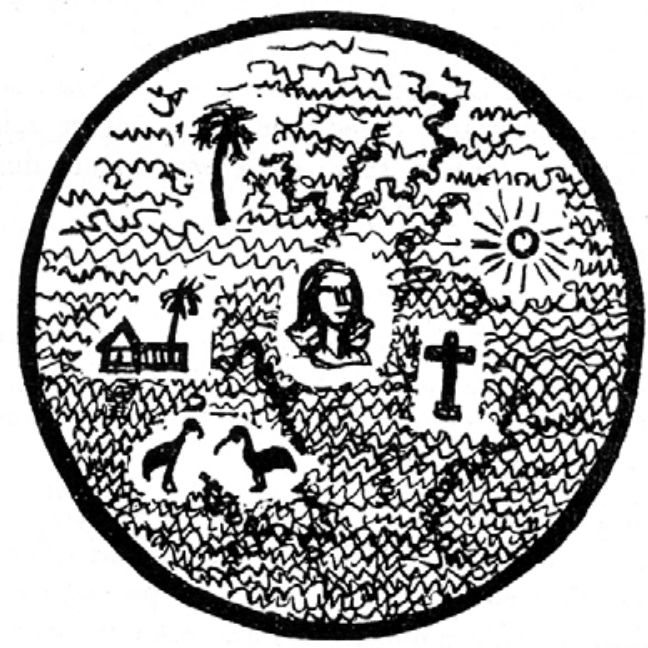


um círculo, dentro do qual também se encontram vários elementos que aparecem no conto: os passopretos, que mais se assemelham a urubus; uma cruz do que parece ser um túmulo, evidente referência à morte que percorre a obra; palmeiras, que lembram saudade e espírito romântico, porque trazem à memória as de Gonçalves Dias; uma construção semelhante a uma casa; e um sol brilhante, deslocado para a direita, mas que, como um olho atento, parece tudo observar. 


\section{DUELO}

Quando, em 1938, Sezão participou do concurso Humberto de Campos, o autor assinava pelo pseudônimo de Viator, o que mostra a importância do motivo da viagem em Sagarana. O tema não só está presente nos nove contos e em quase toda a obra do autor, como também na temática sertaneja, seja na literária, seja na musical: são homens e mulheres que vagueiam de um lugar para outro, movidos por necessidades de sobrevivência ou de procura de melhores condições de vida, são boiadeiros que acompanham o gado para o ponto de embarque ou o movem de um local para outro, são proprietários que se deslocam para adquirir bens de consumo ou gado, são mascates que procuram vender uma grande variedade de produtos, são chefes políticos que andam pelas fazendas em busca de votos, e muitas outras situações resultantes da vida em regiões geograficamente isoladas, de baixa densidade populacional, de oferta reduzida de bens de consumo e de precários ou mesmo inexistentes sistemas de comunicação à distância.

O motivo viagem na obra de Guimarães Rosa, no entanto, não fica restrito a uma conotação utilitária; Benedito Nunes, em seu $O$ dorso do tigre, em um profundo estudo sobre o assunto, afirma que, por intermédio desse tema, Rosa liga-se à tradição dos chamados “Romances de espaço”, que vai do Don Quixote de Cervantes ao Ulisses de James Joyce (NUNES, 1969, p. 173). Ao referir-se a Sagarana, Nunes diz que os caminhos, que se aproximam, se cruzam e se afastam, percorridos pelas personagens dão ao leitor a idéia de que elas atuam por necessidade, sempre de uma forma préordenada por alguma razão que lhes é exterior:

As linhas do Fado, que no processo de viagem se desenrolam, mais flexíveis do que o fatum da tragédia grega, também podem cruzar-se devido à intervenção casual de terceiros. Exterioriza-se novamente, por intermédio desses agentes interpostos, o influxo daquela razão ou Providência muito próxima, pelo que tem de impessoal e objetiva, da pronoia dos estóicos. (NUNES, 1969, p. 176).

Estende essa conceituação sobre a viagem, considerando-a modalidade de travessia humana e fundindo-a com a existência do homem e com o sertão, espaço físico dentro do qual a trama se desenrola. Considera que não há, de um lado, o mundo, e, de outro, o homem que o atravessa, mas que, além de viajante, o homem é a viagem objeto e sujeito da travessia, em cujo processo o mundo se faz (NUNES, 1969, p. 179); portanto, “existir e viajar se confundem” (NUNES, 1969, p. 175). Nessa concepção da 
vida humana, o Destino, resultante de ações diversas que se conjugam, não tem a eficácia de uma força exterior e independente. Ele é

o resultado de forças opostas, conflitantes - as de Deus, mansas e constantes, as do Demo, bruscas e agressivas. Mas essas forças divididas só aparentemente são antagônicas. Viver é muito perigoso, porque não há clara delimitação entre elas. Apenas se pode saber que “Deus é definitivamente e o Demo o contrário dele”. ( NUNES, 1969, p. 178).

As observações de Benedito Nunes sobre a relação entre o motivo da viagem em Sagarana e o fatum da tragédia grega aplicam-se com muita propriedade a alguns contos, como Duelo e A hora e vez de Augusto Matraga. Mas, como vimos até aqui e ainda veremos quando analisarmos os demais contos, a viagem tem a função de apresentar um conjunto de desdobramentos que estão intimamente relacionados com as intenções morais, filosóficas e religiosas da obra - como também afirma Benedito Nunes -, além de assumir outras conotações. Ela pode primordialmente dar ao leitor as diretrizes para a interpretação do texto. É o que ocorre, por exemplo, na caminhada a cavalo que o Primo empreende da estação de trem à fazenda do tio Emílio, em Minha gente, durante a qual vão sendo narrados fatos que, literal, metafórica ou alegoricamente interpretados, estão intimamente relacionados com as idéias fundamentais presentes no conto; a viagem, neste caso, se torna uma espécie de prefácio e de confirmação das noções contidas no texto. Em outros casos, a viagem dá à personagem a possibilidade de descobrir-se, encontrar-se ou realizar-se, como ocorre em A hora e vez de Augusto Matraga quando Nhô Augusto se move de Muricy a Tombador e daí para Rala-Coco. Em A volta do marido pródigo, o protagonista, na viagem que realiza a uma região que lhe é estranha - a capital da República -, adquire consciência da profundidade das raízes que o ligam ao meio de onde se origina; conotação similar está presente nos contos narrados na primeira pessoa - Minha gente, São Marcos e Corpo fechado -, nos quais os narradores, homens da cidade, enfrentam a dificuldade de se adaptarem à mentalidade do sertanejo. Em O burrinho pedrês, a viagem do Major Saulo aos confins de Goiás tem a função de mostrar as ações do desbravador que chega aos limites geográficos exploráveis, que, no conto, têm significado positivo, porque geradoras de progresso econômico.

As noções de Benedito Nunes sobre o tema da viagem e sua estreita relação com as ações das personagens são valiosas para nossa de análise de Duelo. Nunes afirma que neste conto as linhas do destino se cruzam pela intervenção casual ou súbita de uma nova personagem. Essas noções são mostradas quando Turíbio Todo assassina 
acidentalmente o irmão de Cassiano Gomes; este, para vingar-se, persegue o assassino de seu irmão, que foge do vingador. Os dois contendores, nessa perseguição sem trégua, ora se aproximam, ora se afastam um do outro, porém jamais se encontram. A vingança só se efetuará depois da morte de Cassiano Gomes, pela intervenção de uma terceira personagem, o capiau Vinte-e-Um, a quem Cassiano socorrera com auxílio financeiro; o capiau, por gratidão, leva a cabo o desejo de seu benfeitor, matando Turíbio Todo, que, acreditando-se seguro com a morte de seu perseguidor, voltara tranqüilo para reinstalar-se no seu sítio, ao lado de Dona Silivana, sua mulher e pivô de toda a trama. A ilustração do alto da página 149 da 5 a . edição do livro mostra um círculo e, nele, inscrita uma grande mão aberta em cuja palma se vêem dois cavaleiros caminhando em direções opostas. O sentido da ilustração é claro: a mão do narrador e, em sentido mais amplo, as mãos do autor e de Deus, irão conduzir constantemente as ações de Turíbio e Cassiano e impedirá que se encontrem. Por causa dos vínculos que os dois homens

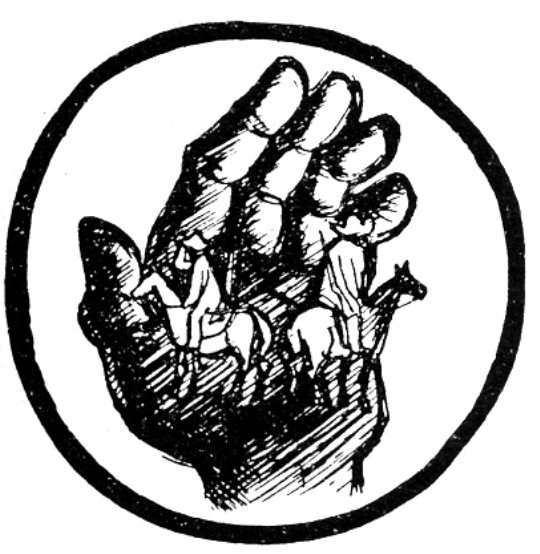
mantêm com as outras personagens do conto, o destino destas ficará também determinado.

Grande parte de Duelo se desenrola na paisagem do sertão, por onde os dois contendores se movimentam sem parar. O sertão de Guimarães Rosa tem sido objeto de grande número de análises, em virtude dos muitos discursos de Riobaldo sobre o motivo. A consideração de todos eles termina por propiciar e justificar muitas interpretações, algumas das quais conflitantes, que enriquecem o texto e possibilitam o melhor entendimento da obra do autor; para o escopo do nosso trabalho, utilizaremos as palavras do herói de Grande sertão: veredas, apropriada ao meio em que a obra se desenvolve: "sertão é onde manda quem é forte, com as astúcias.” (ROSA, 1956, p. 20), que parece coincidir com o pensamento de Hobbes: "Na guerra, a força e a fraude são as duas virtudes cardeais” (HOBBES, 1974, p. 81).

A violência e a traição que percorrem Duelo já são sinalizadas na mais violenta epígrafe de Sagaran :

E grita a piranha cor de palha, irritadíssima:

- Tenho dentes de navalha, e 


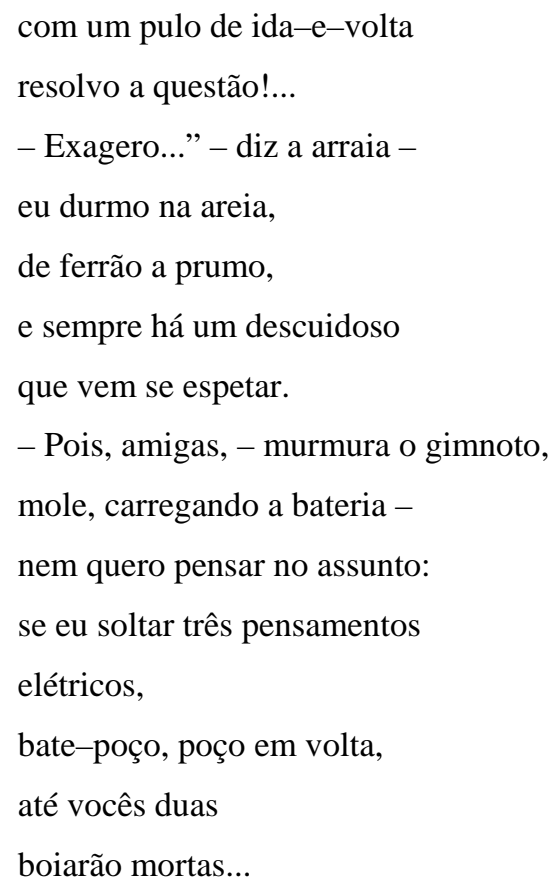

A piranha é o animal irritadiço e impulsivo, que utiliza a violência cega e a força bruta para a luta pela sobrevivência. Toma a iniciativa do assalto e investe com os dentes, que é a forma mais feroz e selvagem de agressão. Sua ação é rápida, definitiva, com dentes de navalha. A arraia, por seu turno, espera, dormindo e camuflada na areia, algum imprudente que se ofereça como presa involuntária; sua força é a paciência e a calma. Finalmente, o gimnoto, que quando sobe à superfície para respirar, aproveita a ocasião para recolher suas vítimas que bóiam na água, emprega uma arma mortal, a descarga elétrica. Os três animais reúnem, desse modo, três formas de agressão que, apesar de distintas, podem atuar mortalmente umas sobre as outras. Vigilância permanente é necessária para não ser atacado de maneira imprevista e não cair vítima da fúria da piranha, da mortal descarga elétrica do gimnoto ou da traição da presença camuflada da arraia. E assim, a sobrevivência dependerá da força e da astúcia no ataque e na defesa, o que sabiamente nos afirma o experiente Riobaldo, conhecedor prático da selvageria humana. Na epígrafe, a agressividade animal é metáfora da violência humana e, no conto, os homens descem a um nível de selvageria mais baixo que o dos próprios animais. A epígrafe também sintetiza a tônica da narrativa: quatro personagens Cassiano Gomes e Turíbio Todo, Silivana e o capiau Vinte-e-Um - se envolvem em complicado e perigoso jogo tático e estratégico que envolve traição, perseguição e fuga, paciências e impaciências, astuciosas formas de despiste e de engano com o fito de caçar e escapar de ser caçado. Ao relacionar intimamente a sobrevivência física com a 
incessante locomoção de Turíbio Todo e Cassiano Gomes, a viagem termina por converter-se - como nos diz Benedito Nunes - na travessia humana, e existir e viajar se confundem. E a viagem se torna metáfora da própria vida, pois continuar vivendo significa continuar viajando, e parar de viajar é defrontar-se com a traição e a morte.

A causa desencadeadora das ações dos homens são suas paixões e as regras sociais a que eles estão submetidos: Turíbio ama a mulher, Silivana, e, traído por ela, trata de matar-lhe o amante. De acordo com a regra moral vigente no meio em que o conto tem lugar, é justo que ele assim proceda, pelo menos assim nos é dito: "Mas, no começo desta estória, ele estava com a razão.” (p. 141). Podemos presumir que Turíbio está com a razão somente no começo da história porque não despreza ou não mata também a mulher adúltera, pois essa é a regra completa, como se deduz da chistosa afirmação do narrador:

Nem por sonhos pensou em exterminar a esposa (Dona Silivana tinha grandes olhos bonitos, de cabra tonta), porque era um cavalheiro, incapaz da covardia de maltratar uma senhora, e porque basta, de sobra, o sangue de uma criatura, para lavar, enxaguar e enxugar a honra mais exigente. (p. 144)

Seguir o preceito estabelecido de matar a mulher adúltera e seu amante é o que tenta fazer Matraga: “Nele, mal-e-mal, por debaixo da raiva, uma idéia resolveu por si: que antes de ir à Mombuca, para matar o Ovídio e a Dionóra, precisava de cair com o Major Consilva” (p. 334). Ou primo Ribeiro em Sarapalha: “- P’ra que, Primo Argemiro? Que é que adiantava?... Eu não podia ficar com ela mais... (...) E, ela, eu tinha obrigação de matar também, e sabia que a coragem p'ra isso havia de faltar...” (p. 129); ou ainda Silvino, de O burrinho pedrês, que pretende matar Badú, o homem que lhe roubara a namorada. Porém, do ponto de vista a partir da qual se elabora a narrativa de Duelo, Turíbio pode também ter deixado de ter razão pelo fato de tentar atingir Cassiano à traição, além de matar um inocente. Joãozinho Bem-Bem, em A hora e vez de Augusto Matraga, evoca a regra contra os argumentos do velho pai do assassino de um de seus homens a traição: “- Lhe atender não posso, e com o senhor não quero nada, velho. É a regra... Senão, até quem é mais que havia de querer obedecer a um homem que não vinga gente sua, morta de traição?... É a regra.”(p. 366).

Poupar a mulher adúltera, tentar matar pelas costas, assassinar um inocente e esconder-se de um rival são atitudes desprezíveis no meio em que o conto se desenrola. 
Por isso, na travessia do rio Paraopeba, Chico Barqueiro não esconde seu desdém por Turíbio:

“- Eu sei... Vai fugindo, se escondendo... Fico até com nojo de ver tanta falta de pouca vergonha emporcalhando a minha balsa!”.

E cuspiu n’ água, escarrando com estrondo.” (p. 155)

Cassiano Gomes, por seu turno, também atua segundo a regra em vigor: a morte do irmão à traição exige vingança impiedosa, como a que Joãozinho Bem-Bem tenta realizar contra o velho, na passagem acima aludida. O cumprimento da regra deixa Cassiano e Turíbio cegos para a razão: “e, se parassem e pensassem no começo da história, talvez cada um desse muito do seu dinheiro, a fim de escapar dessa engronga, mas coisa isso que não era crível nem possível mais.” (p. 148). Podemos avaliar o peso do código tácito do sertão se observarmos que, por problema cardíaco, Cassiano havia dado baixa da polícia (p. 150-51) e, por causa do extenuante esforço físico despendido na perseguição a Turíbio, tem a saúde gradualmente agravada e volta a beber. Desse modo, a tão almejada vingança, obstinadamente perseguida, de levar Turíbio à morte, faz que ele mesmo vá se aproximando da morte de maneira irreversível, até sucumbir no Mosquito. Essa obstinação suicida é bem descrita em Sezão, no diálogo entre Cassiano e o boticário; os dois últimos parágrafos da passagem abaixo foram mantidos em Sagarana (p. 160):

Foi ao boticário, e pediu franqueza. .

- Franqueza mesmo, mesmo, seu Cassiano?... O senhor... Bem, se isso incha de tarde e não incha nos olhos, mas só nas pernas, é mau sinal, porque em vez de ser dos rins deve ser do coração... Eu acho que nesse andar o senhor não dura muito... Isso não é brinquedo!... Agora, se o senhor não facilitar, ainda pode viver mais do que eu...

- Está direito!...

E pensou: vendo tudo o que tenho, apuro o dinheiro, vou no Paredão-do-Urucuia, dar a despedida p’ra a minha mãe... Depois, então, afundo por aí abaixo, e pego o Turíbio lá no São Paulo, ou onde for que ele estiver.

E despediu-se de todo o mundo, sabendo que nunca mais iria regressar. (ROSA, 1937, p. 126-7).

Pelo que se pode deduzir da narrativa de seus últimos momentos de vida, que transcrevemos abaixo, Cassiano aparentemente é um cristão. Na verdade, sua religiosidade pode ser sincera como também pode ser fruto de uma conveniente representação, cujo objetivo é alcançar a simpatia dos ingênuos habitantes do Mosquito. Se admitirmos que haja honestidade em sua fé cristã, concluiremos que ele sacrifica voluntariamente até mesmo sua alma na inflexível procura por vingança: solicita o 
socorro de um padre para assisti-lo no seu leito de morte, recebe os sacramentos e, logo depois, comete o pecado de instruir Vinte-e-Um sobre a forma de executar a ação sangrenta de matar Turíbio, ato para cuja realização estava fisicamente impossibilitado:

Veio o médico; veio o padre: Cassiano confessou-se, comungou, recebeu os santos-óleos, rezou, rezou.

Mandava o dinheiro para a mãe? Não. Mandou vir o Timpim, para nele rever a boa ação. Conversaram. Depois o moribundo disse:

- Esse dinheiro fica todo para você, meu compadre Vinte-e-Um...

Aí, tomou uma cara feliz, falou na mãe, apertou nos dedos a medalhinha de Nossa Senhora das Dores, morreu e foi para o Céu. (p. 165).

Mas, mesmo admitindo que a religiosidade de Cassiano seja sincera, pode simplesmente ser de pouca consistência, a ponto de não fazê-lo crer que o ato que está cometendo levará sua alma à perdição. Ou então o código de honra é mais palpável e concreto que um fugidio reino do outro mundo e o peso dos códigos de conduta do meio é muito maior que o dos valores religiosos - como se vê em toda a História, até em plena Idade Média, com todo o peso do catolicismo. Pela descrição feita por Vinte-eUm dos momentos finais de Cassiano, podemos imaginar com clareza o capiau recebendo as instruções para assassinar Turíbio: "E eu prometi, quando ele já estava de vela na mão...”(p. 171) ou “eu prometi ao meu compadre Cassiano, lá no Mosquito, na horinha mesma d'ele fechar os olhos...”(p. 171). Vinte-e-Um menciona Deus e Cristo ao mesmo tempo em que descumpre o quinto mandamento, realizando um ato que se assemelha ao de Cassiano.

A passagem da página 165, quando se afirma que Cassiano Gomes foi para o céu, tem-se uma mostra do humor que permeia todo o Duelo, que é o conto em que a linguagem se mantém no mais alto tom de graça e espírito de todo o Sagarana. Principiando pelas chistosas referências ao papo de Turíbio Todo, continuando na narrativa das artimanhas de Silivana, nas manobras de Cassiano na sua perseguição, na astuciosa fuga de Turíbio, a linguagem da narrativa só adquire caráter mais sério a partir da chegada do ex-militar ao Mosquito. A rigor, a leveza dessa linguagem está em desacordo com a própria trama narrada - a de um perigoso triângulo amoroso destinado a terminar em sangue -, e essa pode ter sido a forma encontrada para aliviar a tensão que envolve o leitor da obra, preso ao permanente ziguezague de duas personagens que nunca se encontram. Mas - e esta é a hipótese mais viável - pode também suceder que o humor serve para impedir a catarse e tudo se passa como se o objetivo do narrador fosse 
diferente do que o de fazer o leitor se emocionar com a história; as misérias, as paixões humanas e as regras de conduta a que as personagens estão implacavelmente subordinadas são vistas de um ponto mais elevado pelo narrador que, por compreender a transitoriedade da viagem do homem pela vida, parece levar pouco a sério aquelas fraquezas dos seres humanos. Em uma passagem, o narrador se expressa a partir de um ponto de vista amplo - o mesmo ocorrerá em Conversa de bois -, em contraposição à visão restrita dos homens e dos animais, fazendo um percurso vertical que desce gradualmente da beleza do topo das montanhas às rotas subterrâneas dos animais em luta pela sobrevivência e no qual o homem e sua inseparável violência ocupam posição intermediária:

...Altos são os montes da Transmantiqueira, belos os seus rios, calmos os seus vales; e boa é a sua gente... Mas, homens são os homens; e a paciência serve para vãos andares, em meados de maio ou no final de agosto. Garruchas há que sozinhas disparam. E é muito fácil arranjar-se uma cruz para as sepulturas de beira de estrada, porque a bananeira-do-campo tem os galhos horizontais, em ângulos retos com o tronco, simétricos, se continuando dos lados, e é só ir cortando todos, com exclusão de dois. E... quê? O tatupeba não desenterra os mortos? Claro que não. Quem esvazia as covas é o tatu-rabomole. O outro, para que iria ele precisar disso, se já vem do fundo do chão, em galerias sinuosas de bom subterrâneo? Come tudo lá mesmo, e vai arrastando ossadas para longe, enquanto prolonga seu caminho torto, de cuidoso sapador. (p. 143-4)

Já dissemos que em Sagarana as passagens com manifestações agressivas de animais e plantas comportam interpretações literais e metafóricas que se completam. Duelo, porém, constitui um caso à parte, porque aqui há permanente contraposição entre os homens e o restante da natureza: enquanto os primeiros transpiram e disseminam violência e traição e se debatem numa luta encarniçada e sem sentido, a natureza é pacata, tranqüila, plena de poesia, e a intromissão do homem como que a conspurca e macula. Desse modo, é como se os homens caíssem abaixo do nível dos animais. Observem-se os exemplos que daremos a seguir; no primeiro, é poeticamente mostrada a beleza da natureza que abriga os dois rivais:

E assim continuaram, traçando por todos os lados linhas apressadas, num raio de dez léguas, na mesopotâmia que vai do vale do Rio das Velhas - lento, vago, mudável, saudoso, sempre nascente, ora estreito, ora largo, de água vermelha, com bancos de areia, com ilhas frondosas de mato, rio quase humano, - até ao Paraopeba - amplo, harmônico, impassível, seivoso, sem barrancas, sem rebordos, com praias luminosas de malacacheta e águas profundas que nunca dão vau. (p. 148). 
Cassiano sai de uma toca, armado como um animal perigoso e traiçoeiro, ao mesmo tempo em que grilos, corujas e um cachorro vivem em paz: “Quando escureceu de todo, ele saiu da toca, se esgueirando, de arma lesta. Havia toadas de grilos, houve risadas de corujas, e, dos fundos da noite, muito fresca, um cachorro latiu.” (p. 152). No seguinte, a narrativa da serenidade transmitida pelos animais, pelas plantas e pelos rios é abruptamente interrompida pela presença do homem forte, armado de foice, que emite sons de animal feroz:

Mutuns cantaram, certos, às horas em que cantam os galos. No mais, distante, o mato dormia, num quiriri sem alarmas. O rio era um longo tom, lamentoso. Caía, das estrelas, um frio de se sentar em costas de homem. E crescia, com as horas, o cheiro das folhagens molhadas. Depois, com os passarinhos, chegou a madrugada. A barra do dia vinha quebrando. E um sujeito, alto e espadaúdo, apareceu, em pé, diante do bivaque. Vinha armado de foice, e roncou: (p. 152-53).

Na passagem abaixo, Turíbio e Vinte-e-Um estão caminhando juntos. A narrativa é tensa, pois o leitor, mesmo ao ler o conto pela primeira vez, supõe que algo de extraordinário está para suceder. A descrição da beleza da natureza que circunda os dois homens é claramente contrastante com a tensão do momento narrado. A narrativa do velho que se equilibra na pinguela para não cair no córrego é metáfora do risco da situação que envolve os dois homens. Turíbio é atraído pela natureza - como o é pelo capiau -, cego ao trágico destino que o aguarda:

Deram no vau de um córrego. Um velho, de saco nas costas, vinha de lá, passando a pinguela; quis cumprimentar e quase caiu, custando-lhe reajustar o equilíbrio. Na lama lisa da margem, borboletas amarelas pousavam, imóveis, como pétalas num chão de festa.

Os cavalos, metidos até meia canela na correnteza, dobravam o pescoço em ângulo obtuso, para beber. Cardumes de piabinhas, chofrando corridas ou oscilando no mesmo lugar com palpitações de aletas, rabeavam na transparência da água, que os animais sorviam num chorro copioso.

$\mathrm{O}$ ar era fresco. Do morro, vinha um cheiro bom de musgo, de barba-de-pau, de verdura velha. E a sela estava tão macia, e tão embalador o marulho, que Turíbio estirou uma perna no estribo e ficou olhando, com afeto, para um cavalinho-de-judeu, que pairava faiscante e acabou pousando no látego do cabresto. (p. 169)

Na travessia do rio Paraopeba por Turíbio e Chico Barqueiro, este faz uma longa descrição do movimento instintivo das aves em migração. De modo geral, a descrição é figurativa dos movimentos efetuados pelos dois inimigos - como em "Conheço esse gadinho de asa! Eles vivem p’ra lá e p’ra cá, aciganados, nunca que param de mudar...” (p. 156) -, mas mantém o contraste entre as ações brutais das personagens e a beleza da 
natureza. Desta faz parte a luta pela sobrevivência, como em “O carapinhé costuma passar também, mas só quando vem voando atrás de passarinho pequeno, querendo pegar...” (p. 156).

Além de ser uma metáfora do movimento dos dois contendores, efetuado ao mesmo tempo por necessidade e com liberdade, o parágrafo abaixo também trata de outro tema presente em Sagarana, o do embate entre duas tendências, a de se livrar e a de retornar ao estado de desordem e selvageria:

... Às vezes, dá dó, quando chegam, no tempo da seca, uns patinhos cansados, que devem de ter vindo de longe demais... Assim que eles, por erro, acham que isto aqui é o São Francisco, que tem lagoas nas beiras... Pensam p’ra pousar nas canas de taquariubá... Gente vê que eles estão não agüentando de ir, mas que não é capaz de terem sossego: ficam arando de asas, parece que tem alguém com ordem, chamando, chupando os pobres, de de longe, sem folgar... P’ra mim, muitos desses hão de ir caindo mortos, por aí... Não crê que tudo é o regrado esquisito, amigo? (p. 156-7)

Esse aspecto pode ser mais claramente observado em Sezão, no qual a tendência ao retrocesso puxa os pássaros de volta para as matas de Goiás - lá mesmo, para onde o negrinho de $O$ burrinho pedrês quer voltar:

Eu acho que eles, por engano, pensam que isso aqui é o São Francisco e param p’ra pousar nas canas de taquariubá... A gente vê que eles estão não agüentando de ir mais p'ra diante, mas é capaz deles terem sossego: ficam pulando daqui p’ali, dando asas, parecendo que tem alguém dando ordem, chamando, chupando eles lá de longe, das matasvirgens, dos Goiás...P’ra mim, muitos desses hão de ir caindo mortos, por aí... Não acha que tudo isso é esquisito, amigo? (ROSA, J. G., 1937, p. 123-4)

A oposição estabelecida entre o caráter do homem e as manifestações da natureza, que vimos nas passagens acima, é particularizada na estada de Cassiano no Mosquito. O lugar é descrito como de natureza amigável, bucólico, inspira paz e tranqüilidade, mas o narrador, falando por Cassiano, nos diz que é local onde gente não gostaria de ficar:

Mas, no caminho, foi piorando, e teve de fazer alto no Mosquito - povoado perdido num cafundó de entremorro, longe de toda a parte -, onde três dúzias de casebres enchiam a grota amável, que cheirava a grão-de-galo, murici e gabiroba, com vacas lambendo as paredes das casas, com casuarinas para fazerem música com o vento, e grandes jatobás diante das portas, dando sombra. Um lugar, em suma, onde a gente não tinha vontade de parar, só de medo de ter de ficar para sempre vivendo ali.(p. 160-1).

A paisagem era triste, e as cigarras tristíssimas, à tarde. Passavam uns porcos com as cabeças metidas em forquilhas para não poderem varejar as cercas das roças. Passavam 
galinhas, cloqueando, puxando ninhadas para debaixo do marmelinho. E almas-de-gato, voando para os ramos escarlates do mulungu.(p. 161).

A população do Mosquito homenageia, submissa e conformada, o transmissor das moléstias tropicais que a assola; o autor alude neste conto, mais uma vez, à questão da saúde pública no Brasil, sobre a qual já falamos em Sarapalha, em duas passagens mais: a primeira, referindo-se à origem do papo de Turíbio; a segunda, ao homem encontrado por Cassiano em suas andanças, um vira-mundo que busca, como os habitantes do vau da Sarapalha, a cura da doença por meio da reza, fazendo, para sarar, um esforço físico que tende a agravar a doença e parece figurar a aproximação da morte de Cassiano, em sua obstinação de levar a morte a Turíbio: “Quando Cassiano dobrava a serra Sela do Ginete, transmontando para o Cuba, se encontrou com um vira-mundo pedidor-de-esmola, com pernas enormes de elefantíase, carregando, por promessa, a pesada imagem, já inidentificável, de um santo.” (p. 148). Mas, a despeito de abandonado pelo Estado, que o condena ao atraso e à doença, o Mosquito abriga gente simples, pacífica, hospitaleira; e ali Cassiano procura e não encontra valentões para executar, por dinheiro, sua vingança.

Mosquito guarda notável analogia com Tombador, onde o protagonista de $A$ hora e vez de Augusto Matraga cumpre a sua penitência, e essa analogia sugere buscar semelhanças e diferenças entre Duelo e aquele conto. O que se observa, sob esse aspecto, é que o comportamento de Cassiano é totalmente diverso do de Matraga. Este se arrepende de seu passado de pecados e segue um caminho de busca do Céu, inspirado pela frase de um padre que o assiste: "Cada um tem a sua hora e a sua vez: você há de ter a sua.” (p. 339). Cassiano também chama um padre na hora da morte, mas escondelhe o propósito que já tinha em mente durante a confissão. Como escrevemos acima, sua religiosidade é duvidosa, e é bem possível que ele simplesmente represente o papel de esmoler, fervoroso cristão, benfeitor desprendido, humano e sofredor, que distribui dinheiro aos habitantes do local para comprometê-los com a gratidão. Talvez algum sentimento de humanidade exista realmente nesse homem, ou pode existir em certo momento para desaparecer em outros; mas o leitor sempre desconfia da personagem e se sente convidado a suspender seu juízo, pois sabe que está lidando simultaneamente com uma personagem simulada e com um narrador irônico:

E, no jirau, meio sentado, meio deitado, recostando-se numa pilha - de molambos, travesseiros e até um selim velho - que mulheres caridosas lhe arranjavam, arfando com esforço e tomando posições para poder sorver algum ar, se esqueceu das armas de fogo e esperou a hora de morrer. A calma e a tristeza do povoado eram imutáveis, com cantigas de 
rolas fogo-apagou e de gaturamos, e os mugidos soturnos dos bois. E a placidez do ambiente lhe ia adoçando a alma, enquanto que a cara ficava cada vez mais inchada, em volta dos lábios laivos azulados, e a doença lhe esgarçava o coração.

Pegou a pedir às velhas que viessem rezar à beira da enxerga. Queria que os meninos, miúdos meninos, brincassem ali perto; e dava-lhes dinheiro. E ficava calado, recontando os caibros, negros de picumã, e espiando a mexida das aranhas, que jogavam fios-a-prumo para subir e descer. E, pela primeira vez nesses meses, se lembrou do irmão assassinado, realizando ser por causa da morte do mesmo que ele andara em busca de Turíbio Todo. E também pensou no Céu, coisa que nunca tivera tempo de fazer até então. (p. 164)

Nesta passagem fica claro que Cassiano, em seu projeto, é movido pela regra da vingança, e não propriamente por afeto ao irmão, pois somente já próximo da morte é que se recordará dele. O fato faz vir à mente a noção de René Girard, de que o ser humano busca, e sempre encontra, razões para praticar um ato violento: “A própria violência vai deixá-las de lado (as razões), assim que o objeto inicialmente visado sair de seu alcance e continuar a provocá-la.” (GIRARD, 1998, p. 245).

A história fica rigidamente determinada pelo narrador, que é literalmente dono dos destinos das personagens; ele penetra fundo no pensamento e ações dos componentes do triângulo amoroso, passando de um a outro em um vaivém que guarda estreita relação formal com o deslocamento físico dos dois desafetos e com a variedade das artimanhas de Silivana. Mas, ao utilizar, ao mesmo tempo, a ironia e o humor, o narrador acaba por deixar o leitor, em certos momentos, sem referência para avaliar a situação descrita; quando ele nos diz que “Aí, tomou uma cara feliz, falou na mãe, apertou nos dedos a medalhinha de Nossa Senhora das Dores, morreu e foi para o Céu.” (p. 165), sabemos que o “morreu e foi para o céu” é um chiste de um narrador onisciente, mas ficamos sem saber o quanto do restante da frase é verdadeiro ou falso, seja de parte da personagem, que estaria simulando, seja de parte do narrador, que estaria ironizando; a passagem antes transcrita, a do choro de Cassiano na presença de uma criança (p. 163), é outro dos muitos exemplos que poderiam ser mencionados. Essa dificuldade que o leitor sente de captar o caráter que o narrador quer imprimir às personagens é figura da dificuldade que as próprias personagens têm de entender as intenções umas das outras; portanto, o narrador faz com o leitor aquilo que as personagens fazem entre si quando empregam os mesmos artifícios de despistes, mentiras e fingimentos. Na passagem abaixo temos razões para acreditar na franqueza de Cassiano, porém na frase "porque chorar sério faz bem”, fica subentendido que um 
choro pode ser fingido, não estando excluído aí, obviamente, o choro da própria personagem:

E o menino, que era engraçadinho e esperto, abriu os olhos para Cassiano, que, ante tanta fragilidade, se enterneceu:

- Será que nem minha mãe eu não vejo, em-antes de eu morrer?!... - gaguejou, soluçando.

Pediu que o levassem para a cama; mas já era outro homem, porque chorar sério faz bem. (p. 163)

Quando, já no início do conto, o narrador diz que Turíbio “chorava sem fazer caretas” (p. 141), talvez esteja sugerindo que o leitor deve atentar para o choro dessa e de outras personagens do conto. Turíbio chora também no final: "E levantou a mão à testa, se benzendo, com voz gritada, em que o choro já começava a tremer.” (p. 171); Vinte- e- Um “entrou- lhe também pelo quarto, de olhos vermelhos e nariz a escorrer, choramingante” (p. 164). Das quatro personagens mais importantes, a perigosa Silivana é a mais insensível, porque é única que não chora, contrariando a regra geral, segundo a qual mulheres choram muito mais do que homens. E em Cassiano, quando perseguindo Turíbio, o choro surge com o ódio, o sentimento condutor de seus atos: "chegando ao São Sebastião, chorou de ódio” (p. 148).

É constante a mudança de ponto de vista com respeito a um mesmo objeto, que ora pode ser observado a partir da personagem, ora do narrador. Isso ocorre em muitas passagens, das quais mencionaremos apenas duas: numa, em que o objeto é a montaria de Vinte-e-Um, tem-se o ponto de vista de Turíbio, que, em suas observações, diz não saber se é égua ou cavalo, afirmando que "Era um cavalinho ou égua” (p.166); a seguir, o ponto de vista é do próprio narrador que, observador muito mais minucioso e melhor conhecedor do animal do que o próprio seleiro profissional, diz: "O cavalinho pampa era mesmo um cavalo” (p. 167). Um outro exemplo é o da passagem já referida, na qual o ponto de vista narrado é o do povo de Mosquito, para quem Cassiano "morreu e foi para o Céu.”(p. 165). Nos dois casos, a onisciência irrestrita do narrador serve de instrumento para a criação de um distanciamento irônico do leitor: não há segunda intenção, fraqueza ou mazela das personagens que o narrador não consiga desvendar para o leitor, ironizando ou não.

A ação do destino condutor dos contendores pode ser observada em algumas passagens da obra nas quais a hierofania do sol atua como guia das personagens: de Turíbio, quando “o papudo também descambara acompanhando o caminho do sol.”(p. 148); de Vinte-e-Um para as mãos Cassiano, na qual o sol é observador das artimanhas 
do soldado: "E, pois, foi um dia, quando ele estava pior e tinha mandado abrir a janela para que entrasse um sol fiscal, muito ardente, entrou-lhe também pelo quarto (...) o Timpim.”(p. 164). Em outra passagem ocorre a disputa do sol com outra hierofania, a da água: “A alegria da liberdade larga nem o deixava sentir as bátegas que de vez em quando desciam, porque estava um dia incerto, de casamento de raposa ou de viúva, com uma chuvinha diáfana, oblíqua e apressada, correndo aqui e ali para disputar com o sol.” (p. 166). Essa luta entre sol e chuva é a metáfora da disputa entre Turíbio e Cassiano, que ainda se mantém viva na personagem de Vinte-e-Um.

Ao sentir-se alegre e seguro com a morte de seu rival e supor que os efeitos de sua disputa com Cassiano haviam terminado, Turíbio está ignorando o destino que o aguarda. Esse fato transparece na passagem na qual um sagüi, que a tudo assiste fazendo momices e brincando de esconde-esconde, diverte-se às custas de Turíbio - e quiçá também de todas as outras personagens do conto e do próprio leitor. Como a raposa da epígrafe de Sagarana, o animalzinho transforma-se no alter ego do narrador, que, sempre sustentando o humor que lhe caracteriza a linguagem, metaforiza o vaivém dos movimentos, as atitudes e os sentimentos das personagens. Uma ilustração do sagüi fazendo estrepolias em um tronco de árvore ocupa praticamente de alto a baixo a página 176 da 5 a . edição:

Nos galhos mais altos do landi, um saguim, mal penteado e careteiro, fazia gatimanhas, chiando e dando pinotes. Os cavaleiros estacaram. Turíbio Todo tirou o revólver e apontou. Mas o macaquinho se escondia por detrás do pau, avançando, de vez em quando, só a carinha, para espiar. E Turíbio se enterneceu, e tornou a pôr a arma na cintura.

Enquanto isso, o mico espiralava tronco abaixo e pulava para o vinhático, e do vinhático, para o sete-casacas, e do sete-casacas para o jequitibá; desceu na corda quinada do cipó-cruz, subiu pelo rastilho de flores solares do unha-de-gato, galgou as alturas de um angelim;

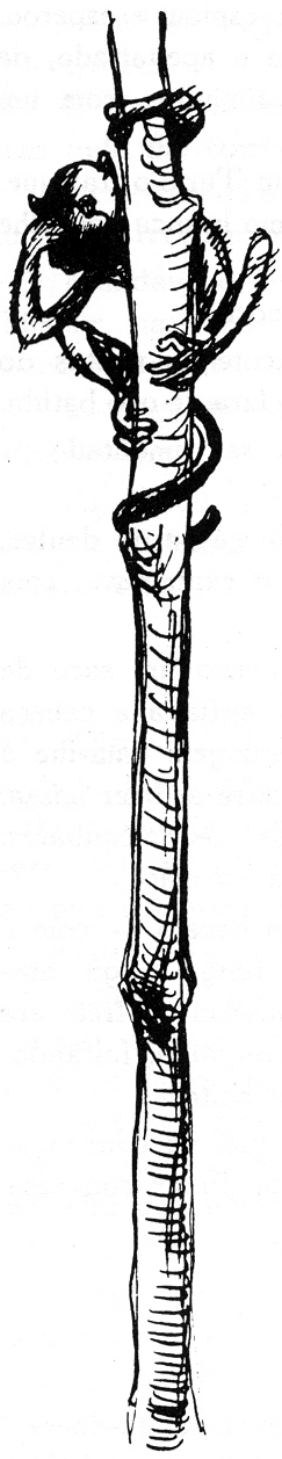
sumiu-se nas grimpas; e, dali, vaiou. (p. 168).

Acima comparamos Cassiano com Matraga e agora podemos fazer a comparação de Silivana com Dionóra. Dionóra toma uma decisão meditada e corajosa e 
se afasta de um mau marido em todos os aspectos, para viver o amor apaixonado de Ovídio Moura, mesmo sabendo do alto risco de essa atitude provocar violenta reação de Nhô Augusto. Seu caráter é marcado pela coragem e firmeza de propósitos. Silivana, ao contrário entra ardilosamente no infernal jogo dos dois homens, como parceira do amante, pelo menos até a morte deste. Após a morte de Cassiano, ela chama o marido de volta de Guaxupé: “Turíbio Todo soube da boa notícia, por uma carta da mulher, que, agora carinhosa, o invocava para o lar.”( p. 165). E aqui o leitor é acossado por uma pergunta sobre o que realmente se passou entre a morte de Cassiano e o retorno de Turíbio Todo, a de como Vinte-e-Um soube exatamente o dia e a hora da chegada de Turíbio a Vista Alegre. Uma hipótese razoável é que Vinte-e-Um tenha informado Silivana da morte de Cassiano, a pedido deste, e que tenha arquitetado com a mulher o plano de atrair Turíbio para matá-lo, realizando desse modo a última vontade de Cassiano. A descrição de Silivana pode ajudar-nos a entendê-la, pelo menos em parte. Ela "tinha grandes olhos bonitos, de cabra tonta” (p. 144). Quatro vezes são descritos os olhos - e só os olhos - como característica da personagem. Isto indica que os olhos da mulher devem ter algum significado importante no conto que, infelizmente, não conseguimos alcançar de maneira totalmente satisfatória. No entanto, podemos arriscar um sentido para eles: Câmara Cascudo registra, no verbete “cabra”, que "o animal é tido como simpático ao diabo. Uma das orações demoníacas mais fortes é a famosa Oração da cabra preta (CASCUDO, 1969, p. 327). No verbete "olhos”, o mesmo autor menciona a expressão “olhos de cabra morta: tristes, lânguidos, sem expressão.” O nome da personagem, corruptela de Silvana, vem do latim "Silvanus", habitante da floresta; entre os antigos romanos, Silvano era equivalente ao Pan da mitologia grega, entidade com orelhas e pés de bode (OLIVER, 2005). Pan é entidade demoníaca associada ao bode nos rituais de feitiçaria. (RONCARI, 2004, p. 135). Seja qual for o significado que possamos atribuir a essa característica física da personagem, ele pode ser resumido com a afirmação de estamos diante de uma mulher astuta e perigosa.

Das quatro personagens principais, Vinte-e-Um é a única realmente íntegra e honesta. Sem se dar conta de que foi habilmente corrompido por Cassiano, executa honradamente um ato que lhe é custoso, pois "Muito abatido, lúgubre, dava o ar de quem estivesse carregando o peso do mundo.” (p. 170); por escrúpulo e dignidade não responde ao gesto amistoso de Turíbio, que lhe oferece cigarros (p. 167), recusa o dinheiro (de que tanto precisa) de Turíbio para que lhe poupe a vida e cuida de salvar a alma do homem que irá matar: “- Pois então reza, seu Turíbio, que eu não quero a sua 
perdição!” (p. 171); “- Não grita, seu Turíbio, que não adianta... Peço perdão a Deus e ao senhor, mas não tem outro jeito” (p. 171). Em Sezão, o desgosto de Vinte-e-Um por matar Turíbio é ainda mais explícito: “- Não tem jeito, não tem jeito, seu Turíbio... Abaixo de Deus, foi ele quem salvou a vida do meu menino... E eu prometi, quando ele já estava de vela na mão...Não pense o senhor que é por gosto que eu vou fazer isso, não... É uma tristeza! Mas jeito não tem... Tem remédio nenhum...” (ROSA, J. G., 1937, p. 137). Suas ações são guiadas pelo código do meio, ao qual ele se subordina submisso, reprimindo, desse modo, uma agressividade que não passa despercebida a Cassiano:

- E por que é que você, que tem essa testa cabeluda de homem bravo, e essas sobrancelhas fechadas, juntando uma com a outra por cima do nariz, por que é que você ficou quieto e não bateu nele também? ...

- Não vê que a minha mãe sempre falava p'ra eu não levantar a mão p’ra irmão meu mais velho... E, como eles todos são de mais idade, por isso todos gostam de dar em mim. (p. 163).

Como acontece com várias personagens de Guimarães Rosa - Matraga é o exemplo em Sagarana -, Vinte-e-Um tem três nomes: "O senhor vai se rir de mim... Mas, se me chamar por meu nome direito, de Antônio, ninguém não fica sabendo quem é... Timpim é apelido que eu não gosto... Antes mesmo me chamando de Vinte-e-Um.” (p. 162). Antônio é, portanto, seu nome de batismo, desconhecido dos habitantes de Mosquito; Timpim, o tratamento rejeitado pela personagem, é empregado pelo narrador, possivelmente por indicar seu corpo franzino; e Vinte-e-Um é empregado por Cassiano. No final do conto, os dois últimos se agrupam: "Então, o caguinxo Timpim Vinte-e-Um fez também o em-nome-do-padre” (p. 172). O nome da personagem é uma referência ao jogo de cartas vinte-e-um, e, em dado momento o narrador fala do baralho como metáfora do jogo de perde e ganha que se desenrola entre os dois contendores “- Tem tempo... - disse. E continuou a batida, confiado tão só na inspiração do momento, porquanto o baralho fora rebaralhado e agora tinham ambos outros naipes a jogar.”(p. 146); Timpim, portanto, ao chamar-se também Vinte-e-Um, passa a fazer parte do jogo de fugas e perseguições que se desenvolve no conto. Cassiano impede a participação de Izé, irmão de Timpim, nesse jogo: “- Sai p’ra lá, diabo! Tu é valente demais. Tu é ferrabraz... Sai daqui, que o baralho ainda não bateu na tua porta.” (p. 162).

Em Sagarana há uma galeria de personagens violentas; mas todas elas ou têm motivos atenuantes para seus atos ou, na contingência de cometer algum ato violento, 
sentem alguma forma de temor perante a morte próxima e procuram preservar a vida ou a alma: Silvino, de $O$ burrinho pedrês, e Alexandre, de Minha gente, têm razões imediatas para matar seus rivais, pois estão sob o impacto da traição das mulheres que amam, ao mesmo tempo em que a regra social valida suas ações. Tiãozinho, de Conversa de Bois, mata Agenor Soronho movido pelo ciúme que tem da mãe, pelo amor que tem ao pai e pela brutalidade do carreiro. O valentão Targino, de Corpo fechado, hesita e teme por sua vida ao ver a resolução do pusilânime Manuel Fulô, no momento do duelo entre ambos. O violento Nhô Augusto, de A hora e vez de Augusto Matraga, vê a morte próxima e, arrependido, passa a viver rigorosa devoção religiosa. Quando comparado a esses homens, Cassiano representa o extremo da violência, aquela que o leva o indivíduo a não hesitar em prejudicar a própria mãe, comprando o capiau, e em perder a vida e a alma, se realmente for cristão, para levar à morte um desafeto; e mais: por causa do assassínio de um irmão de quem mal se lembra. A violência em Cassiano é um fim em si, uma razão de vida. Desse ponto de vista, ele é a mais violenta personagem de Sagarana.

Por outro lado, dos protagonistas de Sagarana, ele é o único da polícia - que em alguns contos é representada por personagens secundárias e inoperantes e em outros não é sequer mencionada. Este fato leva a perguntar por que Guimarães Rosa optaria por dar a uma personagem proeminente, dona de um caráter tão violento, a profissão de policial. A resposta pode estar no ponto de vista do autor sobre a incapacidade das instituições brasileiras na Primeira República em manter o estado de ordem social sob o império da lei. Para impor ordem, ainda que precariamente, criam-se em Sagarana soluções variadas e locais, por meio das quais sempre se acaba por combater a violência com a própria violência. Esta maneira de combater o estado de desordem tornaria, em essência, um policial tão violento quanto um delinqüente e terminaria por reconduzir a sociedade para um estado de desordem, criando-se, desse modo, um perverso círculo vicioso. E dessa forma, Cassiano, homem que exerce uma forma de autoridade destinada ao estabelecimento da ordem, possui traços de caráter que instalam a desordem. Constatamos em Cassiano o caso prático da noção de Frederico Pernambucano de Mello "No sertão, do criminoso à autoridade e, desta, àquele, a distância é nenhuma.” (MELLO, 2005, p. 185). Para punir o assassino de seu irmão ele não recorre às autoridades oficialmente estabelecidas - de cuja existência só tomamos conhecimento por meio de sua própria profissão -, mas faz justiça com as próprias mãos, ou seja, vê omisso o Estado do qual era representante. É a ausência de um Estado 
mantenedor da justiça que estimula Turíbio a um crime de sangue que ele sabe que ficará impune como tantos outros, “Agora tinha de cair no mundo e passar algum tempo longe, e tudo estaria muito bem, conseqüente e certo, limpamente realizado, igualzinho a outros casos locais.” (p. 144), ou que permite a alguém viver abertamente às custas de roubo: “topou com um ladrão de cavalos, que subia com a última tropilha, porque já tinha ganho muito dinheiro e voltava para sua terra para tornar a ser honesto.” (p. 148).

Face às considerações que fizemos acima, é possível tratar de outro aspecto que também pode ser vislumbrado no conto. Trata-se da discussão da relação de causa e efeito. A intenção de levantar o assunto é manifestada claramente na passagem abaixo:

E, ainda assim, saibamos todos, os capiaus gostam muito de relações de efeito e causa, leviana e dogmaticamente inferidas: Manuel Timborna, por exemplo, há três ou quatro anos vive discutindo com um canoeiro do Rio das Velhas, que afirma que o jacarédo-papo-amarelo tem o pescoço cor de enxofre por ser mais bravo do que os jacarés outros, ao que contrapõe Timborna que ele só é mais feroz porque tem a base do queixo pintada de limão maduro e açafrão. E é até um trabalho enorme, para a gente sensata, poder dar razão aos dois, quando estão juntos. (p. 142)

Nessa passagem dois homens debatem se o papo do jacaré-do-papo-amarelo é causa ou efeito de sua ferocidade. Poderíamos interpretá-la como indagação sobre os inúmeros defeitos de caráter de Turíbio, ou seja, se seriam eles a causa ou o efeito de seu papo. Essa questão, de tom humorístico e irrelevante na aparência, tem, no entanto, desdobramentos na interpretação do conto. O fato que desencadeia toda a trama, o adultério de Silivana, é a origem de uma seqüência de causas e efeitos que se fechará com o assassínio de Turíbio por Vinte-e-Um; no entanto, como acontece em qualquer texto, só se pode falar do começo e do fim de uma seqüência de eventos, se seus limites no tempo e no espaço forem arbitrariamente estipulados, espécie de marcos inicial e final da seqüência causal. No conto, os limites são os da duração dos fatos narrados e é por esse motivo que o narrador, por duas vezes, estabelece o ponto de partida dessa seqüência: “Mas, no começo desta estória, ele estava com a razão”(p. 141); “de qualquer maneira, nesta história, pelo menos no começo - e o começo é tudo - Turíbio Todo estava com a razão.”(p. 142). Por outro lado, são igualmente demarcados os limites espaciais no conto; de um lado, Guaxupé, em Minas, e de outro, Piedade do Bugre, duas vezes referida no texto: "para diante não havia terras aonde um cristão pensasse ir” (p. 145), e "bastara-lhe um dia de repouso, para compreender que estava num fundo-de-saco, pois que aquele lugarejo era a boca do sertão.” (p. 146). 
Cassiano é causa dos passos de Turíbio e vice-versa. Esses movimentos dos dois contendores são sempre guiados pela análise meticulosa das possíveis atitudes que o rival possa tomar, como no exemplo abaixo, um dos muitos casos que poderiam ser mencionados:

Cassiano pensou, fumou, imaginou, trotou, cismou, e, já a duas léguas do arraial, na grande estrada do norte, os seus cálculos acharam conclusão: Turíbio Todo tinha uns parentes na Piedade do Bagre, ou ali por menos longe... Para lá batera, direitinho, ainda assustado por conta do malfeito. Não podia ter tomado outro rumo, e, de seguro, dando o mais que pudesse, teria vindo a galope. Quando ele chegasse na Piedade - para diante não havia terras aonde um cristão pensasse ir, - descansado, junto de gente sua, tornaria a ter raiva e tratava de voltar nos passos. (p. 145)

Para desenvolver a interpretação sob o enfoque de causa e efeito, vamos nos deter nas primeiras cinco vezes das sete nas quais é empregado o vocábulo "razão” pelo narrador, sempre em conotações similares de "pensar e julgar bem, estar de acordo com o que se considera verdadeiro” (AULETE); duas, referentes a Turíbio, já foram citadas. Referindo-se à polêmica relativa ao jacaré-do-papo-amarelo: "E é até um trabalho enorme, para a gente sensata, poder dar razão aos dois, quando estão juntos.” (p. 142). Afirmação de Cassiano em sua perseguição a Turíbio: “- Ele vai como veado acochado, mas volta como cangussu... No meio do caminho a gente topa, e quem puder mais é que vai ter razão...” (p. 145). Opinião do narrador sobre os eventuais riscos que corre um perseguidor: "Mas Cassiano fiava muito pouco nessa correria, porque a qualquer momento a caça podia voltar-se, enraivada; e vem disso que às vezes dá lucro ser caça, e quem disser o contrário não está com a razão.” (p. 146-47) ${ }^{20}$

Podemos admitir que a presença do termo por cinco vezes nas seis primeiras páginas do conto tenha sido intencional. A referente ao jacaré-do-papo-amarelo teve por objetivo levantar a questão da relação de causa e efeito na obra, como acima dissemos. Parece-nos que a última passagem teve por objetivo mencionar o termo “razão" mais uma vez e, ao mesmo tempo, mostrar um narrador arbitrário que não admite contestação. As palavras de Cassiano têm especial interesse, uma vez que trazem embutida a noção de que, na batalha entre os dois contendores, a razão estará com

\footnotetext{
${ }^{20}$ Em Sezão, esta passagem é carregada de humor:

Fugindo, Turíbio- Todo levava aparentemete a pior. Mas Cassiano fiava muito pouco nessa correria, porque ainda não fora aprovado um código esportivo para duelos desse gênero e, a qualquer momento a caça podia voltar- se contra o caçador, e vem disso que às vezes dá lucro ser caça, e quem disser o contrário não está com a razão. (ROSA, J. G., 1937, p. 113)
} 
aquele que for mais forte, astuto e habilidoso no manuseio das armas; esta é, obviamente, a lei da selva, mas a afirmação é de Cassiano, justamente aquele que deveria ser modelo de aplicação da lei do Estado civilizado. Dessa forma, por um outro caminho, voltamos à mesma situação a que já nos referimos.

As duas referências a Turíbio são do narrador; como vimos acima, elas suscitam a dúvida de quando e por que Turíbio deixa de ter razão, porém, o que realmente importa é que o Estado não está presente para julgá-lo, a fim de estabelecer a justiça, analisando todos os atenuantes e agravantes que o levaram ao crime. Com isso, Cassiano, movido por uma agressividade que não encontra obstáculo para se manifestar, assume o papel do Estado, julgando e punindo o rival à luz de seus próprios critérios embasados nas regras de conduta local. Em um Estado presente e civilizado, a solução do debate permanente sobre onde e com quem está a razão é função explícita da Justiça.

Várias personagens de Sagarana encontram a si mesmas e adquirem ou recuperam sua identidade durante a narrativa. Falamos sobre primo Argemiro, de Sarapalha, como um desses casos.

Vinte-e-Um, casado e com três filhos, pensa de si mesmo que nada vale "Deus há de lhe dar o pago, seu Cassiano Gomes! Eu sim que não posso, por causa que não tenho préstimo nenhum...” (p. 165) - e é espancado pelo irmão Izé, mas sua condição de caçula impede que mostre qualquer reação: “- Não vê que a minha mãe sempre falava p'ra eu não levantar a mão p'ra irmão meu mais velho... E, como eles todos são de mais idade, por isso todos gostam de dar em mim.” (p. 163). Mas, ele tem a testa cabeluda como o capiau apaixonado pela Sariema de A hora e vez de Augusto Matraga e, portanto, pertence a "uma raça de homem capaz de guardar o passado em casa, em lugar fresco perto do pote, e ir buscar da rua outras raivas pequenas, tudo para ajuntar à massa mãe do ódio grande, até chegar o dia de tirar vingança.” (p.334); com a chegada de Cassiano - que nele vê essa sua predisposição latente de matar -, encontra sua verdadeira identidade, que estava moral e socialmente reprimida: o sentimento de gratidão ao benfeitor pelo favor recebido é a autorização para fruição sem culpa do impulso que o leva a consumar o ato homicida, e o assassínio se torna, agora, moralmente justificável. Turíbio, ao se deslocar para Guaxupé perde familiaridade com o sertão, adquire “uma nova concepção do universo”, perde a esperteza que o livrara de ser assassinado por Cassiano e, por isso, simpatiza com Vinte-e-Um e é morto por este. Cassiano está renascendo no final do conto; chora, “já era outro homem”, e “a placidez 
do ambiente lhe ia adoçando a alma” (p. 164), mas seu "renascimento" torna-o ainda mais impiedoso com o desafeto.

A busca de uma identidade perdida é, segundo Maria Sylvia de Carvalho Franco, o projeto de vida no qual se empenha Matraga: “É o amor-próprio que o afunda e o retira da desgraça e todo seu caminho é realizado em direção a si mesmo.” (FRANCO, 1975, p. 104). Quim Recadeiro, que tem de si o mesmo conceito de Vinte-e-Um - "Eu, não, porque sou medroso. Eu cá pouco presto...” (p. 333) -, executa ato violento de que não se acreditava capaz e, tal como Matraga, acaba tendo também sua hora e vez. A vez e a hora de Dionóra chegam com a realização no amor, no momento da sua decisão de abandonar o marido. Como é regra em Sagarana, as mulheres trazem a vida, e os homens, a morte.

Se o termo identidade é excessivo para um animal, diremos que Sete-de-Ouros, de $O$ burrinho pedrês, recupera sua dignidade no final do conto. De Manuel Fulô trataremos quando analisarmos Corpo fechado.

Como diz Riobaldo sobre a identidade dos humanos - o que é confirmado por várias personagens de Sagarana-, “o mais importante e bonito, do mundo, é isto: que as pessoas não estão sempre iguais, ainda não foram terminadas - mas que elas vão sempre mudando. Afinam ou desafinam.” (ROSA, J. G. 1957, p. 24).

Dois fatos acima apontados sobre Cassiano - representar a instituição oficial encarregada de conter a violência que ele mesmo propaga e aproximar-se da morte para dar a morte a outro -, considerados no conjunto, abrem a possibilidade de interessante análise da personagem na esfera psicanalítica, o que certamente enriqueceria esta análise feita do ponto de vista social. No entanto, consideramos que os aspectos que aqui foram observados sejam suficientes para nosso objetivo. 


\section{MINHA GENTE}

Enquanto $A$ volta do marido pródigo põe em relevo aspectos práticos do exercício da política partidária brasileira, Minha gente suscita reflexões acerca de questões como civilização e estado de natureza e, sobre o pano de fundo da prática da política no Brasil, fornece um panorama sobre o processo civilizador. Esses temas são desenvolvidos no âmbito do público e do privado e têm como linha mestra os acontecimentos que envolvem um narrador-personagem em suas relações nos dois campos. Como conseqüência, o conto retoma questões referentes a estado de natureza e civilização, ordem e desordem, já tratadas nos outros contos até aqui analisados, porém trazidas à baila de forma mais conceitual.

Algumas inter-relações simples na narrativa dos dois contos, que funcionam como pistas, sugerem a possibilidade de estabelecer um parentesco entre eles; ambos têm personagens homônimos: Ramiro, que termina por se casar com Maria Irma em Minha gente, e o espanhol que compra a mulher de Lalino em A volta do marido pródigo; Eulálio, o Lalino, e dona Eulália, a já falecida mãe de Maria Irma; “Maria” é o primeiro nome da filha de tio Emílio e também da mulher de Lalino. Afora esses casos, as epígrafes dos dois contos falam de certa Maria - e este é o único nome próprio que é repetido nas epígrafes de Sagarana - como realizadora de façanhas muito dificultosas, para cuja realização são necessários atributos fabulosos:

“Tira a barca da barreira,

deixa Maria passar:

Maria é feiticeira.

ela passa sem molhar.”

(CANTIGA DE TREINAR PAPAGAIOS.) (p. 173).

O interesse por mulheres estrangeiras (idealizadas como fisicamente perfeitas), que levou Lalino à capital, também se manifesta na imaginação e nos devaneios do narrador de Minha gente, como na passagem em que, por despeito, ele tenta desmerecer os olhos da prima: “Olhos de Maria Irma... Bobagem, eu vou gostar mais de olhos castanhos, de olhos verdes... Suecas, húngaras, dinamarquesas... polonesas de olhos pardos...” (p. 195); ou ainda:

Meu espírito fumaceou, por ares de minha só posse - e fui, por inglas de Inglaterras, e marcas de Dinamarcas, e landas de Holanda e Irlanda. Subi à visão de deusas, lentas apsaras de sabor de pétalas, lindas todas: Dária, da Circássia; Ragna e Aase; e Gúdrun, a de olhos cor dos fiordes; e Vívian, violeta; e Érika, sílfide loira; e Varvára, a de 
belos feros olhos verdes; e a princesa Vladislava, císnea e junoniana; e a princesinha Berengária, que vinha, sutil, ao meu encontro, no alternar esvoaçante dos tornozelos preciosos... (p. 201-2)

Numa primeira visada, também podem ser observadas algumas diferenças entre as personagens dos dois contos; o caráter de tio Emílio é diverso daquele do Major Anacleto, tanto como mandante como chefe familiar; são também diversos o esperto Lalino e o pouco arguto Primo narrador; a relação amorosa do Primo com Maria Irma e com Armanda é diversa da de Lalino com as prostitutas e Maria Rita. É em decorrência dessas diversidades que os dois contos se tornam complementares.

Em A volta do marido pródigo, a maior parte da narrativa é ocupada pela política; em Minha gente, é o amor que toma a maior parcela do texto. Mas é o social que fundamenta Minha gente. Vários acontecimentos nas esferas pública e privada, sempre subordinados ao fato social, dão suporte a essa afirmação e, dentre essas manifestações, ocupam posições de destaque na narrativa: o processo político, ponto culminante da atividade humana na esfera pública, e as relações familiares e afetivas, com proeminência para o amor, o sentimento mentor das ações humanas na vida privada.

A caracterização da vida pública no conto é feita principalmente por quatro personagens: o narrador (aqui chamado de “o Primo”), Santana José Malvino e tio Emílio.

Santana é inspetor escolar; é, portanto, um homem que atua no projeto de modernização do Brasil por meio da educação, que teve início na década de 1920. Antonio Candido, em A educação pela noite, afirma que a reforma do ensino no nível federal a partir de 1930 por Francisco Campos é a continuidade dessas reformas estaduais na década anterior, e que "a escola pública leiga pretendia formar mais o ‘cidadão’ do que o ‘fiel’, com base num aprendizado pela experiência e a observação que descartava o dogmatismo”. Segundo Candido, essa noção “pareceu à maioria dos católicos o próprio mal, porque segundo eles favorecia perigosamente o individualismo racionalista ou uma concepção materialista-iconoclasta.” (CANDIDO, 1987, p. 182-3). Santana incorpora o ideal nacional moderno de educação, como descrito por Candido, e, portanto, se ocupa de importantes temas sociais, seculares e não eclesiásticos: " $E$ Santana fala: partidas fechadas... xadrez e memória... psicologia infantil... cidade e roça... escola ativa... devoção e nutrição... a mentalidade do capiau...” (p. 177). Parecenos que ele se empenha com dedicação para cumprir satisfatoriamente as muitas 
atividades exigidas por seu cargo, pois à pergunta do Primo, se apareceria na fazenda nos próximos dias, responde: “- Impossível. Tenho uma enfiada de escolas por visitar, e devo tomar o trem muito longe daqui. Até outra vez!...” (p. 185). Quanto ao temperamento, Santana é todo cerebral, contido na demonstração de emoções, "Não tem grandes expansões nem abraços” (p. 173), seu mundo é interno, intelectual, características que justificam seu enorme interesse e sua habilidade no estratégico jogo de xadrez; raciocina sempre, pois, como diz o Primo, está sempre com a mente ocupada com problemas, isolado do mundo (p. 179). Sua descrição física pelo narrador é de um indivíduo de bom caráter, rigoroso, dono de cérebro tão volumoso a ponto de não caber na caixa craniana: "Tem apenas duas bossas frontais poderosas, olhos bons, queixo forte, e riso bom em boca má. E, no mais, para ele a vida é viva, e com ele amasiada.” (p. 173-4).

Santana e o Primo se harmonizam e jogam o mesmo jogo; completam-se como o preto e o branco no tabuleiro, mas o Primo é emotivo, pouco afeito a questões sociais e tem consciência limitadíssima do que o cerca no âmbito público; aprecia a natureza no que ela tem de belo e prodigioso e, conforme é mostrado em muitas passagens do conto, deixa-se levar por afetos, cores, sons: “Na serra, verde-malaquita, arquipélagos de reses, muito alvas, pastando, entre outras ilhas, vermelhas, do capim barba-de-bode. E, nos pontos mais ínvios da encosta, tufos do catinga-de-bode florido, em largas manchas azuis.” (p. 176). Embora os dois homens sejam cultos - mencionam a Odisséia com desenvoltura e se entretêm jogando xadrez -, diferem muito na maioria dos aspectos; essa diversidade de caráter pode ser notada já a partir do momento em que se encontram na estação ferroviária:

- “Vamos! Partamos! Já Circe, a venerável, me advertiu!...” Mas Santana, que é criatura do Caraça, retrucou:

- "Vinde, amigos, perguntai ao estrangeiro se sabe ou se aprendeu, algum dia, qualquer jogo...” (p. 174).

O Primo menciona as palavras do nostálgico Ulisses nos versos 549 do canto X, pronunciadas pelo herói no momento em que desperta seus companheiros de viagem; Santana retruca com as palavras mordazes de Laodamante a respeito de Ulisses estrangeiro na ilha dos feácios como o Primo no sertão - contidas nos versos 133 e 134 do Canto VIII, e cujo sentido o leitor entenderá mais tarde, quando se dará conta da inexperiência do Primo nos jogos do amor e da política. 
Enquanto Lalino se move com desenvoltura no meio em que atua, o Primo - que desabafa: "Pororoca! Será que ninguém aqui pensa como eu?!...” (p. 200) - tropeça na maioria das frentes em que opera: na política, seu desempenho é medíocre e pouco ou nada ajuda o tio na conquista de votos; no campo afetivo, comporta-se ingenuamente e termina por se tornar o servidor involuntário da prima no obstinado projeto desta última de surrupiar o namorado de sua amiga Armanda. São fracassadas suas tentativas de mostrar sagacidade e esperteza no seu contato com José Malvino e com o moleque Nicanor. E talvez até venha a perder para Santana uma partida de xadrez que já dava por ganha. A forma desajeitada de o Primo se relacionar com várias personagens da obra faz de Minha gente o conto que trata mais apropriadamente da dificuldade dos narradores da primeira pessoa em Sagarana: homens da cidade, custa-lhes adaptar-se à mentalidade do sertanejo e ao ambiente rural. Por exemplo, escapa à sua compreensão a lógica da regra local contida no desfecho do caso de dois vaqueiros que ajudam a encontrar o boi desgarrado de um terceiro e desconhecido vaqueiro que, pouco antes, lhes atiçara marimbondos (p. 183). Já no primeiro parágrafo do conto ele enumera poucos e esparsos conhecimentos sobre a vida do sertão, quase todos referentes a cuidados para evitar dissabores, tanto no convívio com o meio como na relação afetiva com as primas - e, particularmente, com Maria Irma:

Quando vim, nessa viagem, ficar uns tempos na fazenda do meu tio Emílio, não era a primeira vez. Já sabia que das moitas de beira de estrada trafegam para a roupa da gente umas bolas de centenas de carrapatinhos, de dispersão rápida, picadas milmalditas e difícil catação; que a fruta mal madura da cagaiteira, comida com sol quente, tonteia como cachaça; que não valia a pena pedir e nem querer tomar beijos às primas; que uma cilha bem apertada poupa dissabor na caminhada; que parar à sombra da aroeirinha é ficar com o corpo empipocado de coceira vermelha; que, quando um cavalo começa a parecer mais comprido, é que o arreio está saindo para trás, com o respectivo cavaleiro; e, assim, longe outras coisas. Mas muitas mais outras eu ainda tinha que aprender. (p. 173)

No final do conto, ele abruptamente se apaixona por Armanda - filha de fazendeiro, mas também da cidade, como ele - e é por esta de imediato correspondido. Encontra aí a parceira que provém do mesmo meio que ele e troca com ela o beijo que lhe fora sempre negado por Maria Irma.

A diferença de modo de ver o mundo entre Santana e o Primo pode ser observada na passagem abaixo; o de Santana é vasto - provável explicação de sua maior aptidão no jogo de xadrez - e fala do Brasil, enquanto o do Primo é mais localizado e passa do céu - portanto, do universal - diretamente para o chão de Minas Gerais: 
Cavalgamos. Subimos. Subir mais. Agora, um lançante contínuo, serra avante em lombo longo, escalando o espigão. E, pronto, o mundo ficou ainda mais claro: a subida tinha terminado, e estávamos em notáveis altitudes. (...)

Ali, até uma criança, só de olhar ficava sabendo que a Terra é redonda. E eu, que gosto de entusiasmar-me, proclamei:

- Minas Gerais... Minas principia de dentro para fora e do céu para o chão. . .

Santana ouviu, e corrigiu:

- Por que você não diz: o Brasil?

E era mesmo. Concordei. (p. 178-80)

Em oposição intelectual a Santana e ao Primo, temos José Malvino que, embora analfabeto, sabe as leis do mundo e tem experiência de vida. Santana reconhece essa virtude no capiau: “-Veja este que vai aqui à nossa frente: é um camarada analfabeto, mas, no seu campo e para o seu gasto, pensa esperto.” (p. 177). Ele demonstra um conhecimento não acessível ao Primo, e sua capacidade dedutiva, dentro de seu campo de atividade, faz dele um Sherlock sertanejo.

De repente, o José Malvino, estacando o animal, curvou-se para examinar qualquer coisa no chão.

- Que é que você está olhando, José?

- É o rastro, seu doutor... Estou vendo o sinal de passagem de um boi arribado. A estrada-mestra corta aqui perto, aí mais adiante. Deve de ter passado uma boiada. O boi fujão espirrou, e os vaqueiros decerto não deram fé... Vigia: aqui êle entrou no cerrado... Veio de carreira... Olha só: ali ele trotou mais devagar...

- Mas, como é que você pode saber isso tudo, José? indagou Santana, surpreso.

- Olha ali: o senhor não está vendo o lugarzinho da pata do bicho? Pois é rastro de boi de arribada. Falta a marca da ponta. Boi viajado gasta a quina do casco... Eles vêm de muito longe, vêm pisando pedra, pau, chão duro e tudo... Ficam com a frente da unha roída... É diferente do pisado das reses descansadas que tem por aqui...

Não consigo dissociar alguma coisa nas pegadas. (ps. 181-2).

Os conhecimentos das três personagens, Santana, o Primo e José Malvino, se completam com a capacidade de "ver tudo de longe" - como Santana e, em âmbito mais restrito, o Primo -, mas também de perceber os pormenores, "pelo rastro do chão", como literalmente faz José Malvino. Ver de longe e de perto para conhecer o mundo é o que faz o Major Saulo, de O burrinho pedrês.

A outra personagem com papel significativo na esfera pública em Minha gente é tio Emílio. O Primo afirma que, antes de chegar à fazenda, guardava dele péssima memória, a de um homem desajeitado, apático, lento, sem pressa. Agora já não é apático como dantes, mas continua calmo e fechado, mostrando cautela nas palavras e 
reserva em expor sentimentos publicamente, virtudes essenciais para o exercício da política. Seu salto da inanição para a dinâmica do progresso, no entanto, não será completo e isento de antagonismos. Ao mesmo tempo em que adquire uma máquina de escrever moderna (p. 208), em suas relações na esfera pública prevalecerão sempre marcas do arcaísmo persistente nas relações políticas no Brasil. Ele enfrenta a oposição de um jovem médico que representa uma vaga de modernidade, e esse médico é a causa provável da mudança de tio Emílio, porque ameaça o prestígio político do mandante. O narrador, seja por afeto ao tio, seja por sua propensão à acomodação, não mostra simpatia por esse adversário político e fala da indecisão do povo do arraial, que “obedece ao médico, um doutor moço e solteiro, pessoa portanto sem nenhuma urgência, que tarda a se definir.” (p. 188 -9).

A política praticada por tio Emílio - e de modo geral pelos mandantes locais em outros contos de Sagarana - é regida por relações pessoais e partidárias confusas e instáveis porque conduzidas mediante complicados arranjos que com freqüência geram atritos e desacertos. Ao discorrer sobre essas relações, o Primo se refere à área de influência do tio como um “feudo":

Política sutilíssima, pois ele faz oposição à Presidência da Câmara no seu Município (n. ${ }^{\circ}$ 1), ao mesmo tempo que apóia, devotamente, o Presidente do Estado. Além disso, está aliado ao Presidente da Câmara do Município vizinho a leste (n. ${ }^{\circ}$ 2), cuja oposição trabalha coligada com a chefia oficial do município ${ }^{\circ} 1$. Portanto, se é que bem o entendi, temos aqui duas enredadas correntes cívicas, que também disputam a amizade do situacionismo do grande município ao norte (n. ${ }^{\circ}$ 3). Dessa trapizonga, em estabilíssimo equilíbrio, resultarão vários deputados estaduais e outros federais, e, como as eleições estão próximas, tudo vai muito intenso e muito alegre, a maravilhas mil. (p. 188).

Mas, aqui neste nosso feudo, grande é o prestígio do meu grande tio Emílio. Seu agrupamento domina a zona das fazendas de gado, e manda na metade da vila. (p. 188)

A força política dos detentores locais do poder é aproveitada pelo presidente do Estado para fortalecimento de sua base eleitoral. Por outro lado, a prerrogativa do presidente de designar o comando da justiça dos municípios é aproveitada por tio Emílio para atender a seus interesses eleitorais. Quando tal prerrogativa apresenta resultados políticos desfavoráveis, ele reage indignado e fala em compressão e suborno:

Tio Emílio pediu-me que redigisse um telegrama ao Secretário do Interior, solicitando a substituição do comandante do destacamento policial da vila, que, por sinal, já foi cambiado duas vezes, nestes seis meses derradeiros. Porque, lá na Capital, sabem montar à cossaca; em dois ginetes, e as duas facções são atendidas rotativa e relativamente. Enquanto isso, o tempo passa, o pau vai e vem, e folgam os filhos da sabedoria. Mas, às 
vezes, meu tio bate com o rebenque na bota, e fala em "compressão e suborno"; depois, suspira e comenta a degenerescência dos usos e a sua necessária regeneração. (p. 190).

O Primo associa a atividade política do tio às habilidades da caça e da pesca, atividades que se distinguem pelo benefício imediato que trazem, ao contrário do que ocorre na agricultura e na pecuária; a prática da política é, portanto, associada a uma atividade em que se buscam resultados instantâneos: "O político pensa apenas em minutos” (COUTINHO, 1991, p. 78), dirá Rosa a Gunther Lorenz. Além disso, ao identificar caça e a pesca com a política, o narrador ressalta a astúcia e a paciência exigidas na perseguição ao voto. Ele assim se refere à aptidão do tio para a política:

Santana costuma dizer: - Raspe-se um pouco qualquer mineiro: por baixo, encontrar-se-á o político...

Para mim, não é bem isso. Tanto mais que ninguém raspou tio Emílio. Mas, acontece que ele sempre gostou de caçar e de pescar. E, de tanto ver a paca apontar da espumarada do poço, bigoduda e ensaboada como um chinês em cadeira de barbeiro... E de se emocionar com a ascensão esplêndida da perdiz, levantada pelo perdigueiro, indo ar acima, quase numa reta, estridulante e volumosa, para se encastelar... E de descair o anzol iscado, e ficar caladinho, esperando o arranco irado da traíra ou os puxões pesados do bagre... Bem, afinal, pode ser que seja Santana quem tenha razão. (p. 189).

Para manter e consolidar o poder político, Tio Emílio emprega na campanha grande parte dos recursos financeiros de que dispõe: “- O pior foi que eu tive um prejuízo grande. Gastei para mais de uns oitenta contos... Um estrago!... Estou pensando em fazer um acordo na política, em desde que eu fique sendo o chefe...” (p. 221). Obviamente, tal acordo político, pelo fato de ser realizado com o fito explícito de recuperar o dinheiro gasto em campanha, só pode vir atrelado a “compressão e suborno”, como ele mesmo diz. Curiosamente este é em Sagarana um caso único de declarada corrupção, essa prática inabalável na política brasileira; parece-nos que Guimarães Rosa teria a possibilidade de mostrar a corrupção política nos dois contos em que a figura do político é explorada em profundidade, mas escolheu justamente a personagem de tio Emílio, em quem ela parecia menos provável.

Como ativista da cordialidade, os interesses privados de Tio Emílio se sobrepõem aos interesses coletivos e, quando ele atende à necessidade da comunidade ou ao interesse particular de seus eleitores, mira exclusivamente a obtenção de votos; é o que acontece, por exemplo, com sua decisão no caso do assassínio de Porfírio por Alexandre, o Xandrão Cabaça:

Chamou o Norberto, o capataz, e mandou, que fosse ver o corpo. E que corresse alguém ao arraial, para chamar o subdelegado. 
O capataz saiu, convocando os camaradas. Meu tio se chegou para o parapeito, e tirou o fumo mais o canivete.

Não me contive:

- Mas, tio Emílio, o senhor que é tão justiceiro e correto, e que gostava tanto do Bento Porfírio, vai deixar isto assim? Não vai mandar depressa, gente atrás do Alexandre, para ver se o prendem?

Tio Emílio, alisando a sua palha, e com o sorriso que um sábio teria para uma criança, olhou-me, e disse:

- Para os mortos... sepultura! Para os vivos... escapula!..

Humilhei meus pendões. Calei- me. Meu tio esfregava nas palmas das mãos o fumo picado. Enrolou o cigarro. De súbito, bateu na testa, e pulou:

- Não é que eu não sei onde é que eu estava mesmo com a cabeça?! Ô Gervásio, corre aqui!... Já perdi um voto, e, se o desgraçado fugir para longe, são dois que eu perco... (p. 199).

Lança mão de seu poder econômico na compra de votos: “Tio Emílio não cessa de receber gente. Expede portadores, e, até fora d'horas na noite, costumam chegar emissários. O número de camaradas e agregados aumentou: na fazenda, atualmente, não se recusa trabalho, nem dinheiro, nem nada, a ninguém.” (p. 189). Utiliza também seu poder político para influenciar a decisão judicial em favor do assassino Alexandre, seu eleitor: “- Agora a gente tem é de ver os jurados, para o júri do leso do Xandrão Cabaça...” (p. 200). Aproveita o funeral de Bento Porfírio para mostrar generosidade com a viúva e com a mulher que motivou a tragédia: "Chovia, na verdade, porém, a chuva não impediu Maria Irma de sair, para visitar e confortar a viúva e a outra. Meu tio também se mostrou assaz generoso para com as duas. Minha gente é boa.” (p. 201) passagem que não deixa claro se a visita da prima às duas mulheres tem fundo humanitário ou alguma razão política, ou tudo isso ao mesmo tempo, mas mostra a cegueira do Primo para a real motivação da aparente generosidade do astuto tio Emílio. Essa mesma astúcia ele utiliza para tirar proveito da ingenuidade do sobrinho, quando quer obter informações sobre o andamento da campanha de seu concorrente político, Juca Soares (p. 213-6), o que faz o Primo desabafar: “Oh, céus! Até a minha inocente ida ao Juca Soares foi explorada em favor das manobras políticas do meu tio.” (p. 216)

Tio Emílio procura trocar apoio político com Don’Ana do Janjão, a mulher que efetivamente comanda a fazenda Panela-Cheia. Para tanto, tira proveito da fé religiosa dos eleitores, como já fizera o Major Anacleto. A passagem abaixo mostra a prática da cordialidade sob várias formas, sempre com o objetivo de afirmação de poder político, prática que inclui até mesmo a promoção de um inepto à patente de coronel e a mudança 
de seu estatuto de bobo para boa pessoa. Além disso, transparece no diálogo a escassa confiança - justificada, como se vê - que o tio tem no discernimento do sobrinho em assuntos de política:

- Vamos escrever à Don’Ana do Janjão, da Panela-Cheia! Carta grande, palavreado escolhido. E outra para o bobo do marido... Mas não bota nada de que ele é bobo, aí, não, hein!?...

- Carta simples, tio Emílio? Só para cumprimentar?

- Não. É avisando que eu troquei duas imagens para a capelinha do Retiro. Santa Ana e São João... E, como foi em honra deles dois, que são meus amigos, faço questão de que eles sejam os padrinhos!... Põe, na carta, que eu considero muita honra. Vou fazer festa: música, missa cantada, o diabo!(...).

- Mas, meu tio, essa graciosa homenagem vai render-lhe pouco serviço... Os eleitores de Don’Ana do Janjão sendo de outro município. . .

- Ora, que idéia, meu sobrinho! Então você pensa que é só por interesse que a gente agrada as pessoas de quem a gente gosta?... E mesmo que fosse... Mesmo que fosse, tem muita gente, da banda de cá das divisas, que morre para obedecer à minha comadre Don’Ana...

- Comadre?

- Uê! Pois não vai ser?... Ela mais o marido, que é muito boa pessoa, não vão batizar as imagens que eu mandei vir para a capelinha? Pode escrever, pode pôr na carta: "Minha ilustríssima e prezada comadre...” e na outra: "querido e estimado compadre Coronel Janjão”. Ele não é coronel nenhum, mas não faz mal... Muito distinta, a comadre Don’Ana... É capaz de querer fazer com a gente um trato por fora: ela manda o pessoal dela por aqui votar comigo, e eu faço o mesmo com o povinho que tenho por lá, no Piau... (...)

- Pergunta como é que vai o Juquinha... Juquinha é o ai-jesus dela, é um menino que a minha comadre Don'Ana está criando.(208-10)

Vale abrir um parêntese para destacar, nesse episódio, um aspecto digno de nota no que diz respeito ao papel das mulheres em Sagarana. A representação da sociedade patriarcal no livro é consubstanciada no exercício do poder pelos homens, como regra geral, mas reforçada de forma categórica no fato de Don'Ana, mulher que detém com mérito o poder na Panela-Cheia, ter seu nome atrelado, como um bem material, a um homem apatetado, como se dele fora propriedade. Como discreto reconhecimento do público por sua condução efetiva da fazenda, ela tem também o seu nome mencionado junto ao do marido, e ele é chamado de Janjão do Don’Ana. O nome da fazenda sugere uma opulenta atividade culinária própria de mulheres. 
As quatro personagens que acima focalizamos - Santana, o Primo, Malvino e Emílio - compõem um quadro geral das tendências da vida pública no Brasil. Ao lado de um homem teórico como Santana, que atua na crença da educação como mola propulsora da civilização e do progresso, temos um José Malvino, analfabeto, místico e supersticioso, porém conhecedor profundo do meio onde se move. Junto ao mesmo Santana, encontramos o Primo, pouco consciente dos temas básicos de um processo civilizador, como educação e política. A política praticada por tio Emílio - com todos os temperos característicos da política nacional já acima referidos - prática da cordialidade, exercício do poder econômico, compadrio, jogo de influências, troca de favores, corrupção, manipulação da justiça e da polícia com fim eleiçoeiro - é um fator que perpetua o atraso; e as tentativas de combater esse atraso não têm resultado, pois não ultrapassam os limites da compra de uma máquina de escrever para remeter carta a “insignes analfabetos” (p. 208), ou de uma eleição que pouco ou nada representa em termos de escolha popular porque, na sua essência, simplesmente valida o poder de quem o ostenta. O médico, que poderia trazer alguma forma de modernidade, é derrotado pelas forças do atraso, representadas por tio Emílio.

A vida privada em Minha gente nos é mostrada pelos sucessos vividos no campo do amor principalmente por quatro personagens: o Primo, Maria Irma, Bento Porfírio e de-Lurdes. Contudo, procuraremos mostrar que a análise do desenrolar e do desfecho de cada uma dessas relações amorosas fornece elementos importantes para a discussão conceitual dos fatores que sustentam ou obstam o processo civilizador de determinada sociedade. O âmbito abrangido por essas discussões é menos local e mais universal, como se verá, ficando a discussão no âmbito nacional por conta das atividades sociais das quatro personagens masculinas acima referidas.

O Primo corteja Maria Irma, mas esta consegue arranjar o casamento do primo com Armanda e casa-se com Ramiro, noivo de Armanda. Por outro lado, Bento Porfírio, amante de sua prima de-Lurdes, é assassinado por Alexandre, marido desta última. O que os dois casos têm em comum é que Maria Irma e Alexandre impedem a união entre primos: a primeira com o emprego da inteligência e da argúcia feminina, e o segundo, com a violência masculina.

Um episódio transcorrido num galinheiro, metaforiza a divisão de tarefas entre homens e mulheres mencionada por Clastres, que vimos quando analisamos $O$ burrinho pedrês: 
Um gordo galo pedrês, parecendo pintado de fresco com desenhos de labirinto de almanaque, sultaneava, dirigindo preferências a uma galinha ainda mais carijó e mais gorda, vestida de fichas de impressão digital. E veio de lá, ciumento e briguento, outro galo, esse branco, com chanfraduras e pontas na crista caída de lado. Barulho. E então a galinha choca, com cloqueios e passos graves, chamou os pintinhos para longe dali. (...).

Mas, de supetão, uma espécie de frango esquisito, meio carijó, meio marrom, pulou no chão do terreiro e correu atrás da garnisé branquinha, que, espaventada, fugiu. O galo pedrês investiu, de porrete. Empavesado e batendo o monco, o peru grugulejou. A galinha choca saltou à frente das suas treze familiazinhas. E, aí, por causa do bico adunco, da extrema elegância e do exagero das garras, notei que o tal frango era mesmo um gavião. (p. 205).

No primeiro parágrafo, dois machos lutam pela supremacia do amor de uma fêmea, como acontece entre as os humanos de Sagarana, enquanto esta trata de afastar sua ninhada do local para protegê-la da violência do embate dos machos. No segundo parágrafo, a situação se repete, com a diferença de que um dos contendores é um gavião; o comportamento da galinha, que antes era defensivo, agora é o de enfrentamento para preservar a vida de seus pintinhos. Ainda no segundo parágrafo, vemos as movimentações de ataque e de defesa do peru, do galo e do gavião: machos em luta de morte, fêmea na preservação da vida da sua prole.

Voltemos às relações afetivas entre os primos. Nas idéias comumente disseminadas sobre eugenia na primeira metade do século $\mathrm{XX}$, o casamento entre consangüíneos era considerado prejudicial porque, ao aumentar a probabilidade de geração de filhos geneticamente malformados, do ponto de vista físico ou mental, representava risco para a espécie humana e, por conseguinte, para a civilização. ${ }^{21}$ Freud, focalizando o assunto sob o ângulo social, e não genético, numa carta que enviou a Fliess em 1897, ressaltou o fato de o incesto ser prática anti-social porque as relações incestuosas isolam o grupo familiar do restante da sociedade. Freud se referia principalmente ao incesto como união sexual legalmente proibida entre irmãos e entre pais e filhos, mas o fato de, em Minha gente, uma união consumada entre primos conduzir à tragédia e outra ser sabiamente evitada faz supor que em Sagarana a tese de

${ }^{21}$ O manual de Renato Kehl, Como escolher um bom marido, preconizava evitar o casamento consangüíneo. Antes, em 1919, Elói de Souza e Álvaro de Carvalho apresentaram ao Senado projeto que propunha em seu artigo $1^{\circ}$ a proibição de casamentos entre os irmãos legítimos ou ilegítimos e os colaterais legítimos ou ilegítimos até o terceiro grau inclusive, salvo, para estes, dispensa ou licença judicial. (Apud Castañeda, Luzia Aurélia. Eugenia e casamento in História, Ciências, SaúdeManguinhos vol.10 nº3. Rio de Janeiro, Setembro/Dezembro 2003). 
Freud sobre o isolamento social é aplicável também nas uniões entre primos, porque provocam o mesmo efeito social:

O horror ao incesto (como coisa ímpia) baseia-se no fato de que, em conseqüência da comunidade da vida sexual (mesmo na infância), os membros de uma família se mantêm permanentemente unidos e se tomam incapazes de contatos com estranhos. Assim, o incesto é anti-social - a civilização consiste nessa renúncia progressiva. (FREUD, 1987, vol 1, p. 277).

Um aspecto subsidiário ao considerado por Freud é que a união consangüínea, ao provocar o isolamento social da família, tende a perpetuá-la no exercício do poder, nas famílias que o detêm, ocasionando desse modo a tendência ao conservadorismo ou à estagnação social.

Poderíamos pensar nesses dois aspectos para explicar o fato de, em Minha gente, não se consumarem as uniões entre primos. Haveria motivo para se pensar em impedimento eugênico, em vista da atualidade do tema na ocasião em que foram escritos Sezão e Sagarana, mas a hipótese do isolamento social deve também ser seriamente levada em conta. Em primeiro lugar, a possibilidade de se interpretar o interesse do Primo pela prima em termos incestuosos é sugerida pela própria semelhança gráfica e fônica de "Irma” com “irmã”; em segundo lugar, a tendência de repúdio ao isolamento social é exemplificada no episódio - contado por José Malvino do varioloso que “conheceu que ia morrer, e implorou que o enterrassem bem à beira da estrada, onde o povo passasse, onde houvesse sempre gente a passar...” (p. 184).

A hipótese do isolamento social, que estamos defendendo como a de maior interesse no conto, é inerente ao pensamento de Pierre Clastres: "Por certo, a troca é imanente ao social humano: há sociedade humana porque há troca de mulheres, porque há proibição do incesto.” (CLASTRES, 2004, p. 264). À luz desse conceito, as manobras de Maria Irma podem ser metaforicamente compreendidas como modo de preservação da sociedade e de impedimento do retorno ao estado de natureza. A passagem do galinheiro termina com um diálogo entre os primos, no qual Maria Irma mostra ao Primo a distinção entre o ser humano civilizado e o animal.

- Nunca pensei que um gavião pudesse ser tão covarde e idiota... - eu disse.

Maria Irma riu.

- Mas este não é gavião do campo! É manso. É dos meninos do Norberto... Vem aqui no galinheiro, só porque gosta de confusão e algazarra. Nem come pinto, corre de qualquer galinha...

- Claro! Gavião civilizado...

- U’lalá... Perdeu duas penas... 
O sorriso de Maria Irma era quase irônico. Não me zanguei, mas também não gostei. (p. 205-6)

O narrador-personagem, por troça, interpreta a mansidão e o medo do gavião como sinal de civilização - por se considerar civilizado, ser manso e ter medo de uma fêmea; mas Maria Irma responde evidenciando a separação nítida entre o animal e o humano e afirma que a “civilização” do gavião, ao contrariar sua natureza selvagem, fêlo perder duas penas. Distinguir animais de humanos significa distinguir os homens que baseiam seu comportamento em um contrato social estabelecido em uma sociedade civilizada daqueles que se comportam como bichos, seja praticando a violência, seja praticando o incesto. A mesma distinção entre animal e humano será feita pelo moleque Nicanor, como veremos adiante.

No diálogo acima, como em todos os outros entre as duas personagens, Maria Irma mantém sempre o controle da situação e a presença do gavião caiu apropriadamente, pois a fêmea dessa ave é mais forte que o macho. As atitudes da jovem têm duas feições opostas: por um lado, ela faz um jogo amoroso para atraí-lo e mantê-lo sob total controle e, por outro, conserva-o a respeitosa distância, que o impede de avançar em suas expansões de afeto. Esse comportamento ambíguo leva-a, simultaneamente, a avivar e a desfazer as esperanças do Primo na relação afetiva. A ambigüidade de vida e morte de amor habilmente mantida por Maria Irma é metaforizada na passagem que transcrevemos a seguir; nela, o Primo fala do amor que sobe e desce como peso nas duas conchas de uma balança (adiante veremos outra passagem em que o órgão sexual feminino é simbolizado pela concha). A passagem fala da prima, da lua e da vida - sendo esta representada por árvores, riacho e vacas geradoras de bezerros. Mas, ao mesmo tempo, fala do estado de violência animal, ao se referir aos pisoteios e à movimentação desordenada do gado no curral. A passagem, portanto, estabelece a livre associação de idéias do narrador não somente entre a prima - foco permanente desse trecho - com a lua e com a vida, mas também com a possibilidade da geração de desordem do estado de natureza; parece razoável concluir, pelo que dissemos anteriormente, que a desordem a que a passagem se refere consiste no risco do incesto:

Pensava: será que agora, com a minha ausência, Maria Irma não estaria começando a gostar de mim? E penava com isso, que o amor, ao contrário de acontecer como a água em dois vasos estanques, deva gangorrar como pesos em conchas de balança. E desesperava, ao sentir que eu acumulara comigo tanto amor que estava inútil, sem ter onde pousar. 
Mais sofri, todavia, porque lua havia, uma lua onde cabiam todos os devaneios e em que podia beber qualquer imaginação. Da varanda, eu espiava um pedaço, dado ao luar, de ar claro; as árvores ficavam tão quietas, que aquele campo parecia correr, como um vau de riacho raso, de transparência movente. As vacas, àquela hora, mugiam imenso, apartadas dos bezerros. Os dias me cansavam muito, mas eu não conseguia dormir. Pelas frinchas da janela, entrava o mato em insônia, com vozes que eu não entendia. E, às vezes, tarde na noite, ouvia, do curral, bruscos estrépitos - bufos, pisoteios, e um trafegar a esmo excursões do gado sonambúlico.

E eu pensava, sempre, em Maria Irma. (p. 218).

Examinemos agora outra passagem do conto:

- Você faz tudo como devia fazer... Só, às vezes, isso me dá raiva... Mas eu gosto que você seja mesmo assim...

Fechei-me no quarto. Pela janela aberta entrava um cheiro de mato misantropo. Debrucei-me. Noite sem lua, concha sem pérola. Só silhuetas de árvores. E um vagalume lanterneiro, que riscou um psiu de luz.

Por que será que Maria Irma mudou de maneira?...(p. 194).

Na frase "Noite sem lua, concha sem pérola” o afastamento de Maria Irma do Primo é relacionado à ausência da lua e à ausência de pérola em uma concha. A concha possui forma que remete ao órgão sexual feminino e o seu conteúdo eventual, a pérola, possivelmente tenha suscitado a lenda no nascimento de Vênus saída de uma concha. Portanto, a concha com a pérola é símbolo ao mesmo tempo erótico e fecundante. Por outro lado, a fertilidade dos animais, como a das plantas, segundo Mircea Eliade, está submetida à lua (ELIADE, 2002, p. 135). A frase, portanto, ao se referir à ausência da lua e da pérola na concha, contém a eliminação da fecundidade pela não-consumação da união dos primos, ao mesmo tempo em que mantém o sentido erótico da concha.

A lua será novamente nomeada quando o narrador conhece Armanda e imediatamente se apaixona por ela. Uma lavadeira entoa uma cantiga que fala de lua a esconder-se e de sol a raiar; é a definitiva separação entre Maria Irma e o Primo:

"De madrugada,

quando a lua se escondia. . .

o sol raiava

na janela de Maria...”

A assimilação de Maria Irma a uma hierofania lunar pode ser muito útil para a compreensão da função dessas duas personagens na trama, desde que tomados os cuidados necessários a qualquer interpretação baseada em símbolos. Por ser senhora de todas as coisas vivas e guia dos mortos, a Lua tece todos os destinos: 
Não é à toa que ela é concebida nos mitos como uma enorme aranha - imagem que encontramos em muitos povos. Tecer não significa somente predestinar (no plano antropológico) e reunir simultaneamente realidades diferentes (no plano cosmológico), mas também criar, fazer sair da sua própria substância, como o faz a aranha, que urde, ela própria, a sua teia. Não é a Lua criadora inesgotável de formas vivas? Mas, como tudo o que foi “tecido", as vidas são colocadas num conjunto: elas têm um destino. As Moirai, que fiam os destinos, são divindades lunares. (ELIADE, 2002, p. 149).

O que temos visto até aqui da personagem de Maria Irma encaixa-se bem nesses aspectos associados ao mito lunar. Em primeiro lugar, porque ela é a dona do destino do Primo, que se debate, inutilmente, para fugir a um desfecho previamente definido; mas esse desfecho, no final das contas, foi o melhor possível porque rompeu a possibilidade catastrófica do incesto. Em segundo, porque, como se viu na passagem da página 218, o narrador faz a livre associação de Maria Irma à vida, à fertilidade, à lua, mas também ao estado de natureza. O Primo narrador, como nos demonstram essas associações de idéias, oscila permanentemente entre a ordem e a desordem, entre o avançar ao estado de natureza e dele recuar, entre salvar-se e quase perder-se. Essa condição antagônica, em que o protagonista se debaterá constantemente, é amplamente demonstrada na obra, como veremos a seguir.

Comecemos pelos impulsos sexuais do Primo que se manifestam em algumas passagens do conto. Destas, mencionaremos duas. Na primeira, a associação de idéias do narrador entre o jorro da mangueira e sua excitação sexual é percebida pela arguta prima:

Eu apertava com força o tubo da mangueira, e o jorro, numa trajetória triunfal e libertada, ia golpear os recessos das plantinhas distantes. De repente, notei que estava com um pensamento mau: por que não namoraria a minha prima? Que adoráveis não seriam os seus beijos... E as mãos?!... Ter entre as minhas aquelas mãos morenas, um pouquinho longas, talvez em desacordo com a delicadeza do conjunto, mas que me atraíam perdidamente... Acariciar os seus braços bronzeados... Por que não?...

Súbito, notei que Maria Irma se ruborizava. E arrebatou-me a borracha, com rudeza quase:

- Não faz isso, que você está tirando a terra toda de redor dos pés de couve! (p. 203).

A outra passagem ocorre quando o Primo faz sua segunda pescaria com Bento Porfírio, pouco antes de este último ser assassinado por Alexandre. Aqui a genitália feminina, a "valva”, é mentalmente associada a períodos geológicos, a fósseis, à poesia e ao termo indígena "itã" para designar concha, o que mostra a preeminência do amor 
sensual em todas as épocas, em todos os povos e como inspiradora final da arte e da ciência: "Não escuto mais. Estou namorando aquela praiazinha na sombra. Três palmos de areia molhada... Um mundo!... Que é aquilo? Uma concha de molusco. Uma valva lisa, quase vegetal. Carbonífero... Siluriano... Trilobitas... Poesia... Mas este é um bicho vivo, uma itã. No córrego tem muitos iguais...” (p. 197).

O risco da volta ao estado de natureza decorrente da obediência ao instinto sexual incestuoso do Primo pela prima é didaticamente mostrado nas duas pescarias com Bento Porfírio:

Os poços grandes são apenas três: o de cima serve de piscina para os camaradas; no do meio, de água limosa, mora um jacaré ermitão, de vida profunda, que deve ser verde e talvez nem exista; o último, aonde vamos, é o poção.

Ali, há uma gameleira, digna de druidas e bardos, e, na coisa água, passante, correm girinos, que comem larvas de mosquitos, piabas taludas, que devem comer os girinos, timburés ruivos, que comem muitas piabinhas, e traíras e dourados, que brigam para poder comer tudo quanto é filhote de timburé. Boa sombra e bom pesqueiro... Descemos para lá, colhendo goiabas bichadas, pisando o capim com cautela para evitar o bote de algum "bicho mau sem pernas" - e erguendo as varas, com jeito, para livrar os anzóis da ramaria baixa. (p. 191-2)

O poço de cima é assimilado aos seres humanos que se realizam como “camaradas”, ou seja, amigos, companheiros, aqueles que vivem em harmonia e na ordem. O poço de baixo é a metáfora do estado de selvageria; é o local da "guerra de todos contra todos”, já fartamente referido anteriormente, onde mora a serpente, o "bicho mau sem pernas", de ampla e contraditória simbologia, que o cristianismo associa tanto à traição como à tentação da carne.

No segundo poço habita um jacaré, que o livro de Jó (3.8) identifica ao leviatã, um dos monstros do caos inicial aparentado do dragão e da serpente. Porém, o fato de ele poder ou não existir no segundo poço indica que tudo o que ele representa também pode ou não existir. Se sua presença no conto for figura da condição do ser humano, como é regra em Sagarana, podemos interpretar essas possibilidades de ele existir ou não como a possibilidade de o homem elevar-se ao nível dos camaradas, que são usuários do primeiro poço, ou de retroceder ao estado de natureza, representado pelo terceiro poço. E é este terceiro poço que os dois homens escolhem para sua pescaria e onde Bento Porfírio confessa seu amor, “Uma paixão da brava” (p. 192), isto é, amor animal. Por outro lado, a água chega ao poção por um túnel de verdura e corre, portanto, escondida sob uma vegetação enganadora e traiçoeira. No local em que o Primo pesca 
reina o estado de natureza, e "as piabas não virão, porque, neste recôncavo escuro, sem correnteza, deve morar, numa loca, debaixo do tronco podre, uma traíra feroz.” (192). Vimos na análise de $O$ burrinho pedrês que, na literatura americana, para Franklin de Oliveira, o escuro é símbolo da queda, das forças demoníacas etc., e é nessa conotação que ele aparece no segundo verso do canto I do Inferno de Dante - “Da nossa vida, em meio da jornada, / Achei-me numa selva tenebrosa, / Tendo perdido a verdadeira estrada.” (ALIGHIERI, Inferno, Canto I, 1-3) ${ }^{22}$; mas em Sagarana o escuro simboliza principalmente os instintos do homem. Quer como símbolo do inconsciente, quer como símbolo do inferno ${ }^{23}$ - ou de um relacionado diretamente com o outro -, dessa passagem se depreende a idéia de que o escuro em que vive a traíra, a “traição”, simboliza no homem tanto seus instintos como o risco de perder-se. E instintos e perdição se misturam, porque no conto a obediência aos primeiros leva ao segundo. Mas, juntamente com o estado de natureza, que socialmente é fator de desordem e de atraso, reina também o outro causador do retrocesso social, o “espírito do Calundú”, que vai se apossando gradualmente dos dois homens. Fala-se novamente aqui em sabiá, em romantismo, em saudade, em violão:

Oh, tristeza!...Da gameleira ou do ingazeiro, desce um canto, de repente, triste, triste, que faz dó. É um sabiá. Tem quatro notas, sempre no mesmo, porque só ao fim da página é que ele dobra o pio. Quatro notas, em menor, a segunda e a última molhadas. Romântico.

Bento Porfírio se inquieta:

- Eu não gosto desse passarinho!... Não gosto de violão...De nada que põe saudades na gente.

Inútil nos defendermos, Bento! A tristeza já veio, já caiu aqui perto de nós. Eu estou pensando... Talvez, num lugar que não conheço, aonde nunca irei, more alguém que está à minha espera... E que jamais verei, jamais...

Bento ficou sério. Até mais simpático. E suspirou:

\footnotetext{
${ }^{22}$ Nel mezzo del cammin di nostra vita. mi ritrovai per una selva oscura ché la diritta via era smarrita. (ALIGHIERI, Inferno, Canto I, 1 - 3)

23 Nos Estudos para obra que se encontra no IEB-USP, há uma série de anotações de Rosa sobre a Commedia. No documento E7, Rosa fez uma anotação sobre a escuridão e a descida no canto 4.13 do Inferno:

«Or discendiam qua giù nel cieco mondo», no mundo cego=no inferno.

${ }^{23}$ Così discesi del cerchio primaio giù nel secondo, che men loco cinghia, e tanto più dolor, che punge a guaio. (ALIGHIERI, Inferno, Canto V, 1 - 3)
} 
- Estou me alembrando da minha mãe... Morreu longe daqui. Ai, minha mãezinha, dando de comer às galinhas, na porta da cafua de beira da estrada, lá no Aporá!... (193).

A segunda pescaria dos dois homens se efetua no mesmo local da primeira, no poço de baixo. Este poço, antes associado ao estado de guerra generalizada, é desta vez também significativamente assimilado pelo Primo ao mistério dos olhos de Maria Irma:

Porque todos os córregos aqui são misteriosos - somem-se solo a dentro, de repente, em fendas de calcário, viajando, ora léguas, nos leitos subterrâneos, e apontando, muito adiante, num arroto ou numa cascata de rasgão. Mas o mais enigmático de todos é este ribeirão, que às vezes sobe de nível, sem chuvas, sem motivo anunciado, para minguar, de pronto, menos de uma hora depois. Há, contínuo, aqui ou acolá, um gluglu, um chupão líquido, água rolando n’água; lá embaixo, nas pedras, a corredeira se apressa ou amaina; mas o som nunca é o mesmo de dois instantes atrás.

Os mangues da outra margem jogam folhas vermelhas na corrente. Descem como canoinhas. Param um momento ali naquele remanso, perto das frutinhas pretas da tarumã. Olhos de Maria Irma... (p. 196)

Como na primeira pescaria, o “espírito do Calundú” baixa sobre os dois homens, como se pode observar na passagem abaixo, em que mais uma vez se apresenta o sabiá:

O ribeirão mudou de tom. Você ouviu, Bento? Ronca. Está se enchendo outra vez, sem turvar a água... De repente, o sabiá! Veio molhar o pio no poço, que é um bom ressoador. E quer passar a sua tristeza para a gente.

Mas, agora, já sabemos nos defender. Podemos desmerecê-lo, quebrar-lhe a potência de acumulador de mágoas e espalhador de saudades. E, sem nenhuma combinação:

Eu disse:

- Gênero turdus... Um flavipes ou rufiventris...

E Bento berrou:

- Ô bicho enjoado! Vai chamar chuva noutra parte!... A modo e coisa que está botando ovo e veio comer minhoca de beira de corgo... Cruz!

E cantou, alto, para abafar os lamentos do outro:

“Ouvi um sabiá cantando

na beira do ribeirão...

Ó pássaro que canta triste!

Não me traz consolação..."

Então o sabiá calou o bico e foi-se embora, porque a cantiga do Bento ainda era mais melancolizante.

Agora é o córrego que parece triste. Trocou outra vez de toada... Deve ter uma lavadeira lavando roupa e chorando, lá longe, lá longe, lá para trás dos morros frios, onde há outras roças, outra gente, outro sabiá... (p. 197) 
Bento Porfírio diz que “peixe é bicho besta, que morre pela boca...” (p. 197). Ele, pouco cauteloso com respeito a seu caso extraconjugal, fala em demasia sobre seu amor pela prima de-Lurdes e é assassinado por Alexandre.

O caso do poção de Minha gente é a mais didática demonstração de sólida ligação entre estado de natureza e o "espírito do Calundú” em Sagarana. Aqui ambos são apresentados de maneira conjunta; o “espírito do Calundú” é diretamente identificado ao Romantismo na primeira pescaria e, nas duas idas ao poção, ressoa a Canção do exílio, graças às referências ao sabiá, à tristeza e à saudade do lar da infância. Confirma-se então a noção já referida anteriormente neste trabalho.

Ainda ligado ao estado de natureza e ao "espírito do Calundú”, ocorre o episódio em que o moleque Nicanor dá ao Primo uma lição de sabedoria de domínio da violência animal por meio de um projeto definido (p. 211-3), apaziguando o instinto agressivo do cavalo Vira-Saia. Dominado este, o moleque diz que bicho é uma coisa e gente é outra, “Já se viu cavalo nenhum ser irmão de gente?!...” (p. 213). Segundo Diel, “o cavalo representa os desejos impetuosos (...). Assim como doma e dirige o cavalo, o homem deve poder domar seus desejos.” (DIEL, 1991, p. 88). Se a esta simbologia juntarmos as palavras do padre que confessa nhô Augusto em A hora e vez de Augusto Matraga "Modere esse mau gênio: faça de conta que ele é um poldro bravo, e que você é mais mandante do que ele...” (p. 339) - e ainda o fato de que moleque Nicanor reconhece que um outro cavalo, o Caraúna, é difícil de domar porque não é castrado, podemos adicionar outra possibilidade interpretativa do episódio: o animal por ser domado são os impulsos sexuais incestuosos do Primo. O Primo, porém, tira a lição errada do acontecido, pois conclui que necessita de uma estratégia astuciosa para conquistar a prima, da mesma forma que o moleque Nicanor fizera com a égua que domara: “E, nisto, fiquei sabendo, de repente, que tinha elaborado um plano... Tenho necessidade urgente de valorizar-me. Ah, Maria Irma!” (p. 213). Por isso, procura enciumar a prima e empreende a viagem para a fazenda das Tranqueiras, onde reside a Alda, “que está muito bonita, dizem, e que, em outros tempos, tal qual Maria Irma, foi minha namorada de brinquedo.” (p. 213). Do resultado desse desajeitado plano já falamos acima: tio Emílio aproveitou a viagem do sobrinho para efeito político e, quanto à conquista da prima, o resultado foi nulo. As interpretações que o narrador de Minha gente vai dando às experiências que está vivendo demonstram que ele tem consciência muito limitada do que lhe está sucedendo. A narrativa supre-nos de dados para interpretar os fatos narrados de maneira muito diferente do modo que o Primo o faz. 
O Primo corre o risco permanente da prática do incesto, e Bento Porfírio sucumbe a ele. Esse risco é metaforizado pelas várias passagens do conto até aqui analisadas e em outras que adiante trataremos. Uma dessas passagens relata a viagem do Primo para a fazenda das Tranqueiras. A prima, ardilosamente, chama-o de volta (p. 219) para apresentá-lo a Armanda, noiva de Ramiro. O Primo, como sempre, não entende corretamente a manobra da prima e se rejubila com o convite para o retorno, entendendo que a prima o chamava, tomada pela saudade: "Pulei do banco, e gritei de alegria. Os novilhos, que enchiam o curral esperando a marcação, pareceram-me um exército, aguardando ordens minhas para arremeterem em fileiras.” (p. 219). A ordenação dos novilhos serve aqui como um sinal, não captado pelo Primo, de que a ordem natural está para ser instalada com a eliminação da desordem gerada no incesto (a ordenação do gado como metáfora da substituição da desordem do estado de natureza pela ordem foi mostrada em $O$ burrinho pedrês).

Ainda nas Três Barras e antes do recebimento da carta de tio Emílio, o Primo ouve de um velho papagaio uma cantiga em cuja letra está a previsão de que ele não terá o amor de Maria Irma, a Mariquinha da cantiga. Essa passagem parece ter um significado de interesse, pois a ilustração de Poty que se situa no final o texto do conto, na página 233 da 5ª edição, mostra justamente a ave e um balão dentro de um círculo. Mas o papagaio mais se assemelha a uma peça de madeira do que a um bicho vivo, com um rabo saindo do círculo cuja forma estranha não pudemos

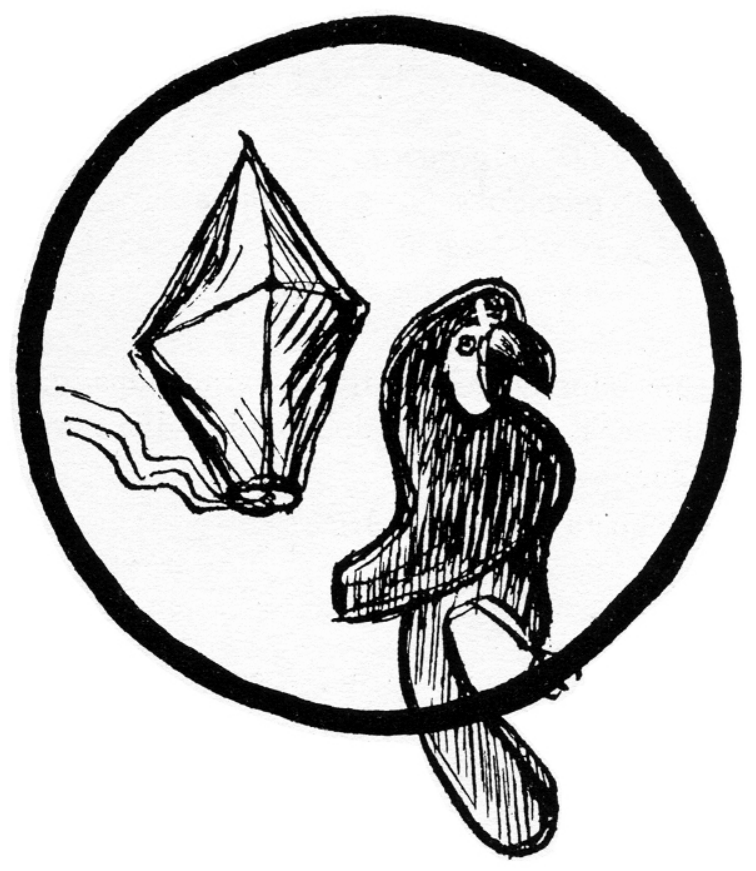
identificar qual seja:

E eu pensava, sempre em Maria Irma.

Mas o único acontecimento mesmo acabrunhante foi produzido por um papagaio, geral e caduco, já revertido ao silêncio, que cochilava em seu poleiro, mas que, um dia, lembrando-se de outrora, entortou a cabeça, me olhou com um olho, e, esganiçado, cantou:

"Cadê "Mariquinha?

Foi passiá...

Entrou no balão 
Virou fogo do á!...”

- Gagá idiota! Deixa de cantar bobagens!

- Fogo... Fogo!... Prrrr... Fogo! Fogo do á!...

Mas, aí, a negrinha Carmelinda chegou e explicou:

- É por causa que essa-uma é a cantiga que a gente ensina p'ra todos os papagaios... E é a derradeira que eles esquecem, quando já estão velhinhos...(p. 219).

A ordem natural é estabelecida quando Maria Irma apresenta Armanda ao Primo: do mesmo modo que o nome Irma está dentro do de Ramiro, o Primo parece estar à espera de Armanda há já muito tempo:

- Você gosta de Maria Irma?

- Não...

- De quem?

- De você... Sempre gostei. Sempre! Antes de saber que você existia...

- É engraçado...

- É verdade.

- Não... Não é isso. . .

Armanda jogou fora o botão de bogari, e entrecruzou os dedos. E disse:

- É com você que eu vou casar.

- Comigo?!...(p.221- 222).

A narrativa de Minha gente começa com a chegada do protagonista à estação de trem do arraial. Seu nome, profissão ou qualquer característica física não serão mencionados na obra e tampouco sabemos o motivo de sua vinda ao local em época de eleições. Santana aguarda-o na estação de trem e também ali se encontra José Malvino, para conduzi-lo a cavalo à fazenda de tio Emílio.

Os três cavaleiros empreendem então a viagem de quatro horas, durante a qual vão palestrando sobre vários temas; os aspectos tratados até aqui são completados e reforçados pelos acontecimentos dessa viagem, ou melhor, a viagem serve como uma visão geral das idéias contidas na obra. Alguns desses acontecimentos já foram analisados e de outros trataremos a seguir.

Parte do percurso dos três viajantes é em aclive: "Cavalgamos. Subimos. Subir mais. Agora, um lançante contínuo, serra avante em lombo longo, escalando o espigão. E, pronto, o mundo ficou ainda mais claro: a subida tinha terminado, e estávamos em notáveis altitudes.” (p. 179). Nesse topo ocorre a passagem com os vôos do gaviãopinhé, do urubu solitário e do bando de urubus:

Em vôo torto, abrindo sol e jogando sol para os lados, passou um gavião-pinhé.

Em dois minutos, com poucos golpes de asas, sobrecruzou a crista da cordilheira, mudando 
de bacia: viera de rapinar no campo das águas que buscam o ocidente, e agora se afundava nas matas marginais dos arroios que rojam para leste: Estava tosando ar alto, mas nós olhávamos o vôo como quem se inclina para espiar um peixe num aquário.

Depois, o urubu. Pairou, orbitando giros amplos. Muito tempo. Mesmo para os seus olhos de alcance, era difícil localizar o alimento. Fechou, pouco a pouco, os círculos. Descaiu, de repente, para um saco em meia- lua, entre duas vértebras da serra. Adernou. E soçobrou no socavão.

E muitos outros urubus, vindos de todas as direções, convergiam para aquele buraco. De vez em quando, alguma coisa devia ir mal, lá por baixo, porque eles subiam do cafundó, revoluteando, que nem, em tarde de queimada, restos de folhas num redemoinho de vento. Deslocavam-se, alternando de planos, avançando uns e crescendo, enquanto outros fugiam fundo, em grãos minúsculos. Até que, de novo, desfaziam os pontos de dominó, e, a um tempo, se abatiam para o brechão.

- Carniça de algum bicho do mato... raposa... - comentou José Malvino.

Não gostei do prosaísmo. Dei rédea ao cavalo, e proferi:

- Melhor um pássaro voando do que dois na mão!... Eis a versão do provérbio, para uso dos fortes, dos capazes de ideal...

- É a versão dos otários, também. (p. 180-1)

O gavião, como a águia, simboliza os poderes de sol; no Egito era a ave do deus Hórus, portanto um emblema solar; o que sugere o recurso à religião egípcia como base para interpretar a hierofania do sol é a descrição física de Maria Irma, que a faz assemelhar-se às pinturas e talhas egípcias, com "mãos morenas, um pouquinho longas (...) braços bronzeados...” (p. 204) e "cintura fina, abrangível; corpo triangular de princesinha egípcia... Mas a sua maior beleza está nos olhos: olhos grandes, pretíssimos, de fenda ampla e um tanto oblíqua, electromagnéticos, rasgados quasemente até às têmporas, um infinitesimalzinho irregulares; lindos! Tão lindos, que só podem ser os tais olhos Ásia-na-América” (p. 189). Como veremos em São Marcos, o Egito na Bíblia simboliza a pátria da sensualidade e do amor sensível e feminino.

O gavião, irradiando luz, voa majestoso com pouco esforço em campos drenados para efetuar sua rapina, deslizante como um peixe em um aquário. Em clara oposição ao gavião estão aos urubus, que se lançam sobre a carniça de raposa morta no fundo de uma grande cova. Entre esses dois extremos está o urubu solitário, que se modela pelo gavião, mas se comporta como o bando.

O caráter alegórico da passagem pode estar relacionado ao diálogo imediatamente precedente da página 180 - já transcrito acima - entre Santana e o Primo, no qual o primeiro pensa no Brasil e o outro restringe sua visão a Minas Gerais. Se supusermos que Minha gente trata predominantemente de política e amor, podemos 
arriscar uma interpretação dessa passagem: a de que o gavião representa o ideário político do estadista, mais amplo e voltado para o interesse público, enquanto o bando dos urubus é a representação figurada dos políticos que se lançam como aves carniceiras sobre o bem público, em benefício próprio - idéia que soa bem ajustada às noções de Oliveira Vianna e de Sérgio Buarque de Holanda sobre a política brasileira a que nos referimos em $O$ burrinho pedrês. O urubu solitário é figura daquele que, a despeito de reconhecer a nobreza da prática do bem comum, pode não resistir ao impulso de se aproveitar do patrimônio público para benefício privado. Essa pode ser a razão pela qual o Primo desgosta da vulgaridade do comentário de José Malvino, pois entende que o exercício da política restrita ao seu Estado natal - e este como centro do mundo - e a partir dele (como a idealizara ao falar que "Minas principia de dentro para fora e do céu para o chão...”) é associada a urubus devorando carniça.

As formas de entender o exercício do poder, como estamos interpretando neste episódio, podem ser buscadas em Aristóteles, na Ética a Nicômano (v. A volta do marido pródigo). Mas é possível enriquecer ainda mais a interpretação da mesma passagem admitindo-a como figuração dos três tipos de vida dos seres humanos, sempre segundo Aristóteles; de acordo com essa interpretação, o vôo do gavião seria a imagem da atitude contemplativa, que faz que a ave resplandeça, "abrindo sol e jogando sol para os lados”, aproximando-a do sol, representação da divindade em várias religiões. O bando de urubus figuraria o extremo da vida instintiva, onde se encontra o homem em estado de natureza, com todas as características já definidas anteriormente (v. O burrinho pedrês, "no redemoinho de vento" mora o diabo, a desordem). E, finalmente, o urubu solitário, figura do homem de vida política - conforme conceituada pelo mesmo Aristóteles em Ética a Nicômano -, pode aproximar-se do estado contemplativo ou afundar-se na vida instintiva, dependendo de sua escolha:

A julgar pela vida que os homens levam em geral, a maioria deles, e os homens do tipo mais vulgar, parecem (não sem um certo fundamento) identificar o bem e a felicidade com o prazer, e por isso amam a vida dos gozos. Pode-se dizer, com efeito, que existem três tipos principais de vida: a que acabamos de mencionar, a vida política e a contemplativa. A grande maioria dos homens se mostram em tudo iguais a escravos, preferindo uma vida bestial, mas encontram certa justificativa para pensar assim no fato de muitas pessoas partilharem os gostos de Sardanaplo. (ARISTÓTELES, 1973, p. 251-52; 1095b)

Mas a definição destes três tipos de seres humanos pode ser estendida à definição das três formas de amor sobre as quais nos referimos brevemente quando 
analisamos Sarapalha e cuja presença na obra de Guimarães Rosa foi mostrada por Roncari em sua análise de São Marcos. De momento, interessa-nos identificar o bando de urubus famintos à figura do amor instintivo, exclusivamente carnal, e o urubu solitário à figura do amor humano, criado e cultivado por meio da sedução. O gaviãopinhé resplandecente seria a figura do amor contemplativo. De fato, é toda iluminada pelo sol que Dante, cujo sentimento por Beatriz é paradigma do amor contemplativo, vê sua amada no Canto I do Paraíso. No mesmo canto, é estabelecida a relação entre o sol e a águia (que aqui se identifica ao gavião), da qual falamos acima:

Dali nascia a luz; daqui viera

A noite; e um hemisfério branquejava

Em quanto ao outro a treva enegrecera,

Eis vi que à esquerda Beatriz fitava

Olhos no sol; jamais águia afrontara

Tanto desse astro o lume, que ofuscava. (ALIGHIERI, Paraíso, Canto I, 43-48). ${ }^{24}$

Por tudo o que dissemos, podemos sintetizar as interpretações possíveis da passagem e concluir que ela é uma alegoria das idéias aristotélicas das três categorias de seres humanos. Essas três categorias de modos de pensar e de agir estão associadas diretamente aos níveis topográficos nos quais se realizam os vôos das aves. É por essa razão que a visão que as personagens têm em sua viagem vai dando diversos pontos de vista: a visão do topo para o alto trata de temas amplos e gerais, e a do topo para baixo mostra a realidade local, as relações políticas, sociais, amorosas; os três poços, que o Primo e Bento Porfírio encontram no caminho para as duas pescarias, têm função similar aos vôos do gavião e dos urubus, e os níveis topográficos dos poços estão também relacionados às três categorias de indivíduos dos quais fala Aristóteles. Essa associação de amplitude de pontos de vista a níveis topográficos é, além de fisicamente compreensível, amplamente confirmada pela simbologia da montanha, porque é nesta que céu e terra se encontram e, por essa razão, quase todas as religiões possuem sua montanha sagrada central e suas montanhas secundárias (voltaremos a esse assunto na análise de A hora e vez de Augusto Matraga). E é por isso que a chegada na fazenda é

$24 \quad$ Fatto avea di là mane e di qua sera

tal foce, e quasi tutto era là bianco

quello emisperio, e l'altra parte nera,

quando Beatrice in sul sinistro fianco

vidi rivolta e riguardar nel sole:

aquila sì non li s’affisse unquanco. (ALIGHIERI, Paraíso, Canto I, 43 - 48) 
descida íngreme, o ambiente é escuro e está em contraposição ao araxá, o "lugar donde se avista primeiro o sol” (MARTINS, 2001, p. 40): é a chegada ao mundo físico dos homens, dos instintos, do estado de natureza, das paixões humanas apresentadas sob várias formas e é onde se desenvolverá a trama (acima falamos do simbolismo da escuridão). O local é o Saco-do-Sumidouro, nome que soa mais terrificante do que "saco em meia-lua”, o buraco dos urubus:

Uma descida, íngreme e pedrosa. Funda. Mas, lá em cima, ainda está claro, porque lá em cima é o araxá.

Descemos ainda. Vadeamos um regato raso. De sombra em sombra, a estrada anoitece, entrando debaixo do mato, porque as árvores tecem teto. Os animais querem andar mais ligeiro. E é a derradeira descida, pois a casa da fazenda fica num umbigo de taça. (p. 185).

O último parágrafo, descrevendo um lugar escuro que se afunila, sugere uma referência ao Canto V, versos 1 a 3 da Divina Comédia, da descida ao inferno:

Desci desta arte ao círculo segundo, Que o espaço menos largo compreendia, Onde o pungir da dor é mais profundo. (ALIGHIERI, Inferno, Canto V, $1-3)^{25}$

Voltemos à viagem dos três homens. Após percorrerem um trecho em aclive, eles sobem novamente, guiados por um sol resplandecente que se assemelha a um brasão medieval. A paisagem é poeticamente descrita pelo narrador. Então os viajantes dão com um cavaleiro, que o narrador assimila a São Jorge:

E continuamos, seguindo o sol, quase em tramonto - um sol de recorte nítido, não ofuscante. Refrescou. E a estrada subia e descia, mas, como as descidas eram muito menores, nós subíamos sempre. A tarde tinha recuado. Um resto de cirros, no alto, em alvas trabéculas rarefeitas; um empilhado de faixas, tangerina e rosa, no poente; no mais, o céu era lisa campânula de blau.

De brusco, no tope do outeiro que íamos galgando, surgiu um cavaleiro, caído do sol. Ficou parado, um momento, sopesando a vara longa. E era bem um São Jorge, enrolado em claridade amarela e coroado de um resplendor carmesim. (p. 182)

A figura de São Jorge é sempre associada ao dragão, e a simbologia deste último é vasta e contraditória, como grande parte dos símbolos. Mas, como neste caso está presente a figura do Santo Guerreiro, podemos interpretar o dragão como símbolo cristão. Nessa conotação, o dragão, como figura do mal, é derrotado por São Jorge e São

\footnotetext{
${ }^{25}$ Così discesi del cerchio primaio giù nel secondo, che men loco cinghia, e tanto più dolor, che punge a guaio. (ALIGHIERI, Inferno, Canto V, 1 - 3)
} 
Miguel e, às vezes, pelo próprio Cristo - que ocasionalmente é representado calcando um dragão. Mas, como a religiosidade não é o tema central do conto, cabe atribuir outro sentido à passagem. Para tanto, recorreremos ao conceito de civilização expresso em $O$ mal-estar da civilização, de Freud. Segundo James Strachey, que comenta a edição das obras completas do autor austríaco, o tema principal do livro é “o antagonismo irremediável entre as exigências do instinto e as restrições da civilização” (FREUD, 1974, vol 21, p. 76).

Freud considera três fatores que desempenham papel no processo de civilização, sendo o primeiro a formação de traços de caráter; assim ele discorre sobre os outros dois fatores:

A sublimação do instinto constitui um aspecto particularmente evidente do desenvolvimento cultural; é ela que torna possível às atividades psíquicas superiores, científicas, artísticas ou ideológicas, o desempenho de um papel tão importante na vida civilizada. Se nos rendêssemos a uma primeira impressão, diríamos que a sublimação constitui uma vicissitude que foi imposta aos instintos de forma total pela civilização. Seria prudente refletir um pouco mais sobre isso. Em terceiro lugar, finalmente - e isso parece o mais importante de tudo -, é impossível desprezar o ponto até o qual a civilização é construída sobre uma renúncia ao instinto, o quanto ela pressupõe exatamente a nãosatisfação (pela opressão, repressão, ou algum outro meio?) de instintos poderosos. Essa "frustração cultural" domina o grande campo dos relacionamentos sociais entre os seres humanos. Como já sabemos, é a causa da hostilidade contra a qual todas as civilizações têm de lutar. (FREUD, 1974, vol 21, p. 118).

Por outro lado, quando acima escrevemos sobre o incesto, vimos que, para Freud e Clastres, a relação incestuosa está na base da desagregação social, por provocar o isolamento do grupo familiar. Portanto, a civilização exige do indivíduo a renúncia ao incesto e a sublimação dos instintos, tanto o de morte como o sexual, sendo a renúncia ao incesto uma forma de disciplinar o instinto sexual.

A repressão ao instinto de morte se faz pelo contrato social. O contrato se materializa na criação do Estado que detém o monopólio da violência legítima como forma de repressão da violência individual. A sociedade primitiva é a sociedade sem Estado; portanto, a civilização só existe com a condição de existir Estado, conceito weberiano endossado por Clastres (CLASTRES, 2004, p. 149), que parece presente em Sagarana. No conto, a tentativa de formação do Estado está contida no processo eleitoral em andamento, do qual sai vencedor tio Emílio, e a renúncia ao incesto pelo Primo é controlada por Maria Irma. Mas, quando tratamos do segundo poço por onde passam o Primo e Bento Porfírio a caminho da pescaria, dissemos que o fato de o jacaré 
que ali está escondido poder ou não existir indica a possibilidade de escolha que tem o homem de retroceder ou não ao estado de natureza. Se lembrarmos que a simbologia do jacaré é identificada à da serpente e à do dragão, teremos condições de interpretar a figura de São Jorge em sua luta contra o dragão como a alegoria da luta da humanidade contra o estado de natureza, ou seja, contra o predomínio dos instintos que tendem a tornar a civilização inviável. Assim entendida, a representação da figura de São Jorge é uma antecipação da do jacaré no segundo poço.

Se, para efeito didático, desmembrarmos a alegoria contida nesse trecho, poderemos dizer que, no aspecto político e social do conto, o dragão representaria o mal para a sociedade, mal que deve ser eliminado; portanto, a luta do santo contra o monstro que a ameaça seria a luta da civilização contra o instinto de agressividade que tende a desagregá-la. Mas o conto também trata de amor, e o embate simbolizaria a luta do homem na repressão de seus instintos sexuais; do ponto de vista cristão, a figura do santo guerreiro parece inspirar esses instintos, fonte do mal que pode levar o homem ao pecado e à perdição. Desse modo, o santo é uma figura alegórica que, no campo social e político, representa a luta permanente entre a civilização e a selvageria e, no campo afetivo, a luta contra o amor instintivo e a desordem gerada pelo incesto. Portanto, no âmbito mais amplo, o embate do santo é o embate da humanidade pela civilização e contra o instinto desenfreado e liberado que provoca o retorno ao estado de selvageria. E a civilização só se torna viável pela repressão dos instintos e pela recusa do incesto.

As táticas empregadas por Maria Irma para conquistar o noivo de Armanda são parte de um jogo complicado, no qual ela entra com astúcia, esperteza, retórica e capacidade de manipular os sentimentos do Primo, rearranjando, de acordo com seus desígnios, as relações afetivas entre as quatro personagens - Ramiro, Armanda, o Primo e ela própria. Por outro lado, no campo político, desenvolve-se um jogo igualmente complicado para a conquista de votos a favor de tio Emílio, no qual entram acordos e arranjos amigáveis, compadrio e muitos outros, jogo no qual as esferas pública e privada mal se diferenciam. Essas manobras nos campos do poder e do amor, que os seres humanos executam nos campos pessoal e social ao longo da história da humanidade, são metaforizadas por meio de um jogo de xadrez que não se conclui entre Santana e o Primo - assim como não se concluiu a partida que jogaram na estada anterior do Primo na fazenda. Que o jogo de xadrez é, no conto, relacionado com o amor, podemos observar nas passagens abaixo: 
Não importa, no começo é assim mesmo - pensei. Devo mostrar-me caído, enamorado. Ceder terreno, para depois recuperá-lo. É boa tática... “Um gambito do peão da Dama”, como Santana diria... (p. 210)

Tudo saiu pior do que o pior que eu esperava. Maria Irma despreza a minha submissão. Tenho de jogar um “gambito do peão da Dama, recusado...” (p. 210).

- Deixemos esta conversa tola, Maria Irma...

- Deixemos. Até logo. Bom passeio!

Mordi os beiços e não gemi. Santana teria apenas classificado: partida empatada, por xeque perpétuo...(p. 214)

Na ilustração da página inicial do conto, a 181, da $5^{a}$ edição de Sagarana, vemos parte de um tabuleiro de xadrez inscrita em um círculo. Quatro casas brancas desse tabuleiro são ocupadas por rostos de duas figuras masculinas na horizontal e duas femininas na vertical. Pode-se supor que os quatro rostos sejam das quatro personagens envolvidas na trama amorosa. Neste caso, o amor envolvendo diretamente as quatro personagens seria

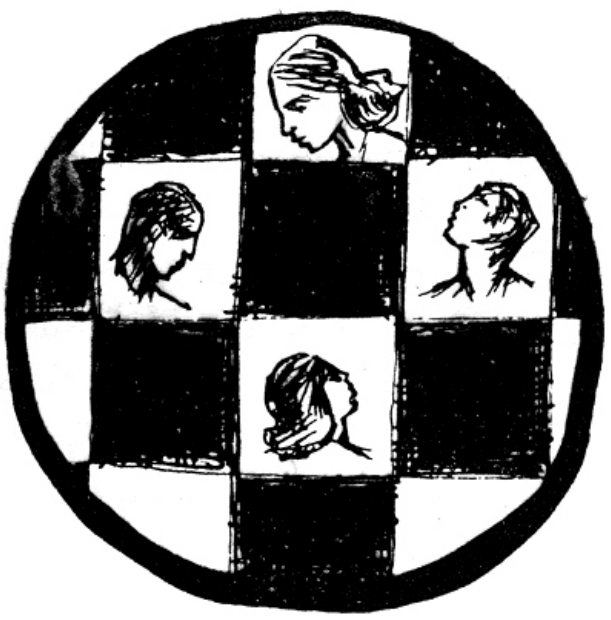
figurado no estratégico jogo de xadrez. O jogo de xadrez, ligado à estratégia guerreira, permite assimilar a uma guerra o jogo em que as personagens do conto se empenham, que exige dos contendores alta capacidade de formulação de estratégias capazes de levar à vitória, como ocorre com tio Emílio nas eleições e com Maria Irma no campo do amor. E, por causa desta última, saem beneficiados também o Primo, Armanda e Ramiro. O jogo se desenrola como um combate entre peças negras e peças brancas, entre sombra e luz, em suma, entre pólos antagônicos, remetendo aos antagonismos vividos pelo Primo em suas relações afetivas, mas que, no final das contas, são, como vimos, representações diretas do antagonismo entre civilização e selvageria.

Em vários contos de Sagarana há referências a jogos, principalmente o de cartas, que requerem astúcia e sorte, mais do que inteligência, e em nenhum deles se pratica o “nobre jogo” de xadrez, como diz o Primo. Por exemplo, Oscar, filho do major Anacleto de A volta do marido pródigo, entende o jogo amoroso como um jogo de truque, em sua desajeitada tentativa de seduzir a mulher de Lalino: "Seu Oscar era jogador de truque e sabia que “a primeira é a que vai à missa!”. Assim, achou que estava na hora de não perder a vaza” (p. 107). Mas, em Minha gente, no jogo da política 
e do amor é aplicada a inteligência estratégica requerida pelo jogo de xadrez mais do que a esperteza e a falta de escrúpulos que entram no jogo de $A$ volta do marido pródigo; e, ao leitor, o entrelaçamento entre os diversos aspectos apresentados simultaneamente no conto parece requerer as habilidades de enxadrista para ser interpretado.

Esperamos ter conseguido mostrar que o social determina o conteúdo tanto de $A$ volta do marido pródigo como o de Minha gente, e que, deste último conto, é possível inferir questões conceituais sobre a criação de uma sociedade civilizada. Essas questões são cuidadosamente desenvolvidas no âmbito do público e do privado por meio da narrativa dos acontecimentos nos dois campos em que atua o Primo narrador do conto. Duas histórias de amor se desenrolam, envolvendo primos: a de Bento Porfírio com deLurdes e a do Primo com Maria Irma; a primeira se realiza no campo sexual e termina em tragédia, enquanto a segunda só não é levada a termo, como deseja o Primo, graças à habilidade da prima. Ao impedir a união de familiares, Maria Irma afasta o risco imediato da degeneração genética e, metaforicamente, o do isolamento social, que levaria ao retorno ao estado selvagem, no qual a sociedade civilizada deixa de existir. O risco de retorno à desordem, ao estado de natureza é abundantemente mostrado em várias passagens alegóricas e metafóricas do conto, como vimos.

O Primo tudo ignora, e sua inconsciência não se limita ao jogo do amor e à sua ingênua relação com a prima, mas se estende à política, da qual pouco compreende, pois fica à margem do processo eleitoral que está em pleno andamento, e a sua atitude de abandonar o Saco-do-Sumidouro às vésperas das eleições é apropriadamente entendida pelo tio como ato de ingratidão. A inconsciência do Primo na política e no amor, portanto no público e no privado, é elemento-chave para a compreensão do aspecto social que dá sentido ao conto. O casamento de Maria Irma com Ramiro sanciona a união de duas famílias rurais de prestígio, servindo, portanto, de suporte ao exercício continuado do poder.

Como se pode observar nas interpretações dos contos feitas até aqui, utilizamos com freqüência trechos de Sezão para esclarecer alguns aspectos de Sagarana, porque, via de regra, em Sezão, Guimarães Rosa foi mais explícito e claro do que em Sagarana. Como este segundo livro é o nosso objeto de estudo, esse procedimento tem sido e será adotado com cautela e apenas para confirmar e esclarecer algum aspecto que esteja 
presente em Sagarana. Este cuidado é essencial, pois o recurso a Sezão não deixa de ser arriscado: entre os vinte e nove e os trinta e oito anos de idade um homem pode mudar substancialmente suas crenças sobre qualquer assunto, principalmente se for motivado para o estudo e o aprendizado e se for provido de espírito arguto e inquisitivo. Não é, portanto, difícil que Guimarães Rosa tenha revisado algumas das idéias presentes em um ou mais contos de Sezão e tenha modificado a obra com base na sua nova visão, em decorrência dos dramáticos acontecimentos que viveu e observou entre as datas de escrita das duas obras.

Alguns contos foram pouco alterados - Sarapalha, por exemplo -, ao passo que outros sofreram revisão profunda na escrita, embora ainda sustentando as mesmas idéias gerais expostas em Sezão; é o que ocorre, por exemplo, com Conversa de bois. No caso de Minha gente, uma parte razoável do texto literário foi conservada de um livro para o outro, mas, diferentemente do que ocorre em Sagarana, em Minha gente de Sezão o objetivo de Maria Irma é conquistar o Primo, e é o que realmente acontece. Esse fato poderia anular tudo o que expusemos acima sobre a questão do incesto. No entanto, a diferença entre os dois textos pode ser interpretada de duas maneiras. A primeira é que as idéias de Rosa sobre o o assunto se tenham sedimentado depois de Sezão e antes de Sagarana; contudo, o caso de amor entre Bento Porfírio e a prima já existia em Sezão com o mesmo desfecho trágico; este fato suscita a segunda interpretação: a de que o incesto é visto em Sezão sob a mesma perspectiva com que é visto em Sagarana, mas, enquanto em Sagarana o risco de o Primo perder-se é evitado pela prima, em Sezão o risco permanece latente e é evidenciado no episódio de Bento Porfírio. Acreditamos ser essa a razão pela qual o Primo e Maria Irma não se casam em Sezão: o conto se encerra quando ela confessa sua paixão. 


\section{SÃO MARCOS}

A análise de São Marcos da qual nos ocuparemos a seguir deriva, em sua essência, da análise feita por Roncari em O Brasil de Rosa, mas com algumas diferenças significativas, decorrentes da própria abertura da obra, de sua complexidade e da amplitude de temas abordados.

São Marcos apresenta alguns aspectos que o distinguem dos demais contos de Sagarana: é a mais apurada abordagem da religião brasileira; é a melhor exposição sobre o poder transformador da palavra; é o melhor discurso sobre o amor, a que Roncari deu o nome de "teoria dos três amores"; é a mais completo discurso sobre as conexões entre cultura universal e cultura popular, discurso que inclui, além da religião, a posição de Guimarães Rosa e dos modernistas sobre tais conexões; além disso, enseja reflexões sobre vários temas filosóficos, como contemplação, razão, intuição, instinto. Essa interpenetração de temas em São Marcos levanta de imediato a suspeita de que eles têm algum parentesco entre si e de que, no conjunto, devem dar sentido à obra em sua totalidade. A existência de tal sentido geral é sugerida pelo fato de Guimarães Rosa ter agrupado em um único conto temas aparentemente tão diversos que poderiam ser expostos separadamente e acomodados de maneira mais justa nos outros contos de Sagarana. Assim, por exemplo, pareceria mais razoável expor uma teoria sobre o amor em contos como Sarapalha e Minha gente ou um discurso sobre o sincretismo brasileiro em Corpo fechado ou em A hora e vez de Augusto Matraga. É nosso propósito demonstrar que esses temas de São Marcos estão intimamente inter-relacionados e vinculados à questão que apaixonou a intelectualidade brasileira na época da elaboração de Sezão e do lançamento de Sagarana: a discussão em torno do espírito nacional.

Para maior clareza de exposição desta análise, esses aspectos serão tratados separadamente, com alguns vaivéns inevitáveis, decorrentes do próprio caráter imbricado com que eles se apresentam na narrativa.

Numa resenha de 1947, Manoel Cerqueira Leite discute a relação do autor com o narrador em Sagarana e afirma que, em São Marcos, “contador e autor vão juntos, na narrativa que oscila, ora para um, ora para outro” (Jornal de São Paulo, 10 fev. 1947 [IEB, CGR, PR1, p.45], apud RONCARI, 2004, p. 112). São Marcos é narrado na primeira pessoa, e o narrador faz referência à sua homonímia com o pássaro joão-debarro, ao “meu xará joão-de-barro” (p. 228), além de associar seu estado contemplativo 
ao do pássaro joão-grande: "E lá está o joão-grande, contemplativo, ao modo em que eu aqui estou” (p. 246); mas também se chama José: “nesta estória, eu também me chamarei José” (p. 228). Esses aspectos sugerem que se procure determinar a significância das relações entre autor, narrador e personagem na interpretação da obra.

Seguramente, Guimarães Rosa está longe da estética em que parecia normal e até desejável que o narrador, assumindo o lugar do autor, a qualquer momento introduzisse na narrativa comentários e opiniões pessoais, argumentando, pontificando, acusando, defendendo pontos de vista - como Balzac e Victor Hugo. Também longe está da ilusão do realismo e do naturalismo, quando se preconizava, como Flaubert, que o romancista deveria tratar a alma humana com a mesma imparcialidade com que os cientistas estudam a matéria. Wayne C. Booth em A Retórica da ficção, afirma que nenhum autor pode conseguir a objetividade - e seus sintomas, como neutralidade, imparcialidade e impassibilidade:

Enquanto escreve, o autor não cria, simplesmente, um "homem em geral", impessoal, ideal, mas sim uma versão implícita de "si próprio", que é diferente dos autores implícitos que encontramos nas obras de outros homens. (...) Quer adotemos para este autor implícito a referência "escriba oficial”, ou o "alter ego" do autor (...) é claro que aquilo de que o leitor se apercebe nesta presença são os efeitos mais importantes do autor. Por impessoal que ele tente ser, o leitor construirá, inevitavelmente, uma imagem do escriba oficial que escreve desta maneira e, claro, esse escriba oficial nunca será neutral em relação a todos os valores. A nossa reação aos seus vários compromissos, secretos ou a descoberto. ajudará a determinar a nossa resposta à obra. (BOOTH, 1980, p. 88-9)

Mesmo em histórias contadas na primeira pessoa, sempre o autor implícito se apresentará com maior ou menor nitidez; de fato, em Minha gente e Corpo fechado, narrados na primeira pessoa, é evidente o distanciamento entre narrador e autor implícito. Booth afirma que "Dizer que uma história é contada na primeira ou terceira pessoa nada nos diz de importante, a menos que sejamos mais precisos e descrevamos o modo como qualidades particulares de cada narrador se relacionam com efeitos específicos. (...) As diferenças talvez mais importantes do efeito narrativo dependem do facto de o narrador ser, ou não, dramatizado individualmente e de as suas crenças e características serem ou não, partilhadas pelo autor.” (BOOTH, 1980, p. 166-7). Booth completa: “Em qualquer experiência de leitura, há um diálogo implícito entre autor, narrador, os outros personagens e o leitor. Cada um destes quatro pode ir, em relação a cada um dos outros, desde identificação a completa oposição, sobre qualquer eixo de valores morais, intelectuais, estéticos ou mesmo físicos.” (BOOTH, 1980, p. 166-7). 
Em São Marcos ocorre identificação entre narrador e personagem; já a relação entre narrador e autor implícito é flutuante: identificação de valores intelectuais e estéticos - e, nesse caso, o narrador se chama João - e conflito de valores morais, quando o narrador se chamará José. Podemos intuir que é José quem se encaminha para o mato das Três Águas e que, de passagem, insulta João Mangolô, mostrando - ou pelo menos simulando para desafiar o interlocutor - virulento racismo; e é José quem fica cego, vítima do feitiço do catimbozeiro. Mas é João que se identifica com o autor implícito, que, em estado contemplativo, frui a beleza da natureza e vai mostrando ao leitor as noções sobre religião, amor, etc., encerradas no texto e que tentaremos resgatar nesta análise.

Como em São Marcos personagem, autor implícito e narrador - estejam eles em certo momento da história se aproximando ou não - têm a mesma formação cultural e intelectual, cria-se uma nítida e didática separação entre a cultura do personagemnarrador e a dos rústicos habitantes do lugar. Mas, como quase sempre acontece em casos similares, cada uma dessas três entidades atua em diferentes níveis e enfrentam questões diferentes dentro da obra: o protagonista vive algumas experiências em seu convívio com os habitantes do Calango-Frito e sofre as conseqüências da concordância ou da discordância de sua forma de pensar e das atitudes que toma em relação às crenças dos habitantes locais; dentre essas experiências, a religiosa será significativa, mas não será a única. O problema do narrador é o da escolha de qual posição narrar, de como expressar a maneira de pensar e de agir dos rústicos habitantes do Calango-Frito e do protagonista, um homem culto da cidade. Já o problema do autor implícito é de ordem conceitual, na medida em que envolve questões relativas à sua visão estética e social; estética, porque trata de escolhas formais e de estabelecimento de relações entre a cultura popular e as tendências culturais e literárias dominantes na época da escrita do conto; e social, porque estabelece um conjunto de dados que contribuem para a representação do Brasil que, de acordo com nossa interpretação, está contida em Sagarana.

Embora em outros contos o sincretismo religioso tenha presença marcante, como em Corpo fechado e A hora e vez de Augusto Matraga, é em São Marcos que o autor caracteriza de forma mais apropriada a complexa descrição da religiosidade nacional.

A religião em Sagarana assume duas formas distintas. A primeira engloba as manifestações religiosas que, no texto literário, se apresentam com maior ou menor 
evidência e são captadas apenas pelo leitor, não estando conscientemente acessíveis para as personagens: são referências às religiões cristãs e a outras do mundo antigo e moderno, bem como às expressões do sagrado conhecidas pelo nome genérico de religiões arcaicas: mitologias e hierofanias de sol, lua e outras. A segunda enfeixa as formas religiosas conscientemente perceptíveis e praticadas pelas personagens (por exemplo, o catolicismo de Nhô Augusto e do casal de pretos de A hora e vez de Augusto Matraga) ou outras formas religiosas que nasceram e se desenvolveram a partir da combinação de crenças e costumes dos vários povos indígenas, africanos e europeus que participaram da formação da nossa cultura, crenças que foram chamadas de "religiões populares” por Eneida D. Gaspar (GASPAR, 2004); o feiticeiro Mangalô, deste São Marcos, ou o curandeiro Antônio das Pedras, que fecha o corpo de Manuel Fulô, em Corpo fechado, são praticantes de religiões populares.

Nas duas formas de representação da religião em Sagarana encontramos evidências de amplo sincretismo. A maior parte das personagens se diz católica, mas, de fato, mostra-se adepta de várias crenças, como os moradores do Calango-Frito. Reproduz-se desse modo o que diz Riobaldo a respeito de sua própria crença "Eu cá, não perco ocasião de religião. Aproveito de todas. Bebo água de todo rio... Uma só, para mim é pouca, talvez não me chegue. Rezo cristão, católico, embrenho a certo; e aceito as preces de compadre meu Quelemém, doutrina dele, de Cardéque. Mas, quando posso, vou no Mindubim, onde um Matias é crente, metodista” (ROSA, 1956, p. 17). Ao se perguntar se o indivíduo brasileiro é católico, Mário de Andrade responde que "isso me parece duvidoso” e que, “como generalidade marcante se reconheça na psicologia do brasileiro a tendência religiosa, estou perfeitamente de acordo” (ANDRADE, M., 2002, p. 32); mais adiante afirma: “A religiosidade se desenvolveu. A catolicidade se corroeu por dentro, ficou apenas uma casquinha epidérmica” (ANDRADE, 2002, M., p. 33). Também Caio Prado Júnior em Formação do Brasil contemporâneo e Maria Sílvia de Carvalho Franco em seu ensaio A vontade santa sustentam pontos de vista semelhantes aos de Mário de Andrade; Sérgio Buarque de Holanda, no capítulo O homem cordial, de Raízes do Brasil, alude à pouca profundidade da religiosidade do brasileiro e estabelece relação direta entre religião e moral (HOLANDA, 1999, p. 115), voltando à já referida falta de coesão social e à fragilidade das nossas instituições, agora também no caso da religião - para cuja prática é exigida do fiel o cumprimento de um conjunto de atividades ligadas à liturgia e um comportamento social ajustado aos preceitos morais por ela estabelecidos. 
Em Sagarana, a presença de amplo repertório de religiões praticadas superficialmente pelas personagens confirma os pontos de vista desses autores. É comum o caso de personagens que ostentam um discurso católico e um comportamento nada cristão, como o Vinte-e-Um, de Duelo. Entretanto, em A hora e vez de Augusto Matraga encontramos um bom padre que confessa Nhô Augusto e o estimula a dedicarse à prática dos preceitos da regra beneditina, preceitos que serão rigorosamente seguidos pelo protagonista enquanto viver em Tombador. $\mathrm{O}$ fato de encontrarmos eventualmente uma personagem que cumpra à risca os mandamentos cristãos constitui a exceção que confirma a regra geral da pouca consistência religiosa. São amplos os limites da crença católica no conjunto da obra: num extremo, está Matraga; no outro, Cassiano Gomes, de Duelo, transgressor consciente dos mandamentos.

As crenças do narrador de Mangolô e da população do Calango-Frito integram o amplo quadro da religiosidade brasileira presente em Sagarana; o próprio nome do local, Calango-Frito, já sugere um estranho ritual de feitiçaria (a lagartixa é um dos ingredientes da poção preparada pelas bruxas de Macbeth em seus feitiços). A prática simultânea de várias crenças pelas personagens e as referências a formas variadas de religiosidade pelo narrador são casos particulares de uma relação mais ampla, entre o local e o universal, que dá sustentação à universalidade da obra, como dissemos na introdução deste trabalho. De modo geral, em Sagarana as manifestações culturais locais compreendem costumes, crenças, linguagem e artes folclóricas de origem africana ou indígena, enquanto as manifestações universais se mostram por referências ao acervo cultural externo, principalmente europeu e oriental - como religiões arcaicas ou mais recentes, mitologias e clássicos da literatura.

Não é mencionada no texto a crença religiosa do narrador antes de passar pela experiência da cegueira nele provocada pelo feitiço de João Mangalô. Os dois nomes do narrador, João e José, são os mais comuns do inventário onomástico brasileiro, de modo que ele pode ser considerado um brasileiro qualquer de nossa população e, por conviver em ambiente religioso fortemente diversificado, tende a atribuir caráter supersticioso às crenças alheias, mas não às suas. Assim, atribui às suas crenças pessoais uma legitimidade que nega às dos outros. Aurísio Manquitola fala da cultura e religiosidade do narrador: "O senhor, que é homem estinctado, de alta categoria e alta fé, não acredita em mão sem dedos, mas...” (p. 232); no entanto, antes mesmo dos acontecimentos que o levaram à cegueira, o protagonista já era supersticioso e adepto da numerologia, como fica patente nos primeiros três parágrafos do conto, em que apresenta uma lista de 
crendices (p. 224-5). Nesse aspecto ele participa da mentalidade dos moradores do local, ou melhor, é até mais supersticioso: "E só hoje é que realizo que eu era assim o pior-de-todos” (p. 225). A diferença entre os indivíduos do Calango-Frito e o narrador é que este não acredita na feitiçaria praticada por todos os habitantes do local, adultos e crianças: "Naquele tempo eu morava no Calango-Frito e não acreditava em feiticeiros”(p.224). Mais especificamente, ele não acredita que João Mangolô, respeitado e temido pela população, tenha qualquer poder sobrenatural. Em Sagarana não fica claro se o herói-narrador, depois de sua experiência, continuou cético ou passou a acreditar em feiticeiros; contudo, em Sezão, a conversão parece mais clara , e ele vai da incredulidade à credulidade: “Naquele tempo, não tendo eu ainda estudado as maravilhas da física hipermoderna, como poderia dar crédito a histórias de feiticeiros, com todo o brilho de suas façanhas de taumaturgos ilegais?!” (ROSA, J. G., 1937, p. 260); embora a ironia do texto ainda deixe no ar alguma dúvida sobre tal metamorfose, a menção da física quântica - que aceita o comportamento dual da radiação eletromagnética simultaneamente como onda e partícula - sugere a possibilidade de convívio com idéias conflitantes somente na aparência que, como veremos, é a tônica de São Marcos. De qualquer maneira, podemos partir aqui do pressuposto, aparentemente mais razoável, de que, após a experiência vivida no Calango-Frito, o narrador passou a acreditar nos poderes do feitiço; assumir esse ponto de vista será essencial para nossa interpretação da obra, como veremos.

Por tratar da diversidade religiosa brasileira, a narrativa apresenta vestígios de várias religiões. Assim é que a personagem Aurísio Manquitola, "um mameluco brancarano, cambota, anoso, asmático como um fole velho” (p. 231), pode ser associado a Cronos, o velho deus coxo do tempo, com a ceifadeira implacável nas mãos:

- Boa coisa é uma foice, hein, Aurísio? Serve para tudo... Agora, para tirar bichode-pé, serve não. Ou será que serve?...

- Não caçoa! Boa mesmo!... Eu cá não largo a minha. Arma de fogo viaja a mão da gente longe, mas cada garrucha tem seu nome com sua moda... Faca já é mais melhor, porque toda faca se chama catarina. Mas, foice?!: é arma de sustância - só faz conta de somar! Para foice não tem nem reza, moço... (p. 232)

Uma outra associação com Cronos, o Saturno dos romanos, nos é dada pela personagem “Saturnino Pingapinga, capiau que - a história é antiga - errou de porta, dormiu com uma mulher que não era a sua e se curou de um mal-de-engasgo, trazendo a receita médica no bolso, só porque não tinha dinheiro para a mandar aviar” (p. 225): 
referência ao engasgo sofrido por Cronos ao engolir a pedra que lhe fora dada por Cibele como se fosse o recém-nascido Júpiter, que Cronos pretendia devorar.

O nome do feiticeiro João Mangolô, segundo Roncari, parece ter origem africana, mas também pode ser relacionado ao termo grego para sortilégio, encantamento, manganeia ou manganon; a associação do nome do feiticeiro a um termo grego encerra uma “concepção de mundo, na qual as manifestações locais e particulares sempre atualizam modelos arcaicos universais” (RONCARI, 2004, p. 116), ou seja, a associação estabelece o vínculo entre o local e o universal a que já nos referimos; assim sendo, as referências religiosas de várias origens e épocas e as referências literárias e filosóficas clássicas, medievais e barrocas contidas em Sagarana posicionam o Brasil dentro de um contexto do pensamento universal, manifestado pelos grandes artistas e pensadores da humanidade. Visto dessa forma, o sertão brasileiro passa a ser um laboratório no qual podem ser observadas, através das ações intuitivas das personagens e das relações integradoras destas com o meio que as circunda, as manifestações de um pensamento de cunho universal.

Para Roncari, as atividades místicas de João Mangolô correspondem aproximadamente às do catimbó, sobre o qual Câmara Cascudo afirma que "é o melhor, é o mais nítido dos exemplos desses processos de convergência afro-brancoameríndia.” (RONCARI, 2004, p. 118). Segundo Eneida D. Gaspar, os catimbozeiros "geralmente são feiticeiros e curadores fortíssimos: fazem magias, retiram feitiços, curam doenças. Alguns são só benfazejos (trabalham “à direita”); outros são malfazejos (trabalham “à esquerda”); outros ainda fazem os dois tipos de trabalho" (GASPAR, 2004, p. 121).

Ao enfrentar e espancar João Mangolô, o narrador recupera a visão: “Outro safanão, e Mangolô foi à parede e voltou de viagem, com movimentos de rotação e translação ao redor do sol, do qual recebe luz e calor” (p. 254). A passagem faz referência a um astro menor, sem luz e calor próprios, dependente de um Sol, a hierofania que representa o astro maior, em volta do qual a Terra e os planetas giram; são assim ressaltadas, por um lado, a criação de um sistema religioso em equilíbrio, simbolizado pelo sistema solar, e, por outro, a dimensão cósmica dos fatos narrados, como se eles reproduzissem um evento mítico-cósmico que pode ser confirmado pela menção das hierofanias do Sol e dos astros no conto.

O narrador, num gesto pacificador, dá dinheiro a Mangolô: 
Havia muita ruindade mansa no pajé espancado, e a minha raiva passara, quase por completo, tão glorioso eu estava. Assim, achei magnânimo entrar em acordo, e, com decência, estendi a bandeira branca: uma nota de dez mil réis.

- Olha, Mangolô: você viu que não arranja nada contra mim, porque eu tenho anjo bom, santo bom e reza-brava... Em todo o caso, mais serve não termos briga... Guarda a pelega. Pronto! (p. 254)

O ajuste entre as duas personagens se faz por meio do acordo de convívio: o narrador, por medo, não mais se arriscará a desafiar os poderes da feitiçaria de Mangolô, porque sabe que poderá ficar cego ou sofrer dano maior - embora, por sua condição social superior à do feiticeiro, procure conferir feição de generosidade ao seu ato conciliador. Em Sezão, o narrador entrega a Mangolô a espingarda que levava ao ombro, ato que reforça a idéia de um armistício, e o poder de Mangolô é textualmente declarado: "Puz uns fiapinhos de cabelo seu, que eu arranjei... Mas não ia fazer nada... Bem que, se eu quisesse, tinha poder... Podia até ter matado Nhonhô... Mas não quis.” (ROSA, J. G., 1937, p. 291). Por outro lado, Mangolô, também coagido, não mais enfeitiçará o narrador, pois agora reconhece que este pode lançar mão da reza-brava para combater seu feitiço e puni-lo fisicamente (a condição de negro que viveu o período da escravatura dificultaria qualquer reação defensiva à agressão do branco).

A reconciliação do narrador com Mangolô é a fusão simbólica das crenças populares e universais existentes no Brasil. A reza de São Marcos, que salva o narrador, é a melhor forma de patrocínio dessa reconciliação, porque é paradigmática como fusão de crenças; na Idade Média, a oração forte foi uma das práticas preferidas das bruxas: nela se misturam Deus e os santos com demônios e elementos de magia. No Brasil, ela é resultado da mistura de várias crenças. O texto da oração forte de São Marcos referido por Câmara Cascudo (CASCUDO, 1969, vol 2, p. 167-8) não contém as partes que aparecem no texto de Rosa: "Em nome de São Marcos e de São Manços, e do AnjoMau, seu e meu companheiro...” (p. 232) e “Gonzazabim Indico”. (p. 232). Mas, seja qual for o texto que Rosa utilizou em São Marcos, nos dois breves trechos da reza mencionados pode-se notar a mistura de crenças.

Das considerações acima, podemos concluir que o narrador - que professa uma crença religiosa erudita e universal, mas não está isento de crendices, por ser brasileiro ao passar a acreditar em feitiços, percorre, na experiência de confronto com João Mangolô, o caminho que leva à compreensão de um sistema religioso popular também brasileiro, mas de múltipla origem. Graças ao caráter simbólico dessa fusão de crenças no conto, o conceito de religiosidade passa a compreender todas as manifestações do 
sagrado, resumindo, portanto, a feição da diversificada e complexa religiosidade brasileira.

A religiosidade contida em Sagarana é a da nossa formação religiosa e nada tem a ver com religiosidade pessoal de Rosa - que, a propósito, não pode ser detectada com precisão nem mesmo a partir de suas próprias declarações: “Eu não sei o que sou. Posso bem ser cristão de confissão sertanista, mas também pode ser que eu seja taoísta à maneira de Cordisburgo, ou um pagão crente à la Tolstoi. No fundo, tudo isto não é importante.” (COUTINHO, 1991, p. 92). Aliás, se considerássemos que as crenças religiosas das personagens de Sagarana retratam as crenças do autor, não haveria razão para deixarmos de considerar a violência contida no livro como o retrato da violência do próprio Guimarães Rosa.

Todos os domingos o narrador faz uma visita ao mato das Três Águas. Finge que vai caçar, mas, na verdade, seu objetivo é a observação atenta da natureza do local para, graças a seu olhar de intelectual, fruí-la contemplativamente como manifestação de riqueza e beleza da criação:

Mas cumpria com a lista, porque eu não podia deixar o povo saber que eu entrava no mato, e lá passava o dia inteiro, só para ver uma mudinha de cambuí a medrar da terra de-dentro de um buraco no tronco de um camboatã; para assistir à carga frontal das formigas-cabaças contra a pelugem farpada e eletrificada de uma tatarana lança-chamas; para namorar o namoro dos guaxes, pousados nos ramos compridos da aroeira; para saber ao certo se o meu xará joão-de-barro fecharia mesmo a sua olaria, guardando o descanso domingueiro; para apostar sozinho, no concurso de salto-à-vara entre os gafanhotos verdes e os gafanhões cinzentos; para estudar o treino de concentração do jaburu acromegálico; e para rir-me, à glória das aranhas-d’água, que vão corre-correndo, pemilongando sobre a casca de água do poço, pensando que aquilo é mesmo chão para se andar em cima. (p. 228)

O fato de ele ter de simular uma caçada para esconder o propósito de sua visita ao mato das Três Águas já indica a dissociação entre seus valores intelectuais e os dos habitantes do Calango-Frito. A prática da caçada, rejeitada pelo narrador, na concepção freudiana está ligada à satisfação de instintos: se realizada para garantir a sobrevivência, ao instinto de vida; se por prazer, ao instinto de morte.

$\mathrm{Na}$ concepção contemplativa do narrador observa-se uma mistura de platonismo, cristianismo, filosofia renascentista e aristotelismo - diz Roncari. Aristóteles parece estar presente em São Marcos "não só na idéia de contemplação, como também em várias outras concepções aqui elaboradas e, inclusive, na sua 
orientação geral” (RONCARI, 2004, p. 114), o que significa que o conto é concebido, de modo geral, dentro de um padrão filosófico aristotélico. Mas, afirma Roncari, "Essa perspectiva aristotélica da contemplação não exclui, na novela, a platônica, tal como exposta em Fedro, antes, a compreende”. (RONCARI, 2004, p. 115). Para Aristóteles, a atividade contemplativa é exercida por meio da razão e é a forma mais perfeita de o ser humano atingir a felicidade; de fato, a atitude contemplativa do narrador é fruto de seu intelecto requintado; a estreita relação entre intelecto e contemplação na personagem encaixa-se rigorosamente no que foi postulado por Aristóteles em Ética a Nicômano:

Se, portanto, a razão é divina em comparação com o homem, a vida conforme a razão é divina em comparação com a vida humana. (...)

para o homem a vida conforme à razão é a melhor e a mais aprazível, já que a razão, mais que qualquer outra coisa, é o homem. Donde se conclui que essa vida é também a mais feliz. (...)

Por conseguinte, a atividade de Deus, que ultrapassa todas as outras pela bemaventurança, deve ser contemplativa; e das atividades humanas, a que mais afinidade tem com esta é a que mais deve participar da felicidade. Mostra-o também o fato de não participarem os animais da felicidade, completamente privados que são de uma atividade dessa sorte. (ARISTÓTELES, 1973, X, 7, 1178a-b, p. 429-31).

O narrador dispensa a companhia de um cachorro em suas andanças pelo mato das Três Águas (p. 228). Um animal, que é exclusivamente guiado por instintos, não se ajustaria - como de fato não se ajusta - como companheiro de um dono contemplativo. Contudo, o risco sempre presente de se passar do estado contemplativo para o estado de selvageria está sempre presente e é fartamente evidenciado em outros contos de Sagarana, como, por exemplo, as metáforas do gavião-pinhé e dos urubus na página 180 de Minha gente e a descrição dos três poços grandes, nas páginas 191 e 192, no mesmo conto. O mesmo ocorre com a violenta agressão a que João Mangolô é submetido pelo narrador: ela mostra a existência, no mesmo indivíduo, do intelecto que o capacita para o exercício da contemplação, a mais alta manifestação do espírito, e do instinto de morte freudiano, pronto a vir à tona em vista de uma ameaça à integridade física, na forma da agressão mais animalesca e irracional: "Eu queria, precisava de exterminar o João Mangolô!... (...) Fui em cima da voz. Ele correu. Rolamos juntos, para o fundo da choupana. Mas, quando eu já o ia esganando, clareou tudo, de chofre” (p. 254).

A narrativa da contemplação da natureza pelo narrador se inicia com a passagem “Tiro o paletó e me recosto na coraleira.” (p. 245) e se estende até à página 247. E é 
então que, abruptamente, ele fica cego: "E, pois, foi aí que a coisa se deu, e foi de repente: como uma pancada preta, vertiginosa, mas batendo de grau em grau - um ponto, um grão, um besouro, um anu, um urubu, um golpe de noite... E escureceu tudo.” (p. 247)

De início, ele fica estupefato com a cegueira (p. 248); passa então ao pânico. Tem o impulso de apelar a Deus e a Santa Luzia, mas desiste, possivelmente pela fragilidade de sua fé cristã. Em vão tenta acalmar-se. O desespero o impede de discernir se no sul mora ou não o perigo (os pontos cardeais têm importantes significados simbólicos em Sagarana; de modo geral, o sul é benfazejo: remete à luz, ao progresso e à vida; o norte é o oposto: tem uma simbologia ligada ao mal, ao infortúnio, à sombra, à destruição, à morte):

Não é sonho, não é; pesadelo não pode ser. Mas, quem diz que não seja coisa passageira, e que daqui a instante eu não irei tomar a enxergar? Louvado seja Deus, mais a minha boa Santa Luzia, que cuida dos olhos da gente!... "Santa Luzia passou por aqui, com o seu cavalinho comendo capim!...” Santa Luzia passou por... Não, não passa coisa nenhuma. Estou mesmo é envolvido e acuado pela má treva, por um escurão de transmundo, e sem atinar com o que fazer. Maldita hora! Mais momento, e vou chorar, me arrepelando, gritando e rolando no chão. (...)

Espera, há alguma coisa... Passos? Não. Vozes? Nem. Alguma coisa é; sinto. Mas, longe, longe... O coração está-me batendo forte. Chamado de ameaça, vaga na forma, mas séria: perigo premente. Capto-o. Sinto-o direto, pessoal. Vem do mato? Vem do sul. Todo o sul é o perigo. Abraço-me com a suinã. O coração ribomba. Quero correr.

Não adianta. Longe, no sul. Que será? “Quem será?”... É meu amigo, o poeta. Os bambus. Os reis, os velhos reis assíriocaldaicos, belos barbaças como reis de baralho, que gostavam de vazar os olhos de milhares de vencidos cativos? São meros mansos fantasmas, agora; são meus. Mas, então, qual será a realidade, perigosa, no sul? Não, não é perigosa. É amiga. Outro chamado. Uma ordem. Enérgica e afiada, profunda, aconselhando resistência. (p. 248-9)

Após receber o impacto emocional provocado pela cegueira, o narrador tenta raciocinar de maneira ordenada, a fim de encontrar algum modo de sair da sua pavorosa condição. Mas o resultado que alcança é nulo:

Vamos! E por que não? Eu conheço o meu mato, não conheço? Seus pontos, seus troncos, cantos e recantos, e suas benditas árvores todas - como as palmas das minhas mãos. A ele vim por querer, é certo, mas agora vou precisar dos meus direitos, para defender o barato, e posso falar fala cheia, fora de devaneios, evasões, lembranças. Mesmo sem os olhos. Vamos!

Ando. Ando. Será que andei? Uma cigarra sissibila, para dizer que estou cômico. Fez-me bem. Mas, onde estarei eu, aonde foi que vim parar? Pior, pior. Perdi o amparo da 
grande suinã. Perdi os croticos das criações de pena da lagoa. E aqui? Este lugar é caminho de vento, e dos rumores que o vento traz: o sabrasil, à brisa, atrita as rendilhas das grimpas; as frondes do cangalheiro farfalham; as palmas da palmeira-leque aflam em papelada; e pá-pá-pá-pá - o pau-bate-caixa, golpeado nas folhas elásticas, funciona eloqüente.

Tomo nota: está soprando do sudoeste; mas, mal vale: daqui a um nadinha, mudará, sem explicar a razão.

E agora? Como chegar até à estrada? Quem sabe: se eu gritar, talvez alguém me escute, por milagre que seja. Grito. Grito. Grito. Nada. Que posso? Nada. E daí? Por mim mesmo, não sou homem para acertar com o rumo. Tomo fôlego. Rezo. (p. 251)

A total inutilidade do emprego da razão para auxiliá-lo é mais evidente em Sezão, em que seu discurso é científico, e o raciocínio lógico é reforçado pela álgebra; mas toda essa ciência só serve para fazê-lo chegar à extravagante conclusão de que, cego, vale um terço mais do que com a visão:

- Nada de alucinações! Isto é apenas o processo de adaptação à treva repentina e excepcional!...! E agora galopei com o pensamento, procurando jeito de ser frio e científico:...suponhamos... suponhamos que um cego recém-chegado, e portanto chucro, calouro, valha somente a terça parte de um homem... Mas, como eu estou calouro, de cérebro lúcido e vigilante, e tenho o conhecimento do terreno e mais a espingarda, posso atribuir a tudo isso um terço... Credito-me, e passo a ser dois terços de um homem... Agora: sei que estou correndo um qualquer risco, estou prevenido... Um homem prevenido vale por dois; dois terços de homem valerão no caso quatro terços... Logo, e apesar de tudo, eu estou valendo um e mais um terço... Mais do que um homem comum, portanto... (ROSA, J. G., 1937, p. 286).

Voltemos a Sagarana. O narrador recorda-se então das palavras escritas no bambual por “Quem-Será”, seu oponente no desafio poético, palavras que sugerem guiar-se pela sensibilidade, pelo coração, mais do que pela razão ou pelo instinto; mas refuta a sugestão, porque seu espírito racional o faz pensar que o coração não pode responder apropriadamente a todas as perguntas que a razão propõe sobre coisas irrisórias como aves, grilos e outras:

Me enfezo. Lembro-me de “Quem-Será”. E então?:

"para a esquerda fui. contigo.

Coração soube escolher.”

Sim. Mas, e as aves, e os grilos? Os pombos de arribada, transpondo regiões estranhas, e os patos-do-mato, de lagoa em lagoa, e os machos e fêmeas de uma porção de amorosos, solitários bichinhos, todos se orientando tão bem, sem mapas, quando estão em séca e precisam de ir a méca?... (p. 251)

Apela então para o instinto e faz-se guiar pelos próprios pés: “O instinto. Posso experimentar. Posso. Vou experimentar. Ir. Sem tomar direção, sem saber do caminho. 
Pé por pé, pé por si. Deixarei que o caminho me escolha. Vamos!” (p. 251). Mas, o instinto o fará piorar ainda mais sua condição, pois o leva a atingir o limite além do qual nunca se aventurara a ir: um lugar ameaçador, perigoso, traiçoeiro - como Piedade do Bugre, de Duelo. É aqui exemplarmente reforçado o conceito, já fartamente referido também nos outros contos de Sagarana, do risco contido na obediência cega aos instintos:

Sei desta aberta fria: tem sido o ponto extremo das minhas tentativas de penetração; além daqui, nunca me aventurei, nos passeios de mato a dentro.

Então, e por caminhos tantas vezes trilhados, o instinto soube guiar-me apenas na direção pior - para os fundões da mata, cheia de paludes de águas tapadas e de alçapões do barro comedor de pesos?!...

Ferido, moído, contuso de pancadas e picado de espinhos, aqui estou, ainda mais longe do meu destino, mais desamparado que nunca. (p. 252-3)

Recorda-se então de Aurísio Manquitola e da reza a São Marcos. Com a rezabrava é automaticamente levado até a cafua de João Mangolô. O catimbozeiro desfará o feitiço.

Façamos uma síntese do que dissemos acima e interpretemos os acontecimentos: o narrador é homem culto, erudito e intelectual, que, graças a esses atributos, consegue contemplar os prodígios da natureza em sua plenitude - fato que não impede que desça ao nível do bicho de um momento para outro. Aparentemente, é católico, mas sua fé é débil, como pudemos ver quando recorre a Deus e a Santa Luzia para auxiliá-lo. Seja qual for sua crença religiosa, ela não é manifestação exclusiva daquilo que chamamos de religiões populares. Seu credo, que pretende ser erudito como ele mesmo, apresenta a contradição inerente à religiosidade brasileira, pois é supersticioso. Esse comportamento paradoxal do narrador, no qual o acaso desempenha papel relevante, nada tem de científico, e é incompatível com sua própria religião. Sua superstição desloca a pressão psíquica interior para o mundo externo, e ele tende a "atribuir ao acaso externo um sentido que se manifestará em acontecimentos reais, e a ver no acaso um meio de expressão de algo que se oculta dele no mundo externo”, como afirma Freud, em Psicopatologia da vida cotidiana, sobre os supersticiosos, "pessoas freqüentemente muito inteligentes” (FREUD, 1989, vol VI, p. 223). O narrador desafia e rejeita as crenças populares, entre as quais a feitiçaria, porque tais crenças operam ou pretendem operar eventos que são cientificamente inexplicáveis e, portanto, incompatíveis com a razão científica. Mas justamente a fé que ele rejeita irá salvá-lo, quando fracassarem as tentativas de agir com lógica ou por instinto. A possibilidade de guiar-se pelo coração - 
sugerida por “Quem-Será” -, que acabou por salvá-lo, foi rejeitada a princípio, como vimos. Sua salvação ocorre quando ele integra suas crenças pessoais universais cultas com as crenças populares dos habitantes do Calango-Frito. Essa integração é a metáfora do conhecimento completo, porque, quando o erudito se completa com o popular, ele deixa de ver o mundo de forma parcial. A cantiga que epigrafa o conto, ao fazer referência aos equívocos provocados pela forma de ver o mundo em partes isoladas, já traz implícita a noção de que, para “espantar males”, é preciso ver o mundo na sua totalidade, caso contrário um coco será tomado pela cabeça de macaco ou, ainda pior: um homem, por um coco:

Eu vi um homem lá na grimpa do coqueiro, ai-ai, não era homem, era um coco bem maduro, ói-ói, não era coco, era a creca de um macaco, ai-ai, não era a creca, era o macaco todo inteiro, ói-ói.(p. 224)

Além da integração da parte com o todo, o que o episódio da cegueira do protagonista sugere é que guiar-se pela razão e pelo instinto, rejeitando a emoção, leva à cegueira, ou seja, à perda da visão, o mais divino dos sentidos, justamente aquele que leva o ser humano ao estado contemplativo da obra divina. Essa tese não soa estranha ao leitor das inúmeras declarações do próprio autor, que fala em literatura como “compromisso do coração” e rejeita a comparação de sua obra com a de James Joyce, por considerar este "um homem cerebral, não um alquimista” (COUTINHO, 1991, p. 75); e, perguntado por Lorenz sobre o conceito de brasilidade, Rosa responde:

quem quer que lhe tenha dito que a "brasilidade" é apenas uma baboseira deve ser um professor, um desses "lógicos" que não compreendem nada, que só compreendem com o cérebro; e, como se sabe, o cérebro humano é uma organização muito defeituosa e debilitada. Por isso o homem possui, além do cérebro, o sentimento, o coração, como queira. (COUTINHO, 1991, p. 90).

Quando Lorenz afirma: "Você está contra a lógica e defende o irracional. Entretanto, seu próprio processo de trabalho é uma coisa totalmente intelectual e lógica”, Rosa explica as razões pelas quais não há contradição alguma nesse fato, e conclui: “A lógica, prezado amigo, é a força com que o homem algum dia haverá de se matar. Apenas superando a lógica é que se pode pensar com justiça. Pense nisto: o amor é sempre ilógico, mas cada crime é cometido segundo as leis da lógica.” (COUTINHO, 1991, p. 93). Conteúdo similar ao das declarações acima, aplicadas à sua escrita, pode ser visto na sua carta a Bizzarri: "os meus livros, em essência, são anti-intelectuais defendem o altíssimo primado da intuição, da revelação, da inspiração, sobre o 
bruxulear presunçoso da inteligência reflexiva, da razão, da megera cartesiana.” (ROSA, J. G., 1981, p. 58). Sob essa ótica, sua noção do papel da intuição especificamente na estética se afina com a de Shaftsbury, segundo Casirier:

Doravante, a par do raciocínio e da experiência, uma terceira e fundamental força entra em cena, a qual, segundo Shaftesbury, supera todas as outras e oferece-nos, enfim, as verdadeiras profundidades da estética. Nem o pensamento "discursivo", tateando pesadamente de um conceito a outro, nem a observação lúcida e paciente de fenômenos particulares permitem atingir essas profundezas. Elas só são acessíveis a um "entendimento intuitivo" que não vai do indivíduo ao todo mas do todo ao indivíduo. A idéia de um entendimento intuitivo, de um intellectus archetypus, foi tomada por Shaftesbury do seu verdadeiro modelo filosófico, que é a doutrina plotiniana do "belo inteligível". Mas ele aplica esse pensamento num sentido novo e confere-lhe um ímpeto e uma ênfase que não possuía em Platão nem em Plotino. (CASIRIER, 1997, p. 417).

Nesta altura poderia ser levantada uma questão: se Guimarães Rosa em São Marcos e em suas declarações defende o sentimento, o coração, a intuição, e rejeita o lógico e o racional, como explicar a influência, sobre sua obra, de Aristóteles, o filósofo da lógica e que exalta o intelecto?

Em primeiro lugar, é preciso considerar que, na Poética, embora Aristóteles haja prescrito um esquema racional para a tragédia, estão presentes as emoções, os sentimentos, o que fica evidente quando o filósofo define aquele gênero dramático como imitação que se efetua "mediante atores, e que, suscitando o 'terror e a piedade, tem por efeito a purificação dessas emoções' ” (ARISTÓTELES, 1973, p. 447). O ataque de Rosa parece, na verdade, ser dirigido contra o cientificismo decorrente do racionalismo iluminista, que faz o narrador refutar o feitiço de Mangolô ou buscar saída científica para a cegueira; portanto, de acordo com essa noção, a crítica não seria dirigida contra a concepção aristotélica da razão, que leva o narrador a contemplar em profundidade os prodígios da natureza ou tentar descobrir "o fundamento ou razão de ser” das coisas (ABBAGNANO, 2000, p. 824), mas sim contra a parcela dos pensadores iluministas que propagaram a crença cega e apaixonada na autonomia da razão e no conhecimento científico, os mesmos que foram acusados com freqüência de terem “elevado a sua própria escala de valores, com uma ingênua suficiência, à categoria de norma universal” (CASIRIER, 1997 p. 14), depositando confiança excessivamente otimista na natureza humana e subestimando a força dos instintos, que teriam produzido insegurança, selvageria e barbarismo ao longo de toda história da humanidade. A refutação ao racionalismo científico, que em São Marcos só pode ser inferida, é 
confirmada em Conversa de bois, como veremos quando tratarmos do caso do boi Rodapião, um exemplar típico do racional iluminista.

Podemos dizer que Rosa é claramente influenciado pela obra de Aristóteles, assim como pela de outros filósofos, mas não podemos afirmar com segurança o quanto da obra aristotélica ele aceita como integralmente portadora de verdades inquestionáveis e imutáveis. É possível vislumbrar muitos pontos de concordância, mas também pontos de desvio do pensamento de Rosa em relação a Aristóteles, o que é previsível em alguém que põe em dúvida e em discussão tudo o que entendemos por verdade. As provas mais simples podem ser encontradas nos seus livros; nestes, são expostas idéias que se opõem diretamente ao racionalismo grego de Aristóteles, Platão e outros, sobre a linearidade da cadeia casual. São os casos, por exemplo, da frase de Riobaldo, "Tudo é e não é” e do parágrafo que abre A hora e vez de Augusto Matraga: "Matraga não é Matraga, não é nada. Matraga é Esteves” (p. 324), proposições que contradizem os “três princípios lógicos fundamentais, condições de toda a verdade” (CHAUÍ, 2001, p. 186): o da identidade $(\mathrm{A}=\mathrm{A})$, o da não-contradição (é impossível uma coisa ser A e não ser A ao mesmo tempo) e o do terceiro excluído (ou A é verdadeiro ou A é falso e não existe uma terceira possibilidade). Do mesmo modo, Rosa parece partilhar das idéias que Hobbes expõe na primeira parte do Leviatã, “Do homem”, o que não significa que também esteja de acordo com a terceira parte, a "Do Estado cristão”. Pensamos que Rosa - como a maioria das pessoas - se apossa dialeticamente dos conhecimentos dos filósofos que se ajustam à sua forma intuitiva, e não exclusivamente racional, de ver a vida e busca dar base racional consistente à sua compreensão intuitiva por meio da obra daqueles pensadores. A confissão de Rosa ao escritor angolano Joaquim de Montezuma de Carvalho em carta de 27/01/63 exemplifica adequadamente o que estamos afirmando; nela, ele reafirma seu credo anti-racionalista e sua crença de que as grandes verdades da humanidade vêm do espírito-do-coração:

Quanto ao QUESTIONÁRIO, porém, lamento não estar sendo capaz de atendê-lo, como bem gostaria. Tratei, durante estes dois meses, de fazer isso, com toda a boa-vontade, mas não o consegui. E o motivo é simples, até mesmo simplório. É que, eu mesmo ainda não encontrei as respostas para essas perguntas. Até hoje, não chego, a respeito de tais itens, a idéias nítidas, definidas. E quanto mais leio e medito, mais perplexo a vida, a leitura e a meditação me põem. Tudo é mistério. A vida é só mistério. Tudo é e não é. Ou: às vezes é às vezes não é. (Todos meus livros só dizem isso.) Tudo é muito impuro, misturado, confuso. Afora uma meia dezena de imperativos, que o espírito-do-coração da gente nos revela, e que os fundadores das religiões descobriram para a humanidade, o resto é névoa. 
À parte o que Cristo nos ensinou, só há meias-verdades. Por isso mesmo, a não ser como instrumento para soluções imediatas da vida pragmática, externa, do dia-a-dia, procuro cada vez mais guiar-me pela a intuição e não pela inteligência reflexiva. Sou um desertor. Abdico. Deixo de pensar em tudo “o que é de César”. Fujo das formulações, das definições, das conceituações mais ou menos rígidas e esquemáticas, das conclusões gerais. Rezo, escrevo, amo, cumpro, suporto, vivo, mas só me interessando pela eternidade. Só acredito na solução religiosa para o homem; para o indivíduo. Quando aprecio como fruidor uma obra de arte, sinto que isso é para que algo em mim se transforme. Quando faço arte, é para que se transforme algo em mim, para que o espírito cresça. (ROSA, V. G., 1999, p. 38990).

Em um momento da narrativa, o protagonista escreve em um bambu os nomes de dez reis assírios. Esses nomes despertam a sensibilidade poética do narrador e o faz pensar sobre o poder da palavra, mais do que no efeito que a beleza da linguagem desperta nos indivíduos:

E era para mim um poema esse rol de reis leoninos, agora despojados da vontade sanhuda e só representados na poesia. Não pelos cilindros de ouro e pedras, postos sobre as reais comas riçadas, nem pelas alargadas barbas, entremeadas de fios de ouro. Só, só por causa dos nomes. (p. 238).

\section{Em sua entrevista a Gunther Lorenz, Rosa afirma que:}

Meu lema é: a linguagem e a vida são uma coisa só.

Quem não fizer do idioma o espelho de sua personalidade não vive; e como a vida é uma corrente contínua, a linguagem também deve evoluir constantemente. Isto significa que, como escritor, devo me prestar contas de cada palavra e considerar cada palavra o tempo necessário até ela ser novamente vida. O idioma é a única porta para o infinito, mas infelizmente está oculto sob montanhas de cinzas. (COUTINHO, 1991, p. 83).

Na mesma entrevista, ao ser perguntado por Lorenz: "Uma vez você me disse que quando escreve quer se aproximar de Deus, às vezes demasiadamente. Certamente, isto também se relaciona com a língua. Como se deve entender isso?”, Rosa responde:

Isto provém do que eu denomino a metafísica de minha linguagem, pois esta deve ser a língua da metafísica. No fundo é um conceito blasfemo, já que assim se coloca o homem no papel de amo da criação. O homem ao dizer: eu quero, eu posso, eu devo, ao se impor isso a si mesmo, domina a realidade da criação. Eu procedo assim, como um cientista que também não avança simplesmente com a fé e com pensamentos agradáveis a Deus. Nós, o cientista e eu, devemos encarar a Deus e o infinito, pedir-lhes contas, e, quando necessário, corrigi-los também, se quisermos ajudar o homem. Seu método é meu método. O bem-estar do homem depende do descobrimento do soro contra a varíola e as picadas de cobras, mas também depende de que ele devolva à palavra seu sentido original. Meditando sobre a palavra, ele se descobre a si mesmo. Com isto repete o processo da criação. 
Disseram-me que isto era blasfemo, mas eu sustento o contrário. Sim! a língua dá ao escritor a possibilidade de servir a Deus corrigindo-o, de servir ao homem e de vencer o diabo, inimigo de Deus e do homem. A impiedade e a desumanidade podem ser reconhecidas na língua. Quem se sente responsável pela palavra ajuda o homem a vencer o mal (COUTINHO, 1991, p. 83-4).

A noção de que a palavra aproxima o homem de Deus, expressa no texto acima, é confirmada em São Marcos; ao dizer que "E não é sem assim que as palavras têm canto e plumagem” (p. 238), o narrador assimila a palavra aos pássaros, essas criações que simbolicamente relacionam o céu à terra. Essa mediação é evidenciada em duas passagens do desafio travado entre o narrador e a personagem desconhecida; na primeira, o urubu sai da terra e chega ao céu - "Na viola do urubu / O sapo chegou no céu” (p. 239) - e na segunda, o surucuá pintado por Deus é enviado do céu para a terra: “surucuá fugiu pra cá” (p. 240). Deste modo, a palavra terá duplo atributo: o de aproximar o homem do divino e fazer o divino aproximar-se do homem. Que o divino se aproxima do homem também pela palavra podemos inferir do que nos diz o próprio Guimarães Rosa: “Deus era a palavra e a palavra estava com Deus” (COUTINHO, 1991, p. 88); isso está igualmente subentendido no credo referido acima pelo autor. (COUTINHO, 1991, p. 83). Ao falar de aproximação do homem à divindade por meio da palavra, o autor sugere a possibilidade de as palavras terem significado mágico. Em algumas crenças, a sonoridade das palavras proferidas em determinados momentos não pode ser mudada, como acontece quando enunciados religiosos, portadores de significado na língua de origem, não são traduzidos quando os mesmos rituais são realizados em países de língua diferente. Exemplos atuais são as rezas em japonês da Igreja Messiânica e as rezas em sânscrito e tibetano no budismo; outro exemplo é o da missa rezada em latim, que tanta resistência encontra para desaparecer do ritual católico.

Se a língua pode ligar o homem a Deus, pode também ser uma arma: “à parte o sentido prisco, valia o ileso gume do vocábulo” (p.238). Portanto, a palavra deveria, por um lado, reunir o passado e o futuro, “à parte o sentido prisco”, recordando as suas origens e recuperando as acepções arcaicas perdidas; e, por outro lado, explorar as acepções novas e nunca tocadas, “ileso gume”, associando a palavra à lâmina e dando a ela um poder de separar ou religar.

O narrador continua seu discurso sobre a palavra, referindo-se, por exemplo, à necessidade de criação de um novo vocábulo para designar o enorme tamanho de uma árvore: "ao descobrir no meio da mata, um angelim que atira para cima cinqüenta 
metros de tronco e fronde, quem não terá ímpeto de criar um vocativo absurdo e bradálo - Ó colossalidade! - na direção da altura?” (p. 238). Conta que o capiauzinho analfabeto Matutino Solferino Roberto da Silva não entendia como a simples palavra “caixote" podia conter o biscoito fino que vinha naquela embalagem e achava que o termo deveria ser uma deturpação de algum mais difícil, como "talxóts". Narra ainda quatro casos em que destaca o poder fabuloso da palavra. O primeiro conta como seu amigo Josué Cornetas conseguiu ampliar os "limites mentais de um sujeito só bidimensional, ensinando-lhe as seguintes palavras: intimismo, paralaxe, palimpsesto, sinclinal, palingenesia, prosopopese, amnemosínia, subliminal” (p. 238-9). O segundo refere-se à população do Calango-Frito, que não gostava da fala fácil e compreensível do padre Geraldo, mas apreciava as palavras do defunto padre Jerônimo, "que tinham muito mais latim” (p. 239), como “sub lege libertas!”, simples frase que conseguiu abafar um motim iminente, num comício na cidade grande. No terceiro caso, o menino Francisquinho, depois de repetir quinze ou doze vezes a toada "patranha” em voz alta, voltou a ser selvagem, mostrando que a palavra, que tem o poder de aprofundar o espírito, também tem o de fazê-lo regredir. E, por fim, ele lembra o poder da frase, “Abre-te, Sésamo”, que escancara a porta da "gruta-cofre”.

O fato de Guimarães Rosa discorrer tão longamente sobre o poder da palavra em um conto que trata, entre outros, do tema da religião, leva à suspeita da existência de relação entre palavra e religião. O próprio autor nos auxilia a encontrar essa relação, quando afirma que “A religião é um assunto poético e a poesia se origina da modificação de realidades lingüísticas. Desta forma, pode acontecer que uma pessoa forme palavras e na realidade esteja criando religiões. Cristo é um bom exemplo disso” (COUTINHO, 1991, p. 92). Ao estabelecer uma relação direta entre religião e palavra, o narrador está nos dando a melhor explicação do fato de a salvação da cegueira da personagem se dar por meio de uma reza-brava. O que está em discussão no conto não é, portanto, o poder ou a vontade de Deus de restituir a visão a algum fiel desesperado que Lhe dirige uma prece, mas o poder da palavra contida na reza. Segundo Roncari, esse poder é tão importante, que a reza dá título à novela. (RONCARI, 2004, p. 125).

O bambual pelo qual o narrador passa em sua caminhada pelo mato das Três Águas é cenário de uma sub-história: um desafio literário entre o protagonista e “Quem-Será”, que começou quando o narrador encontrou inscrito em um bambu o seguinte poema: 
Teus olho tão singular

Dessas trançinhas tão preta

Qero morer eim teus braço

Ái fermosa marieta. (p. 238)

Segundo Roncari, nessa quadrinha, disfarçada com erros gramaticais próprios de quem não domina a língua e a escrita, é levantada a questão da relação entre o singular e o plural, do uno e do múltiplo:

Entre todos os erros, o recorrente é o da concordância entre o singular e o plural nos três primeiros versos (...)

Desse modo, os três primeiros versos podem ser lidos assim: dois olhos fundidos num só por um olhar tão único; uma cor tão preta que tornava uma só as trancinhas; e a vontade de morrer nos braços unidos num só abraço. O que os aparentes erros queriam enfatizar era a força do traço de união que reduzia a multiplicidade à unidade. (RONCARI, 2004, p. 123)

Não nos alongaremos na discussão filosófica sobre a relação do uno com o múltiplo, porque seria caminhar em terreno perigoso. Ao tema se dedicaram não poucos filósofos com idéias às vezes concordantes, às vezes discordantes entre si, como Aristóteles, Platão, Pitágoras, Parmênides, Heráclito, Filolau, Xenófanes, Empédocles e outros - para ficarmos somente nos gregos. O que nos interessa extrair dessa passagem é que “Quem-Será” procura comunicar a noção da relação do local com o universal, do uno com o múltiplo, e que essa quadrinha concentra, de fato, todo o sentido de São Marcos, o da integração da parte com o todo, do particular com o geral.

O narrador resolve então responder ao desconhecido “Quem Será”. E afirma:

E eu, que vinha vivendo o visto mas vivando estrelas, e tinha um lápis na algibeira, escrevi também, logo abaixo:

Sargon

Assarhaddon

Assurbanipal

Teglattphalasar, Salmanassar

Nabonid, Nabopalassar, Nabucodonosor

Belsazar

Sanekherib. (p. 238)

O narrador "vinha vivendo o visto", ou seja, vinha contemplando a natureza como criação divina e com ela se comungando por meio do intelecto e, ao mesmo tempo, dando vivas às estrelas - "vivando estrelas” -, isto é, cultuando o celeste. A sua resposta traz a busca de uma expressão intelectual, oposta, portanto, a de “Quem-Será”. Ele registra uma fieira de nomes de reis assírio-caldaicos, “rol de reis leoninos”, cujo 
poder, riqueza e a luxúria terrena de sua capital, a Babilônia, são mencionados nos dois Livros dos Reis, do Antigo Testamento. O que os nomes ressaltam, assim colocados, em versos, são a força e o poder do homem na terra, mas que se esgotam no tempo. Quando tomado pelo terror pânico provocado pela cegueira, o narrador recorda os nomes dos reis, que repercutem no fundo os toques surdos das marchas fúnebres, como aquilo que se esgota e perece com o tempo: gon, don, bonid, donosor (RONCARI, 2004, p. 123). Além disso, as letras iniciais das primeiras cinco linhas da mensagem do narrador formam a palavra "Satan", sugerindo o inferno que esses reis provocaram na terra. A associação de idéias do narrador, "Os reis, os velhos reis assírio-caldaicos, belos barbaças como reis de baralho, que gostavam de vazar os olhos de milhares de vencidos cativos?”. (p. 249), ligando sua cegueira com a causada pela selvageria dos reis contra os vencidos pode ser interpretada como associação de idéias no sentido psicanalítico, mas pode também ser uma referência ao fato de considerar sua cegueira obra de Satã.

No domingo seguinte, o narrador encontra no bambual o comentário do seu interlocutor desconhecido sobre a seqüência de nomes de reis assírios que deixara escrita: "Língua de turco rabatacho dos infernos” (p. 239), talvez empregando “infernos” com base em "Satan” E “Quem-Será” continua o desafio com uma nova quadrinha:

Na viola do urubu

O sapo chegou no céu.

Quando pego na viola

O céu fica sendo meu. (p.239)

Roncari assim comenta a resposta de "Quem-Será”:

a resposta vinha numa forma aparentemente simples, mas composta num sistema complexo, com um quiasmo, uma rima interior cruzada, que não é comum nas composições populares. A viola do início do primeiro verso rima com a viola do final do terceiro e o céu do final do segundo verso rima com o céu do início do quarto. Os dois versos centrais da estrofe, o segundo e o terceiro, criam um núcleo forte, com a condensação sonora dos finais de duas palavras do segundo, “sapo chegou”, numa palavra do terceiro, que funde as sílabas finais de sapo e de chegou: pego. E finaliza com o pronome possessivo meu, que repercute os us finais do primeiro e do terceiro versos. (RONCARI, 2004, p. 127)

A quadrinha transforma uma história do conto popular, - a do urubu que leva o sapo de contrabando a uma festa do céu - em assunto elevado, o do trânsito entre o terreno e o celeste. Por trás do aparentemente simples, portanto, estava oculto o complexo: bichos, como o urubu das carniças e os sapos dos pântanos, chegam ao céu e, ao mesmo tempo, o céu é trazido ao homem por meio da poesia contida nos versos do 
violeiro, porque “o céu fica sendo meu”. Desse episódio importa extrair a idéia de que “Quem-Será” estabelece, em sua resposta, uma integração entre o homem e o divino; trata-se, portanto, de uma variante do caráter da primeira quadrinha, “Teus olho tão singular”, etc. A posse do céu por “Quem-Será”, embutida no verso “o céu fica sendo meu”, está em contraposição à posse, pelo narrador, dos reis terrenos, satânicos, selvagens e arcaicos, na passagem acima referida: "São meros mansos fantasmas, agora; são meus” (p. 249). O narrador responde:

Tempo de festa no céu,

Deus pintou o surucuá:

com tinta azul e vermelha, verde, cinzenta e lilá.

Porta de céu não se fecha: surucuá fugiu pra cá.

E mais, por haver lugar:

Tem o teu e tem о теи tem canhota e tem direita, tem a terra e tem o céuescolha deve ser feita!

Eu mesmo não gostei. Mas a minha poesia viajara muito e agora estava bem depois do nascimento de Nosso Senhor Jesus Cristo. Isso me perturbou; escrevi:

Ou a perfeição, ou a pândega! (p. 240)

Ao contrário de "Quem-Será”, que canta o urubu, o narrador menciona o belo surucuá, que vem para a terra depois de ser pintado por Deus. Em um ou em outro caso, são as aves que fazem a intermediação entre o céu e a terra; os pássaros são assim assimilados aos anjos, porém para o narrador esses pássaros deverão ser forçosamente lindos, enquanto para “Quem-Será” eles podem ser urubus, pois também foram criados por Deus, como o surucuá. A segunda quadrinha, “Tem o teu e tem o meu” etc., fala da escolha que deve ser feita entre direita e esquerda. Roncari assim analisa a passagem:

A outra escolha era a da "pândega”, a festa terrena dos comes e bebes, de encher a pança, e que lembra a primeira das três árvores que analisaremos adiante, à qual ele pensa levantar "uma estatueta e um altar a Pan”. O verdadeiro recado passava a ser então o de que não havia alternativa à busca da perfeição e do celeste, cultuada pela poesia clássica, embora esta sempre estivesse ameaçada pelas forças terrenas do baixo e do grotesco de Pan, que vivia a desafiar a lira de Apolo, com a sua gaita de sete canudos, sirinx (RONCARI, 2004, p. 128).

No domingo seguinte, o narrador encontra a resposta de "Quem-Será”: 
eu tive de resolver:

para a esquerda fui, contigo.

Coração soube escolher! (p. 240)

“Quem-Será” diz que acompanha seu desafiante para a esquerda. O narrador havia tomado inicialmente o rumo da direita, seguindo por um caminho até ser alcançado por Aurísio Manquitola: "No final do feijoal, a variante se bifurca; tomo o carreador da direita” (p. 231). Após um longo diálogo que analisaremos mais adiante os dois homens se separam:

Bem, seu moço, se o senhor vai torar dessa banda de lá, nós temos de se desapartar, que o meu rumo é este aqui. Bom, até outro dia. Deus adiante, paz na guia!...

E o Aurísio Manquitola, se entranhando no mata-pasto e na maria-preta, some.

O meu caminho desce, contornando as moitas de assa-peixe e do unha-de-boi esplêndido, com flores de imensas pétalas brancas, e folhas hirsutas, refulgindo. No chão, o joá-bravo defende, com excesso de espinhos, seus reles amarelos frutos. E, de vez em quando, há uma sumauveira na puberdade, arvoreta de esteio fino e cobertura convexa, pintalgada de flores rubras, como um pára-sol de praia. (p. 236).

Depois da despedida, portanto, supomos que o narrador segue para a esquerda como referido por "Quem-Será” - e para baixo, percorrendo um caminho em que estão presentes duas feições opostas da natureza: a brabeza do joá-bravo e a beleza da unhade-boi e da sumauveira. Por seu turno, Aurísio pega o caminho oposto. A caminhada do narrador à esquerda tem conotação negativa na simbologia ocidental e, como seu percurso, além disso, se efetua para baixo, temos o mesmo caráter simbólico da descida de Dante ao Inferno: é a entrada no mundo do catimbozeiro que trabalha “à esquerda”, malfazejo, onde o narrador ficará cego; mas nesse caminho ele será acompanhado por seu desafiante, que lhe sugerirá que abandone a razão e o instinto e se guie pelo coração, conselho que termina por salvá-lo.

Podemos tirar algumas conclusões de tudo o que foi dito acima sobre o desafio entre o protagonista e “Quem-Será”. O que se observa é que o narrador procura, em todas as suas mensagens, evidenciar sua superioridade intelectual em relação a seu oponente: à menção de urubu e sapos, rebate com o saracuá e exorta o oponente a fazer a escolha entre a perfeição e a pândega, entre o erudito e o popular, exaltando o primeiro e depreciando o segundo. Cita nomes de reis seguramente desconhecidos para qualquer habitante do Calango-Frito, para se opor ao português trôpego da primeira mensagem de "Quem-Será”; dissemos acima que a seqüência dos nomes dos reis assírios dá a impressão de ter finalidade puramente sonora, uma espécie de ilustração do 
poder mágico da palavra. Mas podemos aventar uma possibilidade interpretativa adicional que não invalida as anteriores: o protagonista estaria fazendo uma poesia concretizante para demonstrar que é atualizado em assuntos de modernismo, portanto intelectualmente superior a "Quem-Será”, que decerto o desconhece. Do ponto de vista lingüístico, a seqüência de nomes é uma série paradigmática, não há relação sintagmática entre as palavras; elas não criam um texto retórico, como a poesia do “Quem-Será”. Isto poderá ser interpretado como provocação em relação à poesia de herança romântica, mas o próprio narrador em seguida faz uma poesia sintagmática - de conexões sintáticas capazes de criar um discurso retórico nos moldes tradicionais. Temos aqui duas possibilidades: ou aqueles nomes de reis não tiveram essa intenção estética provocadora, ou depois da resposta de “Quem-Será” o narrador-personagem se arrepende e volta atrás nas suas intenções de revolução estética. Particularmente, a segunda alternativa se nos afigura a mais acertada, porque em Sezão os nomes dos reis são precedidos por uma frase que denota seu caráter poético: “Ora, na ocasião, eu possuía um lápis no bolso e na cabeça uma boa concepção da poesia” (ROSA, J. G., 1937, p. 272); e, depois dos nomes dos reis, diz ele: "E eu já sonhava fazer escola, pois que, de acordo com a aludida intuição poética, isso tudo era um notável poema” (ROSA, J. G. , 1937, p.272).

O reconhecimento da derrota no desafio - “O tema se esgotara, com derrota minha e o triunfo de "Quem-Será”. Me vinguei, lapisando outra qualquer quadra, começo de outro assunto.” (p. 240) - pode ser visto sob duas perspectivas: a primeira é de caráter filosófico, porque as idéias que podemos extrair desse desafio são idênticas às que depreendemos na análise da cegueira do protagonista. Para este, se duas alternativas estéticas se apresentam, uma delas deve ser forçosamente excluída, raciocínio oriundo da lógica, do princípio do terceiro excluído; mas essa mesma lógica é rejeitada por “Quem-Será” e também por Guimarães Rosa em suas declarações. A segunda perspectiva é uma versão da alegoria contida na reconciliação do narrador com Mangolô, da qual falamos acima, e se refere à fusão das crenças populares e universais existentes no Brasil. Só que agora essa alegoria é ampliada: da fusão de religiões para a fusão entre erudito e popular, universal e local. O desafio com “Quem-Será” expressa o caminho do protagonista na fusão entre o erudito, o culto - que ele representou e defendeu como única solução artística e cultural - com o popular, que lhe é apresentado por “Quem-Será” como manifestação tão significativa quanto a erudita, uma vez que as duas se completam em uma totalidade. Em Sezão, essa ligação patrocinada por “Quem- 
Será” é claramente especificada, porque o desafio continua, e o narrador reconhece a influência recíproca e a troca entre ele e "Quem-Será”

Na semana que se seguiu, vim ansioso. “Quem-será” já tinha escrito:

O sofrer vermelho e preto

Vei pousar no pé do iper...

O sofrer canta tão triste

Que a arvre pega a tremer.

As flores caíno na lama

Só p’ra lama enriquecer...

Gostei e ri. Havia um retrocesso ortográfico. Mas havia também reticências. Era clara a influência que eu estava exercendo! Me vinguei, lapisando:

“Não é “iper”, seu burro! É “ipê”. E é árvore, e veio, e flores, e caindo. Mas está bonito, não há dúvida!”

E no terceiro bambu, porque para escrever no segundo já era preciso a gente se curvar muito, pus:

Em cortiça de iranchim

Tem cera, mel e ferrão...

Também tenho, para escolha,

Desprezo, raiva e paixão...

Deixa o marimbondo quieto,

Não bole com coração!...

Céus! Agora “Quem-será” é quem me está tocando influência!... Nesta gradativa dupla-troca, em breve chegaremos a um nível, à identidade musácea... Ótimo... E neste pé estamos nós. (ROSA, J. G., 1937, p. 275)

Ainda em Sezão, ao invés da referência à perfeição e à pândega, há uma passagem que completa a idéia de que a escolha de uma única fonte de inspiração artística ou religiosa, seja ela erudita ou popular, leva a enganos de tal ordem que faz identificar a mais celeste das mulheres, “Maria”, como portadora da maldade:

E eu, que já estudara a minha parte em casa, pespeguei:

Eu fui escrever Maria

(nome mais belo não há)

minha mão tremeu no meio

ficou só escrito: “Má”... (ROSA, J. G., 1937, p.274).

Luís Bueno, na introdução de seu Uma história do romance de 30, ressalta vários aspectos na obra de Guimarães Rosa a que estamos nos referindo nesta análise, como fusão entre cultura popular e erudita, a compatibilidade da linguagem com essa fusão, questões como razão e intuição: 
Para um intelectual como Guimarães Rosa, que, ao contrário de Graciliano Ramos, via com suspeita a racionalidade, sentindo falta de uma ligação mais forte do homem com a terra, sua própria natureza, o pobre, o sertanejo, o menino, o violeiro, o maluco, o jagunço não se diminuem em seu alheamento do mundo da intelectualidade. É bem o contrário disso. Sua estatura é aumentada, pois é de sua ligação ainda possível com o cosmo, por via da terra, que pode surgir a grandeza. O escritor, o artista, por sua vez, não é visto como intelectual pura e simplesmente. Mais do que isso, é alguém que, não totalmente engolido pelo discurso da lógica, é capaz de compreender outros discursos e plasmá-los na forma híbrida de conhecimento e intuição que é a obra de arte. Nessa perspectiva, as figuras marginais não são, portanto, um outro desagregado do artista, que tem aspectos de outro e tem aspectos de mesmo. (...).

A solução lingüística a que chegou Guimarães Rosa se liga naturalmente a essa concepção. A língua do pobre pode ser tomada com liberdade e reinventada no contato com uma tradição intelectual da em princípio mais arrogante alta cultura porque o artista é mesmo o único lugar em que essa fusão pode se dar. (BUENO, 2006, p. 24-5)

Uma indicação interessante sobre a atenção que o leitor deve dar à questão da integração das partes em São Marcos é dada na descrição das personagens de Saturnino Pinga-Pinga e Aurísio Manquitola: como vimos, as duas representam Cronos, mas a descrição do deus em cada uma delas é incompleta, porque apenas Saturnino sofre o engasgo e unicamente Aurísio carrega a foice; a composição completa da figura de Cronos somente é obtida pela junção das duas descrições. E esse Cronos resultante é brasileiro em todos os sentidos: nos nomes, nas crenças, na linguagem e na sua formação híbrida originada a partir de duas fontes complementares.

No nome “Quem-Será” fica implícita a questão sobre a identidade do oponente do narrador, que deverá ser respondida pelo leitor. O narrador, ao classificar seu interlocutor anônimo de "melhor amigo", talvez esteja se referindo às questões similares de que ambos se ocupam, concernentes ao que deve ser privilegiado no texto literário e, por extensão, nas manifestações culturais: se o parcial ou o universal, se o popular ou culto, ou ainda, se sua abrangência deve ser global, que incluiria o popular e o culto. Mas “melhor amigo” pode também significar que o narrador e "Quem-Será” compõem um conjunto solidário que contém a visão cultural sistêmica compreendida na fusão do popular com o culto, encontrada nas manifestações culturais brasileiras, como, por exemplo, na religião.

Roncari apropriadamente ampliou o conceito de aglutinação de crenças eruditas e populares na personagem para as duas fontes de inspiração, clássica e popular, na literatura do autor: 
Assim, muitas das percepções finas vividas com a leitura das fontes míticas e religiosas da literatura universal podem ser associadas às manifestações observadas e vividas no mundo rústico e arcaico do interior de Minas. Aos olhos do autor-narrador, uma coisa pode transformar-se na outra: o rústico e o arcaico do sertão - juntamente com a variedade da natureza, fauna e flora ricas e exuberantes - podem ser narrados numa forma culta; e os elementos e topos das narrativas universais podem ser revividos no meio rústico, ganhando novas roupagens e expressões. (RONCARI, 2004, p. 101).

A relação entre a alta cultura e a cultura popular era, segundo Roncari, uma questão em debate na literatura, na época em que Sagarana foi escrito, debate que foi protagonizado em termos teóricos e práticos pelos modernistas brasileiros na década de 1920 e que continuava na pauta da literatura de 1930. As relações do conto com o modernismo podem ser deduzidas da presença da figura de Zé Prequeté- “Mas não era comigo. Era com outro Zé, Zé-Prequeté, que, trinta metros adiante, se equilibrava em cima dos saltos arqueados de um pangaré neurastênico” (p. 228-9) -, que também aparece como figura pândega em Macunaíma e no Primeiro caderno do aluno de poesia, de Oswald de Andrade.

Escreve Roncari sobre o debate em torno da questão da relação entre a alta cultura e a cultura popular no modernismo:

A questão versava sobre a possibilidade e a validade dos contatos e trocas culturais, principalmente com as manifestações populares, não-cultas, e de como fazê-lo. (...)

A pergunta que se apresentava era esta: até que ponto era legítimo a alta literatura valorizar e absorver, como temas e formas, os elementos da cultura popular, como as várias tendências do modernismo tentaram fazer, principalmente com os da arte negra e indígena, expressivas de um tipo particular de subjetividade e religiosidade? Se essa volta e mergulho nas particularidades da cultura popular fossem pertinentes, como salvar os temas e os elementos da mitologia clássica, greco-romana, que tinham sido desprezados pelos modernistas? (RONCARI, 2004, p. 113).

O amor é outro tema tratado em São Marcos. Foi neste conto que Guimarães Rosa apresentou pela primeira vez de maneira sistemática o que Roncari chamou de teoria dos três amores.

Em certo momento da caminhada domingueira pelo bosque, o narrador faz a seguinte observação: “Agora vamos retroceder, para as três clareiras, com suas respectivas árvores tutelares; porque, em cada aberta do mato, há uma dona destacada, e creio mesmo que é por falta de sua licença que os outros paus ali não ousam medrar” (p. 
242). As três árvores reúnem os três arquétipos fundamentais que regem as várias dimensões da experiência amorosa. Eles aparecem como três árvores imensas na cabeceira da lagoa oval e especular.

A primeira árvore impera no Venusberg - o Monte de Vênus. Venusberg é onde se desenvolve o primeiro ato da ópera Tannhäuser, de Wagner, e no qual o protagonista experimenta as delícias do amor de Vênus. ${ }^{26}$ A descrição dessa primeira árvore - “um jequitibá vermelho, empenujado de liquens e roliço de fuste”, que impera no monte de Vênus - corresponde à do amor fálico, masculino e puramente carnal. O local inspira a busca instintiva da satisfação sexual, porque “Tudo aqui manda pecar e peca”. Proliferam aqui referências ao órgão masculino: cipós libidinosos, cogumelos “de aspirações mui terrenas”; reina a procura da ereção incessante, representada pela “erótica catuaba, cujas folhas, por mais amarrotadas que sejam, sempre voltam, bruscas, a se retesar” (a catuaba é considerada afrodisíaca). Diante do jequitibá, o protagonista pretende levantar "uma estatueta e um altar a Pan", o mesmo Pan que faz lembrar a frase “Ou a perfeição, ou a pândega!” (p. 240). Roncari refere-se a Câmara Cascudo para afirmar que Pan é uma entidade demoníaca associada ao bode nos ritos de feitiçaria (RONCARI, 2004, p. 135)

A segunda árvore, como revela o seu nome, “colher-de-vaqueiro” (p. 243), é essencialmente feminina. Ela é assim descrita por Roncari:

A segunda árvore é feminina por excelência: no nome, no comportamento e na forma, a qual se assemelha à da concha, como revela o seu nome "colher-de-vaqueiro”. Ela é descrita como um "monumento perfumoso", que seduz e rejeita ao mesmo tempo, como os seus escravos, também de formas femininas, de vulvas, “obcônicos”, que são mantidos a distância. Além das referências, “monumento perfumoso" e "faraônica”, o Egito é diretamente mencionado para indicar o que ela lembra: "Puro Egito”. Depois do cativeiro dos hebreus, na história de José, ele passou a simbolizar a pátria da sensualidade e do amor sensível. Essa árvore representa o amor puramente humano, desenvolvido como cultura e arte, voltado para satisfazer apenas os sentidos, os quais ele atiça e delicia com o uso de todos os artifícios: vestimentas e nudez, ornamentos e pinturas para a vista; perfumes e incensos para o olfato; sonoridades e cantos para os ouvidos; iguarias afrodisíacas para o paladar; e as mais variadas posições para maior satisfação do tato, transformando todas as

\footnotetext{
${ }^{26}$ O interesse de Rosa pela música não pode ser subestimado; Cleuza Martins de Carvalho chega à conclusão, a partir do exame das anotações de Rosa sobre música, de que "a musicalidade encontrada ou conquistada nos textos rosianos não surge somente do pleno domínio da língua e dos princípios estilísticos (...). É fruto de trabalho ativo com a música formal. Associa o texto com sua estrutura, subjugando as palavras a um esquema musical previamente estabelecido.” (CARVALHO, C. M., 1996 p. 196).
} 
partes do corpo em regiões eróticas e sensuais, de tal modo que o corpo inteiro se transforma em sexo. (RONCARI, 2004, p. 135-6)

Em Sezão, o traço sensual e egípcio da segunda árvore é ainda mais evidente:

Um claro mais vasto, presidido pela pirâmide perfumosa da colher-de-vaqueiro, de ramos densos, de flores rosadas, de casca lacrimejando resinas. Ainda não acertei com uma denominação decente para este lugar: si houvesse um pschent de pedra coifando cada um dos cinco cambarás ruivos, que crescem aqui perto e vão afinando de cima para baixo, seria o 'Vale dos Reis’ ou 'Thutmés em Karnak’. Só sei que isto aqui é Egito. (ROSA, J. G., 1937, p.278).

A terceira árvore é a "grande eritrina”, vermelha como sangue - erythrós em grego - e representa o amor gerador e fecundo, que se ergue como geratriz da vida e que contém o masculino e o feminino. O ambiente é descrito com doçura e símbolos de geração, como se a vida emanasse dela e girasse em torno dela; "é inteira e possibilita a continuidade de tudo, por isso transcende, traz futuro, permanência e imortalidade, o que a faz ser merecedora de um outro culto, diferente do de Pan” (RONCARI, 2004, p. 136):

Agora, sim! Chegamos ao sancto-dos-sanctos das Três-Águas. A suinã, grossa, com poucos espinhos, marca o meio da clareira. Muito mel, muita bojuí, jati, urussu, e toda raça de abelhas e vespas, esvoaçando; e formigas, muitas formigas marinhando tronco acima. A sombra é farta. E há os ramos, que trepam por outros ramos. E as flores rubras, em cachos extremos - vermelhíssimas, ofuscantes, queimando os olhos, escaldantes de vermelhas, cor de guelras de traíra, de sangue de ave, de boca e baton.

Todos aqui são bons ou maus, mas tão estáveis e não-humanos, tão repousantes! Mesmo o cipó-quebrador, que aperta e faz estalarem os galhos de uma árvore anônima; mesmo o imbêde-folha-rota, que vai pelas altas ramadas, rastilhando de copa em copa, por léguas, levando suas folhas perfuradas, picotadas, e sempre desprendendo raízes que irrompem de junto às folhas e descem como fios de aranha para segurar outros troncos ou afundar no chão. Mas a grande eritrina, além de bela, calma e não-humana, é boa, mui bondosa - com ninhos e cores, açúcares e flores, e cantos e amores - e é uma deusa, portanto.

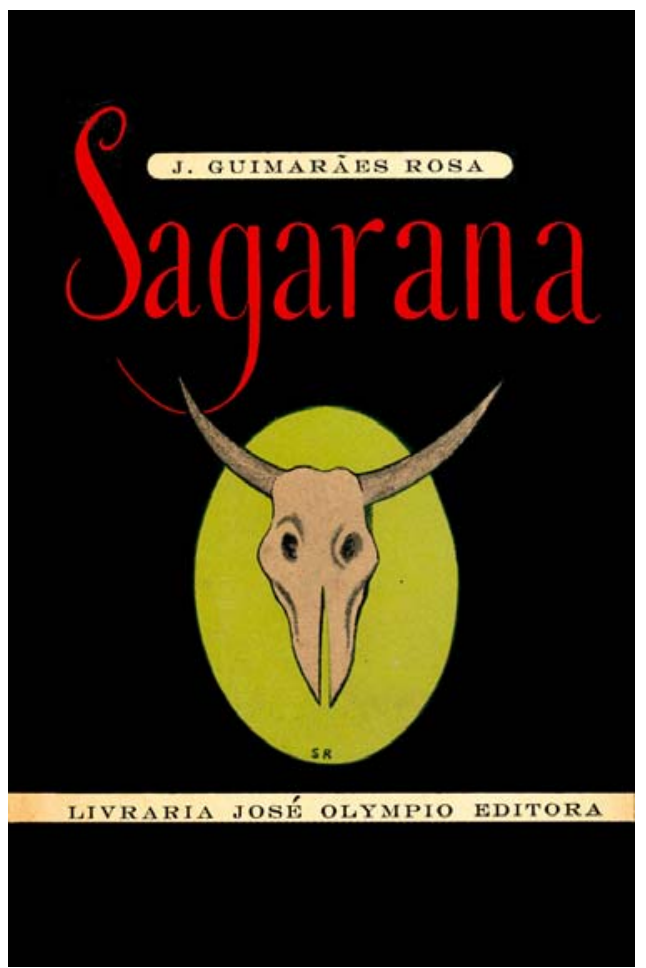

- Uf! Aqui, posso descansar. (p. 243) 
Roncari descreve então o ambiente no qual o narrador se instala, referindo-se ao ovo primordial da tradição órfica. Esse ovo é mostrado na ilustração de Santa Rosa para a capa da terceira edição de Sagarana:

Diante dele, ficava a lagoa oval, como o ovo primordial da tradição órfica, fonte de tudo, da vida e da morte, e que reunia também em si o que se multiplicava fora dela, estendendo-se como um espelho onde se reproduzia a natureza exuberante. Além de refletir o que the era exterior, aparecendo tudo invertido, "tomando um banho verde", ela continha em si uma vida própria, de peixes, pássaros aquáticos, insetos e cisqueira, inclusive o herói, um "joão-grande, contemplativo, ao modo em que eu aqui estou, sob a minha corticeira de flores de crista-de-galo e coral”, como se fosse o seu próprio reflexo. E tudo ainda se desdobrava com a luz do sol refletindo na lagoa e dividindo-a em duas, metade a metade, “E a lagoa parece dobrada em duas, e o diedro é perfeito”, quebrada em dois planos, um de luz e outro de sombra, como o ovo, fonte de vida e de morte. (RONCARI, 2004, p. 137).

Como o próprio Mangolô, que faz feitiços e, ao mesmo tempo, fala em Jesus Cristo - “Senh’us’Cristo, Sinhô!” (p. 229) -, Aurísio Manquitola, como vimos, é católico, mas teme o feitiço de Mangolô e acredita no poder das rezas bravas. Conta duas histórias sobre rezas: a primeira sobre a noite em que compadre Silivério viu Gestal da Gaita subindo pela parede do quarto em que os dois homens dormiam; a segunda, a de Tião Tranjão, que, graças a uma reza aprendida a muito custo de Gestal da Gaita, transforma-se em valentão e foge misteriosamente da prisão. Esta segunda história, além de falar do poder da reza e da palavra, tem o sentido adicional de mostrar a precariedade do estado de direito no Brasil, desde a narrativa da maneira do soldado deter Tião Tranjão, passando pela consulta deste a Antonino, seu patrão e padrinho, sobre se deveria ou não entregar-se, até o tratamento que recebe na prisão:

... E deu na conta: na hora em que o soldado chegou, Tião Tranjão, que sempre tinha tido um medo magro dos praças, foi perguntando, de pé atrás e fazendo ventania com o porrete:

- “Com ordem de quem?!”...

- "Com ordem de autoridade de seu Sebastião do Adriano, subdelegado de polícia lá no arraial e aqui também!”

- “Já sei, já sei! Volta p’ra trás! Volta p’ra trás, que eu vou sozinho, e é amanhã que eu vou. Falando manso, eu entendo; mas, por mal, vocês não me levam, e com soldado apertado é que eu não ando mesmo não!...”

Coisa que ele tinha quebrado o chapéu-de-palha na testa, e cuspiu para uma banda, porque estava mesmo dando para maludo, com as farrombas todas, mascarado de valentão. Mas o soldado logo viu que o assunto melhor era encabrestar e puxar o bobo pela ponta da bobice mesma. E falou assim: (...) 
- “O mais certo é a gente ir pedir opinião ao seu Antonino, que é seu patrão e seu padrinho, e o que ele aconselhar nós vamos fazer."

... Tião Tranjão ficou batendo com o pé na poeira, até que encheu e respondeu:

- "Pois se o senhor acha mesmo que eu sou par p’ra outro, vamos lá. O que Padrinho Antonino disser, "ta dissido!...”

... Aí seu Antonino falou na fé do falado, pelo direito, e mandou o Tião se entregar preso... (...)

- Diz-se que, lá na cadeia do arraial, os soldados fizeram graça... Diz-se que, não! me arrependo: eles fazem mesmo, eu sei, porque também já estive lá, sem ter culpa de crime nenhum, bem entendido; e eles, na hora em que eu cheguei, foram me perguntando: "Você matou? Ah, não matou não? Que pena!... Se tivesse matado, ia ficar morando aqui com a gente!...”

... Bom, eles trancaram o Tião. De certo que eles bateram também no Tião. (p. 234-5).

No aspecto racial, Aurísio Manquitola mostra “supersenso de cor e casta” (p. 231), pois declara abertamente não gostar de negros: "Não gosto de urubu... Se gostasse, pegava de anzol, e andava com uma penca debaixo do sovaco!...” (p. 231). O narrador igualmente declara não gostar de negros em seu contato com Mangolô, empregando um discurso racial da velha sociedade escravista, provavelmente para mostrar aos habitantes do Calango-Frito que tem a coragem de desafiar e humilhar um homem localmente reconhecido como detentor de fabulosos poderes sobrenaturais (p. 229-31). O racismo de Aurísio e o racismo manifestado pelo narrador contra João Mangolô exemplificam o racismo da própria sociedade brasileira .

Em um conto que trata de temas elevados do pensamento, como filosofia, linguagem, religião etc., o diálogo acima transcrito do narrador-personagem com Aurísio Manquitola dá uma indicação de que a tais assuntos se mescla uma representação do Brasil, o que nos impede de considerá-los como objeto final e absoluto do conto. Desse modo é estabelecida a coerência temática entre São Marcos e outros contos de Sagarana, nos quais os aspectos sociais têm relevância. Em Sezão, existe uma indicação adicional da vinculação entre os temas de São Marcos e uma representação do Brasil. Analisamos acima a quadrinha escrita pelo narrador nos bambus: "Deus pintou o surucuá” (p. 240); em Sezão, além de algumas variações, há uma segunda estrofe:

Quando Deus esteve alegre, inventou o sabiá.

Sabiá voou p'r'a mata, procurou tristeza lá... 
Por isso é que a gente chora

no lugar onde ele está... (ROSA, J. G., 1937, p. 274).

Esta segunda estrofe praticamente repete o sentido da primeira, mas adiciona o sabiá como portador da tristeza, acenando para Gonçalves Dias e o melancólico espírito romântico brasileiro, o “espírito do Calundú”, sempre apontado em Sagarana como causa de retrocesso.

Examinemos agora as similaridades de assuntos tratados em São Marcos com o pensamento de Graça Aranha contido em seu Estética da Vida, de 1921 a fim de orientar os temas presentes no conto para sua interpretação geral.

Eduardo Jardim de Moraes, em A brasilidade modernista, defende o ponto de vista de que o pensamento contido em Estética da Vida inspirou a elaboração de um ideário nacionalista desenvolvido pelos modernistas a partir de 1924. Afirma que o modernismo, com respeito a suas preocupações essenciais, apresenta duas fases nitidamente distintas no tempo, entre as quais foi editado o livro de Aranha. A primeira, iniciada em 1917 com a exposição de pinturas de Anita Malfatti em São Paulo, é de atualização e modernização inspirada nas vanguardas européias do momento e caracteriza-se como a da polêmica do modernismo com o passadismo. A segunda se inicia em 1924, com o Manifesto Pau-Brasil, de Oswald de Andrade, e se prolonga até 1929. É nessa segunda fase que o modernismo passa a adotar como primordial a questão da elaboração de uma cultura nacional. Eduardo Jardim estuda em seu livro dois autores de idéias políticas conflitantes, Oswald de Andrade e Plínio Salgado, para demonstrar que o conceito de brasilidade, tanto em um como em outro, foi elaborado sob inspiração do livro de Graça Aranha.

Em A Estética da Vida, segundo Jardim, podem ser vislumbradas duas categorias-chave em torno das quais se estrutura o ideário modernista de cultura nacional: a da intuição estética do todo, que possibilita a definição da nacionalidade e da alma brasileira e, aliada a ela, quase se confundindo, a categoria de integração do eu no cosmos, que caracteriza a possibilidade de superação do dualismo homem-cosmos. Tanto a categoria de intuição quanto a de integração estariam presentes no projeto modernista. As idéias contidas em Estética da vida podem ser sintetizadas nos tópicos que se seguem:

- Na origem da humanidade, o ser humano vivia uma condição inconsciente de integração com o todo infinito; a religião se identificava com a filosofia; 
- Em determinado momento da história da humanidade ocorreu na consciência humana a separação entre o eu e o cosmos; desse modo, o ser humano vive uma situação de dualidade, porque está separado do cosmos, do todo infinito;

- Essa condição de dualidade resultante da diferenciação entre o humano e do todo infinito é dolorosa e responsável pelo terror vivido pela consciência humana;

- A perpétua alegria pode ser alcançada pelo ser humano por meio da superação dessa condição de dualidade, isto é, pelo retorno à condição de origem na qual o humano era integrado ao todo infinito;

- O retorno à condição de origem, que propiciará a superação da dualidade, se realiza pela apreensão intuitiva da realidade, e não pela ciência, porque esta só é capaz de oferecer soluções parciais e imperfeitas;

- A intuição estética do todo possibilita a definição da nacionalidade e da alma brasileira;

- O universal só pode ser atingido pela afirmação do singular e, portanto, a integração do homem brasileiro com o universal depende da sua integração na própria realidade brasileira.

- O sentimento do todo infinito que funde o ser humano no Universo se realiza pelas sensações vagas e místicas da religião, da filosofia, da arte e do amor;

Religião, filosofia, arte e amor são alguns dos temas presentes em São Marcos, como vimos. É este fato que nos estimula a procurar no conceito de identidade brasileira de Graça Aranha elementos que nos auxiliem a dar uma interpretação global de São Marcos. Para levar a efeito esse propósito, faremos uma confrontação entre os temas acima mencionados, presentes no conto e as idéias de Graça Aranha sobre os mesmos temas, selecionando aquelas que possam nos auxiliar a enriquecer a interpretação da obra.

A relação entre o homem e o cosmos é um dos aspectos mais significativos do pensamento de Graça Aranha:

Na aurora do espírito humano a religião e a philosophia se confundem e dão do Universo a mesma visão. Pouco a pouco a investigação da materia, a interpretação scientifica da natureza crearam a philosophia e a distinguiram da pura religião. O senso religioso inseparavel do homem tornou-se philosophico. A philosophia veiu principalmente apoiar a religião, quando, quebrando a unidade do Todo, institue a perturbadora dualidade do espirito e da materia. Reapparece a funcção psychica do terror e de novo se volta, mesmo na extremada cultura da intelligencia, ao animismo primitivo, racial no homem. 
Procura-se ligar todos os effeitos ás causas, remontando até á causa unica creadora de todas as cousas. Repete-se com Parmenides que além do movimento ha o eterno repouso da substancia final, que attingiu ao maximo do seu desenvolvimento. A idéa de Deus se funde desse modo na metaphysica do terror, no simples animismo. A religião affirmase inexpugnavel no espirito do homem perdido na grande inconsciencia do cosmos. A actividade do homem, a sua acção pertinaz, o seu combate de todos instantes com a natureza, nada extirpa da imaginação nascida do terror o sentimento religioso que funde todo o Universo no conceito de uma substancia creadora das outras fórmas, que é Deus. (ARANHA, 1921, p. 18-9).

A proposta de Aranha é a da superação da dualidade entre o ser humano e o mundo, isto é, o retorno à situação original da humanidade, onde o homem e o cosmos se confundiam, retorno que se faz por intermédio das atividades intuitivas do espírito acima mencionadas.

Em sua entrevista a Lorenz, Rosa afirma estar empenhado na busca do infinito, na integração do eu no cosmos: “estou buscando o impossível, o infinito” (COUTINHO, 1991, p. 81); “O escritor deve se sentir à vontade no incompreensível, deve se ocupar do infinito” (COUTINHO, 1991, p. 89). Quando Rosa afirma que “O idioma é a única porta para o infinito, mas infelizmente está oculto sob montanhas de cinzas” (COUTINHO, 1991, p. 83), também participa da crença de Aranha de que, no alvorecer da história humana, o indivíduo e o cosmos eram inconscientemente integrados, e que, em algum momento, ocorreu a desintegração dessa unidade, dando lugar ao dualismo indivíduo-infinito; porém, para Rosa, o retorno à situação original se dará por meio do resgate do sentido primitivo da palavra, devolvendo-lhe o "sentido prisco”. Para Graça Aranha, “A língua exprime a grande desordem da formação nacional” (ARANHA, 1921, p. 188), afirmação que não se choca com as idéias de Rosa, mas, pelo contrário, a completa. Portanto, se São Marcos trata tão fundamente de questões referentes à linguagem, é porque está tratando também da integração da parte no todo, do indivíduo com o cosmo, do local no universal, e essa integração é a tônica do conto, como pudemos verificar em nossa análise.

Para Graça Aranha, o retorno à condição original da humanidade, na qual o indivíduo era integrado ao todo infinito, é a fonte da perpétua alegria, e para Guimarães Rosa o infinito é onde o diabo não existe: "na solidão pode-se descobrir que o diabo não existe. E isto significa o infinito da felicidade. Esta é minha mística. (...) Pois o diabo pode ser vencido simplesmente, porque existe o homem, a travessia para a solidão, que equivale ao infinito” (COUTINHO, 1991, p. 72) 
Ao discorrer sobre a arte, Graça Aranha defende o afastamento tanto das concepções naturalistas que propunham uma representação mimética do real, quanto das teses subjetivistas herdadas do Romantismo. Mas no caso brasileiro é, em primeiro lugar, contra estas últimas que é preciso reagir. Não que os ideais naturalistas não sejam também um alvo de sua crítica, mas é que, "tratando-se aqui do problema da alma brasileira, o traço fundamental de sua expressão artística é o lirismo de um romantismo amedrontado que melhor representa a tradição artística brasileira” (MORAES, E. J., 1978, p. 37). Voltamos assim ao “espírito do Calundú”, agora também criticado por Graça Aranha.

Como vimos, para Graça Aranha a idéia do alcance universal que a nossa arte deve ter “depende da sua inserção na própria realidade brasileira. O universal só pode ser atingido pela afirmação do singular. A dimensão universal da obra de arte depende, para ser alcançada, de que ela esteja integrada na realidade que a circunscreve”. (MORAES, E. J., 1978, p. 114). A observância deste preceito parece-nos um dos aspectos mais significativos da qualidade literária de Sagarana e faz dessa obra a portadora de um conjunto de elementos que podem ser aplicados na representação do Brasil. De fato, São Marcos mostra a convivência das fontes religiosas populares e cultas na sociedade brasileira. Ao mesmo tempo, o conto, como a totalidade de Sagarana, preconiza o convívio da cultura erudita com a cultura popular, do particular com o universal - não só na literatura, como na arte e na filosofia -, por meio de uma narrativa que coloca lado a lado a menção dos grandes clássicos do pensamento universal e a descrição artisticamente elaborada da cultura brasileira e se concretiza na escritura rosiana, que desconstrói o falar rústico para reconstruí-lo eruditamente. Sagarana emprega uma linguagem coesa em torno desse trânsito intercultural e, dessa forma, mantém estreita relação da técnica empregada na escrita com o sentido do texto. Converte-se assim em um livro tipicamente brasileiro escrito por um brasileiro de cultura universal que, com instrumentos de análise extraídos do pensamento universal, executa uma ampla representação do Brasil.

Na resenha de Sagarana mencionada por Roncari, Manoel Cerqueira Leite pergunta a forma de conciliar a cultura universal do autor com a escrita brasileira do livro e responde:

Se o autor e o contador tivessem só cultura informal, tudo seria simples: cairíamos na literatura em dialeto. Mas o caso é diferente: o autor, muito ao contrário do contador, é um homem erudito, de excepcional cultura. Como conciliá-los, como fundi-los? (...) 
Como conciliar estas incongruências? De maneira nenhuma! Não é necessário conciliá-las: elas existem como prova da dualidade apontada, a princípio, dualidade que o autor venceu nas melhores histórias, dando, de maneira magistral, uma demonstração de que se pode realizar, universalmente, aquilo que é restritamente regional, sem que nada se perca da verdade seivosa da vida” (Jornal de São Paulo, 10 fev. 1947 [IEB, CGR, PR1, p.45], apud RONCARI, 2004, p. 112)

Quando celebra um acordo tácito entre sua religião (culta com ressalvas) e a religião popular de Mangolô ou quando trava um debate poético com “Quem-Será” e reconhece sua derrota frente a um opositor que se manifesta em linguagem popular para demonstrar a propriedade da fusão do popular com o erudito - lembremos a quadrinha “Teus olho tão singular”, etc, da página 238 de Sagarana -, o narrador de São Marcos está confirmando um conceito de Graça Aranha, o de que o universal só pode ser atingido pela afirmação do singular e, portanto, que a integração do homem brasileiro com o universal depende da sua integração na própria realidade brasileira.

Outro ponto importante da concordância do pensamento de Rosa e de Aranha é a preponderância da intuição sobre a razão na definição de nossa identidade. Para Aranha, “A ciência não poderá jamais satisfazer a ânsia do espírito, que anseia realizar a unidade do cosmos.” (ARANHA, 1921, p. 19). Vimos que, na sua entrevista a Lorenz, Rosa critica os que só compreendem com o cérebro e acham que a brasilidade é apenas uma baboseira. (COUTINHO, 1991, p. 90); na mesma entrevista, reconhece a dificuldade de conceituar a idéia de brasilidade com precisão: “Sim, é certamente um assunto difícil e complicado. É lógico que existe a 'brasilidade’. Existe como a pedra básica de nossas almas, de nossos pensamentos, de nossa dignidade, de nossos livros e de toda nossa forma de viver. Mas o que é ela? Muita gente já quebrou a cabeça por causa do assunto.” (COUTINHO, 1991, p. 90-1). Mas, para ele, a brasilidade está intimamente relacionada à linguagem, e isso fica claro em outros dois trechos de sua entrevista a Lorenz; no primeiro está contido o conceito de que a existência de uma identidade nacional é confirmada na prática pelas diferenças realmente observáveis entre povos e entre suas línguas, e que povos de línguas diferentes são diferentes; na segunda, é explícita a noção de que a identidade nacional não pode ser descrita racionalmente como fez Gilberto Freyre - mas apenas intuitivamente, com o coração:

Sem que eu conheça a Alemanha, a língua alemã me mostra o que poderiam ter sido os alemães, se não tivessem esquecido a intimidade de Goethe com a metafísica da língua. Mas, quando se conhecem os alemães, o despertar é triste. (...) Com Dostoievski e a 
Rússia me ocorre exatamente o mesmo. Amo a língua russa, a língua da alma, e tampouco Dostoievski é responsável pelo atual estado da alma russa. (COUTINHO, 1991, p. 87)

Assim acontece com a "brasilidade"; nós dois sabemos a importância que tem e o que quer dizer; e também só o sabemos com o coração. Freyre esboçou uma definição muito boa, mas insuficiente. Se para sua explicação não usarmos novamente o mesmo conceito, "brasilidade”, não poderemos explicá-la fora de nossa área lingüística e sentimental. Eu pelo menos não posso fazê-lo, embora sinta esta "brasilidade" muito intensa, constantemente dentro de mim e apesar de ser o último a capitular ante um problema lingüístico. Se isto pode consolá-lo, digo-lhe que também fui um daqueles que quebraram a cabeça pensando sobre esta questão. Existem elementos da língua que não são captados pela razão; para eles são necessárias outras antenas. Mas, apesar de tudo, digamos também a "brasilidade” é a língua de algo indizível. Duvido que outras pessoas pudessem tirar disto uma conclusão mas, aqui entre nós dois, isto não é tão importante. (COUTINHO, 1991, p. 91)

A idéia de que a razão apenas consegue uma definição imperfeita da identidade nacional defendida por Aranha está igualmente presente no ideário modernista:

Os modernistas acreditavam (...) que para a definição da brasilidade o uso da categoria da intuição era de maior utilidade que o dos discursos sistemáticos. Estes últimos são vias de acesso que deformam o objeto inquirido. Em sua pretensão de objetividade, o discurso da ciência exclui, na definição da brasilidade, um aspecto fundamental que é preciso manter: o da vivência ou do sentimento da nacionalidade. (MORAES, E. J., 1978, p. 123).

O conceito de que a identidade nacional em Sagarana deve ser compreendida pela intuição, mais do que pela lógica, é implícito em São Marcos, porque o narrador, depois do episódio da cegueira e da tentativa fracassada de recuperar a visão com o emprego da ciência inútil e do instinto catastrófico, passa a acreditar em feiticeiros; se sua reconciliação com Mangolô tem o sentido alegórico do convívio de religiões populares e cultas no Brasil, o resultado é que na alegoria está embutida a idéia de que a compreensão da religiosidade contida na reconciliação se faz pela intuição, mais do que pela razão. A crença, comum aos dois autores, da impossibilidade de descrever plenamente a alma brasileira por meio da ciência, pode ser o motivo pelo qual Guimarães Rosa nos apresentou suas idéias sobre o Brasil por meio de nove contos de ficção.

Na parte de A estética da vida intitulada “Metafísica brasileira”, Graça Aranha faz um retrato diagnóstico do Brasil. A nacionalidade é definida por meio dos traços psicológicos coletivos que constituem a alma brasileira. A nacionalidade ou a alma da 
raça não pode ser explicada, mas intuída através de uma espécie de psicologia profunda da coletividade. Graça Aranha assim expõe seu diagnóstico:

No Brasil o traço característico collectivo é a imaginação. Não é a faculdade de idealisar, nem a creação da vida pela expressão esthetica, nem o predominio do pensamento; é antes a illusão que vem da representação do Universo, o estado de magia, em que a realidade se esváe e se transforma em imagem.

(...) Assim desabrochou essa sensibilidade implacável, que engrandece e deforma as cousas, que exalta e deprime o espírito, que traduz as ancias e os desejos, fonte turva de poesia e religião, por onde aspiramos a posse do Infinito, para logo nos perdermos no nirvana da inacção e do sonho. (ARANHA, 1921, p. 86-7)

O contato da alma brasileira com a natureza é inadequado porque é feito por intermédio da imaginação; como a integração do espírito humano na natureza que o envolve é condição para a integração no cosmos universal, resulta que a alma brasileira está condenada a permanecer dentro da estrutura dualista da diferenciação eu-cosmos. Vimos que a imaginação, como apontada por Aranha, está presente nos devaneios de Lalino, de A volta do marido pródigo e do Primo, de Minha gente.

Em uma conferência editada em livro em 1925 com o título O Espírito Moderno, Graça Aranha expôs a plataforma de um projeto de construção da cultura nacional. Nessa mesma conferência ele apresenta uma definição do espírito nacional que contém críticas veementes à postura nacionalista de Oswald de Andrade. Este fato acabou por gerar a polêmica que pareceu a alguns autores ter levado à separação dos grupos modernistas carioca e paulista. Manuel Bandeira, com serenidade, assim se expressou sobre essa polêmica em carta a Carlos Drummond de Andrade: "Pensando bem, creio que no fundo estão todos de acordo, e o problema é enquadrar, situar a vida nacional no ambiente universal, procurando o equilíbrio entre os dois elementos” (Carta de 21/10/1924, incluída no segundo volume de Poesia e Prosa, apud MORAES, E. J., 1978, p. 31). Essa é, sem sombra de dúvida, a melhor visão sobre a relação entre o local e o universal que pode ser extraída dos fatos narrados em São Marcos. Ao pôr em discussão a relação entre a cultura universal e a cultura popular em Sagarana, Guimarães Rosa está implicitamente confirmando seu envolvimento e tomando uma posição nesse debate referente a questões relativas à definição de espírito nacional.

A concepção de Graça Aranha sobre o amor difere em alguns aspectos da exposta em São Marcos. Em A Estética da vida, no capítulo dedicado ao tema, Graça Aranha também faz a distinção entre amor animal e amor humano. Mas, para ele, o 
amor humano, ao unir espiritualmente dois seres, representa uma forma de retorno à unidade primitiva:

Os seres ephemeros, que são os seres humanos, attingem por um instante á eternidade, sáem da diversidade consciente em que o terror os exila, voltam á Unidade primitiva do Todo universal, quando os arrebata a paixão do amor. Como explicar esse sentimento sublime e commum que, partindo da sensibilidade physica, se eleva á mais alta espiritualidade? Se na base do amor se encontra a ancia da satisfação do instincto, não é esta sufficiente para explicar a paixão que domina a sensualidade, funde as emoções psychicas dos Amantes e compõe dos dois seres que se attráem e se unem, um só todo espiritual. Se o Amor não é possivel sem a attraç̧ão physica, esta póde realisar-se em toda a plenitude sem chegar á maravilha do amor. A attracção physica existe entre os innumeros seres do Universo, os animaes superiores a sentem imperiosamente e por ella se perpetuam as especies, mas, pelo phenomeno psychico do amor, os homens se distinguem - dos outros animaes. (ARANHA, 1921, p. 60-1)

Ele então pergunta: "Porque essa attracção infinita e irremediavel entre os seres que os funde no Universo?” (ARANHA, 1921, p. 62). Responde que Platão, em $O$ banquete, percebeu uma parte importante da verdade do amor, ao criar a figura do andrógino, que é a condensação dos semelhantes realizada em um só corpo. Deste modo, Platão descobriu que todo ser humano aspira à unidade com o Todo universal, de que a consciência metafísica separa. E completa, afirmando que se Platão :

fosse mais ousado, perceberia que ha uma unidade essencial e inicial do Universo, e que os seres deviam existir eternamente na indistincção absoluta. Mas, separados do Todo universal, a vida interior dos seres humanos, fundamentalmente levados a se confundir com o Universo, é a continua e irreprimivel aspiração á Unidade primitiva. (ARANHA, 1921, p. 65-6).

Como se vê, o amor recebe no A Estética da vida o mesmo tratamento dado aos quatro fatores que possibilitam a intuição estética do todo e, por conseguinte, a definição do conceito de espírito nacional. A terceira forma de amor apresentada em São Marcos, a do amor mais elevado, tem em comum com a de Graça Aranha o fato de ambas representarem a condensação do amor masculino e feminino. Mas, para Guimarães Rosa essas formas de amor assumem, além das categorias de masculino e feminino, também as de amor instintivo e de amor de sedução, respectivamente; a concepção de amor de Guimarães Rosa contém a de Graça Aranha, graças ao retorno à unidade primitiva contido na referência explícita ao “ovo primordial da tradição órfica”.

Esquematicamente, portanto, podemos dizer que, para os dois autores, a definição da espírito nacional se faz por meio da intuição e depende da integração do 
indivíduo brasileiro com o universal, da parte com o todo. Para Rosa, o resgate da linguagem é a condição para compreender o caráter nacional por duas razões: por um lado, a linguagem é o espelho do próprio caráter do povo e, por outro, ela integra o homem ao infinito. Para Graça Aranha, a fusão do ser humano no Universo se realiza pelas atividades intuitivas da religião, da filosofia, da arte e do amor, temas presentes em São Marcos, como vimos: a integração do local com o universal se faz na religião, por meio da integração metafórica dos conceitos religiosos do narrador com os Mangolô, e na arte - especificamente a literatura - com as noções filosóficas e poéticas de “Quem-Será” assimiladas pelo narrador. A filosofia também integra o homem com a natureza por meio da atitude contemplativa do narrador e, ao mesmo tempo, é mostrado o risco da queda do homem no estado instintivo. O amor é também tratado no conto e em Estética da vida, com as diferenças já apontadas. E o espírito romântico é criticado pelos dois autores por ser considerado um problema da alma brasileira e um traço fundamental negativo de sua expressão artística.

Neste trabalho restringimos a função da obra de Graça Aranha a fonte auxiliar na junção dos temas presentes no conto, isentando-nos, portanto, de formular qualquer tese - por muito interessante que ela possa ser - sobre a eventual influência do Estética da vida no pensamento de Guimarães $\operatorname{Rosa}^{27}$ ou, principalmente, sobre as diferenças conceituais daquilo que seria a identidade nacional para cada um dos dois autores. $\mathrm{O}$ termo "brasilidade”, que ambos empregam, carreia, no sentido comum, uma dose de ufanismo que foi acentuado pela revolução de 30 num programa cultural que visava a propagar o orgulho pela condição de brasileiro. Mas esse não é, de forma alguma, o sentido que pode ser vislumbrado em Sagarana; aqui, o conceito se aproxima do que

\footnotetext{
27. O raciocínio de Graça Aranha pareceu superficial a Antonio Candido, embora este reconheça a adesão dos modernistas à "filosofia cósmica e superficial, que alguns adotaram em certo momento nas pegadas de Graça Aranha” (CANDIDO, 2002, p. 120). Mário de Andrade refere-se à influência exercida por Graça Aranha no Modernismo: "E eis que Graça Aranha, célebre, trazendo da Europa a sua "Estética da Vida, vai a São Paulo, e procura nos conhecer e agrupar em torno da sua filosofia. Nós nos ríamos um bocado da "Estética da Vida" que ainda atacava certos modernos europeus da nossa admiração, mas aderimos francamente ao mestre. (ANDRADE, M., 2002, p. 257). Ao relatar o encontro de Graça Aranha com Alceu Amoroso Lima em Paris, em 1914, Otto Maria Carpeaux afirma que o primeiro "propõe ao jovem bacharel uma campanha de modernização literária e filosófica do país: são os pré-sinais daquilo que será, um decênio mais tarde, a batalha do modernismo brasileiro” (CARPEAUX, 1978, p. 26). No entanto, Amoroso Lima em 1921 escreveu um ensaio, Graça Aranha pensador, no qual faz severas críticas ao Estética da vida, afirmando que:

Desejoso de libertar-se das contingências terrenas, para ascender às puras regiões arbitrárias e inebriantes do Infinito, procura o Sr. Graça Aranha conciliar em seu sistema todos os contrários. No fundo, é um adversário irredutível (filosoficamente, já se vê), da moral, da ciência e da ação, e um puro amante do êxtase contemplativo. (LIMA, 1969, p. 433).
} 
neste trabalho vimos chamando de representação do Brasil: o conjunto de relações culturais, econômicas, sociais, muito particulares, distintas da de outros países, que vêm de nossa historia colonial e perseveram até hoje. Nessas relações particulares, a lei é ausente, a violência e a falta de coesão social estão mais presentes nas esferas pública e privada do que as relações institucionais que deveriam patrocinar um contrato social. No texto rosiano, a mistura de um pouco de ordem em muita desordem, um pouco de civilidade em muita violência, são assinalados com tal redundância, que acabam se convertendo em traço característico do país, a emperrarem a instauração de algo próximo de civilização. Sobre o significado desta última em Sagarana, discorremos na análise de $O$ burrinho pedrês.

Em São Marcos a representação do Brasil se faz pelo desenvolvimento conceitual dos temas a que acima nos referimos, o que não significa, obviamente, que Guimarães Rosa e Graça Aranha pensem da mesma forma sobre como seja o Brasil. A violência não é aqui abordada claramente, uma vez que as suas múltiplas faces são mais clara e exaustivamente desenvolvidas ao longo de todo o livro. Como regra geral, o conto não preconiza um projeto de elaboração de uma cultura nacional, como em certo momento se empenharam os modernistas e o próprio Graça Aranha, mas apenas fornece elementos para ajudar a compreender como a cultura se manifesta em nosso meio social; talvez a discussão sobre a relação do local com o universal possa, como sentido adicional, conter um credo do autor que se evidencia na mistura do popular com o erudito presente na narrativa.

Convém aqui fazer uma observação no que se refere à metodologia de análise literária que estamos empregando neste trabalho. Parte das nossas afirmações sobre São Marcos decorre de conhecimentos que, aparentemente, são externos ao texto e poderiam caracterizar a tentativa de vasculhar a intenção do autor, ou seja, cair na falácia intencionalista. O procedimento que adotamos foi sugerido pela proximidade do narrador do conto com o "autor implícito” a que se referiu Booth. Quando lançamos mão das noções pessoalmente transmitidas por Rosa sobre a palavra, por exemplo, estávamos, na verdade, escolhendo a via argumentativa mais curta, porque, de fato, no texto existem elementos que especificam claramente o poder transformador da linguagem, a integração do particular com o universal na arte e na religião brasileiras, bem como a atitude contemplativa como forma de integração do homem com a natureza; e se fala do Brasil, porque se fala da arte, da religião, do preconceito racial e 
das instituições brasileiras. Portanto, frisamos que as idéias pessoais de Rosa foram tomadas somente como orientação de leitura para confirmar e reforçar a presença da representação do Brasil no texto; ao mesmo tempo, recorremos a Estética da vida de Graça Aranha como forma de facilitar e orientar a detecção da presença do conceito de identidade nacional no conto. O procedimento que adotamos, que consistiu em recorrer a fontes auxiliares para servir de guia na interpretação, é compatível com a prática hermenêutica, desde que tudo o que for utilizado de tais fontes seja confirmado, ou pelo menos não seja questionado, em nenhum ponto interno ao texto. 


\section{CORPO FECHADO}

Se $O$ burrinho pedrês é o conto no qual se mostram os efeitos sociais do bom governo, Corpo fechado mostra os efeitos do desgoverno. De fato, este é um conto paradigmático na demonstração das conseqüências sociais da ausência de instituições aptas a conter a violência. Todos os acontecimentos narrados apontam sistematicamente para essa idéia central. As personagens representativas das forças que deveriam patrocinar a agregação social e conter a instalação da condição de selvageria são inoperantes: o coronel, o subdelegado de polícia e o vigário. Como conseqüência da ineficácia dos poderes ordenadores do comportamento social, valentões e embusteiros acabam por atuar com desembaraço. Instala-se o estado de desordem generalizada; muitas personagens do conto são alcoólatras, viciados em cachaça ou cerveja, incluindo-se entre elas o próprio protagonista, Manuel Fulô. Nessa história de valentões o o que se tem é a história de seres que cometem violência e são vítimas de sua própria violência. Fazer vítimas e tornar-se vítima da violência geral significa, em última análise, retornar ao estado de selvageria.

Já no primeiro período do conto é narrada pelo protagonista ao narrador a morte do valentão José Boi, que gastava em cachaça tudo o que ganhava, que enfrentara três militares e quebrara o pescoço ao cair de um barranco:

José Boi caiu de um barranco de vinte metros; ficou com a cabeleira enterrada no chão e quebrou o pescoço. Mas, meio minuto antes, estava completamente bêbado e também no apogeu da carreira: era o “espanta-praças”, porque tinha escaramuçado, uma vez, um cabo e dois soldados, que não puderam reagir, por serem apenas três. (p. 256)

No trecho acima são evidentes a presença da violência privada, o confronto físico entre o indivíduo e a instituição mantenedora da ordem social, a fragilidade da autoridade física e moral dessa instituição, bem como a admiração e o temor que o povo nutre pela figura do valentão. Esses, entre outros, de que também trataremos, são os elementos do conto que nos permitem conceituar a noção presente em Corpo fechado: quando o Estado não se apresenta como detentor do monopólio da violência legítima, pode surgir o valentão que, de forma arbitrária, se sobrepõe à autoridade legalmente constituída, quando não a substitui. Sua principal característica, conforme se pode deduzir do conto, é o emprego arbitrário da violência, muitas vezes confundida com coragem pela população. A exaltação do valentão pela população tem, em essência, a mesma origem da exaltação do jaguncismo e do cangaço e, da mesma forma que 
jagunços e cangaceiros, o valentão convive com freqüência lado a lado com as autoridades. Sezão mostra algumas passagens sobre Targino, o valentão do momento na Laginha, que merecem ser transcritas, por mostrarem os aspectos de que estamos tratando; embora ele seja responsável por várias mortes - como deixa claro quando diz a Manuel Fulô que pretende visitar a noiva deste no dia seguinte: "Eu venho visitar ela amanhã. Aviso porque já estou farto de conduzir gente p’r’a cova e quero sossego!...” (ROSA, J. G., 1937, p. 252) -, ele se move com naturalidade no meio e se relaciona normalmente com o vigário e com o mandante local: “Transitava calmamente pelo arraial; as pessoas mais distintas abraçavam-no com afagos e gracejos; beijava a mão do vigário; ia à missa. Assinou o telegrama coletivo do Diretório político ao Presidente do Estado, encabeçado pelo coronel Mingote.” (ROSA, J. G., 1937, p. 237).

No diálogo entre o narrador e Manuel Fulô, que inicia o conto, o segundo faz uma exposição da fileira de valentões que já passara pelo local, cada um em seu tempo, um substituindo o outro e cada um chegando ao fim da vida de várias formas: vítima de morte violenta, preso ou aposentado: José Boi, “Bom homem... Muito amigo meu” (p. 256), Desidério Cabaça, "bruto como ele só, e os outros tinham medo dele. Cavalo coiceiro...” (p.256), Dêjo, “Um peste. Muita prosa, muita farroma” (p. 257), “Cachorro! Morreu de erisipela na cara...” (p. 258), Miligido, que “era bom... Homem justo. O que ele era era preto... Mais preto do que os outros pretos, engomado de preto... Eu acho que ele era preto até por dentro! Mas foi meu amigo. Valentão valente, mesmo” (p. 258). ${ }^{28}$

Targino é descrito por Manuel Fulô como cobra que pisca olho... Quando ele embirra, briga até com quem não quer brigar com ele... Nenhum dos outros não fazia essa maldade... O senhor acha que isso é regra de ser valentão? Eu sei que, por causa de uns assim, até o Governo devia era de mandar um quartel de soldados p'ra aqui p'ra a Laginha... (p. 258).

Esta última frase dá mostra do que representam as instituições legais para Manuel Fulô: a intervenção do governo é nociva a ponto de só se justificar, como última alternativa, para reprimir alguém como Targino. Conhecedor da inoperância das autoridades que deveriam neutralizar o valentão, ele espera que a intervenção divina resolva o assunto:

\footnotetext{
${ }^{28}$ Em Sezão é citado outro “subvalentão”, Adriano:

Tinha o Adriano, homem reconhecidamente homem. Mas este estava tolhido: não queria dar motivos para uma disputa de família, - desde que tinham nomeado seu irmão Odorico sub-delegado de polícia, Adriano se fizera legalista e conservador. (ROSA, J. G., 1937, p. 237).
} 
Eles todos já foram castigados: o Baque se afogou numa água rasinha de enxurrada... ele estava de chifre cheio... Gervásio sumiu no mundo, sem deixar rasto... Laurindo, a mulher mesma torou a cabeça dele com um machado, uma noite... foi em janeiro do ano passado... Camilo Matias acabou com mal-de-Lázaro... Só quem está sobrando mesmo é o Targino. E o castigo demora, mas não falta...(p. 259).

Manuel Fulô tem um irmão que faz experimentos para tentar sublimar o instinto dos animais. A passagem é curta, mas contém interessante metáfora sobre o processo de civilização, que, para Freud, como vimos, só se torna possível pela sublimação dos instintos de vida e de morte:

Começou por falar-me de um irmão seu, que tinha uma galinha-d'angola domesticada e ensinada, que dormia debaixo do jirau. Não acreditei. Mas pessoas respeitáveis afiançaram o fato, ajuntando que, além da cocar mansinha, o rapaz conservava um rato enjaulado, pretendendo obter que ele e um gato de rajas se fizessem amigos de infância. (p. 264)

O narrador refere-se então aos "subvalentões”, "sedentários de mão pronta e mau gênio, a quem, por garantia, todos gostavam de dar os filhos para batizar” (p. 259), e menciona, como exemplo dessa categoria, o caso de João do Quintiliano, que, embebedado, praticou uma série de atos violentos por ter seu nome mencionado em uma sátira que havia sido deixada em papel pregado numa árvore por autor anônimo. Em suas andanças para descobrir o escritor do desacato, João do Quintiliano chega a Manuel Baptista, o “Aretino do arraial”, que refuta a autoria e ressalta a baixa qualidade do pasquim anônimo; para demonstrar seu talento literário, Manuel Baptista lê para Quintiliano seu último poema, feito para “debochar de muitas atualidades” (p. 260-1):

Essa história de phonetica

eu nunca pude entendê!

É tão feio se assigná

Manuel Batista, sem P!...(p. 261)

A profissão de Manuel Baptista não é especificada, mas pode-se supor que ele seja professor: "Foram atrás dele, para a satisfação, e encontraram-no no paiol do João Italiano, dando escola para os meninos do negociante” (p. 260). A permanência de Manuel Baptista no arraial parece também fazer parte do mesmo projeto educacional em que está envolvido Santana, de Minha gente. Embora seja um professor arcaico, pois reage contra as atualidades da língua, reprime com a arte a violência de João do Quintiliano, o que significa que existe aí um poder, uma força do espírito capaz de conter a violência: “João do Quintiliano ouviu, respeitoso, humilhado pelo poder da arte 
e da ciência. Pediu desculpas e veio reproduzindo, em sentido contrário, a peregrinação suburbana, dando pancada em todo o pessoal com quem antipatizava” (p. 261).

A referência a Virgílio, o Aretino, na passagem que põe em cena Manuel Batista, pode ser uma menção à Divina Comédia, embora tal associação não seja obrigatória. Mas é interessante notar que tal referência pode ser encontrada no Sétimo Círculo do Inferno, o dos violentos - que também será mencionado em A hora e vez de Augusto Matraga, como veremos. O Círculo é guardado pelo Minotauro, "símbolo della violenza bestiale”, nas palavras de Giuseppe Vandelli, que comenta a edição da Commedia da qual nos servimos (ALIGHIERI, 1987, p. 89). O Círculo é dividido em três compartimentos. No terceiro estão penando os violentos contra Deus, contra a natureza e contra as artes. Ali se encontram os blasfemadores, os violentos contra Deus, como Targino: “Esse-um é maligno e está até excomungado... Ele é de uma turma de gente sem-que-fazer, que comeram carne e beberam cachaça na frente da igreja, em sexta-feira da Paixão, só p’ra pirraçar o padre e experimentar a paciência de Deus...” (p. 258-9). O primeiro compartimento é destinado aos violentos contra a vida e os bens do próximo, e nele os Centauros vigiam os penitentes, que cumprem suas penas imersos num rio de sangue fervente. Para Della Giovanna, o Minotauro e os Centauros, que têm em comum a natureza simultaneamente humana e animal, simbolizam as duas principais paixões motrizes da violência, a cobiça e a ira. (ALIGHIERI, 1987, p. 92). Há uma alusão explícita ao centauro em Corpo fechado, quando se faz referência a Manuel Fulô e sua mula Beija-Flor, que "era o orgulho do Manuel Fulô. Mais do que isso, era o seu complemento: juntos, centaurizavam gloriosamente” (p. 264). O próprio sorriso de Manuel Fulô faz que ele se assemelhe a um cavalo: "Manuel Fulô abriu um riso feio avançando os dentes amarelos e grandes, como fieiras de grãos numa espiga de milho tal e qual um cavalo” (p. 281). Sua identificação com a mula e com animais de modo geral é mencionada em outras passagens do conto: "E olha que isso de animal é minha comida: entendo disso direito, sei puxar uma matéria!” (p.267); “o que eu nasci mesmo p’ra saber fazer é negócio de negociar com animal” (p. 268); “Mas olha aqui: sou besta?” (p. 268); “Foi tudo por causa do raio de uma bestagem que eu fiz...” (p. 271); "De tardinha, na hora de pegar a estrada, tocavam, tardos: ele, tonto qual jamais outro, perdia logo a perpendicularidade, e se abraçava ao pescoço da mula, que se extremava em cuidados e atenções” (p. 264-5); “Um coice mal dado chega p’ra desmanchar a igrejinha da gente...” (p. 277). Em outra passagem, ele explica, ao interlocutor, que se veste de acordo com a raça do animal: “...Ô beleza!... Eu saía com a cavalhada, e era 
que nem artista de circo-de-cavalinho! Primeiro, fazia bonito na rua, repassando... Aquilo, eu caprichava comigo: p'ra animal murzelo, eu punha roupa preta, p'ra malhado, paletó d’uma cor, calça doutra...” (p. 269)

A identificação de Manuel Fulô com sua mula se estende aos nomes de ambos: Manuel Fulô e Beija-Flor; e mesmo o nome de sua noiva, Maria das Dores, a “das Dor”, tem semelhança fonética com os nomes do protagonista e de sua mula. O protagonista é descrito pelo narrador com algumas características físicas de animal, como a referência a seu "lobo de orelha", a descrição de seus dentes em fio e malares pontudos como se fossem instrumentos de ataque:

Mas gostava de fechar a cara e roncar voz, todo enfarruscado, para mostrar brabeza, e só por descuido sorria, um sorriso manhoso de dono de hotel. E, em suas feições de caburé insalubre, amigavam-se as marcas do sangue aimoré e do gálico herdado: cabelo preto, corrido, que boi lambeu; dentes de fio em meia-lua; malares pontudos; lobo da orelha aderente; testa curta, fugidia; olhinhos de viés e nariz peba, mongol. (p. 263).

Os animais do conto parecem ter mais virtudes do que muitos seres humanos. As lutas no conto se travam entre homens e não existem aqui descrições de lutas ferozes entre os animais, comuns nos outros contos de Sagarana; a própria mula Beija-Flor parece ser mais virtuosa do que seu dono: “O meu amigo gostava de moças, de cachaça, e de conversar fiado. Mas tinha a Beija-Flor. Ah, essa era mesmo um motivo! Uma besta ruana, de cruz preta no dorso, lisa, vistosa e lustrosa, sábia e mansa - mas só para o dono.” (264). Manuel Fulô ama sua mula tanto quanto à noiva:

- É o jeito. Eu só queria treis coisas só: ter uma sela mexicana, p’ra arrear a BeijaFulô... E ser boticário ou chefe de trem-de-ferro, fardado de boné! Mas isso mesmo é que ainda é mais impossível... A pois, estando vendo que não arranjo nem trem-de-ferro, nem farmácia, nem a sela, me caso... Me caso! seu doutor...(p. 267)

- Oh, Manuel! Você gosta mais é da das Dor ou da Beija-Fulô?

- Me desculpe, seu doutor, mas isto é pergunta que se faça? Gosto das duas por igual, mas primeiro da das Dor!...(p. 282)

Manuel Fulô não é a única personagem associada a animal no conto. Desidério, um antigo valentão, era “cavalo coiceiro”, como vimos. E, na descrição de Maria das Dores, também é mencionada uma característica animal da noiva de Manuel Fulô: "Era uma rapariguinha risonha e redonda, peituda como uma perdiz”. Mas, a associação neste caso se faz entre uma personagem feminina e um pássaro pacífico.

Em um meio que privilegia a força, em detrimento da lei, o valentão pode passar a ser objeto de temor ou admiração, dependendo da forma como emprega e pratica sua valentia. Como a valentia acaba por se tornar um valor, o pusilânime Manuel Fulô 
procura mostrar-se corajoso aos olhos do narrador em vários momentos, como, por exemplo, quando se refere a Targino e diz: "Isto aqui é uma terra terrível, seu doutor... Eu mesmo... O senhor me vê mansinho deste jeito, mas eu fui batizado com água quente...” (p. 259). Ou na passagem em que afirma ser filho natural de Nhô Peixoto: “Raça de gente braba! Eu cá sou assim: estou quieto, não bulo com ninguém... Mas, não venham mexer comigo! porque desfeita eu não levo p'ra casa, e p'ra desaforo grosso a minha Beija-Fulô não dá condução.” (p. 266).

Ele é mestiço, mistura das três frações que compõem a raça brasileira: de caburé - sinônimo de cafuzo -, de aimoré e de gálico; Beija-Flor, por sua condição de mula termo que está na raiz etimológica de “mulato”, uma parcela da composição racial da personagem - é tão híbrida quanto o dono. A hibridez do protagonista e sua duvidosa identidade são reforçadas pela dupla paternidade, por sua assimilação simultânea a cavalo e gente e por seus muitos nomes: "Mas, com o Manuel Veiga - vulgo Manuel Flor, melhormente Mané Fulô, às vêzes Mané das Môças, ou ainda, quando xingado, Mané-minha-égua (...) acostumei-me a tratá-lo de Manuel Fulô, que não deixava de ser uma boa variante.” (p. 263-4). Manuel Fulô é também preguiçoso: “não trabalhava mesmo, de jeito nenhum, e gostaria de saber quem inventou o trabalho, para poder tirar vingança.” (p. 263).

Os ciganos da história são embusteiros e ladrões de cavalos; confirmam a visão negativa que sobre eles se tem normalmente, de espertos e enganadores (p. 268). E Manuel Fulô torna-se tão hábil em tapear compradores, escondendo defeitos de cavalos, que consegue o extraordinário feito de enganar os próprios ciganos, vendendo-lhes por preço maior do que realmente valem, “dois sujeitinhos ordinários de cavalos, que eram mesmo o restolho da porcaria maior de tudo quanto é cavalo ruim que não presta...” (p. 272). As opiniões raciais expressas pelo narrador são as mesmas da sociedade brasileira, e o próprio mestiço Manuel Fulô, como vimos acima, tem preconceito contra o negro Miligido e também contra os ciganos, como é mostrado em muitas passagens do conto; numa delas, ele se refere ao repúdio do povo: “em qualquer parte em que cigano briga, seja lá com quem for, o povo todo do lugar se ajunta e todo o mundo aproveita p’ra dar pancada neles...(p. 276-7). Em uma outra passagem ele se expressa de forma depreciativa sobre os judeus, talvez reproduzindo a linguagem do local: "Nem se ela, Deus a livre guarde, morresse, o que não é bom falar, eu nem o couro não havia de vender p’r'aquele judeu!..” (p. 277). 
Nas vésperas do casamento de Manuel Fulô com Maria das Dores, um diálogo do narrador com o protagonista é interrompido pela chegada do valentão Targino. A figura deste é imediatamente associada a um animal feio como um sapo e feroz como um tigre:

Até que assomou à porta da venda - feio como um defunto vivo, gasturento como faca em nervo, esfriante como um sapo - Sua Excelência o Valentão dos Valentões, Targino e Tal. E foi então que de fato a história começou.

O tigrão derreou o ombro esquerdo, limpou os pés, e riscou reto para nós, com o ar de um criado que vem entregar qualquer coisa. (p. 279).

O valentão avisa que quer dormir com a noiva antes do casamento e que, se houver recusa de seu pedido, matará

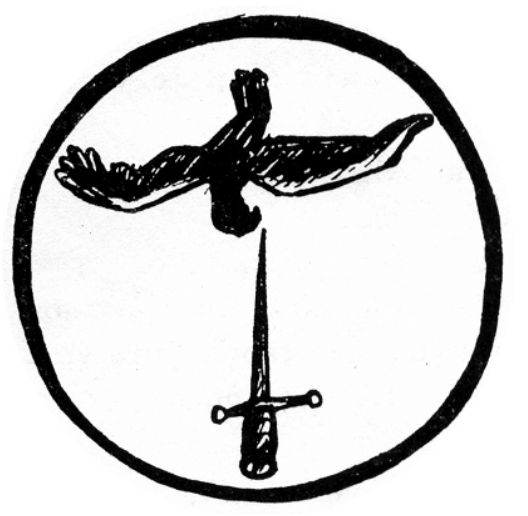
Manuel Fulô (p. 280). A condição aflitiva de Manuel Fulô é expressivamente mostrada na ilustração de Poty da página 292 da $5^{a}$ edição, na qual vemos uma ave mergulhar em direção à ponta de uma espada posta na vertical.

O narrador se assusta com a ameaça do valentão: "Eu perdi o peso do corpo, e estava frio. Me mexia todo, sem querer” (p. 280). Mas, vendo o transtorno de Manuel Fulô por causa da ameaça sofrida, o narrador se propõe a agir: “- Você dorme aqui, Manuel. Eu vou agir...” (p. 280); em seguida faz um discurso eloqüente e solene sobre a necessidade de heroísmo nas circunstâncias do momento: “- Não fazer nada seria uma infâmia... Temos de defender a das Dor! Há momentos em que qualquer um é obrigado a ser herói...” (p. 281). Em Sezão, o grandíloquo discurso intelectual do narrador é ainda mais estranho ao momento, ao local e ao interlocutor:

- Sim. De acordo com todos os precedentes, eis chegado o momento em que o amor deverá transfigurá-lo, galvanizá-lo, convertendo-o num herói...

- Uma ova!

- Mas, e o prestígio do amor?! A bem da história, você...

- Que história, que Mane-história! O senhor está é caçoando comigo (ROSA, J.

G., 1937, p. 253)

Mais adiante, a sugestão do narrador a Manuel Fulô, de usar a violência para conter a violência de Targino, é dada claramente: “- Bem, mas se o sangue de Peixoto é bom mesmo para ferver, você vai preparar as armas, para enfrentar o Targino amanhã, na hora da baderna, não vai?” (p. 281).

Frente ao medo de Manuel Fulô de enfrentar o valentão, o narrador pensa em um ardil para sair da situação: “Mas, você, que logrou até os ciganos, vai me ajudar agora a 
inventar um estratagema, um modo de fintarmos o Targino?” (p. 281). Como essa proposta tampouco é bem recebida pelo atemorizado protagonista, que, como ele mesmo diz, mal consegue "pensar o trivial”, o narrador resolve recorrer ao coronel Melguério. O coronel é a maior autoridade local, mas suficientemente vacilante como mandante para merecer o “coprocrático” apelido de "berda-Merguério":

O Coronel era boa pessoa, só que o chamavam de berda-Merguério. Ouviu, deu de ombros, e indeferiu:

- Se o senhor quiser, pode arranjar quem pegue o Targino à unha, que a autoridade aprova. Agora, gente p’ra isso é que não há por aqui... Ninguém não tem sopro p’ra esse homem... (p. 282)

O narrador recorre então ao vigário, que por ser sua segunda escolha, parece ser a segunda autoridade, vindo logo atrás do coronel: "Então, fui ao Vigário. O reverendo olhou para cima, com um jeito de virgem nua rojada à arena, e prometeu rezar; o que não recusei, porque: dinheiro, carinho e reza, nunca se despreza” (p. 282). Começa então a temer pela própria vida: “E, aí, eu comecei a temer por minha pele própria, e voltei, frouxo, aflito por que passasse o dia, tudo acabasse, e a gente pudesse ver o resto como ia ser” (p. 282-3). O subdelegado - a quem o narrador nem sequer pensa em recorrer, por causa do resultado nulo que espera alcançar em seu pedido de auxílio -, fugira de cena: "saíra do arraial, de madrugadinha, para assunto urgente de capturar, a duas léguas do comércio, um ladrão de cavalos...” (p. 283). A família de Manuel Fulô prefere que este ponha seu destino nas mãos de Deus, que não tome nenhuma atitude e entregue Maria das Dores a Targino (p. 283).

Ante a falta de perspectiva de uma solução para seu problema, só resta ao protagonista apelar para a magia de Antonico das Pedras ou Antonico das Águas. A figura de Antonico, que, de acordo com Manuel Fulô, “Tem partes com o porco-sujo...” (p. 278), é algo parecida com a de João Mangolô, de São Marcos. O feiticeiro fecha o corpo de Manuel Fulô contra arma de fogo do valentão e recebe, em troca, a mula Beija-Flor. Dá-se então o duelo entre Targino e Manuel Fulô, com a morte do valentão.

Na condição de desordem social que reina no local em que Corpo fechado se desenrola, ao homem indefeso frente à ameaça de um valentão que atua no vazio da força das autoridades restam poucas alternativas de sobrevivência: defender com as próprias mãos a sua integridade física, ou seja, combater a violência com a violência, recorrer a Deus ou ao misticismo das religiões ou fazer o pacto com o diabo. 
Escrevendo sobre Grande sertão: veredas, Walnice Nogueira Galvão afirma que religião e violência têm sido, historicamente, as saídas da plebe rural brasileira. (GALVÃO, 1986, p. 81). O temor que o protagonista tem do opositor não lhe permite empregar a força, como sugerido pelo narrador. Também não se efetua a solução por meio do uso de uma estratégia capaz de lograr Targino. Da mesma maneira, são infrutíferas as tentativas do narrador de buscar a solução nas autoridades - solução que nem sequer foi pensada pelo amedrontado Manuel Fulô.

O conto é narrado na primeira pessoa em tom humorístico. O narrador é médico como o autor, mas não é estabelecida no texto qualquer aproximação entre autor implícito e narrador como a que vimos em São Marcos. Ele assiste estupefato aos acontecimentos que se desenrolam no arraial e vai gradativamente apreendendo a realidade do local e alterando os conceitos que trouxera da cidade sobre a vida no sertão. Ao contrário do narrador de São Marcos, que se dedica à contemplação da natureza, o narrador de Corpo fechado, desde o início da narrativa, mostra total desinteresse por essa espécie de assunto. De forma sintomática, no conto não existe uma descrição sequer de paisagens naturais, plantas ou rios. Somente animais e homens, em constantes identificações entre si, são os representantes da natureza; e, mesmo em se tratando de homens, os conhecimentos do narrador são esparsos e limitados (p. 261-2).

O narrador vai ao arraial e descobre uma verdade diferente da que lhe era ensinada no meio do qual procede, e as coisas ali não são exatamente como parecem ser à primeira vista. Esse conceito também está explícito em outras passagens do conto: os ciganos maquiam os animais para vendê-los a preço maior do que realmente valem, e muitas das histórias contadas sobre valentões são fantasiosas, a começar pela própria valentia do pusilânime Manuel Fulô e pelo estatuto de valentão que assumirá no desfecho do conto. A distância entre o que é dito ou pensado e o que é real é mostrada na cantiga de roda que epigrafa Corpo fechado:

A barata diz que tem
sete saias de filó...
E mentira da barata:
ela tem é uma só. (p. 256).

Por ter uma compreensão limitada do funcionamento social do arraial, o médico narrador apresenta soluções inexeqüíveis para auxiliar Manuel Fulô a sair do impasse em que se encontra. Por seu turno, Antonico das Pedras-Águas - curandeiro, portanto, 
concorrente do narrador - soube esperar o dia em que pudesse vestir com a sela mexicana a ambicionada mula Beija-Flor, tirando proveito do beco sem saída em que Manuel Fulô se encontra. Conhece os contendores muito melhor do que o narrador, a ponto de saber que Targino poderá sucumbir frente ao surpreendente destemor de seu oponente, e que Manuel Fulô, acreditando ter o corpo fechado, permitirá que seu ódio cresça a ponto de liquidar o valentão. Suas previsões se realizam.

Os narradores de Corpo fechado e São Marcos são representantes de uma cultura universal - o narrador de Corpo fechado é, possivelmente, poliglota como o autor, pois sabe que "grais” é “cavalo” para os ciganos (p. 274). Mas, enquanto o narrador de São Marcos tenta isolar-se socialmente e se desloca para a contemplação da natureza, o de Corpo fechado empenha-se em assimilar a cultura local e envolve-se ativamente na pendência entre Manuel Fulô e Targino. Como resultado dessas duas formas de narrar, enquanto São Marcos se apresenta como uma meditação sobre motivos conceituais relacionadas à questão da identidade nacional, Corpo fechado trata diretamente de um assunto prático relativo à sociedade brasileira. Em ambos os casos, a ação prática dos dois narradores atinge resultados sofríveis. O primeiro fica cego em seu confronto com Mangolô, e o segundo nada consegue na busca de justiça; além disso, o emprego da ciência tem efeito nulo no confronto particular que ele trava com as crenças locais e com a magia de Antonico das Pedras-Águas.

A solução encontrada por Manuel Fulô para vencer o duelo com Targino entregar a mula para ter o corpo fechado - é um ato heróico que faz dele um ser humano, pois, simbolicamente, ele perde a parte animal de sua dupla natureza - homem e animal, Manuel Fulô e Beija-Flor. Essa perda do lado animal da personalidade do protagonista encontra correspondência no âmbito social com a chegada do destacamento policial ao arraial e a conseqüente extinção da figura do valentão e da violência que ele patrocina. Estabelece-se assim o estado de direito, no qual um novo tipo de valentão, agora de boa paz e mantido somente pela tradição, dá tiros para o ar, usando balas verdadeiras ou de festim. Visto sob essa perspectiva, Corpo fechado apresenta, de um lado, um panorama sobre as conseqüências da ausência de instituições e, de outro, a necessidade do fortalecimento daquelas instituições como terapêutica para a contenção da violência.” (p. 286). 


\section{CONVERSA DE BOIS}

Na carta enviada a João Condé já mencionada, Guimarães Rosa afirma que a trama de Conversa de bois, inicialmente idealizada para Sezão, foi modificada, surgindo outra, "também com carro, bois, carreiro e guia - totalmente diferente da da véspera." (ROSA, J. G., 1984, p. 10), e que “em 1945 sofreu grandes retoques, mas nada recebeu da versão pré-histórica, que fora definitivamente sacrificada.” (ROSA, J. G., 1984, p. 10). Se considerarmos as revisões pelas quais passou, a elaboração final do conto parece ser resultado de muita reflexão, o que pode explicar, em parte, a sua complexidade. O fato de o conto em sua versão final apresentar grandes diferenças em relação àquela que constava em Sezão não impede que lancemos mão da versão original como fonte auxiliar nesta nossa análise, porque, como mostraremos, as mesmas idéias gerais estão contidas nas duas versões, mas, para felicidade do analista, em Sezão elas são expostas mais claramente.

A peculiaridade de Conversa de bois está no foco narrativo: há dois narradores; um deles está oculto e se mostra em uma única passagem:

Estacam todos, bois e carro, no meio do chapadão. Foi o guia Tiãozinho, que teve de parar para segurar as calças, que lhe tinham caído de repente até aos pés. Depôs a vara no chão, depressa, porque estava até vermelho, só em camisão e perninhas magrelas, que vergonha. E agora está-lhe custando para amarrar a tira de pano na cintura e ficar composto outra vez.

Com o céu todo, vista longe e ar claro - da estrada suspensa no planalto - grandes horas do dia e horizonte: campo e terras, várzea, vale, árvores, lajeados, verde e cores, rotas sinuosas e manchas extensas de mato - o sem-fim da paisagem dentro do globo de um olho gigante, azul-espreitante, que esmiúça: posto no dorso da mão da serrania, um brinquedo feito, pequeno, pequeno: engenhoca minúscula de carro, recortado; e um palito de vara segura no corpo de um boneco homem-polegar, em pé, soldado-de-chumbo com lança, plantado, de um lado; e os boizinhos-de-carro de presépio, de caixa de festa. E o menino Tiãozinho, que cresce, na frente, por mágica. Pronto. As calças não vão cair mais!(303).

Sua visão é ampla, completa e pormenorizada. É um narrador onisciente que capta o mundo com um olho gigante, capaz de reduzir as paixões humanas extremas a brincadeira de criança e a comédia, pois essa visão se manifesta justamente quando o menino é apanhado em situação cômica, de calças caídas. O olho se assemelha a um olho maçônico "a magna visão, o divino conhecimento, o Grande Arquiteto do Universo” (SANTOS, 1983, 176). Em nenhum momento de Sagarana a visão de um 
autor implícito onisciente e onipotente é mostrada com tanta clareza como no parágrafo acima.

O outro narrador encarrega-se do restante do conto. Em seu diálogo com Manuel Timborna, ele evidencia a intenção de introduzir modificações e acréscimos na história que lhe é contada pelo interlocutor: “- Só se eu tiver licença de recontar diferente, enfeitado e acrescentado ponto e pouco... (p. 303)”. Isto pode significar várias coisas, mas todas têm um aspecto comum: a narrativa se desenvolverá do ponto de vista particular do segundo narrador e, portanto, os fatos realmente ocorridos serão por ele alterados com o objetivo definido de induzir o leitor a concluir alguma coisa que não fazia parte da história originalmente contada por Timborna, história que, por sua vez, havia sido contada pela irara a Timborna. É de se admitir, então, que cada um dos contadores intermediários tenha interpretado os fatos e introduzido as modificações que mais lhe interessaram, pois não há razão para supor o contrário. Em Sezão, o ponto de vista do segundo narrador é incisivamente declarado já de início, quando ele discursa sobre as leis por ele criadas sobre o modo de entender os animais. É uma passagem longa, mas que vale a pena transcrever por conter uma espécie de roteiro para a interpretação da narrativa:

Absolutamente indisciplinada, a imaginativa de Manuel Timborna é do gênero enguia, espécie gasosa, variedade evasionista. Qualquer assunto, na timbórnica boca, sobe. E pretender reconduzi-lo às honestas planuras do verossímil será qualquer coisa de parecido com as tentativas da gente chamar a si um carretel, puxando pela ponta da linha.

Por isso, e porque suas histórias acabam sempre moendo o pó de canela da dúvida por cima das minhas conviç̧ões mais sérias, é que eu gosto de as escutar. Tanto assim que nelas baseado, me decidi esboçar as leis segundo as quais uma pessoa, inteligente ou estúpida - gradações humanas que aqui, felizmente, nada importam - conseguirá pôr-se mais ou menos em condições de captar quase todos os argumentos, recheados de bom senso, dos suínos de ceva e pescar mesmo qualquer coisinha dos monólogos torturantes de um jaburu metafísico e -1 com o bico, pescoço e cabeça; 2 com o papo e o resto do pescoço; 4 com as pernas cruzadas - matemático.

Exagerando o valor de minha adesão, Manuel Timborna reconheceu prontamente todas as minhas conclusões e esquemas; e, mesmo sem vacilar, passou a dizer que tinham sido a última descoberta sua. De qualquer forma, porém, achando-me abonado pela sua autoridade de inventor do assunto, ninguém terá o direito de me contestar. E eis:

Em primeiro lugar, não é através dos ouvidos que nos chegam os significados da linguagem dos animais; ao contrário - se é que o Timborna é bom observador - esse entendimento parece emergir, do fundo mesmo da gente. 
Depois, só se apanha a parolagem das criações aquilo que de perto se relaciona com os negócios que no momento nos interessam, ou que, pelo menos, nos deveriam interessar; e, mesmo assim, apenas frases soltas, que não as mais importantes: meros fiapos de fala e cimos de conversação.

Ainda mais: no estado atual desta nossa ciência, não obtivemos ainda puxar todoo-mundo às alturas de agüentar tamanhas responsabilidades; e, nisso - que consolação! não levam vantagem nenhuma sobre nós os outros nem os zoólogos e nem os poliglotas. As bestas têm predileções estranhas: fazem-se de melhor grado compreendidas pelas crianças - mas, quando os meninos falam nisso, os grandes se zangam e não lhe dão atenção-; também de preferência fornecem às pessoas tristonhas, que gostam de vaguear sozinhas, e aos loucos - mas esses merecem ainda menor crédito do que os garotos, o que não deixa de ser lamentável, sofrivelmente. (ROSA, J. G. , 1937, p. 24-5)

O fato de ser omitido o ponto 3 dos processos de captação da linguagem dos animais já mostra que algo nos é ocultado; portanto, devemos desconfiar de suas palavras. Essas leis são as que regem o entendimento entre humanos - no caso, entre narrador e leitor - e nos alertam para o fato de que os acontecimentos serão transmitidos em função de interesses, aptidões, hábitos, estados afetivos duradouros ou momentâneos, expectativas e desejos do narrador.

Wayne C. Booth afirma que o termo "narrador” se refere "ao orador da obra que, afinal, não passa de mais um dos elementos criados pelo autor implícito e pode dele ser diferenciado por amplas ironias. “ 'Narrador' é geralmente aceite como o 'eu’ da obra, mas o ‘eu’ raramente, ou mesmo nunca, é idêntico à imagem implícita do artista.” (BOOTH, 1980, p. 90). Pelo contrário, “o narrador é, muitas vezes, radicalmente diferente do autor implícito que o cria.” (BOOTH, 1980, p. 168). Quando analisamos São Marcos mencionamos que, para Booth, na leitura é estabelecido um diálogo implícito entre autor, narrador, os outros personagens e o leitor, e que cada um pode se identificar ou se distanciar dos demais em graus amplamente variáveis. E, discorrendo sobre o narrador onisciente, pergunta se ele é “Digno de quanta confiança? (...) Em que alturas vai ele falar verdade, em que alturas não passará qualquer juízo ou mesmo dirá mentiras?” (BOOTH, 1980, p. 180). Essas considerações de Booth são fundamentais nesta nossa análise. O primeiro narrador identifica-se com o “autor implícito” e assim será designado nesta análise. Ao segundo narrador, pouco fidedigno como se viu, chamaremos simplesmente de "narrador"

Conversa de bois retoma o discurso presente em Minha gente, São Marcos e Corpo fechado, segundo o qual o homem pode cair no estado animal se for guiado pelos 
seus instintos. Em Conversa de bois, os animais se humanizam e alguns homens se mantêm humanos, como acontece com determinadas personagens e com o próprio narrador, enquanto outros se animalizam, como Agenor Soronho e Tiãozinho; e o autor implícito se aproxima do divino porque tudo observa.

Entenda-se que, aqui, animalizar-se significa brutalizar-se, bestializar-se, e que o termo está em oposição a humanizar-se, que é adquirir hábitos sociais civilizados, no terceiro sentido dado por Wolf a que nos referimos na análise de $O$ burrinho pedrês. Em Conversa de bois, porém, a fronteira entre as duas categorias - animal e humana -, mais que estática, é um tanto flutuante, o que aproxima muito a obra do conceito freudiano segundo o qual o homem não tem motivo para se excluir de todo o reino animal.

Em Conversa de bois, as inter-relações entre homens e animais, e mesmo entre os animais, são figuras das relações observáveis no campo social, e analisar tais relações significa tratar das formas de relacionamento entre os vários atores que compõem o corpo social, relacionamento que somente pode ser compreendido se forem levados em consideração os pontos de vista desses vários atores. A irara, os bois, Agenor Soronho, Tiãozinho e o narrador são representantes simbólicos dos vários grupos sociais que atuam dentro do corpo social geral, que é o meio físico no qual o conto se desenrola.

A condição econômica não é, no conto, o fator que determina diretamente os interesses dos vários grupos sociais nem as atitudes de defesa de tais interesses dentro do corpo social. O que motiva os indivíduos a agrupar-se ou isolar-se é a tentativa de escapar à submissão física determinada pelo emprego da violência. A ausência de motivações diretamente econômicas é recorrente em Sagarana, como vimos na análise de $O$ burrinho pedrês, e veremos que também não é a condição econômica das personagens o fator que determina o grau maior ou menor de seu comportamento violento em Conversa de bois. A violência é a espinha dorsal da obra e aqui toda a narrativa se concentra nas ações de atores que praticam a violência e, simultaneamente, tentam escapar de ser a ela submetidos. Estas conclusões, que são extraídas do conto, podem ser associadas às idéias de Pierre Clastres. Em Arqueologia da violência, Clastres propõe uma explicação para a guerra recorrente nas sociedades primitivas, fundindo as idéias de Hobbes e Levi-Strauss. Ele refuta o discurso economista como explicação da guerra afirmando que as sociedades primitivas são as primeiras sociedades de abundância, aquelas que funcionam segundo o princípio: “a cada um conforme suas necessidades" e que, considerando o pequeno tempo dedicado à produção, são “verdadeiras sociedades de lazer.” (CLASTRES, 2004, p. 243-4). 
Se as classes do conto não são especificamente classes econômicas, mas, sobretudo, categorias intelectuais, o relacionamento no meio social fica determinado pelo repertório intelectual de seus membros, e a solução encontrada por essas categorias para se defender da violência ou para justificar o seu emprego depende, em grande parte, desse mesmo repertório (Tiãozinho, por exemplo, pratica a violência contra Soronho, e o narrador, homem culto, utiliza sua competência retórica para justificá-la, como veremos). Como conseqüência, o conto apresenta uma faceta política que pode ser inferida em Sagarana e está especialmente clara em Sezão, referente à luta de classes intelectuais pelo poder. Se considerarmos que o conto está tratando de grupos sociais que tentam se proteger da violência, mesmo que para isso acabem por praticá-la contra outros grupos sociais, na realidade o que se tem é um resgate da discussão teórica em torno da necessidade de conter os impulsos violentos do homem, substituindo-se o poder do indivíduo pelo poder da comunidade - condição essencial para o processo de civilização, como afirmou Freud em $O$ mal estar da civilização. Sob esse enfoque, o conto põe em discussão a comunicação entre classes intelectuais e, por extensão, trata da formação do contrato social. A noção de que o conto trata do relacionamento intelectual entre os homens - por intermédio do relato de relacionamento das várias personagens que entram na história, sejam animais, sejam homens - é textualmente especificada em Sezão: "Manuel Timborna, das Porteirinhas, meu grande intérprete, fiador e propagandista da simpática teoria da possibilidade de intercâmbio intelectual entre homens e outros.” (ROSA, J. G., 1937, p. 25). Essa formulação é intencionalmente ambígua, porque "entre homens e outros" pode significar "entre homens e bichos" ou pode significar "entre homens e outros homens”. A aceitar-se a primeira possibilidade, temos a inclusão do homem no reino animal, o que está de acordo com o pensamento de Freud; a aceitarmos a última interpretação, o conto pode ser uma grande alegoria das relações humanas. Pensamos que o mais provável é que sejam ambas. Estas constatações reforçam uma idéia comum a vários contos de Sagarana, a de que a violência, embora instintiva e pronta a se manifestar inopinadamente no homem mais manso, pode ser controlada pelo intelecto, supondo-se que o intelecto seja empregado na criação de um contrato social capaz de exercer o controle da violência; como nos diz Hobbes, “a razão sugere adequadas normas de paz, em torno das quais os homens podem chegar a acordo” (HOBBES, 1974, p. 81). 
O resumo de alguns dos aspectos de Conversa de bois a que nos referimos até aqui é apresentado na epígrafe: trata-se um coro do Boi Bumbá referente a um boi ameaçador que faz a terra tremer e cujo nome traz conotação de força bruta:

Lá vai! Lá vai! Lá vai!...

- Queremos ver... Queremos ver...

- Lá vai o boi Cala-a-Boca

fazendo a terra tremer!...

(Coro do Boi-Bumbá.) (p. 287)

A epígrafe de Conversa de bois em Sezão era o poema de Manuel Bandeira de “Estrela da manhã”. Nesse poema, é ressaltada a questão do ponto de vista que norteia a comunicação entre os homens, de tal sorte que, para alguém que está sendo preso em um canavial, cada pé de cana é visto como um oficial da justiça:

“Quando me prendero

No canaviá

Cada pé de cana

Era um oficiá”

(Manuel Bandeira, “Trem de Ferro”) (ROSA, J. G., 1937, p. 23)

Nesta nossa interpretação, procuraremos demonstrar proposições que dão unidade à obra. Algumas delas são sugeridas pelo que dissemos até aqui e outras serão demonstradas no decorrer desta análise.

Tratemos de um aspecto contido em Conversa de bois, o da reflexão em torno da luta de categorias intelectuais com o objetivo de alcançar o poder, o que, em Conversa de bois, significa livrar-se da violência de quem está no poder. Em várias passagens do conto fica explícito que o propósito dos bois é livrar-se da violência sem tréguas de Soronho, eliminando-o. No entanto, não está definitivamente excluída a possibilidade de os bois pretenderem eliminar também Tiãozinho:

- O homem está escorregando do chifre-do-carro!... Vai muito pouco de cada vez, mas nós temos a certeza: o homem está pendendo para fora do chifre-do-carro... Se ele cair, morre...

Outra vez, pelo itinerário alternado, de focinho a focinho, é transmitida a visão da guia:

- O bezerro-de-homem quase cai nos buracos... Ele está mesmo dormindo... Daqui a pouco, ele cai... Se ele cair, morre...(p. 318)

A luta de categorias intelectuais, que em Sagarana não é categoricamente visualizada, é explícita em Sezão. Tubagy, o boi que na versão original ocupa a mesma 
posição de Dançador no carro de bois de Sagarana, é o protótipo do político aparentemente revolucionário de esquerda, mas que, de fato, não passa de um ladino agitador oportunista que procura induzir os outros sete bois a matarem Soronho e Zezinho (este é o nome de Tiãozinho em Sezão), valendo-se do argumento de que a morte do carreiro e do menino-guia trará felicidade, pois eliminará a fonte da violência que os castiga. Para tanto, faz aos pares promessas de benefício imediato, impossíveis de cumprir, adotando astuciosas atitudes pacificadoras de contenção da agressividade dos seus companheiros, para evidenciar sua capacidade de comando e de aglutinação social. Ele tem a pretensão de propagar entre os bois confusas idéias políticas de esquerda criadas pelo homem, tendo, portanto, a mesma pretensão de Rodapião personagem ausente em Sezão: igualar-se aos humanos. Tubagy é, no conto, o instaurador da “desordem”. Em oposição a Tubagy, encontramos Cacique, o Canindé de Sagarana, exemplar do cacique político conservador, velho reacionário padrão - ele é o mais velho dos animais que puxam o carro. Otimista, acomodado, com tendência a delator, Cacique fala das regalias generosamente oferecidas pelo homem aos bois e do futuro promissor que está reservado na velhice àqueles que procedam bem durante a vida. Suas idéias, que são também desordenadamente tomadas ao homem, preconizam o retrocesso. Também Realejo é um velho boi reacionário, para quem o mundo está se perdendo por culpa dos jovens. Tubagy, Cacique e Realejo são exemplares típicos dos políticos brasileiros que lutam pelo poder. Mas, tanto Tubagy quanto Cacique se decepcionam com o desenrolar dos acontecimentos: o primeiro, com o resultado de sua “revolução”, que em nada muda as condições dos bois, pois Zezinho é o Agenor Soronho do futuro; e o segundo, pelas ferroadas que recebe do carreiro como retribuição por sua tentativa de conter o ímpeto revolucionário dos demais bois do carro. Mais importante do que ver nessas considerações uma eventual manifestação de ideologia do autor é ver nelas um quadro desanimador da política brasileira: a atuação de uma direita retrógrada e esclerosada e de uma esquerda virulenta sobre uma massa passiva que mais se assemelha a bois de carro - idéias que não conflitam com as expostas em $A$ volta do marido pródigo e Minha gente, os dois contos de Sagarana que tratam especificamente da política partidária.

Em Conversa de bois, Tiãozinho é caracterizado como bondoso e humilde. Mas, no seu projeto de destruir o poder exacerbado de Soronho, mostra-se ambicioso, semelhante a um pequeno ditador, diferente daquele que se vê na maior parte da narrativa: “Quem manda agora na nossa cafua sou eu... Eu, Tiãozinho! ... Sou grande, 
sou dono de muitas terras, com muitos carros de bois, com muitas juntas... Ninguém pode mais nem falar no nome do seu Soronho... Não deixo!... Sou o mais forte de todos... Ninguém pode mandar em mim!... Tiãozão... Tiãozão!” (p. 319-20). Esta passagem mostra, simultaneamente, o objetivo do menino de se livrar da violência do carreiro e sua pretensão de ascensão econômica e social, identificando poder econômico com força física e poder político. Por outro lado, a autoridade física de Soronho sobre o menino é outorgada pela mãe, que "Mandava que ele obedecesse ao Soronho, porque o homem era quem estava sustentando a família toda” (p. 299). Desse modo, a relação conflituosa entre o carreiro e o menino-guia tem também uma conotação de luta de classes econômicas que não pode ser desprezada, embora nos pareça ocupar papel marginal na obra. Os ambiciosos devaneios do menino-guia e as pretensões do boi revolucionário de Sezão não se cumprirão na prática, pelo menos de imediato. A ação de Tiãoznho contra Soronho elimina temporariamente a maldade com que o carreiro o tratava, mas não garante a melhora definitiva da sua vida. De fato, a primeira questão que nos vem à mente é: como Tiãozinho sustentará sua casa, uma vez que eliminou o homem que cumpria essa função econômica?

A figura do boi Tubagy, de Sezão, tem em Sagarana seu correspondente no pensador Rodapião. Este é intelectualmente superior à sua espécie, porque raciocina como homem. É um racional iluminista em busca incessante do conhecimento científico por intermédio do raciocínio analítico. Tanto Rodapião quanto Tubagy pretendem conduzir os outros bois para o rumo que acreditam ser o melhor, propagando sua escala própria de valores e atribuindo-lhe caráter de norma universal - prática herdada do Iluminismo. Mas ambos se darão mal, porque, como diz o sábio moleque Nicanor, de Minha gente, gente é gente e bicho é bicho.

É boi Brilhante quem conta a história do boi Rodapião, “o boi que pensava de homem, o-que-come-de-olho-aberto..." (p. 301), e que "Só falava artes compridas, idéia de homem, coisas que boi nunca conversou” (p. 302). Seu discurso e suas ações são dirigidos pela vontade de dominar o conhecimento científico: “- A gente deve de pensar tudo certo, antes de fazer qualquer coisa. É preciso andar e olhar, p'ra conhecer o pasto bem.” (p. 308). Sua superioridade intelectual em relação aos demais bois emana do seu conhecimento, uma vez que, no Iluminismo, "Poder e conhecimento são sinônimos. (...) O que importa não é aquela satisfação que os homens chamam de verdade, o que importa é a operation, o proceder eficaz” (HORKHEIMER e ADORNO, 
1975, p. 98). Seu conhecimento científico tem função prática: "Sei onde é que não dá tanto mosquito, onde que a sombra, e o limpo do chão; e, pelo jeito do homem, sei muitas vezes o que é que ele vai fazer... Olho p'ra tudo, e sei, toda hora, o que é o melhor...” (p. 308) ${ }^{29}$ e, nesse aspecto, cumpre o preceito segundo o qual “A verdadeira e legítima meta das ciências é a de dotar a vida humana de novos inventos e recursos” (BACON, 1973, p. 55). Seu discurso silogístico, “- Todo boi é bicho. Nós todos somos bois. Então, nós todos somos bichos!..”(p. 306), privilegia a lógica que, ao operar idéias, busca examinar o nexo de subordinação a que estão ligadas; é por meio de um raciocínio lógico que ele tira proveito da atitude do boi Carinhoso: “ - Quando o boi Carinhoso ficou parado, na beirada do valo do pasto, e não quis comer de jeito nenhum, o homem veio e levou o boi Carinhoso no curral, e pôs p'ra ele muito sal, no cocho... Se nós ficarmos também sem comer, todos, parados na beirada do valo, o homem nos dará milho e sal, no curral, no cocho grande...” (p. 308). E se “A lógica formal foi a grande escola de uniformização. Ela ofereceu aos iluministas o esquema da calculabilidade do mundo.” (HORKHEIMER e ADORNO, 1975, p. 100), Rodapião tem a consciência de que a realidade do mundo pode ser medida e calculada, porque consegue estabelecer relações matemáticas entre os atos de pastar e de beber e, com isso, tira proveito sempre que se apresenta uma oportunidade de organizar e racionalizar o tempo ou os movimentos, procurando não desperdiçá-los. Tem pensamento ordenado, vai-se aproximando do pensamento estruturado do homem econômico, que gasta menos tempo e energia para fazer mais:

- Nós temos de pastar o capim, e depois beber água... Invês de ficar pastando o capim num lugar só em volta, longe do córrego, p'ra depois ir beber e voltar, é melhor a gente começar de longe, e ir pastando e caminhando, devagar, sempre em frente... Quando a gente tiver sede, já chegou bem na beira d'água, no lugar de beber; e assim a gente não cansa e tem folga p'ra se poder comer mais! (p. 306)

Ele carrega até mesmo os defeitos dos humanos, como a arrogância - "Vocês não fazem como eu, só porque são bois bobos, que vivem no escuro e nunca sabem porque é que estão fazendo coisa e coisa” (p. 308) - ou a soberba “Eu conheço todos os lugares” (p. 306)

A aplicação de um raciocínio exclusivamente lógico leva Rodapião à ruína. Por confiar desmesuradamente na ciência e no raciocínio dedutivo, supõe conhecer

\footnotetext{
${ }^{29}$ Na terceira edição de Sagarana, o sentido da primeira frase era mais claro: "Sei onde é que não dá tanto mosquito, onde a sombra é melhor e o chão macio” (ROSA, J. G. 1951, p. 286). Essa é uma das várias diferenças das primeiras três edições de Sagarana em relação às posteriores.
} 
perfeitamente todas as coisas, inclusive regiões geográficas desconhecidas e diferentes daquelas com a qual estava habituado. Quando procura água em um morro, comete o erro de deduzir cientificamente que, que por causa das chuvas, o solo estaria firme, quando, na verdade, era de terra solta (p. 311-2). Boi Brilhante, por um raciocínio decorrente da experiência de vida, antevê os riscos da ação de Rodapião: "Eu também olhei p’r’a ladeira, mas nem precisei nem de pensar, p'ra saber que, dali de onde eu estava, tudo era lugar aonde boi não ir. Mas boi Rodapião falou como o homem: - Eu já sei que posso ir por lá, sem medo nenhum” (p. 312). O nome Brilhante lhe é justamente devido porque, embora conhecendo e assimilando o pensamento racional de Rodapião, tem a sabedoria de usar sua intuição no momento apropriado, fruto da experiência, e não confiar na razão, que lhe é estranha, pois própria dos homens. Ele refuta as idéias dos humanos quando afirma “Mas não vamos pensar como o homem...” (p. 294) ou quando diz "Perto do homem, só tem confusão...” (p. 295); a equiparação que os bois fazem entre Rodapião e o homem, como se vê, não significa exatamente um elogio.

A história do boi Rodapião pode ser assimilada ao mito de Ícaro. Diel argumenta que, se as asas construídas por Dédalo têm significado simbólico, Dédalo, o construtor das asas, deve também ter uma significação simbólica. Segundo esse princípio, afirma Diel, “a significação oculta de cada símbolo deve manter relação com uma função psíquica, e Dédalo, o homem engenhoso, só pode estar representando o intelecto.” (DIEL, 1991, p. 50). Diel informa que alguns analistas interpretam o mito como portador da idéia de que o intelecto é capaz apenas de criar asas artificiais e, portanto, a técnica seria um obstáculo para atingir as regiões mais elevadas da vida. Ele refuta essa interpretação, afirmando que a condenação pura e simples do intelecto é inapta à interpretação de um mito, mas que ainda assim essa interpretação sugere a existência de uma forma depravada de intelecto, que estaria na origem do mau uso das invenções técnicas. Portanto, é preciso investigar se os mitos fazem distinção entre uma forma sadia e uma forma perversa do intelecto. Para isso, Diel analisa a figura de Hermes, a divindade que simboliza o intelecto a serviço do espírito simbolizado por Zeus. Suas sandálias aladas significam a força da elevação que constitui uma variante do símbolo central do mito de Dédalo. Mas, paralelamente a essa função de mensageiro de Zeus, Hermes é a divindade que preside o comércio e é também protetor dos ladrões. Ele condensa, portanto, em um só símbolo, as duas formas de intelecto, a sadia e a perversa.

Diel também se refere à vaidade de Ícaro, à qual a de Rodapião se assemelha; e, da mesma forma que o boi rola morro abaixo, caindo vítima dos urubus - "E então 
espiei p'ra baixo e vi que já tinham chegado e estavam chegando desses urubus, uns e muitos.” (p. 312) -, Ícaro cai no mar e se torna vítima de Poseidon:

Ao querer alcançar por meios insuficientes o sol, o espírito, as regiões sublimes, Ícaro afoga-se, engolido pelas regiões submarinas. Perece definitivamente afogando-se no subconsciente do qual, antes de sua temerária tentativa de fuga, já havia sido prisioneiro (no Labirinto). Símbolo do intelecto que se tornou insensato, símbolo também da imaginação perversa, Ícaro é uma personificação mítica da deformação do psiquismo caracterizada pela exaltação sentimental e vaidosa em relação ao espírito. (DIEL, 1991, p. 53-4).

Ao tentar equiparar-se ao ser humano, Rodapião alimenta a mesma intenção de Ícaro e do homem que pretende tornar-se divino, cometendo assim o pecado da soberba, que é exemplarmente punida pelos deuses mitológicos, como nos mitos de Tântalo, Medusa, Faeton, Belarofonte e outros, vindo a tornar-se, não por acaso, um dos pecados capitais do cristianismo. ${ }^{30}$ Dante, nos versos 85 a 96 do canto XXXI, do Inferno fala da condenação de Efialto por sua pretensão de medir forças com Zeus. O uso do intelecto por Rodapião, portanto, assume a forma que Diel caracterizou como perversa.

O caso de Rodapião levanta a mesma questão da qual tratamos em São Marcos quando discorremos sobre o emprego da lógica pelo protagonista-narrador. Por se fazerem conduzir pela razão, Rodapião morre, e o narrador de São Marcos fica cego porque a lógica o impede de acreditar nos poderes de Mangolô e, depois de cego, não consegue, ao empregar o raciocínio lógico científico, sair do mato das Três Águas; no caso de Rodapião podemos ampliar esse conceito e entender seu fracasso também como decorrência do fato de que ele, sendo da classe intelectual dos bois, pretende pensar e agir como membro de uma categoria intelectualmente superior, a dos homens, sem dominar totalmente a maneira de pensar e agir destes últimos. Talvez o apreço de Rosa pela intuição e sua desconfiança na razão tenha origem no reconhecimento da impossibilidade em que se encontra o homem de apreender totalmente um mundo cuja complexidade é maior do que seu entendimento permite alcançar; por isso, o homem possui, "além do cérebro, o sentimento, o coração"

Além do caso do boi Rodapião, em várias outras passagens do conto são assinaladas as diferenças e as similaridades entre homens e animais. Analisemos

\footnotetext{
${ }^{30}$ O próprio Guimarães Rosa cita um exemplo de punição pela soberba em suas anotações sobre a Ilíada: “Thamíris, o Thrácio, gabou-se de que ganharia numa disputa de canto com as próprias musas. Elas se vingaram punindo-o: cegaram-no, tiraram-lhe a dádiva divina do canto, fizeram-no se esquecer o tocar harpa.” (IEB-USP, documento E17).
} 
algumas, que relatam o ponto de vista dos bois a respeito de seus semelhantes e dos humanos:

"Nós somos bois... Bois-de-carro... Os outros, que vêm em manadas, para ficarem um tempo-das-águas pastando na invernada, sem trabalhar, só vivendo e pastando, e vãose embora para deixar lugar aos novos que chegam magros, esses todos não são como nós...”

- Eles não sabem que são bois... - apóia enfim Brabagato, acenando a Capitão com um esticão da orelha esquerda. (p. 292).

A passagem acima sugere que os bois que pastam são inconscientes de sua posição na natureza e, como são exclusivamente guiados por instintos, situam-se na extremidade inferior de uma escala imaginária de categorias intelectuais bovinas, na qual o outro extremo é ocupado por Rodapião. Os bois de carro estão posicionados em um ponto intermediário entre tais limites, porque trabalham e têm consciência de sua condição de seres distintos dos homens. Eles ora se aproximam de um extremo da escala, ora do outro, oscilando entre o estado de selvageria, que se harmoniza com sua natureza, e o estado próximo do humano. De fato, no conto existem diversas passagens em que se mostra tanto a violência própria do animal - “a cada momento, armavam modo de querer chifrar e pisar.” (p. 289) ou “Alguma mutuca voandeja passou e pinicou a orelha de Brabagato, que estava de olhos fechados e atribuiu a ofensa a Capitão. Virou, raivado. Entestam. Reentestam. E estralam as chifrancas” (p. 298) -, quanto a sua mansidão - “Calmos. Bons. Mansos. Bois de paz” (p. 322) -, assumindo comportamento similar ao do boi Calundú, de O burrinho pedrês. Em muitas outras ocasiões os bois quase se humanizam, como nas duas passagens abaixo:

- É engraçado: podemos espiar os homens, os bois outros...

- Pior, pior... Começamos a olhar o medo... o medo grande... e a pressa... O medo é uma pressa que vem de todos os lados, uma pressa sem caminho... É ruim ser boi- decarro. É ruim viver perto dos homens... As coisas ruins são do homem: tristeza, fome, calor - tudo, pensado, é pior...

- Mas, pensar no capinzal, na água fresca, no sono à sombra, é bom... É, melhor do que comer sem pensar. Quando voltarmos, de noite, no pasto, ainda haverá boas touceiras do roxo-miúdo, que não secaram... E mesmo o catingueiro-branco está com as moitas só comidas a meia altura... (p. 294-5)

- Não podemos mais deixar de pensar como o homem... Estamos todos pensando como o homem pensa...(p. 295)

Eles exercem uma atividade produtiva e se referem à prática do trabalho como característica do ser humano - “- E porque temos de viver perto do homem, temos de 
trabalhar... Como os homens... Por que é que tivemos de aprender a pensar?...” (p. 294) -, conceito que se afina com as idéias de Hegel apresentadas em Lições de Iena, segundo as quais o trabalho é o mediador entre o homem e seu mundo (ABBAGNANO, 2000, p. 965); ao mesmo tempo, o trabalho tem para eles conotação muito próxima da que se encontra na Bíblia, em que a luta pelo sustento foi agregada à maldição divina em decorrência do pecado original.

Embora às vezes se assemelhem ao homem, os bois de carro têm idéias confusas, desencontradas e parciais sobre este. Parece-nos que aqui é estabelecida uma relação com as idéias diversificadas do homem sobre Deus, porque em alguns momentos o homem parece representar para os bois aquilo que Deus representa para o homem. Algumas dessas idéias dos bois são acertadas e outras não: “Nem convém espiar muito para o homem. É o único vulto que faz ficar zonzo, de se olhar muito. É comprido demais, para cima, e não cabe todo de uma vez, dentro dos olhos da gente. Mas eu já vi o homem-do-pau-comprido correr de uma vaca...” (p. 292). O boi Dançador conhece uma das mais importantes características humanas, a de apreensão dos objetos com as mãos, graças ao polegar opositor: "o homem pode se ajuntar com as coisas, se encostar nelas, crescer, mudar de forma e de jeito... O homem tem partes mágicas... São as mãos... Eu sei...” (p. 310). Na reação dos bois e de Tiãozinho, após a morte de Soronho, o narrador mostra a moral que nos humanos faz aflorar os sentimentos de culpa no menino, ausentes nos bois:

"Eu tive a culpa... Mas eu estava meio cochilando... Sonhei... Sonhei e gritei... Nem sei o que foi que me assustou...” - Com os bois olhando. Olhando e esperando. Calmos. Bons. Mansos. Bois de paz. E sem atinar com o que fazer. - "Minha Virgem Santíssima que me perdoe!... Meus boizinhos bonitos que me perdoem!... Coitado do seu Agenor!” (p. 322).

O fato de, no estado de natureza, o fisicamente mais forte ter maior possibilidade de subjugar o mais fraco explica a visão que os bois têm dos homens, como seus inferiores: “O homem é um bicho esmochado que não devia haver”, ou seja, é privado de chifres e de armas de defesa. Além disso, como a característica do boi é a calma, ele julga o homem negativamente por causa de sua pressa e de seu medo, como na passagem acima transcrita: “- Pior, pior... Começamos a olhar o medo... o medo grande... e a pressa...” (p. 294). A referência à pressa como atributo negativo do homem é explícita em Grande Sertão, como vimos. Através dos bois, o narrador parece propor 
um projeto pautado na estética e na ética: “É bonito poder pensar, mas só nas coisas bonitas... É isso mesmo... Só o que é bonito... O que é manso e bonito...” (p. 295).

O discurso dos bois é trôpego, entrecortado, com repetições e frases que por vezes se iniciam e não concluem - acenando para a relação que vimos em São Marcos do homem e sua linguagem. Por não entenderem a língua dos humanos, os bois os caracterizam não por seus nomes, mas por suas qualidades: o "homem-do-paucomprido-com-o-marimbondo-na-ponta...” é Agenor Soronho, enquanto Tiãozinho é o "bezerro-de-homem-que-caminha-sempre-na-frente-dos-bois". Esse mesmo procedimento em Sezão é utilizado pelos bois para se referirem aos seus semelhantes (ROSA, J. G., 1937, p. 40).

Se os bois de carro se mantêm entre os bois de pasto e os homens, e se Rodapião procura se aproximar demasiadamente dos homens, Agenor Soronho aproxima-se perigosamente da natureza animal e de seu modelo mítico, o diabo. Os dois últimos encontram a morte violenta como resultado desses comportamentos extremos.

Desde a primeira vez em que aparece, Agenor Soronho se assemelha ao demo, tendo na mão um instrumento que parece apropriado a executar os suplícios físicos impostos aos pecadores do inferno dantesco: "Mas, aí, o carreiro, o Agenor Soronho, homenzão ruivo, de mãos sardentas, muito mal-encarado, passou rente ao papa-mel, que estremeceu, ao ver-se ao alcance do ferrão temperado da vara de carrear” (p. 290); “Aí é que Agenor Soronho está mesmo com o demo” (307). Aparentemente, Soronho só tem uma face, a da maldade, da violência e da agressividade física e verbal; é desmedido, arrogante, invejoso, falso, se rejubila com a desgraça alheia - como no episódio em que, por vaidade de sua reconhecida habilidade profissional, procura humilhar João Bala, carreiro menos dotado (p. 313). Fala muito no diabo e com ele se identifica. Tem os atributos de altura, feiúra e cara vermelha do Satanás descrito por Dante no Canto XXXIV do Inferno, versos 28 a 39:

Do aflito reino o imperador eu via:

Do gelo acima o seio levantava.

A um gigante igualar eu poderia.

(...)

Qual meu espanto há sido em contemplando

Três faces na estranhíssima figura! 
Rubra cor na da frente está mostrando. (Alighieri, Inferno, Canto, XXXIV, 28 -

$39)^{31}$

Soronho não respeita o sagrado, nem sequer o ritual de enterrar os mortos, e traz a desordem ao mundo, tanto para os animais quanto para os humanos. Mesmo seu nome, Agenor Soronho, evoca suas características pejorativas: “Agenor”, etimologicamente, vem do grego Agénos, de ágan (muito), e anér, andrós (homem), e significa muito viril, muito varonil (OLIVER, 2005); o nome tem semelhança fonética com Agni, deus do fogo no hinduísmo (mesma origem que ignus em latim), o que poderia ser uma explicação para o fato de ser ruivo. "Soronho” possivelmente seja contração de "so", senhor, e "ronha”, uma espécie de sarna que ataca as ovelhas e os cavalos, mas que também tem significado de malícia, velhacaria, solência (AULETE).

Ao se aproximar perigosamente da natureza animal, as ações de Soronho são diferentes das do boi Brilhante - que se defende do calor entrando em zonas perigosas do pasto, porém de maneira cautelosa:

Que por isso, ele querer toda vez, no pasto, a sombra das árvores, à borda da mata, zona perigosa, onde mil muruanhas - tavãs e tavoas - tão moscas, voejam, campeando o mole e quente em que desovar. Também que lá, medo ao veneno, a gente tem de pastar com completa cautela: Tubarão, irmão de Brilhante e seu antigo par de junta, morreu, faz mês e meio, ervado de timbó. Coisando por tristes lembranças, decerto, bem faz que Brilhante já carregue luto de-sempre. Mas, perpetuamente às voltas com bernes, bichos, carrapichos, e morcegos, rodoleiros, bicheiras, só no avesso da vida, boas maneiras ele não pode ter. (p. 291).

O pasto aqui pode ser entendido simbolicamente como o meio no qual o homem pode deslocar-se livremente e cujos limites só podem ser atingidos com cuidado e sabedoria. A violência de Soronho é a do indivíduo que vive na "margem do pasto", no limiar da natureza humana, mas não é fruto de sua condição econômica. Ele e João Bala vivem no mesmo meio, têm a mesma profissão, e o paralelo entre os dois homens contém a mesma noção a que já nos referimos, a de que o homem, independente de sua condição econômica, pode se aproximar do mundo por sabedoria, astúcia, cautela e bondade ou por maldade e confronto; a figura de João Bala parece talhada para

\footnotetext{
${ }^{31}$ Lo 'mperador del doloroso regno da mezzo 'l petto uscìa fuor de la ghiaccia; e più con un gigante io mi convegno (...)

Oh quanto parve a me gran maraviglia quand'io vidi tre facce a la sua testa! L'una dinanzi, e quella era vermiglia. (Alighieri, Inferno, Canto, XXXIV, 28 - 39)
} 
contrastar com a de Soronho; ele é bondoso, gosta dos animais e reconhece seu valor; também gosta das pessoas: em suma, vive em harmonia com a natureza. Involuntariamente chama Agenor de “Angenor”, anjo, identificável de imediato com o anjo mau, o diabo. Os bois de João Bala salvam o dono porque são seus amigos, enquanto os de Soronho o matam. João Bala, no entanto, não é esquematicamente bom, e comete os pecadilhos próprios dos humanos; fala "graças a Deus", mas também tem suas fraquezas, como a da cachaça; além disso, fala no diabo, embora muito menos do que Soronho; “Mas, bonito, foi! Foi bonito!... O diabo espatifou lá em baixo” (p. 313). “- Ficou feio, seu Soronho! Ficou feio. Deus e demo, que o carro descambava p’ra trás, feito doido, tinindo e arrastando a junta do coice, que foi a única que ficou presa, com os bois enforcados quase”. (p. 314).

A despeito de tudo o que dissemos, Soronho possui algumas virtudes reconhecidas pela própria personagem que o odeia, Tiãozinho. É Soronho quem sustenta a família do menino, como vimos. E o menino vê sentimentos de bondade no carreiro: “Coitado do seu Agenor!... Era brabo, mas não era mesmo mau-de-todo, não... Tinha coração bom...” (p. 322). Sob este enfoque, é possível que a menção do livro I das Geórgicas, esteja relacionada à injustiça na morte do carreiro: “- Pode que seja, Timborna. Isso não é de hoje:... "Visa sub obscurum noctis pecudesque locutae. Infandum! ...” ”(p. 287). Estes versos, intercalados em uma secção da obra de Virgílio em que são narrados os infaustos acontecimentos que antecedem ao assassínio de César (VIRGILIO, 1999, p. 70), leva-nos a associá-los à morte e à traição de Agenor Soronho e, portanto, à idéia de que seu assassínio é um ato de injustiça.

Como João Bala, a personagem de Tiãozinho se afigura o oposto de Soronho: ele é retratado pelo narrador como um menino piedoso, que trata do pai com carinho. Não transgride as leis da natureza, aproxima-se dos animais com bondade. Sente remorsos pelo ato inconsciente que o levou à vingança, e seu ato consciente é de perdoar Soronho, após a morte deste. Ao se vingar, Tiãozinho pune violência com violência, e dessa forma, se equipara a Soronho, mas, com seu arrependimento, torna-se humano e herói, porque supera a si mesmo e às suas paixões. Ele é carente de pai, de mãe, paupérrimo, desarrumado, em farrapos. A vida que leva deveria transformá-lo em mau; no entanto, é retratado como virtuoso pelo narrador.

Mas, se Soronho não é de todo mau, Tiãozinho também não é essencialmente bom, e as maldades praticadas por ele levam o leitor a considerar a possibilidade de que 
sua mansidão nessa viagem ao arraial decorra mais de sua comoção de momento e de sua idade, do que de traços de caráter. Veja-se, por exemplo, o tratamento que ele dispensa aos bois a fim de mantê-los disciplinados, imitando Soronho:

Oa!... - Dá de-prancha, com a vara, nos topetes dos bois, que desviam para fora os nós dos joelhos, e travam pausa, imóveis perfeitamente. Então o candieiro volta para azeitar o eixo, depois de deixar a vara apoiada no peito da canga - obstáculo esse que Buscapé e Namorado resguardam com respeito.(p. 298)

Quando cutucado por Namorado, reage golpeando a dupla de guia, Namorado e Buscapé. Sua agressão aos bois é uma forma de deslocamento do ódio provocado por suas fantasias sobre os jogos amorosos de Soronho e sua mãe, fantasias essas inspiradas inconscientemente pelo nome do boi, Namorado, e pelos amores de um casal de joãosde-barro, cujo alarido exagerado é interpretado por Tiãozinho como propositais para perturbá-lo:

Um par de joãos-de-barro arruou no caminho, pouco que aos pés de Tiãozinho. Galinhando aos pulos, abrem bico e papo, num esganiço de alarido, mesmo de propósito, com rompante. Arrepicam e voam embora, soprando penas. Marido e mulher.

- Oa, Namorado!... - E Tiãozinho faz meia-volta e dá uma corrida de-costas, pelejando para conter os da guia, golpeando-lhes as testorras e picando-os com o ferrão. Foi Namorado, o boi vermelhengo, que tomou um repente e chegou a catucar o candieiro, com uma cornada de-través. Mas, agora, está pondo olhos mansos, em fito desconsolado, enquanto Buscapé se socorna. (p. 300)

Tiãozinho também, como Soronho, fala do demônio, quando enraivecido, como na passagem abaixo, na qual o leitor menos atento poderá, conduzido pelo narrador, a equivocadamente pensar que a frase “- Ôa!... Ôa, boi teimoso... Buscapé, demônio.” é dita por Soronho:

Fazia medo, tristeza e vergonha, uma vergonha que ele não sabia bem por que, mas que dava vontade na gente de querer pensar em outras coisas... E que impunha, até, ter raiva da mãe...

- Ôa!...Ôa, boi teimoso...Buscapé, demônio.

Ah, da mãe não gostava! ... Era nova e bonita, mas antes não fosse. .. Mãe da gente devia de ser velha, rezando e sendo séria, de outro jeito... Que não tivesse mexida com outro homem nenhum... (p. 299)

Em Sezão, os bois consideram que a mansidão de Zezinho é circunstancial e planejam livrar-se tanto do carreiro como do menino-guia, porque sofrem, em mais de uma ocasião, as conseqüências físicas das descargas da raiva de Zezinho.

Tiãozinho ama o pai, mas odeia Soronho. O ódio que tem pelo carreiro, a esperança de vingança que alimenta, a vontade que tem de matá-lo são constantemente 
repisados no conto. Mas ele também odeia a mãe, porque ela se entrega a Soronho. Ao matar Soronho, amante de sua mãe, para vingar o pai, Tiãozinho reproduz a historia de importantes textos da literatura universal, e o primeiro que nos vem à mente é Hamlet. O ato de Tiãozinho também reproduz o mito de Édipo: este mata o amante da mãe, que exerce a função de pai, pois sustenta a casa e dorme com sua mãe. A estreita relação entre o drama de Shakespeare e a tragédia de Sófocles foi estabelecida por Freud em $A$ interpretação dos sonhos: “Outra das grandes criações da poesia trágica, o Hamlet, de Shakespeare, tem suas raízes no mesmo solo de Oedipus Rex.” (FREUD, 1987, vol 4, p. 259). Mas Tiãozinho e os bois reproduzem também a história da Electra, de Sófocles, na qual Orestes e Electra vingam a morte do pai assassinando a mãe e o amante desta. Tiãozinho não mata a mãe, mas tem ódio dela, o que é confirmado na passagem da página 299: “E que impunha, até, ter raiva da mãe...(...) Ah, da mãe não gostava!...”. Os mitos de Édipo e de Electra podem ser interpretados de forma similar, o que levou Jung a criar a expressão complexo de Electra como a contrapartida feminina do complexo de Édipo. Além dessas referências literárias, a história de Tiãozinho que mata Soronho guarda semelhança também com as narrativas de homens pequenos que matam gigantes, como Ulisses que, com astúcia, matou Polifemo, e Davi, que, guiado por Deus, matou Golias. Para cumprir sua empreitada - uma vingança justa, do seu ponto de vista -, o menino maneja a força bruta dos bois para auxiliá-lo em uma tarefa para cuja execução não teria condições físicas apropriadas. Uma passagem do conto mostra que já pensara em recorrer à violência de animais selvagens para fazer frente e pôr um fim à violência verbal e física do carreiro: "Deixa eu crescer! ... Deixa eu ficar grande! ... Hei de dar conta deste danisco... Se uma cobra picasse seu Soronho... Tem tanta cascavel nos pastos... Tanta urutu, perto de casa... Se uma onça comesse o carreiro, de noite... Um onção grande, da pintada... Que raiva!...” (p. 308)

As associações dos acontecimentos vividos por Tiãozinho com as obras de Sófocles, Shakespeare, Homero e com a Bíblia dão a essa personagem estatuto de herói da alta literatura. E, para completar a associação, ele é descrito como uma criança que amadureceu muito antes do tempo, que raciocina e percebe a vida como adulto e sabe distinguir com clareza os sentimentos da alma humana - como quando consegue ver falsidade nas atitudes da mãe e de Soronho, mesmo em momento de forte carga emocional, o da morte do pai. (p. 304). Mas o menino-guia, aparentemente manso, foi capaz de um assassinato brutal. De maneira similar ao que ocorre em Hamlet e Electra, o assassínio de Agenor Soronho acaba por se tornar, pelo menos aparentemente e para 
quase todos nós, um ato de reparação de injustiça. Porém, em todo o episódio em que é narrada a morte de Soronho, Tiãozinho vai gradualmente se identificando mais e mais com os bois, e essa identificação atinge tal grau, que menino e bois parecem fundir-se num único ser híbrido, com uma única alma. E aqui surge a suspeita de que a mansidão de Tiãozinho é similar à dos bois com quem ele se identifica e, da mesma maneira, sua violência se assemelha à dos bois. São várias as passagens que mostram a simbiose de Tiãozinho e os bois; transcreveremos apenas duas:

- O bezerro-de-homem sabe mais, às vezes... Ele vive muito perto de nós, e ainda é bezerro... Tem horas em que ele fica ainda mais perto de nós... Quando está meio dormindo, pensa quase como nós bois... Ele está lá adiante, e de repente vem até aqui... Se encosta em nós, no escuro... No mato-escuro-de-todos-os-bois... Tenho medo de que ele entenda a nossa conversa... (p. 319)

- Mhú! Hmoung!... Boi... Bezerro-de-homem... Mas, eu sou o boi Capitão! ... Moung!... Não há nenhum boi Capitão... Mas, todos os bois... Não há bezerro-de-homem! ... Todos... Tudo... Tudo é enorme... Eu sou enorme! ... Sou grande e forte... Mais do que seu Agenor Soronho!... Posso vingar meu pai... Meu pai era bom. Ele está morto dentro do carro... Seu Agenor Soronho é o diabo grande... Bate em todos os meninos do mundo... Mas eu sou enorme... Hmou! Hung! ... Mas, não há Tiãozinho! Sou aquele-que- tem-um-anelbranco-ao- redor-das-ventas! ... Não, não, sou o bezerro-de-homem! ... Sou maior do que todos os bois e homens juntos. (p. 319).

Feitas essas considerações, a questão que deve ser respondida é se a violência empregada por Tiãozinho para eliminar a violência bruta e irracional de Soronho é ou não ato de justiça. O que está de fato por trás dessa questão é parte de uma discussão muito mais ampla, a da definição de critérios para julgar se um ato violento, individual ou coletivo, pode ou não ser moralmente justificado.

Do ponto de vista cristão, a resposta tende claramente pela condenação moral do ato do menino-guia, porque a vingança como forma de justiça contraria os preceitos do cristianismo. Mas os vestígios religiosos presentes em Conversa de bois não são suficientemente amplos para caracterizar o conto como história de moralidade cristã; a associação de Soronho ao diabo, por exemplo, se afigura mais como um recurso estético para reforçar a maldade da personagem do que para caracterizá-lo como portador de um sentido religioso. Já do ponto de vista de outras formas religiosas, como a mitologia grega, o comportamento violento de Tiãozinho talvez possa ser mais adequadamente justificado ou condenado - mas isso dependerá da interpretação que quisermos dar ao ato de Orestes e de outras personagens mitológicas. A discussão em torno da moralidade ou amoralidade dos atos violentos dessas personagens literárias e religiosas é 
interminável e, como no caso do crime de Tiãozinho, dependerá do ponto de vista de quem responde à pergunta.

Conversa de bois é o conto dos pontos de vista; a irara, os bois, Agenor Soronho, Tiãozinho, o narrador e o autor implícito têm, sobre a questão da violência, pontos de vista que dependem da sua posição numa escala de intelecto que vai da visão mais simples e restrita, a da irara, até a mais ampla, do autor implícito. Comecemos pela irara, o bichinho que acompanha a história e a conta a Manuel Timborna. É o mais selvagem dos animais da obra, sendo nesse sentido seguida pelos bois que pastam, porque são apenas domesticados, e pelos bois de carro, que são domesticados e trabalham. Para a irara tudo é colorido (p. 288). Ela tem a curiosidade da mulher; observa tudo - "mas, no fundo, não passava de uma mulherzinha teimosa, sempre a suplicar: - Me deixem espiar um pouquinho, que depois eu vou-me embora...” (p. 290) - e, aparentemente, vê pouco e superficialmente: “não podia, nem jeito, admitir que os grandes buracos das rodas fossem os óculos de tirar barro, de dar passagem à lama nos atoladiços: eram, isso sim, ótimas janelas, por onde uma irara espreitar.” (p. 290). Tem um projeto definido em relação aos homens e aos bois que conduzem o carro, mas tal projeto é inacessível ao leitor:

Com um rabeio final, o papa-mel empoou-se e espoou-se nas costas, e andou à roda, muito ligeiro, porque é bem assim que fazem as iraras, para aclarar as idéias, quando apressa tomar qualquer resolução. Girou, corrupiou, pensou, acabou de pensar, e aí correu para a margem direita, sempre arrastando no solo os quartos traseiros, que pesam demais. (p. 288)

Podemos supor que seu projeto esteja relacionado com a vingança que Tiãozinho e os bois executam contra Agenor Soronho, uma vez que essa incógnita tarefa é dada por cumprida no último período do conto: "E logo agora, que a irara Risoleta se lembrou de que tem um sério encontro marcado, duas horas e duas léguas para trás, é que o caminho melhorou” (p. 323). Ela toma um nome tradicionalmente destinado às vacas, Risoleta, mostrando sua afinidade com os bois e, por extensão, com Tiãozinho "E a irara virava a carinha para todas as bandas, tão séria e moça e graciosa, que se fosse mulher só se chamaria Risoleta” (289-90). A dificuldade intelectual que enfrentamos para entender o projeto da irara tem a mesma origem da dificuldade que os homens têm para compreender os bois e vice-versa. Na verdade, a dificuldade para se entender a irara é maior, pois, na escala intelectual, ela está mais distante de nós, humanos leitores. Em Sezão, os homens não só não entendem a irara como também não entendem as 
mulheres, uma vez que, para traduzir a fala dos animais, estas utilizam um sistema diferente do usado pelos homens e talvez mais complexo:

... Mulheres - e aqui Timborna assume tom dogmático e peremptório - nunca dão notícia do mais corriqueiro cochicho de galinheiro: possivelmente terão elas outras, e muito mais tremendas, vias de informação. O único bruto que elas entendem é o papagaio; e, isso mesmo, quando os papagaios articulam em idioma de gente. Do jargão íntimo, esotérico, específico, dos louros e cravos, nada capiscam. Ora, sabendo-se ainda com absoluta certeza, que o senso de humour dos psítacos os leva, só por gaiatice e desfrute, a usar as convenções e cifras - enviezando por exemplo, o rolamento da lingüinha pinulada, refrescando pausas, engrossando tom e timbre, gorgeando ênfases ou esticando vogais para dizerem coisas muito irônicas e positivamente muito diversas de seu significado ortodoxo, compreende-se porque (verifiquem, por favor!) contra todas as boas expectativas e os mais decentes palpites, papagaios e mulheres jamais poderão ser bons amigos de fato. (ROSA, J. G., 1937, p. 25).

A já apontada ostensiva separação entre narrador e autor implícito e o fato de o conto abordar pontos de vista de várias classes intelectuais leva-nos a levantar a hipótese de que suas visões sobre os fatos narrados devam ser também diferentes. Na prática, isto significa que narrador pretende conduzir o leitor por um caminho que o leve a chegar a conclusões diferentes daquelas que ele, leitor, chegaria no caso hipotético de ser informado da interpretação dos fatos diretamente pelo autor implícito, sem o emprego de uma história de ficção que passou por três narradores: uma irara, Timborna e o atual, cada um deles com sua interpretação dos fatos; se os pontos de vista do narrador e do autor implícito fossem idênticos, não seria necessário separá-los de maneira tão clara e incisiva como se faz aqui, a ponto de o narrador se assemelhar a uma personagem. Se o autor implícito se mantém distante da emotiva história contada pelo narrador, sua visão global sugere que os aspectos fragmentários do conto podem e devem ser enfeixados numa perspectiva geral que cabe ao leitor identificar e que deve incluir também o ponto de vista do narrador. Partindo do pressuposto de que o narrador “sempre tem, direta ou indiretamente, um propósito definido” (BENJAMIN, 1975, p. 65), concluímos que o leitor de Conversa de bois deverá enfrentar, de fato, a tarefa de formular uma hipótese interpretativa sobre o conto, que separe o ponto de vista do autor implícito e o do narrador, tentando descobrir qual o propósito do narrador ao relatar os acontecimentos da forma como o faz.

Se nos guiarmos pelas leis que regem o entendimento da linguagem dos animais, enunciadas pelo narrador em Sazão, e suprimirmos tudo o que de inverossímil foi agregado pelo narrador na história de Conversa de bois - bois e iraras não falam -, o 
que cruamente sobra é a história de um vingativo menino-guia que, consciente e propositadamente, aproveita a oportunidade em que um violento carreiro de bois dorme para assassiná-lo. Mas, ao mesmo tempo, o narrador nos dá subsídios para refletir sobre a violência, as justificativas encontradas pelo homem para praticá-la e os meios que encontra para esquivar-se dela. Neste caso, portanto, ao leitor caberá entender os motivos pelos quais um homem culto procura justificar a violência de um menino criminoso, atenuando sua culpa e os traços de seu caráter por intermédio de uma história na qual os bois terminam por ser os verdadeiros culpados pelo assassínio.

O narrador, durante toda a narrativa, acompanha os passos e os pensamentos de Tiãozinho - que pouco fala, enquanto Soronho vocifera raivosamente -, com a intenção de provocar compaixão pelos sofrimentos e sentimentos do menino e levar o leitor a concluir que o crime é, de fato, uma vingança justa. Mas a estratégia usada leva o leitor a imediatamente levantar a questão de quais são os critérios para avaliar quando um ato violento é justo e quando não o é. A resposta a essa questão dependerá do ponto de vista de quem julga, porque, no limite, qualquer ato violento sempre encontrará razões plausíveis para ser justificado - pelo menos de parte de quem o comete -, e poucos admitirão que o perpetraram sem nenhum motivo justo. Os homens mais sanguinários da história antiga, moderna e contemporânea sempre foram e são persuasivos o bastante para justificar as motivações de projetos que levam à disseminação da violência e à aglutinação de milhões de seguidores em torno de suas idéias.

Jorge Luis Borges abordou apropriadamente essa questão do crime justificado ou não. Em El verdugo piadoso, um de seus Nueve ensayos dantescos, Borges faz quatro conjecturas para explicar por que Dante condenou Francesca da Rimini ao Inferno, mas desfalece de dor quando ela lhe conta sua história. Para Borges, a quarta dessas conjecturas é a verdadeira, embora a menos lógica:

La cuarta conjetura es menos precisa. Requiere, para ser entendida, una discusión liminar. Consideremos dos proposiciones: una, los asesinos merecen la pena de muerte; otra, Rodion Raskolnikov merece la pena de muerte. Es indudable que las proposiciones no son sinónimas. Paradójicamente, ello no se debe a que sean concretos los asesinos y abstracto o ilusorio Raskolnikov, sino, a lo contrario. El concepto de asesinos denota una mera generalización; Raskolnikov, para quien ha leído su historia, es un ser verdadero. En la realidad no hay, estrictamente, asesinos; hay individuos a quienes la torpeza de los lenguajes incluye en ese indeterminado conjunto. (Tal es, en último rigor, la tesis nominalista de Roscelín y de Guillermo de Occam.) En otras palabras, quiem há leído la novela de Dostoievsky ha sido, en cierto modo, Raskolnikov y sabe que su "crimen” no es 
libre, pues una red inevitable de circunstancias lo prefijó y lo impuso. El hombre que mató no es um asesino, el hombre que robó no es un ladrón, el hombre que mintió no es un impostor; eso lo saben (mejor dicho, lo sienten) los condenados; por ende, no hay castigo sin injusticia. La ficción jurídica el asesino bien puede merecer la pena de muerte, no el desventurado que asesinó, urgido por su historia pretérita y quizá (...) por la historia del universo. Madame de Staël ha compendiado estos razonamientos en una sentencia famosa: Tout comprendre c'est tout pardonner. (BORGES, 1982, p. 121-2).

Borges conclui dizendo que Dante sentiu "que los actos del hombre son necesarios y que asimismo es necesaria la eternidad, de bienaventuranza o de perdición, que éstos le acarrean.” (BORGES, 1982, p. 123).

Arriscaríamos supor que o narrador de Conversa de bois em muito se assemelha ao Dante que desfalece quando ouve a história de Francesca. Pelo fato de conhecer a história do menino, comove-se e justifica o crime. Mas a pergunta que vem à mente é de como pensará o autor implícito. Admitir que este divirja do narrador é menos estranho do que admitir que ambos pensem da mesma forma. O debate em torno da moralidade contida no crime de Tiãozinho depende do ponto de vista de quem analisa. A personagem de Hamlet, com o qual a de Tiãozinho tem semelhança, é considerada por Goethe, em Os anos de aprendizado de Wilhelm Meister, "um ser belo, puro, nobre, elevadamente moral”, e por Auerbach, em Mimesis, um homem com "uma aura de demonismo" e que "quando algum movimento irrompe dele, este é rápido, audaz e, por vezes, pérfido, e atinge, com violência certeira, o centro do alvo” (AUERBACH, 2001, p. 294). Tiãozinho talvez fosse perdoado por Goethe e condenado por Aurbach.

A hipótese de o autor implícito de Conversa de bois considerar o crime de Tiãozinho como um ato de justiça capaz de eliminar a desordem e instalar a harmonia equivaleria à hipótese de Dante justificar o adultério de Francesca (na verdade, Francesca está no segundo círculo do Inferno, e os assassinos cumprem penas no sétimo círculo; portanto, para Dante o assassínio era um pecado de maior gravidade que o adultério). Mas, embora se compadeça de Francesca, Dante a condena porque, como diz Borges, sente a necessidade de uma justiça que recompense os bons e condene os maus atos dos seres humanos, embora reconhecendo que indivíduos bons e maus ajam por necessidade, mais do que com liberdade. Pode-se argumentar que existem circunstâncias em que um crime de sangue se justifica. No Estado de direito esse ato é justificado quando tem o fim de preservar a própria vida, ou seja, quando é praticado em nome da legítima defesa. Esta sempre encontrou teóricos nos sistemas jurídicos ocidentais. Hobbes, ao enunciar as leis naturais e os contratos no capítulo XIV do 
Leviatã, referiu-se especificamente a essa questão, dizendo que "por todos os meios que pudermos, defenderemos a nós mesmos” (HOBBES, 1974, p. 82). Essa lei, diz o autor, encerra a suma do direito de natureza. ${ }^{32}$ Mas Tiãozinho não mata Soronho em legítima defesa. O que o impulsiona é o ódio pelo amante da mãe. Seu crime é premeditado, portanto passível de punição pelos sistemas judiciários. O narrador nos faz acompanhar todas as ações de Tiãozinho, mostrando-nos predominantemente o ponto de vista do menino, e acaba por nos convencer que um crime por ele praticado foi uma vingança justa. Ainda assim, a despeito do seu empenho, desconfiamos das personalidades de Soronho e do próprio Tiãozinho, bem da interpretação do menino-guia sobre os fatos. E, mesmo admitindo que o narrador tenha apresentado um retrato fidelíssimo sobre o que se passa na mente do menino-guia, fica a questão de como saber da justeza do juízo de alguém sobre um outro a quem tanto odeia. A aplicação prática das conclusões de Borges sobre a ausência de liberdade no ato criminoso liquidaria qualquer possibilidade de um contrato social e levaria à conclusão de que os criminosos de Sagarana - Turíbio Todo, Vinte-e-Um, Alexandre, Targino, etc - não merecem ser condenados por seus atos de violência. Sob essa ótica, desculpar Tiãozinho equivale a desculpar qualquer criminoso - o que, socialmente, significa o retorno ao estado de selvageria. Como afirma Booth, "grande parte da ficção moderna foi escrita partindo do princípio - que, em si, é já um compromisso básico para com um valor - de que compreender tudo é perdoar tudo.” (Booth, 1980. p. 95), repetindo assim a frase de Madame de Staël citada por Borges.

Já se vê que Conversa de bois, por meio de uma ficção dentro da esfera privada, trata de um tema relativo à esfera pública. Ao fazer que o leitor ponha de lado a necessidade da obediência às instituições como exigência fundamental da civilização e julgue com sentimentalismo o crime do menino contado por um narrador persuasivo, o conto mostra um caso prático de aplicação - pelo próprio leitor, habilmente manejado por um narrador astuto - da cordialidade no sentido que Holanda deu ao termo.

O ponto de vista do autor implícito sobre o crime de Tiãozinho é, obviamente, desconhecido, mas sabemos que sua visão é isenta do sentimentalismo dos que estão diretamente envolvidos na história - incluindo-se entre estes, o narrador e o leitor. A isenção de paixões e a distância que mantém do narrador estimula-nos a suspeitar que o

\footnotetext{
${ }^{32}$ O Código Penal brasileiro prevê três situações em que o homicídio não é considerado crime: em estado de necessidade, em legítima defesa e em estrito cumprimento de dever legal ou no exercício regular de direito. O primeiro caso seria, por exemplo, o de dois náufragos disputando o único lugar disponível em um bote. O terceiro é o exercício da força pelo Estado.
} 
autor condena Tiãozinho pela mesma razão que Borges apontou como origem da condenação de Francesca por Dante: o da necessidade de um sistema de punição ou de recompensa pelos atos praticados pelos indivíduos no meio social. O autor implícito seria, portanto, o Dante juiz.

Concluiremos esta análise de Conversa de bois com duas considerações.

A primeira diz respeito à personagem da moça do silhão, que se comove com o sofrimento do menino: “- Pobrezinho do menino!... - exclama a moça do silhão. (...). Mas, agora, a moça do silhão joga uma espiadela e murmura, enojada, qualquer coisa a respeito da falta de escrúpulos de se acondicionarem cadáveres em cima de rapaduras” (p. 293-4). É singular o efeito causado pela humanidade dessa personagem, em um conto encharcado de violência de parte de homens e animais. Ela é uma anomalia no ambiente. Voltamos assim a um aspecto recorrente em Sagarana, o da regra geral da proximidade entre masculinidade e morte e entre feminilidade e vida.

A segunda: a breve análise psicanalítica de Tiãozinho que fizemos acima partiu do pressuposto de que o narrador tenha exatamente captado e transmitido ao leitor os pensamentos do menino com respeito ao pai, à mãe e a Agenor Soronho. Para fazer tal análise, estabelecemos um corte arbitrário entre uma camada narrativa criada pelo narrador para justificar o ato de vingança de Tiãozinho - camada esta que contém somente os acontecimentos envolvendo irara e bois - e outra que contém todos os demais acontecimentos e que, por hipótese, seriam os que o autor implícito, caso se manifestasse, nos relataria como reais. Somente com esse corte arbitrário é que uma análise psicanalítica do menino adquire sentido. O narrador não é confiável e, sem um critério que separe os fatos supostamente reais dos agregados por sua conveniência, analisar psicanaliticamente o menino seria tão disparatado quanto pretender analisar o inconsciente de Diadorim a partir do depoimento de Riobaldo. Por outro lado, o conto comportaria um interessante estudo psicanalítico sobre o narrador para entender as razões que o levaram a justificar o ato de Tiõzinho por meio de uma história complicada, inspirada em clássicos da literatura e envolvendo seres humanos e animais falantes, narrador que, no entanto, comete atos falhos e acaba dando pistas sobre atributos positivos de Soronho e negativos de Tiãozinho, além de confessar a intenção de distorcer os fatos, de acordo com seus interesses. Mas, preferimos restringir nossa atenção ao importante conteúdo social da obra. 


\section{A HORA E VEZ DE AUGUSTO MATRAGA ${ }^{33}$}

Encontramos em A hora e vez de Augusto Matraga alguns dos motivos já mostrados neste trabalho. Na esfera familiar, o conto é o mais bem acabado exemplo da família patriarcal. O sincretismo religioso brasileiro é aprofundado e constitui uma das chaves para a interpretação da obra. O local e o particular se entrelaçam com o universal. A violência e o arbítrio do poder privado são evidenciados com profundidade maior do que em qualquer outro conto de Sagarana. A cordialidade adquire caráter sinistro no combate que fecha o conto. Por outro lado, é o único conto de Sagarana em que o banditismo é apresentando, embora de modo muito menos ostensivo do que em Grande sertão: veredas.

Vários dos seus elementos parecem apontar para uma leitura exclusivamente religiosa e sobretudo cristã, como veremos, mas nesta análise procuraremos demonstrar que Matraga é, na realidade, uma entidade do sincretismo religioso brasileiro e que, embora a religião ocupe um espaço significativo da narrativa, são as idéias sociais que determinam o sentido global do conto.

A vida de Matraga tem sido dividida por alguns analistas, entre os quais Walnice Nogueira Galvão (GALVÃO, 1978) e José Carlos Garbuglio (GARBUGLIO, 2005), em três grandes etapas. Na primeira, ele é mostrado como fazendeiro valentão e libertino, um devasso sem limites nas esferas privada e pública. Como típico representante do mandonismo brasileiro, é a lei e está acima dela. Humilha a própria mulher e a filha com um comportamento social e sexual desregrado, instala a desordem e provoca a infelicidade alheia. No mesmo dia em que sua mulher, Dionóra, o abandona para ir viver com o amante, levando consigo a filha Mimita, ele é espancado pelos seus próprios homens, unidos aos capangas do major Consilva, um de seus muitos inimigos. Em poucas horas torna-se chefe de família sem família, proprietário sem propriedades, comandante sem comandados, macho traído pela mulher, caçador caçado, valentão espancado. Este episódio é caracterizado por extrema violência, por parte do herói e contra ele. Para facilitarmos sua localização na análise, utilizaremos o termo empregado por Galvão e chamaremos a essa etapa da vida do protagonista de pecado, que se

\footnotetext{
${ }^{33}$ Esta análise de A hora e vez de Augusto Matraga é uma versão reduzida e com algumas alterações de nossa dissertação de mestrado em Língua e Literatura Italiana pela Universidade de São Paulo, As múltiplas faces de A hora e vez de Augusto Matraga e suas duas traduções italianas. (BENEDETTI, 2003)
} 
encerra quando Nhô Augusto salta do barranco, escapando da morte que os homens de Consilva lhe reservavam.

No início da segunda etapa, ${ }^{34}$ que Galvão chama de penitência, vemos Nhô Augusto moribundo, sendo socorrido e tratado por um casal de negros velhos. Ele é significativamente confundido pelos capangas de seu inimigo com um bezerro morto, sobre o qual sobrevoam urubus, fato que garante a segurança do refúgio do protagonista. O casal de negros o faz retomar o caminho da religião, do qual se havia desviado na infância. Afastando-se de Murici, como forma de apagar da memória um passado que agora repudia, muda-se para Tombador e ali se lança com toda força à prática de severíssimo ascetismo. Esta segunda etapa, penitência, cobre sete anos, muito mais longa, portanto, que a anterior e a terceira; encerra-se com a decisão de sair pelo mundo em busca de sua "hora e vez".

A etapa seguinte, a que Galvão dá o nome de redenção, vai até o desfecho do conto; nela presenciamos a viagem que o herói empreende a esmo no lombo de um burro, seu reencontro com Joãozinho Bem-Bem e o desentendimento que leva à morte as duas personagens.

A primeira das duas epígrafes dá a idéia geral de como o conto será desenvolvido, remetendo à pobreza e depois à riqueza espirituais que serão experimentadas por Matraga no decorrer de sua vida. Ao mesmo tempo, a cantiga está relacionada com o tema da viagem, recorrente em Sagarana, como temos visto.

“Eu sou pobre, pobre, pobre, vou-me embora, vou-me embora...

Eu sou rica, rica, rica, vou-me embora, daqui!...”

(CANTIGA ANTIGA.) (p. 324)

Em carta de 04/03/65 a Harriet de Onís, o autor assim se referiu sobre essa cantiga:

Trata-se de uma canção de brinquedo de crianças, de roda. Mas utilizei-a pelo simbolismo. Refere-se a Augusto Matraga. Note: nos primeiros dois versos temos sua partida, escondido, com o casal de pretos, fugindo do arraial do Muricy, indo para o norte: Porque tinha caído na mais baixa e terrível situação possível. (...) Depois, nos dois outros versos: a "riqueza” é da alma, de superação, de realização transfiguradora e adequada: "I

\footnotetext{
34 Sobre esta etapa da vida de Matraga, leia-se o excelente ensaio de Garbuglio Sangue, suor e céu (GARBUGLIO, 2005).
} 
am rich, rich, rich” - e por isso mesmo, ele (sua alma / his soul) vai embora daqui (deste mundo); morre, muda-se para plano mais alto (o céu?) (IEB-USP).

No provérbio capiau da segunda epígrafe,

"Sapo não pula por boniteza,

mas porém por percisão."

(PROVÉRBIO CAPIAU.) (p. 324)

existe uma palavra-chave, "percisão”. Sinônimo de necessidade, encontra definição na doutrina filosófica do necessitarismo, “a doutrina que admite o destino, a ordem finalista e providencial do mundo como ordem que determina necessariamente todas as coisas e a cada coisa garante o melhor resultado”. (ABBAGNANO, 2000, p. 709). Como iremos mostrando nesta análise, o leitor é freqüentemente induzido a ver a história desenrolar-se sob o efeito permanente de um destino já definido, sendo a trajetória de Nhô Augusto dirigida por necessidade mais do que com liberdade.

Na frase que abre a obra são apresentados os três nomes do protagonista: “Matraga não é Matraga, não é nada. Matraga é Esteves. Augusto Esteves, filho do Coronel Afonsão Esteves, das Pindaíbas e do Saco-da-Embira.”(p. 324). Gavão afirma que Matraga é nome mítico, Esteves é nome social e Augusto, nome individual (GALVÃO, 1978, p. 63). Ainda na frase introdutória do conto, o narrador fala de "Nhô Augusto - o homem - nessa noitinha de novena” (p. 324). “O homem” indica o poder no campo material e, no âmbito cristão, insinua uma aproximação com o divino, pois Jesus é o Filho do Homem.

Com procissão seguida de reza e reza seguida de leilão atrás da igreja, a "gente de bem” abandona o local. A cena é de muita confusão; alguns procuram em vão manter a religiosidade do evento, a prostituta Angélica é beliscada por todos, vai de mão em mão, surgem brigas, o povo dá louvores a Nhô Augusto, por admirar seu poder econômico e temer sua violência. A prostituta Sariema, posta em leilão, é arrematada por Nhô Augusto; ao dar um lanço dez vezes maior que o de outro pretendente, sem ao menos examinar a prostituta detidamente - o que somente fará mais tarde, quando a expulsará sem piedade -, Nhô Augusto toma duas atitudes opostas às de Jesus, que acolhera e perdoara a prostituta e se indignara com a prática do comércio no Templo.

É em meio à confusão da cena que o narrador nos apresenta uma das passagens mais intrincadas do conto, com uma cantiga cheia de significados.

- É do Nhô Augusto... Nhô Augusto leva a rapariga! - gritava o povo, por ser

barato. E uma voz bem entoada cantou de lá, por cantar:

Mariquinha é como a chuva: 
Boa é, p'ra quem quer bem!

Ela vem sempre de graça,

Só não sei quando ela vem...

Aí o povaréu aclamou, com disciplina e cadência:

- Nhô Augusto leva a Sariema! Nhô Augusto leva a Sariema! (p. 326)

Presos à relação de Nhô Augusto com a prostituta, somos induzidos a dar à expressão "de graça" o sentido de "grátis". No entanto, a leitura mais atenta da passagem mostra que existem na cantiga algumas palavras de conotação religiosa, que aparecem na prece da Ave Maria: "Mariquinha”, diminutivo de Maria, "graça”, e os dois “ave” nos cacófatos "ela vem” do terceiro e do quarto versos. É possível atribuir à "chuva" uma conotação de "graça", se atentarmos para o fato de que a "chuva" somente reaparecerá no momento em que Nhô Augusto perceber que seu sofrimento físico e moral está terminando: "Até que, pouco a pouco, devagarinho, imperceptível, alguma cousa pegou a querer voltar para ele, a crescer-lhe do fundo para fora, sorrateira como a chegada do tempo das águas, que vinha vindo paralela” (p. 347). Sobre esta última passagem, Guimarães Rosa forneceu interessante informação à sua tradutora americana, Harriet de Onís, em carta de 04/03/65: "São duas evoluções cíclicas paralelas: a do mundo interior de Nhô Augusto, subjetiva; e a outra, objetiva, do mundo exterior, que o circunda - a marcha do tempo, das estações do ano” (IEB-USP). A imersão na água é uma forma de purificação e de regeneração - o batismo cristão ratifica essa noção -, porque nela tudo se dissolve, se desintegra e toda a história é suprimida; a passagem do conto mencionada acima ressalta essa função da chuva e sua cessação, com o batismo consumado, é o momento em que nasce um novo homem, com nova identidade: "Mas, afinal, as chuvas cessaram, e deu uma manhã em que Nhô Augusto saiu para o terreiro e desconheceu o mundo" (p. 357).

O mistério que envolve a cena é reforçado pelo sentido dúbio do segundo verso e pelo "lá": além de ser a nota central do sistema acústico musical e indicar uma posição do espaço do qual a cantiga está vindo, o "lá" também significa que a voz não pertence ao mundo de "cá" no qual se encontra o povaréu que responde em ritmo binário: "Nhô Augusto leva a Sariema! Nhô Augusto leva a Sariema!”

O povo canta "Ei, compadre, chegadinho, chegou / Ei, compadre, chega mais um bocadinho!...” (p. 328) e Nhô Augusto dirige-se para casa com a Sariema:

Caminharam para casa. Mas para a casa do Beco do Sem-Ceroula, onde só há três prédios - cada um deles com gramofone tocando, de cornetão à janela - e onde gente séria entra mas não passa. (...) 
E, empurrando a rapariga, que abriu a chorar o choro mais sentido da sua vida, Nhô Augusto desceu a ladeira sozinho - uma ladeira que a gente tinha de descer quase correndo, porque era só cristal e pedra solta.

Lá em baixo, esbarrou com o camarada, que trazia recado de Dona Dionóra: que Nhô Augusto voltasse, ou ao menos desse um pulo até lá - à casa dele, de verdade, na Rua de Cima, - porque ainda havia muito arranjo a ultimar para a viagem, e ela - a mulher, a esposa - tinha uma ou duas coisas por perguntar...(p. 328).

A ação de caminhar com dificuldade pelas pedras para ir à sua casa situada no Beco do Sem-Ceroula remete ao sétimo círculo da Commedia, o destinado aos violentos:

A quebrada descíamos formada

de pedras soltas; cada qual movida,

cedia, em sendo por meus pés calcada. (ALIGHIERI, Inferno, Canto XII, 28-30). ${ }^{35}$

Por meio desta alusão ao Inferno, podemos supor que a frase "Beco do SemCeroula” traz implícita a noção de pessoas nuas, confinadas em um beco, local sem saída. Para se chegar ao local, passa-se por três prédios, cada um com cornetão à janela; os cornetões sugerem o latido de Cérbero:

Latia com três fauces temerosas,

Cérbero, o cão múltiplo e furente,

Contra as turbas submersas, criminosas (ALIGHIERI, Inferno, Canto VI, $13-15)^{36}$

A trombeta, versão erudita do cornetão, era utilizada nas celebrações religiosas gregas e romanas e está fortemente ligada à tradição judaico-cristã, encontrando-se em várias passagens bíblicas, das quais as mais notáveis são as do apocalipse.

Em carta a Harriet de Onís de 04/03/65, Rosa explica a passagem “e onde gente séria entra mas não passa”: “O sentido é este, com tom irônico, ou de humour: as pessoas sérias (ironia, humour) entram nas casas quando vêm ali para esse fim; mas, em outras ocasiões, evitam de passar por aquele beco...” (IEB-USP). No entanto, pode-se ainda aventar a hipótese de que a frase, um decassílabo de arte maior segundo a nomenclatura poética, seja a metamorfose de um decassílabo heróico, "Lasciate ogne speranza, voi ch'intrate” (ALIGHIERI, Inf, Canto III, 9) da Divina Comédia. Essa conexão seria sugerida pela presença do verbo “entrar” em ambas e pelo paralelismo que ressaltamos entre o trecho do conto e a obra de Dante. Se nos inspirarmos nessa

\footnotetext{
${ }^{35}$ Così prendemmo via giù per lo scarco

di quelle pietre, che spesso moviensi sotto i miei piedi per lo novo carco.(ALIGHIERI, Inferno, Canto XII, 28-30).

${ }^{36}$ Cerbero, fiera crudele e diversa,

con tre gole caninamente latra

sovra la gente che quivi è sommersa. (ALIGHIERI, Inferno, Canto VI, 13 a 15).
} 
associação, poderemos também interpretar a frase que abre o conto, "Matraga não é Matraga, não é nada”, como referência ao mesmo verso da Commedia, pois trata-se de um decassílabo com vírgula após a sétima sílaba e com acento na vogal “a” na segunda, na sexta e na décima sílabas, considerando-se uma elisão no primeiro "não é” e um hiato no segundo.

A descida empreendida pelo herói, de enorme significado, como vemos, está em clara contraposição à menção da "Rua de Cima”. O narrador nos comunica que aqui é a casa "de verdade” de Nhô Augusto, ou seja, a casa onde o herói reside com sua família legalmente constituída, portanto verdadeira sob o aspecto social e legal; mas é também a casa onde reside e impera a verdade, e essa é a verdadeira casa de Nhô Augusto, e não o inferno ao qual está descendo. Podemos desta forma encontrar na passagem uma referência a um destino auspicioso que está reservado a Nhô Augusto, ficando assim reforçada a predestinação já contida na cantiga “Mariquinha é como a chuva”.

Tudo o que se afirmou acima sobre esta porção do conto parece ser confirmado pelo primeiro verso da cantiga, "Ei, compadre, chegadinho, chegou”, modificado por Rosa a partir do verso Ei, compadre, chegadinho, chegadinho da canção. A transformação do texto da canção original auxilia a confirmar a conclusão de que fatos importantes chegaram, isto é, começaram a ser desencadeados a partir do leilão atrás da igreja.

O narrador afasta-se de Nhô Augusto e focaliza Dionóra, sua esposa, e Mimita, a sua filha. Na sua viagem ao Morro Azul se dá o encontro dela com seu amante Ovídio Moura:

E, quando chegaram no pilão-d'água do Mendonça, onde tem uma encruzilhada, e o camarada viu que os outros iam tomando o caminho da direita, estugou o cavalo e ainda gritou, para corrigir:

- Volta para trás, minha patroa, que o caminho por aí é outro! (p. 331)

Se supusermos que o narrador, como Dante, identifica o caminho para a direita com o do purgatório e do paraíso, poderemos concluir que Dionóra, em sua fuga com Ovídio, afasta-se do inferno que lhe reservava a continuação do convívio com o marido.

As conotações que o adultério feminino tem no ambiente social e geográfico da narrativa são de um crime severamente condenado não só pela religião, mas também oficialmente pela sociedade, o que justifica a absolvição dos chamados crimes de lavagem da honra, em que o marido traído pune com a morte a adúltera e seu amante. 
Portanto, os violentos impulsos de vingança de Nhô Augusto perante o adultério da esposa estão em conformidade com o cenário do conto, mas em contraste com o perdão que dá à mulher e à filha imediatamente antes de morrer. Tal oposição mostra a completa assimilação dos ensinamentos de Cristo que se opera durante a narrativa, no qual o herói abandona a lei dos homens e perdoa simultaneamente a adúltera Dionóra e a prostituta Mimita.

A surra que Nhô Augusto recebe dos homens do major Consilva e de seus próprios ex-capangas (os mais zelos executantes de tal tarefa) é revestida de enorme violência: "Puxaram e arrastaram Nhô Augusto pelo atalho do rancho do Barranco, que ficou sendo um caminho de pragas e judiação.” (p. 335). O sentido antigo do verbo “judiar” é o de "maltratar um judeu” e, em sentido figurado, "maltratar qualquer pessoa”, e “praga” significa “imprecação de males contra alguém” (AULETE); dessa forma, “caminho de pragas e judiação” é um caminho em que um judeu é maltratado e pessoas imprecam contra alguém, o que pode ser, de um lado, uma referência à Via Crucis de Jesus e, de outro, o ritual de malhação de Judas, em que um boneco de pano que representa o apóstolo traidor é atacado a porretadas, pedradas e queimado no sábado de Aleluia:

Já os porretes caíam em cima do cavaleiro, que nem pinotes de matrinchãs na rede. Pauladas na cabeça, nos ombros, nas coxas. Nhô Augusto desdeu o corpo e caiu. Ainda se ajoelhou em terra, querendo firmar-se nas mãos, mas isso só lhe serviu para poder ver as caras horríveis dos seus próprios bate-paus, e, no meio deles, o capiauzinho mongo que amava a mulher-atoa Sariema. (p. 334)

(...) E, seguro por mãos e pés, torcido aos pulsos dos capangas, urrava e berrava, e estrebuchava tanto, que a roupa se estraçalhava, e o corpo parecia querer partir-se em dois, pela metade da barriga. Desprendeu-se, por uma vez. Mas outros dos homens desceram os porretes. Nhô Augusto ficou estendido, de-bruços, com a cara encostada no chão. (p. 335).

O tom ritualístico da malhação é mais bem caracterizado em Sezão, graças ao humor da narrativa: "Puseram Nhô Augusto no meio da roda e começaram com grande judiação, a qual constava de vários números, como, por exemplo, cada um bater por sua vez, ou os vários cacetes a um só tempo.” (ROSA, J. G., 1937, p. 409).

Durante o episódio, “O capiauzinho da testa peluda cantou, mal-entoado: Sou como a ema, que tem penas e não voa...” (p. 335). “Ema” guarda evidente similaridade fonética com Sariema, e este fato, associado ao canto mal entoado do capiau, faz estabelecer uma relação de contraposição e, simultaneamente, de complemento, entre o atual momento e aquele, anterior, em que a cantiga era executada em voz "bem- 
entoada” ("Mariquinha é como a chuva”, etc.), havendo, pois, estreita relação entre a cena do leilão na igreja e a do espancamento de Nhô Augusto, como se na segunda se estivesse iniciando o processo de expiação dos atos cometidos na primeira.

Nhô Augusto é, então, ferretado com a marca de gado do Major, um triângulo inscrito numa circunferência. Essa marca foi objeto de minucioso e definitivo estudo por parte de Walnice Nogueira Galvão (GALVÃO, 1978). A autora ressalta que o triângulo eqüilátero é figura de perfeição. De ponta para cima representa o princípio masculino, de ponta para baixo, o feminino; se sobrepostos, como na estrela de Davi, a união dos dois princípios. Antigo símbolo ternário, o triângulo pode ser a resultante da tensão entre o positivo e o negativo, entre a natureza divina, humana e natural do universo, entre pai, mãe e filho na família, entre corpo, mente e espírito, e assim por diante. No caso de Matraga, seu significado é claramente cristão, pois o triângulo é o sinal representativo da Santíssima Trindade, a união do Pai, do Filho e do Espírito Santo numa só pessoa. A circunferência e o círculo significam, em todas as religiões e em todas as seitas esotéricas, na Cabala e na Alquimia, conceitos amplos e abstratos como a eternidade, a divindade e a perfeição, alguns dos quais compartilhados com o triângulo. O círculo está presente na estrutura circular da narrativa - a personagem sai e volta para o mesmo local -, indicando que Matraga é predestinado e cumprirá o que estava previsto em sua marca. Por outro lado, o triângulo é simbolizado no conto pelas referências ao número três: a personagem central tem três nomes, Nhô Augusto é parte de trios de personagens em vários momentos: com a Sariema e o capiau por ela apaixonado, com Dionóra e Mimita, com o casal de negros, com Joãozinho Bem-Bem e o velho no desfecho do conto, e assim por diante. A inscrição do triângulo dentro do círculo deve ter uma ligação com o destino de Matraga. Galvão distingue a marca de ignomínia da marca de pertença, ressaltando que a origem dos ferimentos de Cristo constitui o exemplo de transformação da marca ignominiosa em marca de pertença; da mesma forma, Matraga transforma a marca de ignomínia em marca de pertença. Delineia a autora dois tipos fundamentais de santos, o santo-asceta, como São Francisco, e o santo-guerreiro, como São Domingos e Santo Inácio de Loyola; os esforços para ser asceta contrariam a índole de Matraga, pois é um guerreiro, e é como guerreiro que se tornará santo; de certo modo, Matraga tem em sua formação, opostos em tensão, um princípio masculino, o pai, e um princípio feminino, a avó rezadeira; igualdade na oposição e oposição na igualdade podem ser encontradas na marca de Matraga, pois o triângulo e o círculo têm estatuto igual e oposto: ambos são figuras 
primárias da geometria plana, porém o triângulo possui o número mínimo de lados para constituir uma figura geométrica, enquanto o círculo representa, no limite, um polígono de número infinito de lados. A trilogia mística de iniciação - morte, renascimento e vida - reaparece na forma cristã de pecado, penitência e redenção ou na de inferno, purgatório e paraíso. A autora afirma ainda que a semelhança da vida de Matraga com a de Cristo vai se acentuando à medida que o conto se aproxima do fim, chegando mesmo a ser chamado de "O Homem do Jumento". No desfecho, experimenta a alegria do mártir que reconhece que a integração com Deus passa pelo sacrifício do corpo.

Dessas importantíssimas considerações de Galvão, poderíamos selecionar três aspectos como os mais significativos para a leitura que estamos propondo. O primeiro é que a marca de Matraga é o sinal indicativo da sua predestinação; o segundo, que o herói vai gradualmente se identificando com Cristo à medida que a narrativa avança; o terceiro, que a marca é indicativa de opostos em tensão, igualdade na oposição e oposição na igualdade.

Na frase "Mas Nhô Augusto se mordia, já no meio de sua missa, vermelho e feroz” (p. 333) está contida a noção de que as ações de Nhô Augusto se realizam por necessidade. O autor afirma que a expressão é “original”, em carta de 04/03/65 a Onís:

Já no meio de sua missa=: Porque a "missa" é uma execução que, uma vez começada, não se pode interromper. A expressão é original, não se trata de coisa usada, comum. Temos de achar eqüivalente ou deixar “mass”. But Nhô Augusto, gnarling, himself, red and furious, was already more than half-way through his Mass. (IEB-USP).

Em latim, o termo "missa” é substantivação do feminino de "missus”, particípio passado do verbo “mittere”, “enviar” ou “despedir”. A expressão "no meio de sua missa” pode ter, portanto, a conotação de no meio de seu envio ou no meio de sua despedida, indicando que a mudança que ocorrerá na vida de Nhô Augusto já está se processando e é irreversível. ${ }^{37}$ Portanto, a expressão “no meio de sua missa” está relacionada ao cumprimento do destino de Nhô Augusto (a frase poderia ser traduzida como “E Nhô Augusto, já em vias de se despedir, se mordia vermelho e feroz”).

Após cumprirem sua tarefa, os capangas de Consilva se retiram: "E deram as costas, sob um sol mais próximo e maior”, ou seja, o sol é o espectador supremo da cena. O sol é mencionado nada menos de dez vezes na obra. É possível entendê-lo como símbolo cristão recorrendo a Ruysbroeck, freqüentemente referido por Guimarães

\footnotetext{
${ }^{37}$ Segundo Smith a antiga liturgia continha duas fórmulas de despedida: a primeira, que ocorria antes da Eucaristia, destinada às pessoas interessadas no cristianismo, mas ainda não batizadas; e a segunda, depois da Eucaristia, para os cristãos já iniciados (SMITH, s/d, p. 331)
} 
Rosa, quer em entrevistas, quer nas epígrafes dos livros que compõem Corpo de baile. Heloísa Vilhena de Araújo transcreve um trecho de $O$ ornamento do casamento espiritual, em que o autor flamengo identifica Cristo ao sol (ARAÚJO, 1996, p. 432-3). Desta forma, podemos interpretar que tudo o que está sucedendo com Nhô Augusto naquele momento recebe o olhar vigilante e onipotente de Cristo, o sol.

Após ser espancado e saltar do alto de um barranco, Nhô Augusto é recolhido e tratado por Quitéria e Serapião, mais tarde definidos pelo narrador como samaritanos (p. 340), comparando os cuidados que ambos dispensam a Nhô Augusto com a ajuda do bom samaritano ao homem despojado de seus bens por ladrões e equiparando a segregação social que o casal sofre, por serem negros e pobres, com a segregação sofrida pelos samaritanos. A violência da primeira etapa dá lugar ao afeto que une o casal de negros ao herói. A velocidade dos acontecimentos e a estridência daquela etapa são substituídas pelo ritmo lento, pelo silêncio e pelo sussurro, soando como o adagio de uma sinfonia, em contraste com o allegro barbaro da primeira etapa. O conto como que adormece, conforme sugerido pela cantiga de Quitéria: “As árvores do Mato Bento / Deitam no chão p’ra dormir.” (p. 337). Tudo se passa como se a vida de Nhô Augusto recomeçasse da origem e renascesse para uma nova jornada. Repassa a infância religiosa, porque havia sido criado pela avó, que “Queria o menino p’ra padre... Rezar, rezar o tempo todo, santimônia e ladainha...” (p. 331) e vai gradualmente, mas não sem dolorosos retrocessos eventuais, de uma vida de sofrimento não só físico, mas principalmente mental - em que é assediado por dúvidas, incertezas, medos e remorsos -, para uma vida de perfeição espiritual e moral.

O padre a quem Nhô Augusto se confessa exorta-o às práticas preconizadas por São Bento em sua Regula Monachorum: “Ora et labora”, oração transformada em trabalho e trabalho em oração. Por ser mencionada em livros de orações, ${ }^{38}$ a jaculatória ensinada pelo padre a Matraga induz o leitor a concluir que a expressão "páginas adiante” é uma indicação adicional de que o conto pode ser interpretado como um texto religioso:

- Modere esse mau gênio: faça de conta que ele é um poldro bravo, e que você é mais mandante do que ele... peça a Deus assim, com esta jaculatória: “Jesus, manso e humilde de coração, fazei meu coração semelhante ao vosso...”

E, páginas adiante o padre se portou ainda mais excelentemente porque era mesmo uma brava criatura. (p. 339).

\footnotetext{
${ }^{38}$ A jaculatória do padre pode ser encontrada sob o título jaculatórias preciosas em EDUARDO, 1959, p. 14
} 
As palavras do padre e a firme decisão de segui-las faz Matraga mudar-se para Tombador com o casal de negros, no rumo norte; no conto, os termos "norte" e "sul" são mencionados seis vezes cada um, sempre relacionadas a Matraga e a Joãozinho Bem-Bem; “leste” e “oeste” não aparecem no conto, e apenas uma vez é mencionado “noroeste”. Esquematicamente, Nhô Augusto percorre uma trajetória que, partindo do sul, de Murici, se dirige para o norte, Tombador, e retorna ao sul, Rala-Coco. Joãozinho Bem-Bem, por outro lado, encaminha-se diretamente do norte para o sul. Vimos que, de modo geral, em Sagarana o norte, de onde Joãozinho Bem-Bem provém, tem uma simbologia ligada ao mal, à morte.

A viagem do trio de Murici a Tombador assemelha-se ao episódio bíblico da fuga para o Egito (Mateus, 2, 13-15), uma vez que tanto Jesus e seus pais terrenos quanto Matraga e seus pais adotivos se afastam de seus locais de nascimento para fugirem de um homem poderoso - Herodes e Consilva, respectivamente - e, dessa forma, ficarem aptos para a execução do empreendimento que o futuro lhes reserva. No momento de partir, Nhô Augusto pronuncia a sentença: "P’ra o céu eu vou, nem que seja a porrete!...”, que repetirá sempre que assaltado por sentimentos que poderiam pôr em risco sua salvação. A crença de Guimarães Rosa no poder da palavra, a que nos referimos quando analisamos São Marcos, explica a invocação constante da frase que o transformará e o salvará.

Em Tombador, Matraga será humilde e manso, como um seguidor fiel das recomendações do padre: “Capinava para si e para os vizinhos do seu fogo, no querer de repartir, dando de amor o que possuísse. E só pedia, pois, serviço para fazer, e pouca ou nenhuma conversa.” (p. 341). Referindo-se a essa passagem, o autor, em carta a Harriet de Onís de 04/03/65, reforça o argumento de que o conto tem características de um evangelho: "De seu fogo =: of his hearth. (observe que, nesta segunda parte da estória, a linguagem assume, freqüentemente, um tom bíblico ou arcaico, arcaizante. Isto é importante).” (IEB-USP). Os preceitos ascéticos da Regula são seguidos com rigor por Matraga. Sua humildade o faz inverter os valores normais de uma sociedade racista e classista, e ele, senhor branco, serve o humilde casal de negros. Quando se considera a maneira radical pela qual era abordada a questão racial no mundo, na época da escrita da obra, a atitude de Matraga de adotar como pais o casal de negros adquire maior significado: “o negro e a negra eram agora pai e mãe de Nhô Augusto.” (p. 343). No vocábulo “agora” está implícito que Matraga se desligou de seus pais de sangue e 
adotou outros, com os quais se ligava pela fé - condição que remete à passagem bíblica de Mateus, 12, 48-49.

Graças ao estímulo do casal, Matraga vai encontrando alegria em sua nova vida de penitente. Ocorre neste ponto o aparecimento de Tião da Thereza em Tombador, a primeira das grandes tentações a que será submetido o herói. Tião traz notícias de Dionóra, que está vivendo muito bem com o amante, e de Mimita, que, seduzida por um mascate, se tornou prostituta. E relata que Quim Recadeiro, acreditando que seu patrão havia sido morto pelos homens de Consilva, enfrentou os jagunços do major e foi assassinado por eles. É uma dura prova para Nhô Augusto - acrescida que vem pela expressão de nojo e de desprezo de Tião da Thereza frente à condição a que se reduziu o poderoso e temido Nhô Augusto Esteves das Pindaíbas -, que o faz titubear em sua virtude. Como o leiloeiro da Igreja de Muricy e o vaqueiro Tião da Thereza têm o mesmo nome, estabelece-se uma relação causal entre dois acontecimentos distantes no tempo e no espaço: de um lado, a cantiga "Mariquinha é como a chuva, etc.”, que prevê a chegada da graça

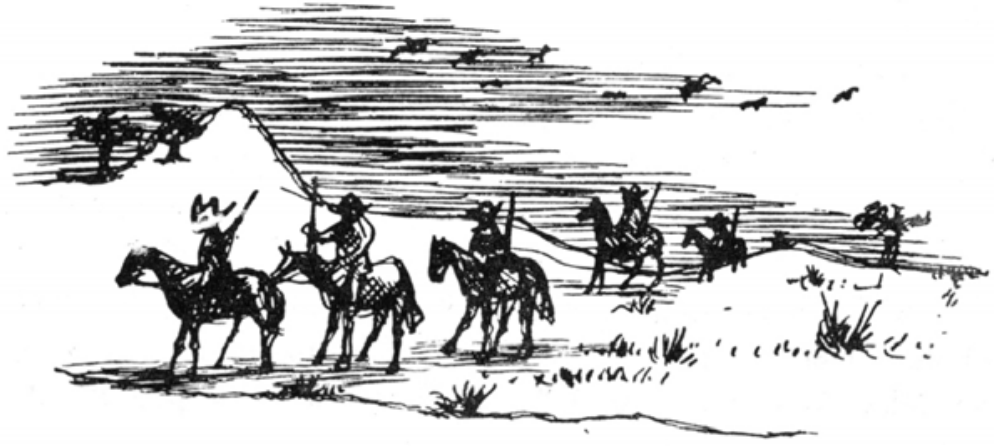
com as chuvas e é entoada na ocasião em que Nhô Augusto dá rédeas a seus instintos, e, de outro, a situação oposta, em que o herói luta desesperadamente para conter os instintos que o levarão à conquista da graça, que será anunciada pela chuva em poucos meses. Este aspecto premonitório pode ser visto na ilustração da página 357 da $5^{a}$. edição. Acima do horizonte vemos um grupo de pássaros, todos rumando para a mesma direção, da direita para a esquerda do quadro; na porção inferior da ilustração há cinco cavaleiros armados. Na página anterior é narrada a marcha de Matraga rumo ao norte junto com o casal de negros, a chegada dos três a Tombador e a vida cotidiana de Matraga; na página na qual está a ilustração, tem continuidade a narrativa da vida diária de Matraga e, no fim dessa página, é contada a passagem de Tião da Thereza por Tombador. Examinando o vôo dos pássaros dessa ilustração, ocorre de imediato associá-lo ao vôo dos pássaros narrado nas páginas 357 e 358 da 15ª edição, imediatamente antes da partida de Matraga montado no jumento. Por outro lado, o grupo de homens armados, da parte inferior do desenho de Poty, traz à mente o bando 
de Joãozinho Bem-Bem, pelo fato de esse ser o único grupo de homens em armas a aparecer no conto (não existe polícia em A hora e vez de Augusto Matraga).

As aves em bando movem-se na mesma direção na ilustração, o que também ocorre no conto: tanto as aves e o bando de Joãozinho Bem-Bem rumam para o sul. Sob esse prisma de interpretação, conclui-se que a ilustração, inserida antes do correspondente momento narrado, tem a conotação de premonição da chegada de Joãozinho Bem-Bem a Tombador e da viagem a esmo de Matraga sobre o burrinho, inspirada pelo vôo das maitacas; por conseguinte, denota que a vontade divina está dirigindo os passos das personagens. De fato, o primeiro encontro de Matraga com Joãozinho Bem-Bem, logo após a chegada das chuvas, ocorre somente meses depois da passagem de Tião da Tereza. Ele se realiza em circunstâncias que parecem seguir um destino definido; Joãozinho Bem-Bem narra que chegou a Tombador casualmente, e o desvio de sua rota parece encerrar o mesmo mistério que cerca a chegada de Matraga a Rala-Côco sobre o jumento:

- A gente não ia passar, porque eu nem sabia que aqui tinha este comercinho... Nosso caminho era outro. Mas de uma banda do rio tinha a maleita, e da outra está reinando bexiga da brava... E falaram também numa soldadesca, que vem lá da Diamantina... Por isso a gente deu tanta volta. (p. 351).

Por seu turno, Nhô Augusto vinha do mato "carregando um feixe de lenha para um homem chamado Tobias da Venda.” (p. 349), quando ficou sabendo da chegada de Joãozinho Bem-Bem ao povoado. Se atribuirmos ao vocábulo "venda” o sentido de “faixa de cobrir os olhos”, podemos relacionar “Tobias da Venda” ao Livro de Tobias do Velho Testamento, em que é narrada a cura da sua cegueira pelo arcanjo Rafael; desse modo, nesse episódio, a chegada de Joãozinho Bem-Bem estaria para Nhô Augusto como a do anjo Rafael esteve para Tobias.

Os convites de Joãozinho Bem-Bem para que Matraga se junte ao seu bando são as outras tentações a que é submetido o protagonista; assemelham-se às tentações de Cristo pelo diabo no deserto, conforme Mateus 4, 1-11: “- Mas comigo é que o senhor havia de dar sorte! Quer se amadrinhar com meu povo? Quer vir junto?” (p. 354). Em Rala-Coco, Joãozinho Bem-Bem reitera o convite a Nhô Augusto e oferece as armas do Juruminho: “- Não se ofenda, mano velho, deixe eu dizer: eu havia de gostar, se o senhor quisesse vir comigo, para o norte...” (p. 364), na tentativa de fazer o protagonista retroceder na direção de tudo o que o norte representa. Logo depois, vemos Nhô Agusto titubear e falar em tentação: "Nho Augusto bateu a mão na winchester, do jeito com que 
um gato poria a pata num passarinho. Alisou coronha e cano. E os seus dedos tremiam, porque essa estava sendo a maior das suas tentações.” (p 365).

Cessam as chuvas, o herói está capinando, quando percebe que "desconhece o mundo”. O sol, que tanto o castigara, agora adquire suprema beleza e se harmoniza com toda a natureza. A manhã é cheia de alegria, surgem, ruidosas e alegres, as maitacas com a incumbência de indicar-lhe o caminho a seguir, rumo ao sul; surgem as maracanãs, os periquitos e mais e mais maitacas, todos brotando do norte e rumando para o sul. Ao mesmo tempo em que passam as aves, passa uma rapariga bonita, não porque essa seja especialmente bonita, mas porque todas as mulheres são bonitas, como os anjos. Ao entoar a canção que entoa do capiau exilado, inspirada na rapariga que se afasta, como as aves, ele adquire a consciência de que está fora de seu lugar. Abandona a mãe Quitéria e o pai Serapião para cumprir o seu destino, montado num jumento, “um animalzinho assim meio sagrado, muito misturado às passagens da vida de Jesus.” (p. 359). Parte, então, como um guerreiro para a luta, entoando a canção que havia sido cantada pelos homens de Joãozinho Bem-Bem, quando também partiam de Tombador.

Em sua viagem sobre o burrinho, Matraga experimenta o êxtase com as cores da natureza, com os animais insignificantes, em tudo vê poesia e prodígio. E, em uma das passagens mais obscuras do conto, encontra um velho com um bode:

Uma tarde, cruzou, em pleno chapadão, com um bode amarelo e preto, preso por uma corda e puxando, na ponta da corda, um cego, esguio e meio maluco. Parou, e o cego foi declamando lenta e mole melopéia:

“Eu já vi um gato ler

e um grilo sentar escola,

nas asas de uma ema

jogar-se o jogo da bola,

dar louvores ao macaco.

Só me falta ver agora

acender vela sem pavio,

correr p'ra cima a água do rio,

o sol a tremer com frio

e a lua tomar tabaco!...”

- Eh, zoeira! 'Tou também... - aplaudiu Nhô Augusto. Já o cego estendia a mão, com a sacola:

(...)

E explicou: tinha um menino-guia, mas esse-um havia mais de um mês que escapulira; e teria roubado também o bode, se o bode não tivesse berrado e ele não investisse de porrete. Agora, era aquele bicho de duas cores quem escolhia o caminho... 
Sabia, sim, sabia tudo! Ótimo para - guiar... Companheiro de lei, que nem gente, que nem pessoa de sua família...

Se despediu. Achava a vida muito boa, e ia para a Bahia, de volta para o Caitité, porque quando era menino tinha nascido lá.

- Pois eu estou indo para a banda de onde você veio... Em todo o caso, meu compadre cego por destino de Deus, em todo o caso, dá lembrança minha a todos do povo da sua terra, toda essa gente certa, que eu não tenho ocasião de conhecer!

E aí o jumento andou, e Nhô Augusto ainda deu um eco, para o cerrado ouvir:

- “Qualquer paixão me adiverte...” Oh coisa boa a gente andar solto, sem obrigação nenhuma e bem com Deus!...(p. 361-2)

“Matraga” tem semelhança fônica com o termo francês “matraque”, sinônimo de “porrete”, que aparece na frase repetida pelo herói. Por outro lado, Walnice Nogueira Galvão associou a palavra Matraga com “trágos” (bode em grego), que também está na raiz da palavra “tragédia”, esta última, literalmente, “canto do bode”. A figura do bode que conduz o cego cria instigador entrelaçamento entre Matraga, bode e porrete.

O bode amarelo e preto é a figura central desta passagem, porque é o primeiro a ser visto por Nhô Augusto; em seguida é vista a corda e, em sua ponta, o cego. A simbologia ligada ao bode é ampla e ambígua, mas no cristianismo ele é a imagem da luxúria e da impureza, totalmente absorvido na sua necessidade de procriar; na Idade Média, era a representação do diabo. Ele possui as duas cores, amarelo e preto, da luz e da sombra. O cego, a despeito de sua cegueira, já viu - ou tem a pretensão de ter visto coisas que ninguém vê, e presume que verá outras coisas que também nunca ninguém viu ou verá; e na sua melopéia menciona a "ema”, como a lembrar Nhô Augusto da Sariema e da cantiga mal-entoada pelo capiau por ela apaixonado.

Em sua vida de pecado, Nhô Augusto orientou-se por falsas verdades e, como o cego, acreditou estar vendo coisas que não poderia ver e prevendo que veria o que nunca poderá ser visto. A Bíblia possui um sem-número de passagens em que "cego” e “cegueira” denotam cegueira espiritual. Nhô Augusto, na sua vida pecaminosa, não enxergava o perigo que corria sua alma e é esta a sua cegueira. Todavia, a cegueira é também freqüentemente associada à luz interior, à sabedoria e à vidência - pense-se em Tirésias -, à capacidade de ver o que os outros não podem ver.

A despeito da ambivalência da representação da figura do bode e da cegueira, podemos, sob a perspectiva religiosa, efetuar uma interpretação desta passagem: a de que a caminhada que o cego está empreendendo rumo ao norte é uma imagem retrospectiva da vida pregressa de pecados de Matraga, vida que o estava levando à 
perdição; e que sua presente caminhada está em contraposição com a viagem do cego. Ambos são conduzidos por um destino que se apresenta com duas formas opostas, porém poderosas: um bode assimilado ao diabo e um jegue que lembra a vida de Jesus. Matraga está próximo de Deus e não se pergunta sobre seu destino, apenas afirma “Qualquer paixão me adiverte...”. (p. 362). Tal alegria é mais bem entendida se dermos ao termo "paixão” o sentido de Paixão de Cristo.

Após o encontro com o cego, Matraga continua sua caminhada até Rala-Côco, perto de Murici, de onde partira sete anos antes; ali reencontra Joãozinho Bem-Bem, que está pronto a executar uma terrível vingança contra a família daquele que assassinara à traição Juruminho, um de seus homens. Em vão Matraga tenta persuadi-lo a não levar a cabo sua desforra. O desentendimento entre os dois homens leva a uma luta, cujo desfecho é a morte dos dois contendores. As associações de Matraga com Jesus nesta parte de conto são evidentes em diversos momentos, até o final: na interferência de Matraga, que se dá logo depois que o velho chama a "força de Deus" (p.366) contra Bem-Bem; na narrativa da luta - "Porque não havia mais balas, e seu Joãozinho Bem-Bem mais o Homem do Jumento tinham rodado cá para fora da casa.” (p. 368); quando o povo diz "Foi Deus quem mandou esse homem no jumento, por mór de salvar as famílias da gente!...” (p. 369); ou quando o velho diz “ - Traz meus filhos, para agradecerem a ele, para beijarem os pés dele... Não deixem este santo morrer assim...” (p. 370).

O desfecho do conto - dois homens que morrem felizes um pela mão do outro constitui, sem sombra de dúvida, a passagem mais significativa e difícil de interpretar. À luz de um modelo de religiosidade dualística cristã, a interpretação desse desfecho adquiriria sentido se Matraga representasse o bem, e Joãozinho Bem-Bem, o mal. Nesse caso, A hora e vez de Augusto Matraga seria a narrativa da luta do bem, Matraga, contra o mal, Joãozinho Bem-Bem. A fraqueza dessa interpretação reside no fato de que ela não é sequer coerente com o conceito da salvação cristã, pois parte do pressuposto de que a salvação de alguém não é conseqüência de seus bons atos em vida nem da observância da palavra de Deus, mas depende da eliminação física de um pecador representante do mal. Em nenhum momento dos evangelhos essa hipótese é sequer insinuada; pelo contrário, propaga-se o perdão e o amor. Mas, além disso, separar o bem do mal de modo claro e definitivo na obra do autor significa caminhar em sentido inverso ao daquilo que se depreende de seus textos e de muitos intérpretes de sua obra. O raciocínio de Finazzi-Agró sobre a questão do bem e do mal em Grande sertão: 
veredas não deixa de ser igualmente válido para Sagarana: “afirmar, por exemplo, que Grande sertão: veredas é o espaço textual de uma luta entre o Bem e o Mal, entre o Deus e o seu Antagonista, significa apenas propor a obra na sua emaranhada, “barroca” simplicidade.” (FINAZZI-AGRÓ, 2001, p. 43). O sacrifício pessoal de Matraga morrer e matar um homem por quem tinha sólida afeição - só tem sentido se sua finalidade for salvar a alma desse homem. Por outro lado, Joãozinho Bem-Bem tem virtudes que parecem fazê-lo merecedor da graça: é crente em Deus, como se pode depreender de suas falas no curso da narrativa, declara afeição pelo seu matador, fato que por si já justificaria sua salvação. Sua intenção é implantar a ordem e a justiça - à sua maneira, é verdade - através de regras éticas solidamente incorporadas. Entendendo-se dessa forma o desfecho do conto, a salvação de Joãozinho Bem-Bem por Matraga é apontada quando o pecado, simbolizado pelas cobras, é expulso de dentro do cangaceiro esfaqueado (p. 368). ${ }^{39}$

A dificuldade de interpretar a morte feliz e simultânea dos dois homens aumenta quando procuramos compreender se as personagens agem com liberdade ou por necessidade. Neste caso, incorremos no controvertido tema do livre-arbítrio, do qual se ocuparam tantos pensadores. Segundo as perspectivas dos preceitos cristãos de santo Agostinho, os destinos de Matraga e Joãozinho Bem-Bem estão previamente determinados. Matraga recebeu a graça divina e, embora de passado pecaminoso, ganha a salvação. Bem-Bem, por outro lado, não recebe a graça divina e pratica o mal, mesmo quando pretende praticar o bem e a justiça e levar a ordem ao sertão. O que Joãozinho Bem-Bem pensa de si mesmo está expresso em suas constantes referências a questões como lealdade e justiça ajustados a uma realidade social que exalta valores de coragem e valentia. Na ausência de um aparato de justiça legalmente constituído, Joãozinho Bem-Bem ocupa a lacuna: "Gente minha só mata as mortes que eu mando, e morte que eu mando é só morte legal!” (p. 351). A frase final de Matraga, “Fala com a Dionóra

\footnotetext{
${ }^{39}$ A simbologia da serpente é espantosamente vasta e diversificada e aparece na maioria das culturas. Tomada como figuração do mal, é apresentada em vários pontos da obra, como, por exemplo, "estão dizendo que o senhor nunca respeitou filha dos outros nem mulher casada, e mais que é que nem cobra má, que quem vê tem de matar por obrigação..." (p. 333), ou ainda: "mas este homem deve de ser ruim feito cascavel barreada em buraco" (p. 337). Na Divina Comédia a serpente é muitas vezes citada no Inferno em associação às criaturas portadoras dos horrores que fustigam os condenados e na tradição judaico-cristã, está fundamentalmente ligada ao mal. É o símbolo do engano, chegando a ser identificada com o próprio Satanás sedutor, a "antiga serpente" do Apocalipse de São João (12:9, 20:2). Em Bicho máu, sexto conto de Sezão e que não foi reproduzido em Sagarana, o narrador menciona uma variedade de símbolos associada à serpente e diz que "A serpente devia ser mesmo diferente, não era um animal como os outros...” (ROSA, J. G., 1937, p. 213-14)
} 
que está tudo em ordem!”, teria o sentido de dizer que não só perdoa a mulher, mas tudo está arranjado, posto em ordem, por Deus em seu devido lugar (o próprio autor se refere à importância desse sentido ao orientar Harriet de Onís, em carta de 04/03/65, sobre o modo de traduzir a frase: "Que está tudo em ordem: - That everything is as it should be.” [IEB-USP]). Se, por outro lado, admitirmos que as duas personagens agem com liberdade, seremos impelidos a afirmar que, à medida que Matraga se aproxima de Deus, Bem-Bem se afasta; de fato, Bem-Bem fala de Deus em três momentos do seu primeiro encontro com Nhô Augusto, enquanto no segundo não $\mathrm{O}$ menciona. No diálogo entre os dois homens, já em Rala-Coco, em sua última tentativa de convencer Matraga a incorporar-se a seu bando, Joãozinho Bem-Bem irrita-se pela primeira vez em todo o conto: “- Que-o-quê! Essa mania de rezar é que está lhe perdendo... O senhor não é padre nem frade, pra isso; é algum?... Cantoria de igreja, dando em cabeça fraca, desgoverna qualquer valente... Bobajada!...” (p. 364). No entanto, a condenação de Bem-Bem ainda assim fica em aberto, pois não faz parte da narrativa o que quer que o cangaceiro tenha dito e sentido antes de morrer: ele pode ter-se preocupado apenas com sua vida que se esvaía, pode ter-se voltado para Deus diante da morte iminente, ou pode mesmo ter morrido imprecando contra Deus e o mundo. O fato de Joãozinho Bem-Bem fazer sua caminhada do norte para o sul, das trevas para a luz, onde encontrará a morte, faz aumentar a incerteza de sua condenação; mesmo porque a possibilidade da sua salvação está contida nas palavras de Matraga, “- Pára com essa matinada, cambada de gente herege!... E depois enterrem bem direitinho o corpo, com muito respeito e em chão sagrado, que esse aí é o meu parente seu Joãozinho BemBem!” (p. 370). Estas palavras dão estatuto idêntico aos dois homens, de modo que, se atribuirmos a Matraga a condição de santo, poderemos supor que também Joãozinho Bem-Bem o seja.

Poderíamos fazer outras conjecturas em torno do duelo final entre os dois homens, mas podem-se perceber as indefinições que decorrem da leitura do conto sob a perspectiva cristã. Outros elementos presentes no texto tornam ainda mais problemática a interpretação cristã da obra, como veremos a seguir.

Voltemos ao já citado parágrafo inicial do conto; nele, "Matraga” é mencionado por três vezes, da mesma forma que "Verbo" na gênese de Cristo, no evangelho de São João. Em Sagarana, as asserções acerca da identidade de Matraga ora são negativas (“MATRAGA não é Matraga, não é nada”), ora se encadeiam em contradição aparente 
(“Matraga é Esteves”), ora se complementam apositivamente (“Augusto Esteves, filho do Coronel Afonsão Esteves, das Pindaíbas e do Saco-da-Embira”), ora assumem caráter alternativo (“Ou Nhô Augusto - o homem - nessa noitinha de novena num leilão de atrás de igreja, no arraial da Virgem Nossa Senhora das Dores do Córrego do Muricí.”), tudo num só período. Desse modo se constrói, lapidarmente, uma pluralidade de caracteres em torno de uma única identidade, tal como, aliás, no Evangelho, em que Jesus é Cristo, é o filho do Homem, é o Nazareno, é o rei dos judeus; em que, aliás, João Batista é também Elias etc. Porém, enquanto o evangelho contém certezas, o período inicial do conto contém apenas dúvidas, o que já sinaliza sua ambigüidade em contraposição às certezas do livro sagrado. Acreditamos estar aí uma primeira evidência da impropriedade de rotular o conto de cristão. Essas três primeiras frases do conto que contrariam os três princípios lógicos fundamentais (v. São Marcos) - mostram a ambigüidade da personagem de Matraga, porque ele é e não é simultaneamente: Matraga é Estêves, portanto, Matraga é. Além disso, Matraga não é nada, que pode ser entendido de duas formas opostas: Matraga é nulo, é nada ou Matraga não é um nada, é algo, ou seja, ele é. O conteúdo paradoxal da introdução do conto pode ser sintetizado na frase de Riobaldo, “Tudo é e não é”, ou nas próprias palavras do autor na carta de 27/01/63 a Joaquim de Montezuma de Carvalho, já referida na análise de São Marcos. Pensamos que podemos aplicar para A hora e vez de Augusto Matraga a noção de Walnice Nogueira Galvão sobre Grande sertão: veredas, de que “A ambigüidade, princípio organizador deste romance, atravessa todos os seus níveis: tudo se passa como se ora fosse ora não fosse, as coisas às vezes são às vezes não são.” (GALVÃO, 1986, p. 13).

A mesma ambigüidade pode ser observada em Joãozinho Bem-Bem. As cobras que saem das suas entranhas quando esfaqueado por Matraga é símbolo expressivo do bem e do mal em diversas culturas; portanto, a narrativa utiliza um símbolo dúbio para fornecer indícios duvidosos sobre a personagem. Para tentar lançar alguma luz sobre a figura de Joãozinho Bem-Bem será necessário, como veremos no transcorrer desta análise, recorrer a Riobaldo; sem suas contribuições, que são recados preciosos para o leitor de Sagarana, a compreensão da figura de Bem-Bem seria tarefa dificílima, pois sua permanência relativamente breve em cena esconde a relevância de seu papel no conto. É Riobaldo quem dá pistas ao leitor de Sagarana da dificuldade de compreender Bem-Bem, em sua primeira referência à personagem: "Seu Joãozinho Bem-Bem (...) ninguém nunca pode decifrar como ele por dentro consistia” (ROSA, J. G., 1956, p. 
18). Ambigüidade pode ser vista também em sua origem; quando Nhô Augusto lhe pergunta se é mineiro, responde: “- Isso sim, que sou... Sou da beira do rio... Sei lá de onde é que sou?!...” (p. 352). Tal indefinição, que põe em dúvida até mesmo sua ascendência mineira, é a mesma da abertura do conto com respeito a Matraga: Joãozinho Bem-Bem é mineiro (afirmação), é da beira do rio (indefinição, pois o rio nasce em Minas Gerais e passa por outros quatro Estados) e não sabe de onde é (segunda afirmação, oposta à primeira). Porém, embora ele próprio desconheça sua origem, em Grande Sertão: Veredas, surpreendentemente, encontramos uma referência ao local de seu nascimento: “Joãozinho Bem-Bem, das Aroeiras”. (ROSA, J. G., 1958, p. 130). Dentre as várias formas de aroeira, as mais conhecidas são a aroeira braba ou branca e a aroeira mansa ou preta; pode ser que o termo "aroeiras”, no caso, tenha sido utilizado para associar sua origem a duas características opostas do caráter da personagem, mansidão e brabeza. Dessa forma, Aroeira indicaria não só o nome do local de origem de Joãozinho Bem-Bem, mas também sua ambivalência.

Uma certa feminilidade da personagem, que suscita dúvidas sobre sua identidade sexual, também está implícita na narrativa de sua chegada a Tombador:

Vindos do norte, da fronteira velha-de-guerra, bem montados, bem enroupados, bem apessoados, chegaram uns oito homens (...) O bando desfilou em formação espaçada, o chefe no meio. E o chefe - o mais forte e o mais alto de todos, com um lenço azul enrolado no chapéu de couro, com dentes brancos limados em acume, de olhar dominador e tosse rosnada, mas sorriso bonito e mansinho de moça - era o homem mais afamado dos dois sertões do rio (p. 348).

O narrador se refere ao número de membros do bando como de "uns oito homens”, o que indica a possibilidade de um deles ser de identidade sexual indefinida. Outro indício é encontrado no episódio em que ele diz ao pai do assassino de Juruminho que não se interessa por mulheres: "E as moças... Para mim não quero nenhuma, que mulher não me enfraquece” (p. 366). Em Grande Sertão: Veredas encontramos uma passagem que reforça a dúvida sobre a identidade sexual da personagem: "Mas Diadorim dava como exemplo a regra de ferro de Joãozinho Bem-Bem - o sempre sem mulher, mas valente em qualquer praça.” (ROSA, J. G., 1956, p. 191). Esse aspecto duvidoso da sexualidade de Bem-Bem pode também ser justificado pela prática costumeira da castidade, por cangaceiros e jagunços, como forma de manter a coragem. É oportuno mencionar aqui um trecho de carta enviada em 11/10/66 pelo autor a seu tradutor alemão, a propósito da tradução americana do conto, em que aborda o comportamento sexual de Bem-Bem: 
O que Joãozinho Bem-Bem quer dizer é que não quer mulheres para si, porque isso põe o homem fraco. Trata-se de crença e prática de alguns jagunços, que praticam a castidade, para não se debilitarem ou não perderem a força anímica e a coragem. Como se vê, o ponto é importante. Não se trata de não gostar de mulheres, ou falta de virilidade, como a tradução deixa supor. Ao contrário, o que o jagunço pretende é ser um Parsifal, um homem forte, mais forte que os outros, acima e independente das atrações debilitantes do sexo. (IEB-USP).

Não podemos estar totalmente seguros de que a explicação acima de Rosa seja a única por ele mesmo considerada viável; além disso, é difícil saber quanto dessa abstinência de cangaceiros e jagunços é forma socialmente aceitável de esconder uma sexualidade problemática no meio social em que predomina a macheza.

A referência que Rosa faz a Parsifal na carta a Meyer-Clason pode ter sido uma forma de exemplificar o seu raciocínio a um alemão, para quem o drama musical Parsifal supostamente deveria ser familiar; no entanto, o assunto passaria a ter interesse desde que o autor realmente tivesse estabelecido, de modo intencional, alguma forma de relação entre a personagem da ópera de Wagner e a de Joãozinho Bem-Bem. As leituras do Parsifal admitem interpretações várias: desde a meramente cristã até o eminentemente simbólica. Isto porque Wagner, a despeito de sua obstinada prolixidade, foi parcimonioso na oferta de elementos que permitissem ao leitor restringir as possibilidades interpretativas dos poemas de seus dramas musicais (característica, aliás, também de Guimarães Rosa em seus textos). O interesse pelo estudo da história, das lendas, da mitologia e da cultura clássicas são pontos comuns entre Wagner e Rosa, e a visão religiosa do compositor alemão guarda interessantes relações com a do escritor mineiro. Embora Parsifal possa ser inserido no âmbito da fé cristã, as complexas idéias de Wagner (tal como as de Rosa) provêm de religiões mais antigas, e em seus dramas musicais encontramos uma profusão de idéias místicas e elementos cristãos e mitológicos. Das lendas, Wagner só extrai o que lhe interessa, acrescentando, por outro lado, um grande número de invenções pessoais. ${ }^{40}$ Discorrendo sobre a aspiração do infinito em Wagner - aspiração também compartilhada por Rosa, como vimos em São Marcos -, Sonia Heinrich de Mattos diz que “A aspiração do infinito através do livre contacto com a natureza identificava-se, naturalmente, com a volta aos tempos antigos,

\footnotetext{
${ }^{40}$ Parsifal tem por fonte lendas medievais que falam de duas relíquias cristãs: a lança com a qual Cristo foi ferido na cruz, e o Graal, cálice usado para recolher o Seu sangue, após a crucificação; por essa razão, a personagem Parsifal é associada a Jesus, sendo, em algumas representações teatrais, o próprio Cristo.
} 
às velhas lendas célticas e germânicas e às criações espontâneas dos velhos mitos.” (MATTOS, 1959, p. 48).

O compositor alemão despertava o interesse de Rosa, como podemos inferir a partir das suas anotações pessoais, que se encontram em Estudos para obra de Guimarães Rosa, no IEB-USP. Em São Marcos, como vimos, é mencionado Venusberg. Tenha ou não o Parsifal fornecido a Rosa algum elemento significativo na elaboração de A hora e vez de Augusto Matraga, a verdade é que o par de personagens Parsifal e Kundry tem algumas semelhanças inquietadoras com o par Matraga e BemBem, a começar pelas dificuldades de caracterização: como Matraga, Parsifal atinge o estatuto de redentor após passar por duros sofrimentos e lutar contra as tentações; pela compaixão, adquire a verdadeira sabedoria; no entanto, o fato de ser o eleito não o exime da árdua tarefa de vencer a si próprio. Por outro lado, a figura de Kundry é ainda mais complexa: ela é o bem e o mal ao mesmo tempo, é ela quem submete Parsifal às tentações, como Joãozinho Bem-Bem faz com Matraga. Parsifal, como Bem-Bem, pratica a continência sexual, desconhece a sua origem, tem muitos nomes e chega casualmente ao local em que o drama se desenvolve.

A questão que estamos abordando é relevante, se considerarmos a possibilidade da androginia da personagem, sugerida pela presença simultânea de características masculinas de estatura, olhar dominador, valentia e coragem, com características femininas. A androginia é um aspecto particular da união dos opostos. Tratando da questão, Mircea Eliade ressalta que a coincidentia oppositorum se apresenta em muitos ritos e mitos, que a ambivalência da divindade constitui tema encontrado em toda a história religiosa da humanidade e que a busca do Ser-Uno oculto sob a multiplicidade e a heterogeneidade pode ser observada nos Upanishades. A androginia de Joãozinho Bem-Bem, como manifestação da união de opostos, não seria um caso único na obra de Rosa, e Diadorim é a personagem que de imediato acode à mente. Joãozinho Bem-Bem, como Diadorim, recusa o sexo e a paternidade, é valente, leal, benevolente e justiceiro, porém ao mesmo tempo maligno e vingativo.

As tentações a que Joãozinho Bem-Bem submete Matraga não são os únicos elementos que possibilitam estabelecer a identificação do cangaceiro com o diabo. “Satanaz” é o nome que o velho, pai do assassino de Juruminho, dá a Bem-Bem, numa frase que mais se assemelha a uma cerimônia de exorcismo: “- Pois então, satanaz, eu chamo a força de Deus p'ra ajudar a minha fraqueza no ferro da tua força maldita!...” (p. 366). Outra pista de interesse é dada no emprego da palavra “rabo”. Nas representações 
figurativas da Idade Média na Europa, o diabo, normalmente, tem rabo. O mesmo ocorre nas manifestações populares brasileiras (lendas, literatura de cordel etc.); também com rabo ele é descrito no Fausto, de Goethe: “A cultura, outrossim, que lambe o mundo à roda, / Tem-se estendido sobre o diabo; / O nórdico avejão já não está na moda; / Onde vês garras, chifres, rabo?” (GOETHE, 1997, p. 118) (notar que o fantasma vem do norte, de onde também vem Bem-Bem). O termo “rabo” aparece no conto em três situações, sempre com referência a Joãozinho Bem-Bem. A primeira, em Tombador: "E seu Joãozinho Bem-Bem, que, com o rabo-do-olho, não deixava de vigiar tudo em volta, virou-se, rápido, para o Epifânio, que mexia com a winchester” (p. 350). A segunda, no momento em que Matraga, retornando a Murici, próximo de onde partira, reencontra o cangaceiro e este lhe diz: “Nós estamos de saída, mas ainda falta ajustar um devido, para não se deixar rabo para trás...” (p. 369). Mais adiante, após a morte de Joãozinho Bem-Bem, “rabo” aparece pela terceira vez: “Alguém gritou: “Eh, seu Joãozinho Bem-Bem já bateu com o rabo na cerca!” (p. 363).

Roberto Schwarz, analisando o tratamento dado ao mito em Grande sertão e Dr. Faustus de Thomas Mann, conclui que o demônio não tem existência material nas duas obras, é o produto do contato dos homens com o mundo e da interpretação humana. (SCHWARZ, 1981, p. 46). Riobaldo é fértil fonte de informações sobre o demônio na obra de Rosa; por exemplo, em "Explico ao senhor: o diabo vige dentro do homem, os crespos do homem - ou é o homem arruinado, ou o homem dos avessos. Solto, por aí, cidadão, é que não tem diabo nenhum. Nenhum!” (ROSA, J. G., 1956, p. 12). Uma anotação de Guimarães Rosa - com base na primeira edição de Grande setão: veredas , no caderno 12 dos Estudos para obra de Guimarães Rosa (IEB-USP), dá uma idéia da complexidade que o tema tinha para ele: “475 = (para mim, a página mais importante do Grande Sertão: Veredas)”. Rosa está se referindo ao momento em que Riobaldo fala sobre o fato de ter ou não feito o pacto com o demo: “... Então, não sei se vendi? Digo ao senhor: meu medo é esse. Todos não vendem? Digo ao senhor: o Diabo não existe, não há, e a ele eu vendi a alma... Meu medo é esse. A quem vendi? Medo meu é este, meu senhor: então, a alma a gente vende, só, é sem nenhum comprador...”. Uma opinião de Rosa sobre o demo foi emitida em sua entrevista a Lorenz, que transcrevemos quando analisamos São Marcos (COUTINHO, 1991, p. 73). Em A hora e vez de Augusto Matraga existe uma frase valiosa de mãe Quitéria sobre o demônio; diante do abatimento demonstrado por Matraga, ela diz: "Vira o demônio de costas, meu filho..." (p. 346). Parece clara aí uma concepção de demônio segundo a qual o homem pode ter 
total domínio sobre ele, sendo capaz de afastá-lo com a mesma simplicidade com que se vira uma imagem de costas. Com essa mesma conotação o demo é apresentado na passagem que antecede a decisão de Nhô Augusto de abandonar Tombador para ir ao encontro de "sua hora": "Levou o diabo, que eu nunca pensei que tinha tantos!" (p. 357), em que “tantos” concorda com o masculino “diabo” e não com os femininos maitacas e maracanãs,

Se, como afirma Roberto Schwarz, o demônio em Grande Sertão e no Fausto não tem existência material, podemos descartar a hipótese de que a figura de Joãozinho Bem-Bem personaliza o mal como um demônio cristão, uma vez que, no cristianismo, demônios são "seres espirituais hostis a Deus e aos homens. Belzebu é seu príncipe" (DOUGLAS, 1995, p. 398). Ele traz dentro de si a união dos opostos, da qual sua androginia e sua ambígua relação com o bem e o mal são indícios significativos; mesmo o duplo “Bem” de seu nome é mais uma das suas ambigüidades, porque no universo bipolar em que vive o ser humano, essa duplicidade traduz uma impossibilidade, a extirpação total do mal. ${ }^{41}$ Sua identificação como ente espiritual faz dele uma versão espelhada do Mefistófeles de Goethe, a personagem que tenta permanentemente praticar o mal e, involuntariamente, acaba operando o bem. "Sou parte da Energia / Que sempre o Mal pretende e que o Bem sempre cria” (GOETHE, 1997, p. 71). Joãozinho BemBem age segundo o princípio inverso: pensa estar fazendo o bem e a justiça, enquanto opera o mal. Ambos são personagens bipolares, como Lúcifer, que carregava a luz, até rebelar-se contra a harmonia do bem incontestável e desejar “cair” para o plano físico e bipolarizar-se em bem e mal ou macho e fêmea. Se completarmos o parágrafo anteriormente mencionado de Grande Sertão: Veredas, observaremos que nele existem os elementos que validam a idéia de que Bem-Bem quer ajustar tudo, entendendo estar fazendo o bem:

Viver é muito perigoso... Querer o bem com demais força, de incerto jeito, pode já estar sendo se querendo o mal, por principiar. Esses homens! Todos puxavam o mundo para si, para o concertar consertado. Mas cada um só vê e entende as coisas dum seu modo. Montante, o mais supro, mais sério - foi Medeiro Vaz. Que um homem antigo... Seu Joãozinho Bem-Bem, o mais bravo de todos, ninguém nunca pôde decifrar como ele por dentro consistia. (ROSA, J. G., 1956, p. 18).

\footnotetext{
${ }^{41}$ Guimarães Rosa mostra a importância da simetria do nome do cangaceiro em carta que enviou aos 04/03/65 à sua tradutora Harriet de Onís: “Como traduzir “Seu Joãozinho Bem-Bem”? Sugiro: 1) ou deixar: Mr. Joãozinho Bem-Bem; 2) Mr. Joãozinho Love-Love; 3) Mr. Joãozinho Dear-Dear; 4) Mr. Johnny Bem-Bem etc.”
} 
A frase já mencionada - "Vindos do norte, da fronteira velha-de-guerra, bem montados, bem enroupados, bem apessoados, chegaram uns oito homens” (p. 348) -, ao tornar indefinido o número de homens do grupo, passa a pôr em dúvida não só a identidade sexual da personagem, mas sua própria existência como ente físico.

Na primeira etapa de sua vida, Matraga possui uma forma de comportamento que é totalmente negada na segunda etapa. Na terceira etapa ela concilia as duas anteriores, e o descalabro vaidoso da primeira e o ascetismo culpado da segunda se fundem, resultando num ente harmonioso, como aquelas divindades simultaneamente benéficas e maléficas. Opera-se em Matraga a conciliação dos opostos apontada por Galvão, como vimos acima. O encontro de Matraga com Joãozinho Bem-Bem no final do conto é, dessa forma, a realização do encontro de um homem com sua faceta renegada num momento em que já não a renega mais. Logo, Joãozinho Bem-Bem é interpretado aqui como uma figura simbólica. Matraga morre simbolicamente ao saltar do barranco, após ser surrado pelos homens de Consilva. Sua segunda morte, nas mãos de Joãozinho Bem-Bem, adquire também significado simbólico, indicando que um novo ser vai nascer, mais perfeito do que o anterior. Lançando mão da nomenclatura do budismo, poderíamos dizer que, pela doutrina da transmigração, Matraga é um ser que sintetiza em duas vidas o aperfeiçoamento gradual que, por meio de reencarnações sucessivas, leva à abençoada paz do Nirvana. E o combate de Matraga com Joãozinho Bem-Bem adquire o mesmo significado dos combates míticos que, segundo Diel, fazem alusão aos conflitos humanos: “Assim, os combates heróicos dos mitos concretizam as aventuras essenciais de cada vida humana (...) Essas aventuras míticas em seu conjunto nada são além da própria vida psíquica, suas manifestações e seus fenômenos.” (DIEL, 1991, p. 29).

Se Joãozinho Bem-Bem não é figura do mal - Matraga o vê como um deus: “montado num sonho bonito, no qual havia um Deus valentão, o mais solerte de todos os valentões, assim parecido com seu Joãozinho Bem-Bem.”(p. 358) -, alguns aspectos do conto suscitam dúvidas quanto a Matraga poder ser tomado como modelo do bem. Em primeiro lugar, está a fortíssima simpatia que nasce de imediato entre as duas personagens; o amistoso tratamento que mutuamente os dois homens se dispensam desde o primeiro até o último encontro mostra uma afinidade que põe em xeque a premissa de que eles são representantes de duas idéias conflitantes; parece razoável admitir que o experiente Joãozinho Bem-Bem consiga, num relance, enxergar por trás 
da humildade e da inocência de Matraga o destemido valentão sem escrúpulos que ele fora no passado e que dentro dele ainda se esconde, atributos que o tornariam utilíssimo ao bando do cangaceiro; segundo, ao poupar da morte uma ave - "Deixa a criaçãozinha de Deus.”, diz ele (p. 353) - e matar festivamente seres humanos do bando de Joãozinho Bem-Bem, com a justificativa de implantar a justiça, Matraga iguala-se moralmente ao cangaceiro, como pode ser visto na passagem em que o protagonista se benze, é comparado ao demônio preso e a demônios soltos e se rejubila com a violência:

- Êpa! Nomopadrofilhospritossantamêin! Avança, cambada de filhos-da-mãe, que chegou minha vez! ...

$\mathrm{E}$ a casa matraqueou que nem panela de assar pipocas, escurecida à fumaça dos tiros, com os cabras saltando e miando de maracajás, e Nhô Augusto grítando qual um demônio preso e pulando como dez demônios soltos.

- Ô gostosura de fim-de-mundo! ... (p. 367).

Em Sezão, a associação de Matraga com o demo é mais explícita no final do conto, graças à adição de uma frase de Bem-Bem, elogiando a coragem de Matraga e justificando a fuga de seus comandados: "Você desculpe, mano velho, essas perebas que me envergonharam... que sujaram nossa briga!... Também, tu parecia o capeta mesmo, no meio do fuzuê feio, mano velho! Por isso foi que eles correram... De homem só, eles não corriam, não!” (ROSA, J. G., 1937, p. 441). Quando analisamos o primeiro parágrafo do conto, afirmamos que “o homem” dava à personagem de Nhô Augusto a conotação de poder social e o aproximava de Cristo. No entanto, em Grande Sertão: Veredas, Homem é um dos muitos nomes pelos quais Riobaldo se refere ao demo (ROSA, J. G., 1956, p 41).

Como "o ruim com o ruim, terminam por as espinheiras se quebrar.” (ROSA, J. G., 1956, p 19), Matraga e Joãozinho Bem-Bem terminam por se destruir mutuamente, pois ambos, cada um a seu modo, tentam estabelecer a justiça.

Vamos, mais uma vez, recorrer a Grande sertão: veredas:

quem-sabe, a gente criatura ainda é tão ruim, tão, que Deus só pode às vezes manobrar com os homens é mandando por intermédio do diá? Ou que Deus - quando o projeto que ele começa é para muito adiante, a ruindade nativa do homem só é capaz de ver o aproximo de Deus é em figura do Outro? Que é que de verdade a gente pressente? Dúvido dez anos. (ROSA, J. G., 1956, p 41).

O parágrafo acima pode reforçar a idéia de que Joãozinho Bem-Bem seja o Outro, o diá mandado por Deus para Nhô Augusto ver o “aproximo de Deus”; mas, se as duas personagens têm tantos pontos comuns, nada impede que interpretemos Matraga 
como o enviado a Bem-Bem, e, nesse caso, o encontro entre os dois homens representaria a salvação de ambos e explicaria a alegria que encontram na morte.

Existe uma frase intrigante na passagem acima de Grande Sertão: Veredas, jogada no texto, sem mais nem menos: “Dúvido dez anos.” Pensamos que Riobaldo esteja se referindo aos dez anos transcorridos entre a publicação de Sagarana e a de Grande Sertão: Veredas

Roncari, em O Brasil de Rosa, demonstrou a presença de mitos gregos em Sagarana e em Grande Sertão: Veredas. (RONCARI, 2004). Nesta nossa interpretação de Sagarana, também temos encontrado referências a mitos gregos ${ }^{42}$, especialmente da Ilíada. Transcrevemos abaixo aquelas que dizem respeito diretamente ao conto que estamos analisando:

Joãozinho Bem-Bem

“My Lord Diomedes”. disse o all-daring excelente Odysseus, "there is no need for you to sing my praises, or to criticize me either, since you are talking to men who know me. Let us be off”...(pg 187)

Rosa está aqui se reportando à fala de Bem-Bem: “- Prosa minha não carece de contar, companheiro, que todo o mundo já sabe.” (p. 350). Outra notação - “(Joãozinho Bem-Bem e Matraga. importante: pg. 387)” - deve estar se referindo às palavras de Aquiles nos versos 280 a 282 do canto XXI: “Antes, Héctor, o mais forte troiano, me matasse: um bravo derrotando outro bravo” (HOMERO, 2001, vol II, p. 339), que encontram paralelo nas de Joãozinho Bem-Bem após o combate com Matraga: “Morro, mas morro na faca do homem mais maneiro de junta e de mais coragem que eu já conheci! . . . Eu sempre lhe disse quem era bom mesmo, mano velho... É só assim que gente como eu tem licença de morrer... “(p. 369). Na notação que se segue, mais uma vez Guimarães Rosa faz menção a Joãozinho Bem-Bem - “Importante (J. Bem-Bem): pg. 388 (mano velho...)” - e alude à forma pela qual Escamandro chama Simoente para enfrentar Aquiles, no verso 309 do canto XXI: “Unamo-nos, irmão, contra a força desse homem” (HOMERO, 2001, vol II, p. 339).

Em três ocasiões, portanto, Joãozinho Bem-Bem é assimilado a três diferentes personagens da Ilíada; por outro lado, a persistência de referência à Ilíada indica que $A$ hora e vez de Augusto Matraga pode guardar alguma forma de relação com a mitologia

\footnotetext{
${ }^{42} \mathrm{O}$ interesse de Guimarães Rosa pela mitologia pode ser constatado por suas anotações nos cadernos que se encontram no Documento E17 dos Estudos para obra de Guimarães Rosa (IEB - USP). Sobre o assunto, ver também COSTA, 1997-98, ps. 47-62
} 
grega, pois é o único conto de Sagarana que, em suas anotações, o autor, estabelece ligação com Homero. Acresce que, dos sete acompanhantes de Joãozinho Bem-Bem, três possuem nomes gregos - Epifânio, Zeferino e Teófilo - e os outros quatro são chamados por apelido: Flosino Capeta, Tim Tatu-tá-te-vendo, Juruminho e Cangussu, não sendo possível, portanto, detectar a origem de seus nomes. Certamente tais apelidos devem significar alguma coisa que não nos foi possível descobrir, porém vale a pena mencionar a ambigüidade contida nos nomes de Flosino Capeta e Teófilo Sussuarana, ambigüidade que parece refletir o caráter paradoxal do chefe: Flosino Capeta, junção de flor e diabo é o homem que "que nunca se apartava do chefe” (p. 349), e Teófilo Sussuarana, desencadeante da luta do final do conto, é, ao mesmo tempo, amante de Deus e onça.

O período “Dona Dionóra, que tinha belos cabelos e olhos sérios, escutou aquela resposta, e não deu ar de seus pensamentos ao pobre camarada Quim. Mas muitos que eles eram, a rodar por lados contrários e a atormentar-lhe a cabeça, e ela estava cansada, pelo que, dali a pouco, teve vontade de chorar.” (p. 328) é ambíguo, pois a frase "Mas muitos que eles eram, a rodar por lados contrários e a atormentar-lhe a cabeça” pode estar se referindo tanto aos cabelos de Dionóra quanto aos seus pensamentos. A relação afetiva da personagem com Ovídio, homônimo do poeta latino, a referência aos cabelos, ao olhar e ao choro da personagem, sugerem recorrer ao episódio de Metamorfoses em que Perseu conta a história de Medusa, a horrível Górgona, cujos cabelos eram serpentes e cujo olhar petrificava qualquer criatura que a fitasse (OVÍDIO, 2003, p. 8993). Diel, na sua análise do mito de Perseu, estabeleceu a relação entre Medusa e as Erínias, e, como as Erínias são instrumentos de vingança divina e símbolo do tormento da culpa recalcada, o combate a Medusa deve ser idêntico àquele que protege contra as Erínias. (DIEL, 1991, p. 97). Na Divina Comédia, há uma menção às Erínias e outra a Medusa, seguidas do verso “Co’s unhas cada qual rasgava o seio” (ALIGHIERI, Inf, IX, 49), que traz à mente o tio nervoso de Dionóra: "Pernoitaram no Pau Alto, no sitio de um tio nervoso, que riscava a mesa com as unhas e não se cansava de resmungar” (p. 330).

A culpa, simbolizada nas Erínias e em Medusa, conforme Diel, transparece nos pensamentos de Dionóra: "E ela, Dionóra, tivera culpa, por haver contrariado e desafiado a família toda, para se casar” (p. 329). A culpa também é mencionada no encontro de Dionóra com o tio nervoso:

- Fosse eu, fosse eu... Uma filha custa sangue, filha é o que tem de mais valia.. . 
- Sorte minha, meu tio...

- Sorte nunca é de um só, é de dois, é de todos... Sorte nasce cada manhã, e já está velha ao meio-dia...

- Culpa eu tive, meu tio.. .

- Quem não tem, quem não teve? Culpa muita, minha filha...(p. 321)

Em Sezão não é mencionada nenhuma característica física de Dionóra, mas também não há referência ao sentimento de culpa.

É impossível afirmar que algo parecido com a relação entre Dionóra, as Erínias, Medusa, a culpa, Dante e Ovídio tenha sido considerado pelo autor. Porém, como a indicação de traços físicos de personagens é rara em Sagarana e sempre contém informações significativas, parece plausível estabelecer tais relações para justificar o nome de Ovídio e explicar a associação entre cabelos e serpentes, bem como a menção a olhos, choro e culpa, a que tão claramente se referem tio e sobrinha. A narrativa mostra que não se trata da culpa pelo adultério - que somente gera medo e nenhum outro sentimento especial na personagem -, mas culpa por um ato passado, pelo fato de ela ter sucumbido à vaidade de ser heroicamente arrancada de casa por um homem poderoso e importante como Nhô Augusto. A possibilidade de simplesmente interpretar Ovídio como uma personagem que, para conquistar a irresoluta Dionóra, lançou mão dos atributos de sedução cantados por seu homônimo, o poeta apaixonado, também parece viável, porém pouco ampla. É verdade que o poeta se refere aos cabelos de Corinna em Amores I, V, 10: “Con la chioma divisa a coprire il candore del collo.” (OVIDIO, 1994, p. 15), mas a interpretação que demos à personagem de Dionóra parece-nos mais abrangente.

Se Diónora pode ser associada à fatal Medusa, é plausível admitir que outras personagens do conto possam também ser identificadas com algum ente mitológico. É possível relacionar o diligente Quim Recadeiro com Hermes, zeloso e incansável mensageiro dos deuses olímpicos, particularmente de Zeus, que se ocupava da paz, da guerra e das questões amorosas entre os deuses. O nome Quim pode ser uma referência mnemônica a Quíone, mulher com a qual Hermes teve o filho Autolico. Em várias passagens do conto (p. 328) podemos observar o zelo com que Quim cumpre seu papel de mensageiro; leva a notícia da fuga de sua mulher com Ovídio - “Jogou fora, e cuspiu em cima. E tocou para trás, em galope doido, dando poeira ao vento. Ia dizer a Nhô Augusto que a casa estava caindo.” (p. 332) - , em uma passagem que remete à Odisséia: “O mensageiro brilhante, de pronto, ao mandato obedece. Calça, sem perda de 
tempo, as bonitas sandálias de ouro e divinas, que por sobre as águas, sem mais, o conduzem, como também pela terra infinita, qual sopro do vento.” (HOMERO, s/d, p. 80; V, 43 a 46). Quim Recadeiro tem a incumbência dolorosa de notificar a Nhô Augusto que sua mulher o abandonara por Ovídio, assim como Hermes, a contragosto, informa Calipso da solicitação de Zeus para que deixe partir Odisseu: "Vim aqui contra a minha vontade, pois por Zeus sou mandado.” (HOMERO, s/d, p. 81; V, 99). Todas as tarefas de Quim no conto são desagradáveis: traz a Nhô Augusto o recado de que a mulher queria falar-lhe, volta com o recado de Matraga para Dionóra de que não irá ao Morro Azul, narra a fuga de Dionóra, traz a notícia a Nhô Augusto de que seus homens o abandonaram. Ao servir de intermediário entre outras personagens e Nhô Augusto, homem prestes a morrer simbolicamente, Quim se assemelha a Hermes, que atravessa a fronteira sinistra que separa os vivos dos mortos (BURKERT, 1993, p. 310).

Convém esclarecer que o fato de serem estabelecidas relações da mitologia grega com personagens e trechos do conto não significa que estejamos diante de uma transposição pura e simples da mitologia para o a obra; vimos que Bem-Bem é associado a Ulisses, Aquiles e Escamandro pelo autor, mas a nenhuma dessas personagens isoladamente; portanto, no texto rosiano, não é possível reconstituir coerentemente o panteão grego e o intrincado tecido de parentescos entre as personagens olímpicas a partir do indício de que Dionóra é identificada a Medusa, e Quim Recadeiro, a Hermes.

A vida de Matraga, que “dera conta do homem da foice” (p. 329), tem pontos comuns com a de Zeus, arquétipo do chefe de família patriarcal, que isolou Cronos, o homem da foice, numa prisão subterrânea. Para escapar ao pai, que engolia os filhos recém-nascidos, na tentativa de impedir a realização do vaticínio de que seria destronado por um deles, Zeus foi isolado do mundo por sua mãe Géia num antro profundo nos flancos do monte Egéon, cercado pelos Curetas e amamentado pela cabra Amaltéia. Atingida a idade adulta, derrotou os inimigos, dentre os quais o pavoroso gigante Tifão, e assumiu o governo do mundo. Matraga, por sua vez, é marcado a ferro, precipita-se no barranco e ali recomeça da origem, como se renascesse para uma nova vida após uma morte simbólica. Zeus também havia sido marcado, porém com um aleijão provocado por Tifão que, com uma foice (segundo "homem da foice” de quem Zeus dá conta), cortou-lhe os tendões dos braços e dos pés e o conduziu à gruta.

Segundo Cornford, o significado do mito do herói engolido e vomitado por um monstro e do da criança arrancada à mãe que sobrevive alimentada por animais deve ser 
relacionado com as noções de morte e renascimento e com o espírito de fertilidade (CORNFORD, 1952, p. 352). Discorrendo sobre os costumes dos camponeses europeus, Burkert afirma que "tanto os costumes Antigos como os actuais manifestavam-se como uma expressão de representações religiosas “originárias” que se agrupavam em redor do crescimento e da fertilidade das plantas, dos animais e dos homens durante o ano; o “espírito da vegetação”, que constantemente morre para voltar depois a nascer, tornouse a idéia directriz.” (BURKERT, 1993, p. 23-24). O mito de Zeus, ainda segundo Cornford, reapareceria mais tarde nos mistérios de seu filho Dioniso. Cornford refere-se a Martin Nilsson, para quem o culto de Dioniso se liga à crença no deus renascido e moribundo, que é, na origem, o espírito da vegetação. (CORNFORD, 1952, p. 353).

A partir dessas observações de Cornford, Burkert e Nilsson, podemos fazer uma associação interessante da personagem de Matraga com o filho de Zeus, Dioniso, “aquele que vem” (BURKERT, 1993, p. 319). A mãe de Nhô Augusto morreu quando este ainda era criança, assim como Sêmele, mãe de Dioniso, foi reduzida a cinzas em decorrência de uma trama de Hera. Dioniso passou parte da vida longe do Olimpo e dos atos malévolos de Hera, e foi criado pelas ninfas e mênades num local distante e misterioso, da mesma forma que Nhô Augusto foi criado pela avó quando criança e, adulto, foi assistido por Quitéria e Serapião, longe dos perigos representados pelo Major Consilva e seus capangas. Dioniso teve de realizar longo e perigoso percurso e vencer obstáculos difíceis para finalmente ser reconhecido como deus, retornar ao Olimpo e estabelecer seu culto; Matraga também percorre sete anos de árdua caminhada, durante os quais pratica um ascetismo permanentemente perigoso para a sua alma, retorna ao local de onde partira e, finalmente, é reconhecido como enviado de Deus pela população de Rala-Coco.

O nome "Dionóra” tem semelhança fonética com nome do filho de Zeus e de Sêmele, o que leva a crer numa referência indireta à personagem Matraga: por meio de sua mulher - como já havia sido feito no caso do nome Quim Recadeiro, que remete ao nome da mulher de Hermes, Quíone - ou da correspondência de Dionóra com Medusa, a que remete o nome Ovídio. Como já se disse, o nome "Matraga” pode estar relacionado a trágos (bode), lembrando o bode expiatório e, com a tragédia, o canto do bode. Visto que o "ditirambo, tal como a tragédia, pertence ao quadro das festas em honra a Dioniso.” (BURKERT, 1993, p. 321), pode existir uma relação entre Matraga, 
tragós, tragédia e Dionisos. Para comprovar essa relação, precisamos analisar se A hora e vez de Augusto Matraga possui algumas das características gerais da tragédia. ${ }^{43}$

Não cabe aqui discutir em pormenores se A hora e vez de Augusto Matraga pode ou não ser classificado como tragédia, pois a busca da resposta ensejaria uma longa explanação das idéias dos numerosos pensadores, modernos e contemporâneos, que trataram da definição do conceito - Schiller, Hegel, Schopenhauer, Nietzsche, Unamuno, Auerbach e muitos outros -, às vezes conflitantes entre si. Mas a presença de figuras mitológicas na obra, e o fato de o nome de Matraga levar implícito o termo tragédia, sugerem a possibilidade de buscar no conto elementos que permitam caracterizá-lo como uma obra em que pelo menos podem ser encontrados traços trágicos significativos.

Para Vernant, a característica marcante da tragédia é a ambigüidade decorrente do fato de que os sentimentos, as falas e os atos do herói trágico, por um lado, dependem de seu caráter, isto é, de seu ethos, e, por outro, são expressão de uma potência religiosa, de um daimon que age através deles:

A todo momento a vida do herói se desenrola como que sobre dois planos, cada um dos quais, tomado em si mesmo, seria suficiente para explicar as peripécias do drama, mas que a tragédia precisamente visa a apresentar como inseparáveis um do outro: cada ação aparece na linha e na lógica de um caráter, de um ethos, no próprio momento em que ela se revela como a manifestação de uma potência do além, de um daimon. (...) Desde que deixa de ser possível lê-la tanto num sentido quanto no outro (como a simetria sintática permite) a fórmula perde o seu caráter enigmático, sua ambigüidade e não há mais consciência trágica porque, para que haja tragédia, o texto deve significar ao mesmo tempo: no homem, o que se chama daimon é o seu caráter - e inversamente: o que se chama caráter é realmente um demônio. (...) a lógica da tragédia consiste em "jogar nos dois tabuleiros”, em deslizar de um sentido para o outro, tomando, é claro, consciência de sua oposição, mas sem jamais renuncia a nenhum deles. (VERNANT, 1999, p. 15)

A hora vez de Augusto Matraga desenvolve-se nesses dois campos simultaneamente. O texto é abundante em exemplos nos quais as personagens sentem, pensam e agem em resposta ao seu caráter, mas, ao mesmo tempo, parecem obedecer ao comando de uma potência que lhes é superior. É possível notá-lo ao longo de toda a narrativa: Dionóra, por exemplo, afirma que o sofrimento decorrente de sua ligação com

\footnotetext{
${ }^{43}$ A noção de que a tragédia grega tem origem religiosa é consagrada na literatura sobre o tema e supomos que Rosa se apoiasse nessa mesma noção. Mas Vernant se opõe à ligação entre religião e tragédia (VERNANT, 1999, p. 158-161).
} 
Nhô Augusto é obra de destino - "Sorte minha, meu tio..." - e, logo em seguida, afirma que é responsável por essa mesma ligação - “Culpa eu tive, meu tio...” (p. 330).

Se admitirmos que A hora vez de Augusto Matraga guarda características da tragédia; se no nome de Matraga está implícita a tragédia; e se Matraga pode ser a representação sertaneja de Dioniso, somos tentados a procurar a figura mitológica que possa estar associada a Joãozinho Bem-Bem e o sentido do seu combate com Matraga. Essas questões, para a quais não ousaríamos arriscar respostas incisivas, abrem vasto campo de pesquisas, mas é grande a tentação de pensar que a luta amistosa entre as duas personagens expressa a fusão da polaridade dos espíritos dionisíaco e apolíneo, conforme definidos por Nietzsche: "a evolução progressiva da arte resulta do duplo caráter do ‘espírito apolíneo’ e do ‘espírito dionisíaco’, tal como a dualidade dos sexos gera a vida no meio de lutas que são perpétuas e por aproximações que são periódicas.” (NIETZSCHE, s/d, p. 19). De fato, Joãozinho Bem-Bem tem algumas características similares às de Apolo: estatura física, número de seguidores - sete, que é o número de Apolo (BURKERT, 1993, p. 289) -, comportamento, que vai da candura à extrema violência - Apolo massacra sem compaixão todos os filhos de Níobe por esta haver ofendido Leto, sua mãe (BURKERT, 1993, p. 291) -, e o duplo papel de deus da cura e deus da peste, que remete a Bem-Bem, que ora ajusta tudo ao padrão ético tácito que vigora no sertão, ora provoca terror.

Também é possível constatar em A hora e vez de Augusto Matraga a presença de hierofanias do céu, do sol, da lua e das águas. Ao tratarmos deste assunto, é nosso objetivo mostrar que uma outra dimensão religiosa, ainda mais antiga, está presente na obra, além daquelas representadas pelo cristianismo e pela mitologia.

O céu é nomeado treze vezes no conto, a maior parte das quais com a conotação do local no qual Deus habita, para onde o herói ser levado, lutando por isso com todas as suas forças para. Um trecho já mencionado acima da carta remetida por Guimarães Rosa a Harriet de Onís em 04/03/65 enseja uma interrogação: “ele (sua alma / his soul) vai embora daqui (deste mundo); morre, muda-se para plano mais alto (o céu?)” (IEBUSP). Mircea Eliade afirma que existem deuses celestes em profusão em todas as partes do mundo. A montanha, por estar mais próxima do céu, participa do simbolismo da transcendência - alto, vertical, supremo, etc. -, além de ser morada dos deuses. Todas as religiões têm uma montanha sagrada que representa o centro do mundo (ELIADE, 2002, 
p. 39-101). Essas considerações de Eliade permitem interpretar também fora do âmbito exclusivamente cristão a frase “P’ra o céu eu vou, nem que seja a porrete!”.

Falamos da associação do sol a Jesus Cristo, formulada por Ruysbroeck. De modo geral, no entanto, o sol tem presença reduzida como símbolo divino no cristianismo, quando comparado a outras religiões. Por isso, a quase totalidade das menções ao sol feitas no conto - e também nos demais contos de Sagarana - leva-nos a identificar o astro como portador de um sentido místico, possível de ser entendido fora da esfera cristã, como o de um observador singular de um momento narrado.

As relações da lua com a chuva, com a vegetação e com a mulher também foram mostradas por Eliade (ELIADE 2002, p. 127-73). A lua é mencionada no conto em quatro momentos: a primeira, imediatamente antes de Dionóra entrar em cena: “E ia, no alto do mato, a lentidão da lua.” (p. 328). A segunda, quando o narrador descreve a incansável vontade de Nhô Augusto de trabalhar - supõe-se que na lavoura - e de ajudar ou outros: "Mas, ele, tinham-no visto mourejar até dentro da noite de Deus, quando havia luar claro. Não pensava nada... E as mariposas e os cupins-de-asas vinham voar ao redor da lamparina... Círculo rodeando a lua cheia, sem se encostar...” (p. 341); a terceira, quando se iniciam as chuvas: “A casca de lua, de bico para baixo, ‘despejando'...’(p. 347); e finalmente a quarta, na melopéia do cego conduzido pelo bode, a que já nos referimos. A primeira menção à lua está, portanto, associada com a mulher, e as demais, com Matraga, com a vegetação e com as chuvas. A conexão de Matraga com a lua e com a vegetação reforça sua condição dionisíaca. A água, cuja simbologia tem estreita relação com a da lua, apresenta-se na obra em forma da chuva, que será portadora da graça para o protagonista.

O termo "fogo", em diversas conotações, aparece no conto nada menos que nove vezes, todas relacionadas com a personagem. Os quatro últimos versos da cantiga do cego com o bode fazem referência a fogo e água, sol e lua. O fogo é um símbolo positivo ou negativo em várias religiões, mas é na doutrina hindu que ele adquire maior importância e a maior variedade de conotações.

Quando analisamos o episódio que narra a surra aplicada pelos capangas do major Consilva em Nhô Augusto, levantamos a aparente relação com a Via Crucis de Jesus e nos referimos ao fato de que a cena lembrava o ritual de malhação de Judas com porretes. No entanto, essa interpretação, feita sob a ótica cristã, não deixa de ser igualmente válida sob a ótica de qualquer outra religião. De fato, a cena tem características muito mais próximas de uma imolação, que é explicada por Girard como 
sendo "substituição sacrificial”, isto é, comportamento de proteção dos membros da sociedade contra sua própria violência (GIRARD, 1998, p. 13).

Dissemos anteriormente que o número três tem presença constante na obra, fato que foi por nós associado à Santíssima Trindade, símbolo central da fé cristã. Mas a presença de trios também não garante a exclusividade da interpretação cristã do conto: trindades são também Brahma, Shiva e Vishnu na Índia; Osíris, Ísis e Hórus no Egito; a Jóia Tripla do budismo (Buda, Darma, Sanga); Anu, Bel e Ea na Babilônia; Sin (Lua), Shamash (Sol) e Adad (Tempestade), também na Babilônia. De fato, se formos ao verbete três de qualquer dicionário de símbolos, ficaremos atônitos com a persistência das tríades em todas as religiões ou crenças. Jung abordou o assunto, salientando que no estágio primitivo do pensamento humano já aparecem tríades divinas, e que existe um sem-número de tríades arcaicas nas religiões antigas e exóticas (JUNG, 1983). Para Jung, as idéias arquetípicas, como a da tríade religiosa, pertencem aos fundamentos indestrutíveis do pensamento humano e, embora fiquem esquecidas e soterradas por longos e longos anos, sempre voltam, muitas vezes sob disfarces estranhos e deformações pessoais, ou deturpadas racionalmente. Portanto, a origem das tríades deve ser buscada no estágio mais primitivo do pensamento humano, e sua presença no cristianismo nada mais é que um elo dessa corrente.

A marcha de uma divindade sobre um animal, aparentemente tão ligada à vida de Cristo, não é exclusividade cristã. Na Índia, por exemplo, deuses se servem de animais para montaria - vaca, boi, tigre, leão - e Kalaratri é com freqüência representada sobre um asno.

Quando analisamos o conteúdo cristão na obra, insistimos na presença do destino e da graça como fio condutor da vida das personagens. Mas o destino, de uma forma ou de outra, está presente em quase todas as religiões. E, se por um lado, a onipotência dos deuses quase sempre faz que aos humanos restem reduzidas possibilidades de agir livremente, por outro lado, esses mesmos deuses estão sempre prontos a punir de maneira impiedosa os humanos pela prática daquelas mesmas ações que, em princípio, foram por eles motivadas. É dessa ambigüidade, inerente à tragédia, que fala Vernant no texto acima transcrito. Se tomarmos o caso do islamismo, distante no tempo em relação à mitologia grega, verificaremos a enorme complexidade do tema do destino:

no islamismo, a liberdade humana sofre a tensão da onipotência de deus, o que indicaria predestinação. A teologia islâmica se debate interminavelmente com essa tensão, sem 
resolvê-la racionalmente. Sua conclusão é que as obras do Decreto Divino permanecem um mistério para os seres humanos, os quais, mesmo assim, recebem suficiente liberdade e responsabilidade para tomarem decisões morais e espirituais genuínas. O que anteriormente se disse sobre o livre-arbítrio vale para a maioria das religiões e o assunto é tão polêmico no cristianismo quanto em qualquer outra crença. (SMITH, s/d, p. 233).

Com essas considerações, podemos afirmar que uma leitura exclusivamente cristã de A hora e vez de Augusto Matraga pode ser pertinente, mas não suficiente. Os elementos que induzem à concentração na dimensão cristã da obra provêm, em grande parte, das manifestações orais de personagens imersas na cultura do cristianismo sertanejo: o padre, o casal de negros, o velho pai do assassino do Juruminho, o próprio Matraga e outros; não existem, contudo, elementos textuais que nos assegurem que as referências cristãs emitidas pelas personagens representem e esgotem o conteúdo religioso do texto; a maior parte das referências cristãs apontadas até aqui pode ter interpretação fora do âmbito do cristianismo também, como vimos; por outro lado, também vimos que não há antagonismo, mas, ao contrário, complementação e enriquecimento, entre a leitura cristã e a, digamos, leitura mitológica, que na verdade, engloba e extrapola a primeira.

O conto admite também uma leitura à luz do neoplatonismo, que considera a queda e a ascensão de Nhô Augusto nos termos das idéias de Plotino sobre as alternativas de queda e ascensão do homem. Se examinarmos alguns trechos da segunda e da terceira etapa da vida de Matraga, referentes à relação da personagem com a natureza (na primeira etapa esta não é mencionada), notaremos que ela vai assumindo, de modo crescente e gradual, papel de relevo na vida do protagonista, ao mesmo tempo em que vai se tornando mais e mais amigável. Na descrição da fuga de Nhô Augusto e do casal de negros rumo a Tombador, a natureza entra como pano de fundo da caminhada e ora se mostra inimiga, ora amistosa com o trio (p. 341). Passados "pelo menos seis ou seis anos e meio” (p. 343), vemos Nhô Augusto rezando e fugindo das tentações; ele vê em seus atos ascéticos a mesma força impulsionadora da harmonia da natureza em suas surpreendentes manifestações - não em suas belezas monumentais, mas em pequenas coisas, como na casa do cupim ou na ação do tico-tico, que leva comida ao filhote do pássaro preto (p. 343). O trecho seguinte mostra o herói totalmente integrado na natureza, apreciando-a e antevendo na chuva o período auspicioso que se aproxima. É o período que se inicia com “Até que, pouco a pouco, devagarinho, 
imperceptível” e termina com “Choveu” (p. 347). A passagem seguinte distingue-se da anterior pelo fato de mostrar o herói em plena contemplação da natureza. O mundo que se lhe apresenta é novo, pois ele pode agora ver a beleza em toda a sua plenitude, fato que é mostrado numa longa exposição já parcialmente transcrita, que se inicia com "De repente, na altura, a manhã gargalhou” e se encerra com “Ô papagaiada vagabunda! já devem de estar longe daqui...” (p. 357-58). Nessa texto, as maitacas atuam como transmissores da ordem divina para que Nhô Augusto inicie sua caminhada, guiado pelo burrinho. Esse fato é mais explícito em Sezão, porque há uma inserção: "E sentou no chão, para apreciar. Imprudentemente. Porque nem mesmo as maitacas não sabem que ordens, para quem está cá embaixo, elas tiveram ordem de transmitir.” (ROSA, J. G., 1937, p. 431). A função dos pássaros, de mediadores entre o homem e o divino, foi apontada em nossa análise de São Marcos.

A contemplação como forma de se chegar ao Uno - o Princípio Supremo, a fonte original - foi tratada por Plotino em sua Enéadas, da qual Guimarães Rosa extraiu alguns trechos que utilizou em quatro epígrafes dos três volumes de Corpo de baile. As idéias de Plotino sobre a beleza estão intimamente associadas à filosofia da contemplação, e a alma que é capaz de reconhecê-la é conduzida para o alto, purificada, passa a pertencer ao divino, que é origem da beleza. ${ }^{44}$

Como conseqüência do encontro com Quitéria, Serapião e o padre, Matraga fixa um objetivo de salvação que passará a seguir firmemente. Principia então a sua longa via ascendente, durante a qual vai progressivamente passando a desempenhar os papéis das três espécies de seres humanos às quais se referiu Plotino: inicialmente, junta forças e luta tenazmente para vencer todos os vestígios do passado e os impulsos de seu caráter violento e perverso; depois, eleva-se acima das coisas inferiores, seus atos são honestos e bondosos, mas ele ainda se preocupa permanentemente com a escolha que deve fazer

\footnotetext{
${ }^{44}$ No documento I6 do IEB-USP, Estudos para obra de Guimarães Rosa, encontramos algumas anotações pessoais do autor sobre Plotino que guardam estreita relação com a trajetória de Matraga no conto: O tema constante da (predicação) pregação plotiniana: "a fuga do mundo".

O ascetismo extremado de Plotino: déposse l'indifférence estóica, pois Ele chega no ponto de desejar a dor.

O tema principal, em torno do qual se centram todos os outros, é o tema da fuga da alma para fora do mundo sensível.

Que é esta beleza presente nos corpos? Esta é a primeira coisa a pesquisar.

Que é, pois, o que toma e atrai os olhares dos espectadores, e lhes faz experimentar a alegria na contemplação? Se descobrirmos essa beleza de corpos, talvez poderíamos nos servir dela como um degrau para contemplar as outras belezas.

O belo se encontra sobretudo na vista; etc. Há também, subindo das sensações para um domínio superior, ocupações, ações e maneiras de ser que são belas.

A obra de Plotino são verdadeiras apostilas.
} 
entre o bem e o mal, entre as coisas inferiores acima das quais tem o desejo de elevarse; finalmente, vê nas manifestações mais amplas da natureza a deslumbrante luz divina e aí permanece. Paralelamente à progressiva transformação interior, sua visão da totalidade da natureza - mulheres, paisagem, pássaros - vai também se modificando, como pôde ser visto tanto nos episódios que acima selecionamos, como no trecho abaixo.

Bastava-lhe rezar e agüentar firme, com o diabo ali perto, subjugado e apanhando de rijo, que era um prazer. E somente por hábito, quase, era que ia repetindo:

- Cada um tem a sua hora, e há-de chegar a minha vez!

Tanto assim, que nem escolhia, para dizer isso, as horas certas, as três horas fortes do dia, em que os anjos escutam e dizem amém... (p. 356-57)

Em Sezão, na quarta frase vinha adicionado um trecho sugestivo: "Nem pensou mais em morte, nem em ir para o céu, porque era como se no céu já estivesse.” (ROSA, J. G., 1937, p. 430). O herói alcança, portanto, a plena felicidade pelo abandono de si mesmo à Providência, expressivamente figurado em sua caminhada conduzida ao acaso pelo jegue.

A entrega total, como a que Matraga realiza na segunda e na terceira etapa de sua vida, é, segundo Smith, o ponto central em todas as religiões. Referindo-se ao islamismo, Smith menciona William James:

naqueles estados mentais que ficam aquém da religião, quem se entrega submete-se a uma imposição necessária, e o sacrifício, no melhor dos casos, é vivenciado sem queixas. $\mathrm{Na}$ vida religiosa, ao contrário, a entrega e o sacrifício são positivamente desposados: mesmo renúncias desnecessárias se acrescentam, para que a felicidade possa aumentar. A religião, desse modo, torna fácil e feliz aquilo que, de todo modo, é necessário. (SMITH, s/d, p. 232)

Com estas considerações, é possível concluir que A hora e vez de Augusto Matraga é uma obra de diversificado conteúdo religioso, devido a três fatores principais: primeiro, as manifestações sagradas: evidências, misturadas umas às outras, de cristianismo, mitologia, hierofanias e neoplatonismo; segundo, a ambigüidade das personagens Matraga e Joãozinho Bem-Bem, manifestada, no primeiro, por meio de atitudes simultâneas de santo piedoso e demônio violento e, no segundo, por ações que pretendem a justiça e acabam em violência demoníaca; e, terceiro, a possibilidade de considerar Matraga e Joãozinho Bem-Bem, em conjunto ou separadamente, como personagens ficcionais comuns ou como figuras simbólicas. 
Se é possível associar Matraga e Joãozinho Bem-Bem a personalidades míticas de várias origens, o embate final e a morte simultânea dos dois homens do sertão permitem levantar a hipótese de que estamos presenciando uma luta mitológica, nos moldes do apocalipse nórdico, na qual os deuses se eliminam uns aos outros, para propiciar o renascimento de uma nova ordem no mundo. Na mitologia nórdica ${ }^{45}$ predomina extrema violência; seu apocalipse é o pavoroso dia do Ragnarök que, segundo descrição da Edda, será anunciado por vários eventos catastróficos; então Alfadur, o Todo-Poderoso, fará ressurgir do mar um novo céu e uma nova terra que terá recursos infindos e dará frutos sem necessidade de trabalho. A maldade e a miséria não serão conhecidas, e homens e deuses viverão eternamente felizes. Mostremos agora alguns aspectos que dão consistência a essa interpretação.

- A primeira evidência pode ser encontrada na carta de 04/03/65 que Guimarães Rosa endereçou a Harriet de Onís referindo-se ao nome Matraga: “...quis um nome, estranho, para ser assumido pelo herói somente no final, quando redimido e transformado, “recebe um nome novo” (creio que isto é do “Apocalypse”).” (IEBUSP, grifos do autor).

- Em relação à frase “Joãozinho Bem-Bem se sentia preso a Nhô Augusto por uma simpatia poderosa, e ele nesse ponto era bem-assistido, sabendo prever a viragem dos climas e conhecendo por instinto as grandes coisas.” (p. 367), Rosa orientou Onís, em carta de 04/03/65, sobre o sentido de "bem assistido" como "well protected (pelos bons espíritos, sobrenaturais, anjos, Deus, etc...)” (IEB-USP). O parágrafo adquire sentido místico e “viragem dos climas” pode ser entendido ao pé da letra, como grandes mudanças de clima que ocorrem no apocalipse nórdico.

- A associação do desfecho de Sagarana ao apocalipse nórdico permite explicar também, de modo muito apropriado, o título do livro, Sagarana. Tem sido tradicionalmente aceito que esse título é composto do vocábulo "saga”, tradição histórica ou mitológica típica dos países escandinavos, e "rana”, vocábulo tupiguarani para designar “à maneira de”, “tosco”. Contudo, na carta do autor à tradutora americana aos 09/02/65, Rosa assinala que o nome Sagarana ainda era obscuro para o leitor: "Daí, veja, por exemplo, a Snra.: a eficácia do título SAGARANA, totalmente novo, para qualquer leitor, e ainda não explicado, virgem de visão e de entendimento. Não é? Por isto, é que eu quereria que esse título fosse

\footnotetext{
${ }^{45}$ Os conceitos contidos a seguir foram extraídos das seguintes fontes: STURLUSON, 1993; BULFINCH, 1957, p. 336-359; DURANT, s/d, p. 446 - 453.
} 
conservado, na tradução em inglês, e em todas as outras.” (IEB-USP). Se admitirmos que o embate dos dois homens pode ser identificado como o combate travado pelos deuses escandinavos no apocalipse, o título Sagarana teria o sentido literal de uma saga tosca, uma saga sertaneja, enfim, uma saga brasileira.

- É de se supor que os três nomes dos locais em que A hora e vez de Augusto Matraga se desenrola, Murici, Tombador e Rala-Coco, tenham alguma relação com os acontecimentos neles narrados. Pode-se levantar a hipótese de que Rala-Coco, onde a luta entre Matraga e Joãozinho Bem-Bem se desenrola, seja derivado de Ragnarök - o apocalipse nórdico.

- As anotações já aludidas de Rosa sobre Wagner, algumas das quais se referem especificamente ao Anel, não constituem prova concreta de algum tipo de relação entre a Tetralogia, baseada na mitologia nórdica, e a leitura que aqui estamos dando ao desfecho do conto. No entanto, ela serve de estímulo ao leitor para estudar a viabilidade de tal relação.

O que se pode observar das várias leituras acima é que, se combinarmos ad libitum parte das evidências existentes no texto e abandonarmos outras, acabaremos por encaixar o conto em qualquer religião que quisermos ou em quantas religiões nos vierem à mente. Isso mostra duas coisas: existem indubitavelmente elementos para uma análise no campo religioso; e esse campo religioso não se limita ao catolicismo ou mesmo ao cristianismo, mas abrange outras possibilidades, inclusive mitológicas. Além disso, o caráter intrincado dos motivos presentes no texto ensejam interpretações multifacetadas, impedindo em absoluto leituras apologéticas e unívocas. Diante de uma obra tão aberta, portanto, reavivam-se as controvérsias que cercaram todas as crenças religiosas em todos os tempos. Os quatro sentidos da Bíblia, as quatro interpretações do apocalipse do Novo Testamento, os conflitos internos do cristianismo, nos primeiros séculos, entre donatistas, monofisitas, nestorianos, arianos, atanasianos, monofisitas e muitos outros, são exemplos - para somente ficarmos no cristianismo - dos debates que cercam os fatos religiosos. Assim, fica-se diante do problema de como condensar tantas leituras viáveis e possíveis numa interpretação que tenha abrangência bastante para cobrir a totalidade ou, pelo menos, a maior parte desses fatores. Na tentativa de fazê-lo, voltaremos ao ponto em que falamos da identificação de Matraga com Zeus e Dioniso.

As vidas de Zeus e de Dioniso abordam um mito persistente em muitas religiões: o de divindade cruel que procura eliminar uma criança divina ou semidivina que, 
segundo profecia, lhe usurparia o trono; mas as tentativas de eliminação da criança fracassarão, e a profecia se realizará. São muitos os mitos que, de uma forma ou de outra, seguem este esquema: Moisés no Egito, Krishna, na Índia, Perseu, Dioniso e Adônis na Grécia, Tammuz, na Babilônia, Osíris no Egito, e muitos outros. Tais mitos são derivados do mito central da fertilidade, como se disse. Moisés, por exemplo, foi colocado por sua mãe na margem do Nilo dentro de uma cesta para escapar à morte decretada pelo faraó para todos os judeus recém-nascidos; foi encontrado e adotado pela filha do faraó (BÍBLIA SAGRADA, 1964, p. 183 do Dicionário Prático). Krishna nasceu de modo milagroso, sem paternidade: o rei Kansa recebera de uma voz do céu o aviso de que seria morto pelo oitavo filho de Devaki, esposa de Vasudeva, e por esta razão matava os filhos recém-nascidos do casal; graças a uma complicada trama urdida por Vishnu, Krishna acabou sendo gerado por Devaki, como porção da própria Vishnu; Kansa, sabedor do fato, ordenou que todas as crianças vigorosas fossem mortas, mas Krishna conseguiu escapar e acabou por cumprir a profecia, matando Kansa. Perseu, filho de Dânae e Zeus, tem origem parecida com a de Moisés: o rei Acrísio, pai de Dânae, fora informado pelo oráculo de que seu neto o mataria; por isso, jogou sua filha e o recém-nascido Perseu no mar, também numa arca de madeira.

A vida do Cristo, narrada nos evangelhos, encaixa-se no modelo mitológico aqui descrito; como da narrativa de A hora e vez de Augusto Matraga é possível extrair uma identificação de Matraga com Cristo, o leitor acaba por concluir que está diante de um fundo essencialmente cristão. No entanto, é igualmente válido ver Matraga como representante não só do sincretismo cristão, mas de todas as religiões, sendo a sua aproximação com outras figuras religiosas e mitológicas tão válida quanto sua aproximação com Jesus.

Como vimos, nos contos de Sagarana existem referências a várias fontes religiosas universais e populares. Se A hora e vez de Augusto Matraga é, como disse o autor, de certo modo síntese e chave de todas as outras histórias de Sagarana, é de se prever nesse conto a presença de várias categorias religiosas. Esse fato foi constatado ao longo desta análise.

Partindo de uma história humana que se desenrola em dado espaço geográfico brasileiro e passando pelo paralelismo entre as proezas de seu protagonista e a trajetória de várias figuras religiosas ou mitológicas, podemos concluir que estamos diante da saga de uma divindade do sincretismo brasileiro - a "saga de Matraga”, escrita em tom bíblico no seu livro religioso, A hora e vez de Augusto Matraga. Seu caminho em muito 
se assemelha ao de muitas divindades de várias religiões, em todos os tempos. Matraga é membro de uma mitologia sertaneja, é o nosso Dioniso, nosso Zeus, nosso Perseu, nosso Krishna, nosso Tamuz, nosso Osíris, nosso Moisés. Entendida dessa forma, a obra, superando o microcosmo sertanejo, extrapola para um macrocosmo universal em cujo cerne se encontra o homem, visto através de suas transmudações. Matraga é uma delas.

Se Matraga é um membro da mitologia sertaneja brasileira, se $A$ hora e vez de Augusto Matraga é síntese das outras novelas de Sagarana, cabe então perguntar qual a relação entre a “saga de Matraga” e a representação do Brasil que, de acordo com a proposição deste nosso trabalho, o livro contém.

Como nos outros contos de Sagarana, em A hora e vez de Augusto Matraga existem várias passagens em que é feita alguma referência à sociedade brasileira. Uma dessas passagens, já mencionada na introdução deste trabalho, é aquela em que Joãozinho Bem-Bem fala da revolução de 30, na qual menciona Franklin de Albuquerque (p. 363).

Em Sezão, o cego com quem Nhô Augusto cruza em sua viagem sobre o burrinho, associa a Rui Barbosa o bode que o conduz: “...Companheiro de lei, que nem gente, que nem pessoa de sua família ... E, porque sabia tudo, pusera-lhe o nome de Rei-Barbosa... Nhô Augusto nunca tinha ouvido falar em Rei-Barbosa, e o cego ficou brabo com tanta ignorância de não se conhecer o nome do novo Imperador...” (ROSA, J. G., 1937, p. 434). Em Sagarana foi omitida a referência direta a Rui Barbosa, mas, a idéia geral de um animal conduzindo um cego para o norte é similar nos dois livros. De fato, existem no conto constantes referências à Bahia, terra natal de Rui: os homens de Joãozinho Bem-Bem eram todos baianos em Sezão, com exceção do próprio comandante, sobre cuja origem o leitor fica em dúvida (em Sagarana, a dúvida se estende a todos os componentes do bando); o cego se encaminha para Caitité, na Bahia; tanto Horácio de Matos, mencionado em Sezão, como Franklin Albuquerque, de Sagarana, eram baianos. É possível que o cego, ao chamar Rui Barbosa de novo Imperador estivesse se referindo às suas atividades na vida política do Brasil e, particularmente, na política baiana. Walfrido Moraes, em Jagunços e heróis, faz a apologia de Horácio de Matos e escreve que o objetivo do chefe jagunço era o de “Conflagrar os sertões e marchar sobre a capital, à sombra da bandeira desfraldada pelo glorioso conselheiro Rui Barbosa” (MORAES, W., 1991, p. 81). Sob o ponto de vista 
religioso, a passagem do cego com o bode foi interpretada como uma metáfora da obscura vida pregressa de Nhô Augusto rumando catastroficamente para o norte. Esta mesma passagem pode agora ter sua interpretação enriquecida como uma visão do futuro obscuro e incerto que estaria reservado ao Brasil caso tivesse seguido os passos do “Novo Imperador”. O cego seria, portanto, o símbolo representativo do povo baiano ou brasileiro conduzido por um sinistro bode que incorporaria os mandantes da política brasileira, para os rumos do norte.

Já no início do conto, no leilão na igreja de Murici, Nhô Augusto dá demonstrações públicas de uma riqueza de que já não desfruta e mostra-se como benevolente doador da igreja. A cena, portanto, sintetiza e reforça uma série de elementos que vimos observando nos outros contos: a arbitrariedade dos detentores do poder, a prática da violência física - ele pune com agressão o capiau apaixonado pela Sariema -, o uso da religião para a promoção individual. Mostra também a conversão de seres humanos em mercadorias, que são avaliadas por sua menor ou maior atração de consumo - "Beleza não tinham: Angélica era preta e mais ou menos capenga, e só a outra servia” (p. 324) -, e uma massa inconsciente e submissa que teme e, ao mesmo tempo, louva o protagonista.

Como ocorre nos outros contos de Sagarana, em A hora e vez de Augusto Matraga são visíveis: a ausência de aparato jurídico legalmente instalado; a vigência de estrutura social retrógrada; a permanente violência nas relações humanas, quer na esfera pública, quer na esfera privada; as lutas para assegurar e expandir o avultado poder dos grandes proprietários fundiários, como Consilva, Afonsão e Nhô Augusto; a regra da aliança e da vingança que norteia as conflituosas relações de Nhô Augusto com o “Major mais outros grandes” (p. 333), com o conseqüente alargamento do poder de Consilva; a peculiar estrutura de relações de classes, evidenciada na lealdade e subserviência do mandado Quim Recadeiro - mas que terminará, como Dionóra, também tendo sua hora e vez - perante a arrogância e a brutalidade do mandante Nhô Augusto. Por meio desse tipo de relação entre sadismo do dominante e masoquismo do dominado, parecem reproduzir-se as idéias de Gilberto Freyre, expressas em Casa Gande \& Senzala:

A nossa tradição revolucionária, liberal, demagógica, é antes aparente e limitada a focos de fácil profilaxia política: no íntimo, o que o grosso do que se pode chamar "povo brasileiro" ainda goza é a pressão sobre ele de um governo másculo e corajosamente autoritário. Mesmo em sinceras expressões individuais (..) de mística revolucionária, de messianismo, de identificação do redentor com a massa a redimir pelo sacrifício de vida ou 
de liberdade pessoal, sente-se o laivo ou o resíduo masoquista: menos a vontade de reformar ou corrigir determinados vícios de organização política ou econômica que o puro gosto de sofrer, de ser vítima, ou de sacrificar-se.

Por outro lado, a tradição conservadora no Brasil sempre se tem sustentado do sadismo do mando, disfarçado em "princípio de Autoridade" ou "defesa da Ordem". Entre essas duas místicas - a da Ordem e a da Liberdade, a da Autoridade e a da Democracia - é que se vem equilibrando entre nós a vida política, precocemente saída do regime de senhores e escravos. (FREYRE, 1989, p. 51-52).

A família tem presença marcante em A Hora e vez de Augusto Matraga, e sua importância é mostrada logo no início do conto, por meio da descrição da gênese do protagonista. Como regra geral, a narração se concentra nos pormenores da vida de Nhô Augusto; a única exceção, justamente, que mostra a importância da família no texto, ocorre quando o foco recai em Dionóra, em seus pensamentos secretos, suas mágoas e seus temores. É possível ver em A hora e vez de Augusto Matraga a desagregação da família patriarcal de Nhô Augusto como figura da falta de coesão social na sociedade autoritária brasileira; seu comportamento é o padrão do patriarca, que para a procriação tem mulher oficial e, para as outras funções do sexo, amantes de estratos sociais mais baixos; goza da fama de destruir famílias e, nas palavras de Quim Recadeiro, “estão dizendo que o senhor nunca respeitou filha dos outros nem mulher casada” (p. 333); no entanto, é no aconchego familiar ofertado pelo casal de negros, mãe Quitéria e pai Serapião, que Matraga chamará em desespero por sua mãe morta e receberá os cuidados que lhe salvarão a vida. É para proteger uma família, a do velho pai do assassino de Juruminho, que Matraga lutará até a morte com Joãozinho Bem-Bem. E, em suas últimas palavras, manda a bênção à sua antiga família, à filha que se prostituíra e à mulher que o traíra. Na verdade, podemos afirmar que as três etapas da vida de Matraga nas quais dividimos o conto, podem ser também definidas, na dimensão familiar, por desagregação, reorganização e redenção.

Afonsão pode ser entendido como uma referência à figura do Imperador Dom Pedro II, e sua morte representa o fim do Império no Brasil. De fato, no início do conto temos indicações da posição de destaque social do pai de Nhô Augusto, que tinha nome longo e pomposo, reforçado pelo aumentativo: Coronel Afonsão Esteves das Pindaíbas e do Saco-da-Embira. Podemos encontrar na obra outros indícios da categoria social dessa personagem: o sobrenome “Esteves” é o patronímico de Estêvão, forma popular de Estéfano, que, por sua vez, deriva da forma erudita Stephanus, do grego Stephanos, que significa coroa, diadema. Afonso, nome de vários reis de Espanha e Portugal, é 
derivado do alemão Adalfuns, e significa “inclinação (aptidão) nobre” (OLIVER, 2005). Afonsão, portanto, carrega contidas em seu sobrenome características de diligência, onipotência e ostentação. Ele é definido como "leso" (atoleimado, apatetado) e “pancrácio” (pateta, simplório). Referindo-se ao que pensa Dionóra sobre o marido, o narrador assim se exprime: “fora assim desde menino, uma meninice à louca e à larga, de filho único de pai pancrácio” (p. 329). Dom Pedro II era, para alguns, imperador moderado no uso do poder, que permitiu a mais irrestrita liberdade de imprensa e o funcionamento normal e permanente do Poder Legislativo, voltado para o desenvolvimento, impulsionador das artes, pacificador da nação, tolerante com os inimigos - como, por exemplo, no episódio da Questão Religiosa; em suma, um nobre gentil e diligente. Para seus detratores, um pancrácio e leso - em grande parte pela costumeira transmutação em defeitos das mesmas virtudes apontadas pelos seus admiradores - que se manteve distante das grandes decisões através do Poder Moderador, assistindo impassível às refregas entre liberais e conservadores e fechando os olhos para as manobras republicanas de incentivo ao Exército para a tomada do poder, empreendidas por Rui, Bocaiúva, Aristides Lobo, Benjamin Constant e outros. Uma das propriedades de Afonsão e Nhô Augusto é o Morro Azul. Morro Azul é o nome de uma antiga fazenda de café de Limeira, no Estado de São Paulo e que, por ter hospedado duas vezes Pedro II, é conhecida na região como a Fazenda do Imperador e, mais precisamente, como Casa de D. Pedro. Oswald de Andrade dedicou um poema à fazenda, com o título Morro Azul, em que um dos versos diz: "Na casa que ainda espera o Imperador” (ANDRADE, O., 1990, p. 93).

Consilva, o inimigo dos Esteves, por seu turno, é um representante do latifúndio expansionista brasileiro; mas, adicionalmente, pode também ser considerado um representante do Exército; o nome "Consilva”, etimologicamente "companheiro de Silva”, pode ser uma referência a Luís Alves de Lima e Silva, o Duque de Caxias. Embora este fosse exemplo de conservadorismo e um dos construtores da ordem monárquica, o conflito entre Afonsão e o major Consilva pode ser entendido como uma alusão ao conflito do imperador com as forças que o derrubaram no golpe militar de 15 de novembro, em cujas fileiras se encontravam fazendeiros escravistas inconformados, republicanos e o Exército - do qual o Duque é patrono. E a morte natural de Afonsão representaria a morte pacífica do Império.

O conflito entre Nhô Augusto e o major Consilva é o prolongamento do conflito vivido entre Afonsão e o major. Nhô Augusto vive à sombra do pai e por ele veste luto 
saudosista. Não assume a responsabilidade de cuidar dos bens que herdou; pelo contrário, dilapida-os. Dionóra, em discurso estranho para uma personagem feminina de família patriarcal - pois de forte conteúdo político e econômico que muito se parece com a descrição da crítica situação econômica brasileira depois do Império -, mostra aflição pela falta de perspectivas de reversão da situação econômica do marido:

Agora, com a morte do coronel Afonsão, tudo piorara, ainda mais. Nem pensar. Mais estúrdio, estouvado e sem regra, estava ficando Nhô Augusto. E com dívidas enormes, política do lado que perde, falta de crédito, as terras no desmando, as fazendas escritas por paga, e tudo de fazer ânsia por diante, sem portas, como parede branca .(p. 329)

Consilva compra os serviços dos jagunços antes a soldo de Nhô Augusto, derrota seu inimigo e amplia suas propriedades e, dessa forma, confirma sua posição de fazendeiro bem-sucedido e de predomínio das forças agrárias organizadas que dominaram a República Velha.

Podemos agora voltar às questões que levantamos sobre a distinção entre Matraga e as outras divindades e de como a "saga de Matraga” está incorporada à idéia de que Sagarana é uma representação do Brasil.

Matraga carrega os atributos que deveriam ser esperados em uma entidade mitológica brasileira. Como na sociedade brasileira, ele funde um conjunto de várias religiões, é ambíguo, promotor mais da violência e da desordem do que da paz e da ordem. O apocalipse da saga nórdica é marcado pela fúria dos contendores, enquanto o apocalipse da saga brasileira, o embate que fecha o conto, é a alegoria da violência cordial, alegre, prazerosa para o indivíduo, mesmo que o conduza à morte - como no caso de Cassiano, de Duelo -, ou que talvez lhe seja mais prazerosa justamente por conduzi-lo à morte. É a violência pela violência, inerente às relações sociais no Brasil presentes em Sagarana. Ao tentar instalar a justiça com o emprego da violência, Matraga atua como seria esperado de uma entidade divina que norteasse e determinasse a vida e o comportamento das personagens de Sagarana.

Como vimos na introdução deste trabalho, a narrativa de A hora e vez de Augusto Matraga se encerra na revolução de 30. A luta final entre Matraga e Joãozinho Bem-Bem é a alegoria do encerramento de um período histórico que principiou com a proclamação da República e terminou com o movimento que representou a tentativa de 
desalojamento das oligarquias que dominavam a República Velha e a sua substituição por um forte poder centralizado e autoritário. ${ }^{46}$

O final do conto é o autêntico Crepúsculo dos Deuses à brasileira, sinônimo do apocalipse de que falamos. É o final ambíguo de uma obra escrita no período getulista, sendo possível interpretá-lo de várias formas contraditórias, dependendo de como entendermos o desenvolvimento da situação política e social do Brasil nos anos que antecederam a proclamação da República e nos que se seguiram à revolução, situandose, portanto, fora dos limites temporais do texto. Demarcamos três possibilidades de interpretação do fechamento de A hora e vez de Augusto Matraga:

A primeira contém a esperança de início de uma nova etapa da vida nacional patrocinada pelo poder centralizado da Nova República, posição que equivaleria à adesão ao regime getulista e à identificação com o pensamento dos ideólogos do autoritarismo centralizado, como “Oliveira Viana e Alberto Torres, que propunham uma visão hierárquica e autoritária da sociedade, justamente a que Sérgio Buarque de Holanda criticava em Raízes do Brasil.” (CANDIDO apud HOLANDA, 1999, p. 11); a última frase de Matraga — “Fala com a Dionóra que está tudo em ordem!” — pode ser entendida como uma alusão à “ordem” que então principiava, quando comparada à desordem da Primeira República.

A segundo traz a noção de que a revolução de 30 meramente substituiu a violência desmedida privada pela violência desmedida oficial; esta possibilidade, que pode encerrar uma crítica à República e sugere certa “nostalgia monárquica”, é vislumbrada nas palavras de Mimita, a criança que sente vergonha dos desmandos do pai e quer dele afastar-se e afastar a mãe — “- Eu gosto, minha mãe, de voltar para o Morro Azul...” (p. 328) —, e nas palavras de Dionóra já mencionadas: “Agora, com a morte do coronel Afonsão, tudo piorara, ainda mais.” Esta alternativa de interpretação é a defendida por Roncari, que assim discorre sobre uma terceira camada presente nos textos do autor (as outras duas seriam a empírica e a culta):

Ela alegorizava a história da vida político-institucional de nossa primeira experiência republicana e numa perspectiva que poderíamos considerar conservadora. Como crítica das instabilidades do novo regime, ela participava também da nostalgia da “ordem imperial”, desencadeada pelas crises políticas e institucionais que se sucediam, e que se acentuou com as comemorações do centenário de nascimento de Dom Pedro II. Desse modo, o “conservador” aqui, se manifestava não como uma defesa da ordem, mas

\footnotetext{
${ }^{46}$ Sobre o assunto e sua importância na obra de Rosa, ver $O$ cão do sertão, de Roncari, onde pode ser lido interessante depoimento do general Góes Monteiro a Lourival Coutinho (RONCARI, 2007, p. 23-5).
} 
como uma crítica dela e por uma outra ordem, restauradora do pai tutelar ou da autoridade que se havia perdido com a República. (RONCARI, 2004, p. 18-9).

Sob essa perspectiva, Sagarana evidenciaria a desordem social da República quando comparada ao Império. Analisando o capítulo Nossa revolução, de Raízes do Brasil, Antonio Candido refere-se ao impasse criado pela permanência, na República, da estrutura política colonial:

Os modelos políticos do passado continuam como sobrevivência, pois antes se adequavam à estrutura rural e agora não encontram apoio na base econômica. Daí o aspecto relativamente harmonioso do Império, ao contrário da República, que não possui um substrato íntegro, como era o de tipo colonial. Cria-se então um impasse, que é resolvido pela mera substituição dos governantes ou pela confecção de leis formalmente perfeitas. Oscilando entre um extremo e outro, tendemos de maneira contraditória para uma organização administrativa ideal, que deveria funcionar automaticamente pela virtude impessoal da lei, e para o mais extremo personalismo, que a desfaz a cada passo. (CANDIDO in HOLANDA, 1999, p. 18-9).

Sezão reforça essa possibilidade de interpretação, porque os fatos ali narrados se estendem para a Nova República, como lemos em Minha gente, em uma passagem em que o narrador fala da memória e da capacidade de Santana de estabelecer relações de causa e efeito, fazendo " por exemplo, do 27 de junho de 1932, o ontem de 10 de maio de 1936 e o ante-ontem de não sei que dia.” (ROSA, J. G., 1937, p. 142). O fato de Rosa ter restrito a narrativa de Sagarana ao período da República Velha pode ter origem em seu entendimento dos acontecimentos políticos internacionais e brasileiros a partir de 1937 - dentre os quais a instituição do Estado Novo.

A terceira atribui a desordem propagada em todo o Sagarana à persistência da velha estrutura colonial, como um enclave anacrônico na República, o que não exclui a possibilidade de supor que, independentemente do momento histórico, estamos destinados a não ultrapassar o estado de violência que a prevalência do poder privado sobre o do Estado, como ocorreu na República Velha, simplesmente acentuou - o que equivaleria a endossar as palavras de Raízes do Brasil já citadas: “A sociedade foi mal formada nesta terra desde as suas raízes.” (HOLANDA, 1999, p. 181).

Como pudemos ver, a "saga de Matraga” tem vários sentidos. O primeiro, mais visível, relata a vida de um homem violento e poderoso que passa por um processo de conversão cristã, comporta-se como um santo asceta e sacrifica a própria vida para combater a injustiça e a violência. No sentido religioso mais profundo, é a vida de uma entidade mitológica que repete a experiência de um grande número de santos, líderes 
religiosos e divindades, cuja origem pode ser encontrada no mito da fertilidade. No sentido alegórico, ela sintetiza a violência e a desordem das relações na sociedade brasileira da Primeira República.

Muito apropriadamente, na página 365 da $5^{a}$ edição de Sagarana, após a frase que encerra A hora e vez de Augusto Matraga, há uma ilustração de Poty - em cuja parte superior há a figura da Esfinge com chapéu de cangaceiro e, na parte inferior, uma ampulheta - que parece lançar o desafio continuamente vivido pelo leitor do conto e de todo o livro: decifra-me ou devoro-te.

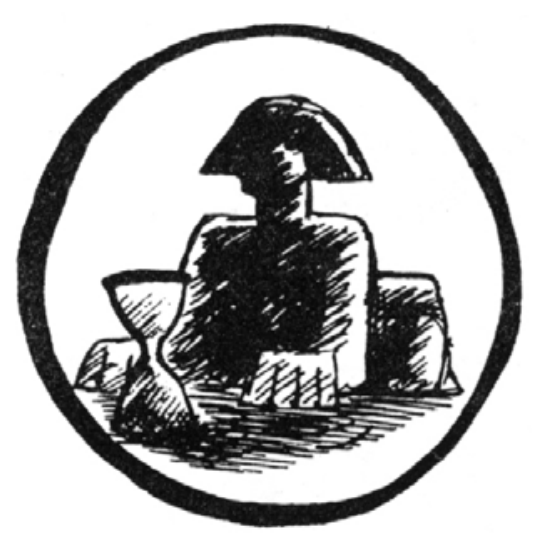




\section{CONCLUSÃO}

Do que foi exposto neste trabalho, pode-se concluir que Sagarana é uma obra coesa com respeito a vários aspectos: questões formais, época historicamente determinada, ambiente físico e social determinado e, principalmente, abordagem de tópicos como violência, poder, família, religião, melancolia, raças e outros. No tratamento internamente coerente dado a esses tópicos e na presença latente das teses de Retrato do Brasil de Paulo Prado, de Populações meridionais do Brasil, de Instituições políticas brasileiras e do pensamento de Oliveira Vianna de modo geral, de Casa grande \& senzala, de Gilberto Freyre e, principalmente, de Raízes do Brasil, de Sérgio Buarque de Holanda - obras que, de uma ou de outra forma, abordaram os tópicos acima referidos -, reside a representação do Brasil da Primeira República que dá sentido global à obra. Como o tratamento de tais tópicos não se encerra em cada conto, mas, pelo contrário, vai sendo gradualmente montado ao longo da obra, esse sentido nuclear só pôde ser plenamente captado por uma leitura extensiva do livro no seu conjunto.

A representação, em Sagarana, de um período histórico brasileiro de enorme desordem e violência e de desmesurado poder privado traz implícita a noção que pode ser demarcada a partir das idéias de Hobbes e Freud, qual seja, a de que a criação de uma sociedade civilizada (segundo conceito de Francis Wolf) só se torna exeqüível com instituições fortes o suficiente para patrocinar e supervisar um contrato social capaz de manter sob controle os impulsos naturalmente destrutivos dos seres humanos - estejam estes na situação de comandados ou na de comandantes. Essa interpretação pode ou não significar conformação ideológica com o regime autoritário de Getúlio Vargas, como vimos na análise de A hora e vez de Augusto Matraga.

Pudemos observar neste trabalho que, de um conto para outro ou dentro do mesmo conto, o diálogo implícito entre autor, narrador e personagens apresenta ampla faixa de variação, indo, nos casos extremos, de aproximação e identificação ao de afastamento e oposição. Procuramos mostrar nas análises dos contos que racismo e sincretismo religioso são os encontradiços na sociedade brasileira e que não existem elementos textuais para atribuí-los ao autor; tal afirmativa encontra respaldo na totalidade do livro. A menção das categorias aristotélicas de indivíduos presente em vários contos poderia, contudo, sugerir uma forma de classificação social preconizada diretamente pelo autor. O que ocorre, no entanto, é que tal classificação faz parte da visão sistêmica de um Estado civilizado, porque guarda relação com os conceitos de 
civilização de Freud, Hobbes e outros, enfim, com todo um corpo de reflexões do pensamento ocidental, voltado para a compreensão dos nexos existentes entre instintos do homem, civilização e barbárie. Portanto, a classificação aristotélica não anda à margem da obra como elemento estranho, mas serve para apontar uma concepção sobre Estado civilizado. Esse conceito de Estado é o que serve de guia para uma apreciação final do estágio do processo civilizador brasileiro representado no livro; dessa forma, as noções do autor implícito foram detectadas no livro e não externamente a ele e serviram para reforçar nossa interpretação da obra.

Um aspecto significativo para a interpretação do livro decorre da seguinte afirmação que trataremos de contestar: como Sagarana é ambientado no sertão, ele é, na verdade, um retrato do meio rural brasileiro; logo, uma interpretação como a que estamos propondo não poderia ser generalizada para toda a nação. Para reforçar essa afirmação, podem ser mencionados os casos em que é mostrado o desencontro entre a vida de personagens da cidade no meio rural e de personagens do meio rural na cidade: Lalino, de A volta do marido pródigo, tem sucesso político em sua terra de origem, mas fracassa lamentavelmente no Rio de Janeiro; Turíbio Todo, de Duelo, considerado um “vagabundo” em sua cidade no sertão, dá-se bem em centro urbano como Guaxupé, onde se supõe que só poderia vencer pelo trabalho árduo; o Primo visitante, de Minha gente, da cidade grande, tenta conquistar Maria Irma, mas esta o empurra para Armanda, também citadina.

Para contestar esses argumentos, basta lembrar que é no ambiente coronelístico em que o livro se desenrola que se situa a fonte de poder político e econômico da Primeira República. Victor Nunes Leal, em Coronelismo, enxada e voto, refere-se ao fato de, na política brasileira, o poder dos municípios advir de um sistema de favores recíprocos entre a política estadual e a local. No prefácio do livro, Barbosa Lima Sobrinho menciona Alberto Torres para destacar o poder dos municípios na política brasileira durante a Primeira República. Segundo Torres, a pirâmide das organizações partidárias tinha sua base na politicagem local, sendo o poder político, em relação a esta, enfraquecido no Estado e ainda mais tênue no âmbito do governo federal. (LEAL, 1978, p. XIV). De forma mais ou menos similar, Raymundo Faoro descreve o exercício do poder do coronel (FAORO, 1975, p. 622), e Nelson Werneck Sodré escreve sobre a posição proeminente, no exercício das funções políticas e administrativas, do meio rural em relação aos núcleos urbanos durante o período das oligarquias republicanas (SODRÉ, s/d. p. 192). Raízes do Brasil menciona a proeminência, no período colonial, 
do meio rural: "os centros urbanos brasileiros nunca deixaram de se ressentir fortemente da ditadura dos domínios rurais” (HOLANDA, 1999, p. 89). Por outro lado, a incompatibilidade entre a forma de vida na cidade e a do campo, mostrada nos exemplos acima, não invalida a noção de que Sagarana é uma representação do Brasil e não do sertão; pelo contrário, ela leva à constatação da existência de um hiato entre a cidade e o meio rural, que em última instância é a tradução de uma divisão profunda da sociedade. Tal divisão tem, na obra, raízes num poder privado forte, partilhado entre os membros da classe dos grandes proprietários rurais, poder que, justamente por seu caráter privado, impede a penetração do poder central do Estado.

É claro que Sagarana sempre propiciará muitas outras leituras sociais, além da que estamos propondo neste trabalho. Por outro lado, uma interpretação estritamente espiritualista da obra, de forma a entendê-la como o relato de uma cadeia de eventos com a finalidade de apresentar alguma tese ou abrir ampla discussão sobre temas e clássicos da literatura e do pensamento universais, com foco em indagações filosóficas, religiosas, etc. - que alguns críticos, amparados nas declarações do próprio autor ${ }^{47}$, têm apontado como determinantes do sentido da obra -, explicaria satisfatoriamente vários aspectos do texto, mas seria insuficiente para justificar a presença dos muitos tópicos relacionados com a sociedade brasileira - violência, poder privado, estrutura familiar, mistura de religiões e crenças, confusão entre o público e o privado, alusões a fatos e personagens políticos, inoperância ou mesmo ausência de instituições oficiais, e muitos outros -, além de deixar de dar uma razão plausível para o fato de se ter todo um entrecho situado num período da história do Brasil claramente especificado. Por outro lado, dar à obra uma interpretação social, como fizemos nas nossas análises dos contos, funciona como uma espécie de navalha de Okham, porque tudo fica explicado inclusive os tópicos inerentes à leitura espiritualista, como vimos.

Uma outra questão que poderia ser levantada nestas conclusões é se Guimarães Rosa teve a intenção manifesta de fazer uma representação do Brasil pela abordagem de tópicos como família, religião, política, raças e outros. Essa questão tem relevância limitada, porque nossa análise se prendeu prioritariamente ao texto e não se ocupou de especificar e muito menos de tomar como dado de entrada a ideologia política do autor (por outro lado, pensamos que este trabalho poderá abrir caminhos para futuras e

\footnotetext{
${ }^{47}$ Rosa forneceu a Bizzarri uma pontuação do que deve ser observado em seus escritos: a) cenário e realidade sertaneja: 1 ponto; b) enredo: 2 pontos; c) poesia: 3 pontos; d) valor metafísico-religioso: 4 pontos (ROSA, J. G., 1981, p. 58)
} 
eventuais formulações de hipóteses sobre essa ideologia, para aqueles que o desejarem,); de qualquer forma, a questão é interessante porque uma resposta positiva reforçaria nossa interpretação da obra. Acreditamos que a resposta a essa questão é dada no próprio texto: é difícil presumir que uma obra que no seu conjunto trata com tanta coerência interna daqueles tópicos sociais seja fruto do acaso ou do inconsciente do autor. A concordância entre os pontos de vista sobre o Brasil passíveis de ser depreendidos em Sagarana e as teses do "pensamento social brasileiro" é muito forte para ser considerada meramente fortuita. Pensamos que Rosa pretendeu defender aqui a noção, endossada por Graça Aranha, de que explicar o Brasil por meio de um ensaio científico seria incorrer numa discussão racional pouco profunda, em vista da enorme complexidade do assunto - como, nas próprias palavras de Rosa transcritas na análise de São Marcos, fez Gilberto Freyre. Rosa aplicou um método eficaz de representação da realidade brasileira ao optar pela ficção e por sua configuração em contos interpretáveis de forma sistêmica.

Antonio Candido escreveu que "as melhores expressões do pensamento e da sensibilidade têm quase sempre assumido, no Brasil, forma literária”. Sagarana é um livro exemplar para confirmar essas palavras de nosso crítico maior. 


\section{REFERÊNCIAS BIBLIOGRÁFICAS}

\section{OBRAS DE GUIMARÃES ROSA}

ROSA, J. Guimarães. Sagarana. 3a . ed. Rio de Janeiro: José Olympio, 1951.

ROSA, J. Guimarães. Sagarana. 5a. ed. Rio de Janeiro: José Olympio, 1958.

ROSA, J. Guimarães. Sagarana. 15a . ed. Rio de Janeiro: José Olympio, 1971.

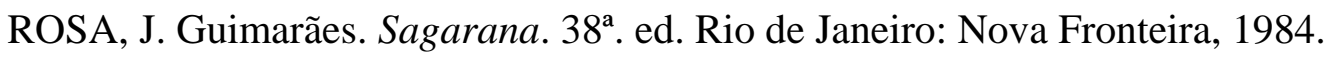

ROSA, J. Guimarães, sob pseudônimo de "Viator”. Sezão. IEB-USP: Instituto de Estudos Brasileiros da USP, 1937.

ROSA, J. Guimarães. Grande Sertão: Veredas. Rio de Janeiro: José Olympio, 1956.

ROSA, J. Guimarães. Correspondência com seu tradutor italiano Edoardo Bizzarri. $2^{a}$. ed. São Paulo: T. A. Queiroz, editor - Instituto Cultural Ítalo-Brasileiro, 1981.

IEB-USP. Correspondência de Guimarães Rosa com a tradutora americana Harriet de Onís e com o tradutor alemão Curt Meyer-Clason. Série: Correspondência, Sub-série: Correspondência com tradutores.

IEB-USP. Estudos para obra de Guimarães Rosa.

\section{OBRAS DE OUTROS AUTORES}

ABBAGNANO, Nicola. Dicionário de filosofia. São Paulo: Martins Fontes, 2000.

AGUIAR E SILVA, Vítor Manuel. Teoria da literatura. $2^{\mathrm{a}}$. Ed. Coimbra, Portugal. Livraria Almedina: 1968.

ALIGHIERI, Dante. La Divina Commedia. 21ª . Ed. Milano: Ulrico Hoepli: 1987.

ALIGHIERI, Dante. A Divina Comédia. Tradução de José Pedro Xavier Pinheiro, São Paulo: Edigraf, 1946.

ANDRADE, Mário de. Pequena história da música. 5a. Ed. São Paulo: Martins Editora, 1958.

ANDRADE, Mário de. Aspectos da literatura brasileira. 6a. Ed. Belo Horizonte: Itatiaia, 2002.

ANDRADE, Oswald de. Pau-Brasil. São Paulo: Editora Globo, 1990.

ARANHA, Graça. A Esthetica da Vida. Rio de Janeiro: Garnier, 1921.

ARAÚJO, Heloisa Vilhena de. O roteiro de Deus - Dois Estudos sobre Guimarães Rosa. São Paulo: Editora Mandarim, 1996. 
ARISTÓTELES. Ética a Nicômano in Os Pensadores vol. IV São Paulo: Abril Cultural, 1973.

ARISTÓTELES. Poética in Os Pensadores vol. IV São Paulo: Abril Cultural, 1973.

AUERBACH, Eric. Mimesis. 4ª Ed., São Paulo: Perspectiva, 2001.

AZEVEDO, Carmen Lúcia de; CAMARGOS, Márcia; SACCHETTA, Vladimir. Monteiro Lobato, furacão na Botocúndia. São Paulo: Editora Senac, 1997.

BACON, Francis. Novum Organum in Os Pensadores vol. XIII. São Paulo: Abril Cultural, 1973.

BARBOSA, Rui. Discursos, orações e conferências. 4ª Ed. São Paulo: Editora Iracema, 1972.

BASTOS, Élide Rugai e MORAES, João Quartim, orgs. O pensamento de Oliveira Vianna. Campinas: Editora da Unicamp, 1993.

BAUMAN, Zygmunt.. Modernidade e ambivalência. Rio de Janeiro: Jorge Zahar, 1999. BENJAMIN, Walter. O narrador in Os Pensadores vol. XLVIII. São Paulo: Abril Cultural, 1975.

BENEDETTI, Nildo Maximo. As múltiplas faces de A hora e vez de Augusto Matraga e suas duas traduções italianas. São Paulo. Dissertação de mestrado na FFLCH - USP, 2003.

BÍBLIA SAGRADA. tradução de Padre Antônio Pereira de Figueiredo, Rio de Janeiro:Ed. Brasa 1964.

BOLLE, Willi. Grandesertão. br. São Paulo: Editora 34, 2004.

BOOTH, Wayne C. A Retórica da ficção. Lisboa, Portugal: Col. Artes e Latras/Arcádia, 1980

BORGES, Jorge Luis. Nueve ensayos dantescos. Madri: Seleciones Austral, 1982.

BUENO, Luís. Uma história do romance de 30. São Paulo: Edusp / Unicamp, 2006.

BULFINCH, Thomas. O livro de ouro da mitologia. Rio de Janeiro: Edições de Ouro, 1957.

BURKERT, Walter. Religião grega na época clássica e arcaica. Lisboa: Fundação

Calouste Gulbenkian, 1993

CAMPOS, Aguinaldo Aparecido. Passagens bíblicas em Sagarana, de João Guimarães Rosa. São Paulo: dissertação de mestrado na FFLCH-USP, 2000.

CANDIDO, Antonio. Formação da literatura brasileira. Beço Horizonte - Rio de Janeiro: Itatiaia, 2000. 
CANDIDO, Antonio. Literatura e sociedade. 8a. Ed. São Paulo: T. A. Queiroz Editor, 2002.

CANDIDO, Antonio. A educação pela noite. São Paulo: Ática, 1987.

CANDIDO, Antonio. CASTELLO, José Aderaldo. Presença da literatura Brasileira: Modernismo. 9a. Ed. São Paulo: Difel, 1983.

CARDOSO, Lúcio. Maleita. Rio de Janeiro: Civilização Brasileira, 2005.

CARPEAUX, Otto Maria. Alceu Amoroso Lima. Rio de Janeiro: Edições Graal, 1978.

CARVALHO, Cleuza Martins de. O que revelam os manuscritos de João Guimarães Rosa. São Paulo: Revista do IEB No. 41, 1996 p. 191-96

CASCUDO, Luís da Câmara. Dicionário do folclore brasileiro. Rio de Janeiro: Edições de Ouro, 1969.

CASIRIER, Ernst. A filosofia do Iluminismo. Campinas, SP: Unicamp, 1997.

CHAUÍ, Marilena. Convite à filosofia. 12 ed. São Paulo: Editora Ática, 2001.

CHOMSKY, Noam. Poder e terrorismo. Rio de Janeiro: Editora Record, 2005.

CLASTRES, Pierre. Arqueologia da violência. São Paulo: Cosac \& Naify, 2004.

CORNFORD, Francis Macdonald. Principium Sapientiae, origem do pensamento

filosófico grego. Lisboa: Fundação Calouste Gulbenkian, 1952.

COSTA, Ana Luiza Martins. Rosa, ledor de Homero. São Paulo: Revista USP dez/fev 1997-98, ps. 47-62.

COUTINHO, Afrânio. Guimarães Rosa (coletânea de textos dirigida por Afrânio Coutinho). Rio de Janeiro: Civilização Brasileira, 1991.

CULLER, Jonathan. Teoria literária. São Paulo: Beca Produções Culturais, 1999.

CUNHA, Euclydes da. Os sertões. 15a. Ed.. Rio de Janeiro: Francisco Alves, 1940.

DIEL, Paul. O simbolismo na mitologia grega. São Paulo: Attar Editorial, 1991.

DOUGLAS, J. D. O novo dicionário da Bíblia. 2 ed. São Paulo: Edições Vida Nova, 1995.

DURANT, Will. A idade da fé. Vol IV da História da civilização, 2ª ed. Rio de Janeiro:

Record, s/d

EDUARDO, Dom Frei. Adoremus, Manual de orações e exercícios piedosos. 29 ed.

Salvador: Ed. Mensageiro da Fé, 1959.

ELIADE, Mircea. Mefistófeles e o Andrógino. São Paulo: Martins Fontes, 1991.

ELIADE, Mircea. Tratado de história das religiões, São Paulo: Martins Fontes, 2002.

FACÓ, Rui. Cangaceiros e fanáticos. 5 ed. Rio de Janeiro: Civilização Brasileira, 1978. 
FAORO, Raymundo. Os donos do poder. Porto Alegre / São Paulo: Editora Globo / Editora da USP, 1975.

FAUSTO, Boris. História do Brasil. São Paulo: Edusp, 1994.

FINAZZI-AGRÓ, Ettore. Um lugar do tamanho do mundo. Belo Horizonte: Editora UFMG, 2001.

FRANCO, Maria Sylvia de Carvalho. A vontade santa. in Trans/form/ação, Revista de Filosofia da Faculdade Filosofia, Ciências e Letras de Assis No. 2. Assis, SP, 1975.

FRANCO, Maria Sylvia de Carvalho. Homens livres na ordem escravocrata, $4^{\mathrm{a}}$. Ed. São Paulo: Unesp, 1997.

FREUD, Sigmund. Edição Standard brasileira das obras completas de Sigmund Freud. Rio de Janeiro: Imago, datas diversas (o número do volume e o ano da edição brasileira estão assinalados no texto deste trabalho no qual é feita a menção bibliográfica).

FREYRE, Gilberto. Casa Grande \& Senzala. 26 ed. Recife: Editora Record, 1989.

GALVÃO, Walnice Nogueira. Mitológica Rosiana. São Paulo: Ática, 1978.

GALVÃO, Walnice Nogueira. As formas do falso. 2ª . Ed. Perspectiva: São Paulo, 1986.

GARBUGLIO, José Carlos. Rosa em dois tempos. São Paulo: Nankin, 2005.

GASPAR, Eneida D. Guia de religiões populares do Brasil. Rio de Janeiro: Pallas, 2004.

GIRARD, René. A violência e o sagrado. 2 ed. São Paulo: Ed. UNESP, 1998.

GOETHE, Johann Wolfgang von. Fausto. 4 ed. tradução de Jenny Klabin Segall. Belo Horizonte: Editora Itatiaia, 1997.

HAUSER, Arnold. História social da arte e da literatura. São Paulo: Martins Fontes, 2000.

HOBBES, Thomas. Leviatã ou Matéria, forma e poder de um Estado eclesiástico e civil. Vol. 14 da coleção Os pensadores. São Paulo: Abril, 1974.

HOLANDA, Sérgio Buarque de. Raízes do Brasil, 26ª ed. São Paulo: Companhia das Letras, 1999.

HOLANDA, Sérgio Buarque de. Visão do Paraíso. 4a. ed., São Paulo: Editora Brasiliense, 1998.

HOMERO, Iliada. Tradução de Haroldo de Campos. São Paulo: Editora Mandarim, 2001.

HOMERO. Odisséia. Tradução de Carlos Alberto Nunes. 3 ed. São Paulo: Melhoramentos, s/d. 
HORKHEIMER, Max e ADORNO, Theodor W. Conceito de Iluminismo. in Os Pensadores vol. XLVIII. São Paulo: Abril Cultural, 1975.

HOUAISS, Antônio. Dicionário Eletrônico Houaiss. Rio de Janeiro: Objetiva, 2001. JOUVE, Vincent. A leitura. São Paulo: Ed. Unesp, 2002.

JUNG, Carl G. Interptação psicológica do dogma da Trindade. 2a . ed. Petrópolis: Vozes, 1983.

LEAL, Victor Nunes. Coronelismo, enxada e voto. 4a ${ }^{\mathrm{a}}$ ed. São Paulo: Editora AlfaOmega, 1978.

LIMA, Alceu Amoroso. Estudos literários. Rio de Janeiro: Aguilar Editora, 1966.

LOBATO, Monteiro. Urupês. 32a . Ed. São Paulo: Brasiliense, 1986.

MARTINS, Nilce Sant’Anna. O léxico de Guimarães Rosa. São Paulo: Edusp. 2001.

MATTOS, Sonia Heinrich de. Deuses e heróis na Edda poética e na Tetralogia de Wagner. Tese de Livre-docência apresentada na FFLCH-USP, 1959.

MELLO, Frederico Pernambucano de. 5a. Ed. São Paulo: A Girafa Editora Ltda, 2005.

MORAES, Eduardo Jardim de. A brasilidade modernista. Rio de Janeiro: Graal, 1978.

MORAES Walfrido Jagunços e heróis. 4 ed. Salvador: Empresa Gráfica da Bahia (PAC), 1991.

NIETZSCHE, Friedrich Wilhelm. A origem da tragédia. São Paulo: Moraes, s/d NOVAES, Adauto, org. Civilização e barbárie. São Paulo: Companhia das Letras, 2004.

NUNES, Benedito. A viagem in O dorso do tigre. São Paulo: Perspectiva, 1969.

OLIVEIRA, Franklin. A dança das letras. Rio de Janeiro: Topbooks, 1991.

OLIVER, Nelson. Todos os nomes do mundo. Rio de Janeiro: Ediouro, 2005.

OVÍDIO Nasone, Publio. Metamorfoses. São Paulo, Madras , 2003.

OVÍDIO Nasone, Publio. Amores. Milano, Mondadori, 1994.

PASSOS, Cleusa Rios P. Guimarães Rosa: do feminino e suas estórias. São Paulo: Hucitec, 2000.

PESSOA, Fernando. Obra poética. Rio de Janeiro: Nova Aguilar S.A., 1986.

POE, Edgar Alan. Poemas e ensaios. São Paulo: Editora Globo, 1999.

POIRION, D, Le poète et le prince. Genebra: Slatkine Reprints, 1978

PRADO JÚNIOR. Caio. Formação do Brasil contemporâneo. 23a . Ed. São Paulo: Editora Brasiliense, 1999.

PRADO JÚNIOR. Caio. História econômica do Brasil. 6a. Ed. São Paulo: Editora Brasiliense, 1961. 
PRADO, Paulo. Retrato do Brasil. 9a. Ed. São Paulo: Companhia das Letras, 1999. RIBEIRO, Renato Janine. A marca do Leviatã. São Paulo: 2a . Ed. Ateliê, 2003.

RICARDO, Cassiano. Martin Cererê. 22a . Ed. Rio de Janeiro: José Olympio, 2003. RONCARI, Luiz Dagobert de Aguirra. O Brasil de Rosa. São Paulo: UNESP, 2004. RONCARI, Luiz Dagobert de Aguirra. O cão do sertão. São Paulo: UNESP, 2007. ROSA, Vilma Guimarães, Relembramentos: João Guimarães Rosa, meu pai. 2 ed. Rio de Janeiro: Nova Fronteira, 1999.

SANTOS, Sebastião Dodel dos. Dicionário ilustrado de Maçonaria (sem indicação de cidade de impressão e de editora). 1983.

SCHWARZ, Roberto. Grande sertão e Dr Faustus in Sereia e o desconfiado. 2 ed. Rio de Janeiro: Paz e Terra, 1981.

SCHWARZ, Roberto. Ao vencedor as batatas. 5a . ed. São Paulo: Duas Cidade, 2000.

SMITH, Huston. As religiões do mundo. São Paulo: Cultrix, s/d.

SODRÉ, NELSON WERNECK. O que se deve ler para conhecer o Brasil. São Paulo: Círculo do Livro, s/d.

STARLING, Heloísa. Lembranças do Brasil. Rio de Janeiro: Editora Revan, 1999.

STURLUSON, Sborri. Edda em prosa. Rio de Janeiro: Numen Editora, 1993.

TODOROV, Tzvetan. Estruturalismo e poética. São Paulo: Cultrix, 1976.

VERLANGHIERI, Iná Valéria Rodrigues. J. Guimarães Rosa - Correspondência inédita com a tradutora morte-americana Harriet de Onís. Dissertação de mestrado na UNESP de Araraquara, 1993

VERNANT, Jean-Pierre, NAQUET, Pierre Vidal. Mito e tragédia na Grécia antiga. São Paulo: Perspeciva, 1999.

VIANNA, Oliveira. Instituições políticas brasileiras, Niterói, Eduff, 1987a.

VIANNA, Oliveira. Populações meridionais do Brasil, vols. 1 e 2. Belo Horizonte: Itatiaia, 1987b.

VIANNA, Oliveira. Ensaios Inéditos. Campinas, SP: Unicamp, 1991.

VIEIRA, Padre Antônio. Obras completas - Sermões. Porto, Portugal: Lello e Irmãos Editores, 1959.

VIRGÍlLIO, Públio. Obras de Virgílo. Lisboa: Temas e debates, 1999. 